\title{
A CONSTRUÇÃO DE UM PARADIGMA EXISTENCIAL PARA A PROMOÇÃO DA SAÚDE JUNTO A ADOLESCENTES NO QUE RESPETTA AO USO E ABUSO DE SUBSTÂNCIAS PSICOATIVAS
}

\section{ROBERTO CACURO}

Tese apresentada na área de concentração de Pratica de Saúde Pública da Faculdade de Saúde Pública da Universidade de São Paulo para obtenção do Grau de Doutor.

Área de concentração: Prática de Saúde Pública

ORIENTADORA: PROFa . DR ${ }^{a}$. ARACY W. P. SPINOLA

São Paulo 2004 
Autorizo, exclusivamente para fins acadêmicos e científicos, a reproduçáo total ou parcial desta tese por processos fotocopiadores.

Assinatura:

Data:

$$
44945 / 2004 \text { doc }
$$




\section{AGRADECIMENTOS}

A Profa. Dra. Aracy W. P. Spinola por haver possibilitado a consecução deste trabalho aceitando-me gentilmente como seu orientando.

Às pessoas do Reino da Garotada, Rosely, Gláucia, Gisele, Elisete, Edem e todos os monitores, com as quais tenho o prazer de trabalhar nos projetos de promoção da saúde já há quatro anos. Em especial agradeço aos adolescentes do Reino, compreensivamente irrequietos e amorosos, às mães e pais do "Programa de Estruturação Familiar e Geração de Renda", aos quais atribuo grande valor por sua luta por uma vida melhor e em bem cuidar de seus filhos.

Ao Prof. Associado Fernando Lefevre e ao Prof. Dr. Alberto O. A. Reis, que teceram críticas positivas ao meu trabalho. À Profa Dra. Sofia Cornbluth que me prestou seu apoio valioso em momentos importantes.

À minha esposa Margarita M.G. Lamelo e meus filhos Marco, Gabriel e Amã, que, amorosos, tiveram suficiente paciência para permitir a intrusão deste esforço em nossa vida.

Ao meu amigo Sidnei Molina que dispôs-se a discutir comigo pontos importantes da tese.

Aos amigos Pablo Bursztein, Marcos Martinho, Ricardo Rizek e José J. Name, que em distintos momentos me ajudaram apresentando caminhos para o desenvolvimento dos temas que me preocupavam.

Aos meus amigos Barbara Schwair e Gustavo Sarraf, que compartilham comigo o trabalho no Reino da Garotada.

Às pessoas do grupo Girasol da Espanha que alimentaram minha prática e reflexões nos encontros que tivemos.

Às pessoas que, na FSP, dão suporte aos alunos de pósgraduação, por sua gentileza e apoio logístico eficaz. 


\section{RESUMO}

Cacuro R. Um paradigma existencial para a promoçāo da saúde junto a adolescentes no que respeita ao uso e abuso de substâncias psicoativas. São Paulo; 2004. [Tese de Doutorado - Faculdade de Saúde Pública da USP].

Com o suporte de uma prática de trabalho na clinica psicanalitica, e no campo com adolescentes em situação de vulnerabilidade social, refletimos em torrio da possibilidade da utilização de um novo paradigma "existencial" nos programas de promoção da saúde no que respeita a prevenção ao uso e abuso de substâncias psicoativas. Esse nome provém das bases teóricas que o conformam - a Psicanálise e a Fenomenologia, elaboradas no cenário onde qualquer teorização ganha sentido: a dimensão Ética das ações humanas. Essa caracterização designa também seu conteúdo, que concerne justamente o projeto existencial de indivíduos em seus aspectos manifestos, seu comportamento visivel/mensurável, e não manifestos/invisível, sua intenção. Através da noção de "paradigma existencial", desenhamos aspectos de um "lugar" para o qual acreditamos - nós, agentes dispostos a intermediar a passagem de adolescentes para uma vida adulta saudável devam eles ser encaminhados a ocupar na sociedade, em sua família, em sua individualidade. Isto nos levou à reflexão acerca do processo saúdedoença e de seu significado na perspectiva da educação para a saúde aplicada a adolescentes: o inaugurar de um processo de autonomização. Compreendido em termos filosóficos e psicanalíticos, o sentido que conferimos a esse processo configura-se na escolha consciente de um caminho em sua vida que se realiza através de uma certa 
disciplina livremente seguida, uma atitude que paulatinamente torna 0 individuo consciente de seus determinantes inconscientes, de seus condicionamentos - os quais, agora na forma de escolhas, ele se dispõe a infirmar ou confirmar. No caminho de tornar-ser, esse seria, na melhor das hipóteses, o marco referencial para a promoção de sua saúde. 


\section{SUMMARY}

Cacuro R. An existential paradigm to promote health in adolescents as far as the use and abuse of psychoactive substances are concerned. São Paulo 2004 [PhD thesis - School of Public Health - USP].

Based on psychoanalytical clinical experience as well as on field experience with adolescents in vulnerable social situations, we reflected upon the possibility of using a new "existential" paradigm in health programs as far as the use and abuse of psychoactive substances are concerned. This name results from the theoretical basis that make it up - Psychoanalysis and Phenomenology existing in a scenery where theorizing makes sense: the Ethical dimension in human actions. Additionally, these features show its contents which concern precisely the individuals' existential project in its manifest aspects, their visible/measurable behavior as well as their non manifest/invisible behavior, that is their intention. Through the concept of "existential paradigm", we design aspects of a "place" where we - agents who are willing to help adolescents to walk along the path leading to a healthy adult life - believe they shall be led to in society, in their families, in their individuality. This made us think not only about the health-illness process but also about its meaning as far as education for health applied to adolescents is concerned: setting up a process of autonomy. Considered in philosophical and psychoanalytical terms, the meaning given to this process is created according to a conscious. choice of a path in his life undertaken freely with a certain discipline. Gradually, this attitude makes the individual aware of his unconscious determinants, of his conditionings, which now in the form of choices, he is ready to deny or confirm. In the path of becomingbeing, this would be at best the reference landmark to promote his health. 


\section{INDICE}

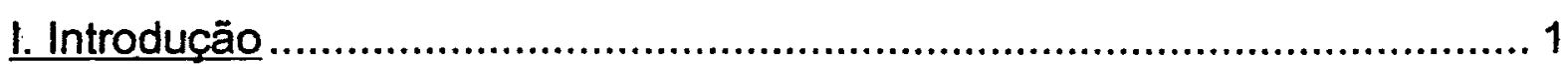

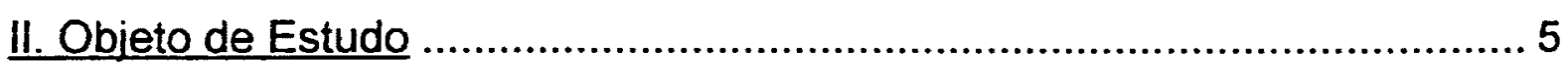

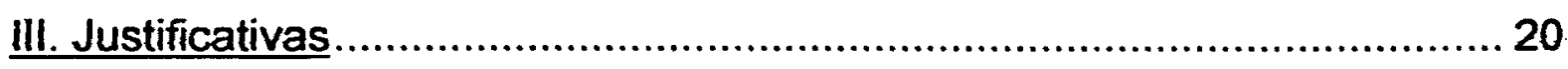

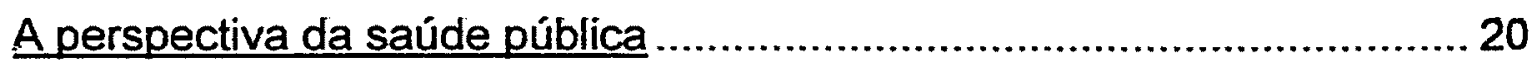

Quanto aos programas de promoção da saúde .................................... 20

Quanto ao uso e abuso de substâncias psicoativas........................... 21

A situação existente dentro de uma perspectiva qualitativa.................... 23

O adolescente, as drogas e a familia ................................................. 28

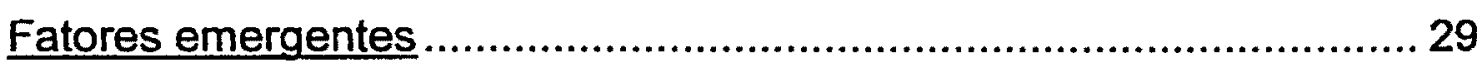

A perspectiva econômico-comencial ..................................................... 31

O papel da saúde pública ...................................................................... 32

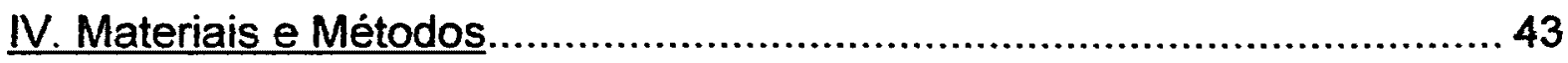

Descricäo do programa "Projeto de Vida" ..............................................44 44

Referencial Metodológico ................................................................45 45

Q Conhecimento na perspectiva fenomenológica................................... 48

Do ser do conhecimento ao conhecimento do Ser................................. 50

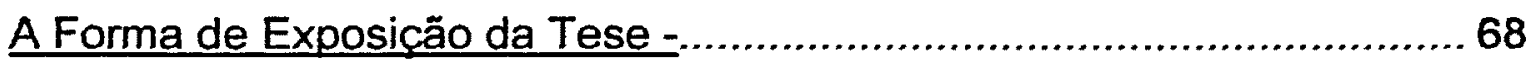

Do uso de determinadas formas literárias..........................................68

A alegoria do pêssego ................................................................ 77

V. Um Paradigma Existencial para a Promocão da Saúde.........................82 82

O sentido profundo da alienação na dimensão subjetiva .......................... 86

Principais pontos de referência para a construção de um "paradigma existencial" para a promoção da saúde na perspectiva da Psicanálise em

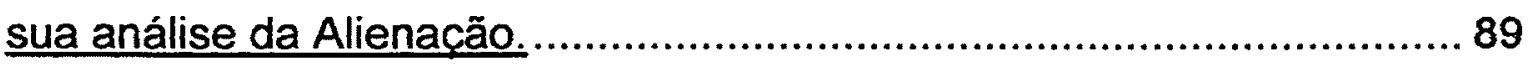

A dimensão social - coletiva do conflito alienação/heteronomia,

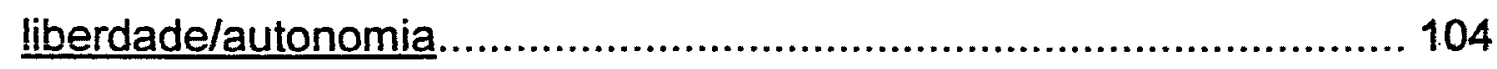

A situação da liberdade/autonomia .................................................. 108

A questāo da liberdade ou Do Significado Profundo da Educação para a Saúde .................................................................................... 110

Possibilidades e limites subjetivos do êxito de uma intervenção ........ 110 
VI. Terapeuein - A atitude terapêutica como prática amorosa eficaz ou Do Amor como prática terapêutica eficaz ................................................. 135

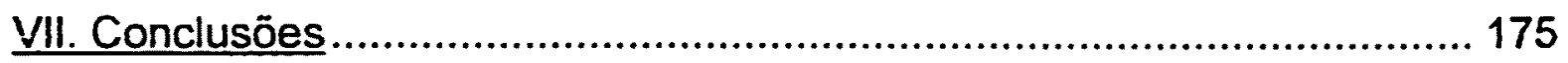

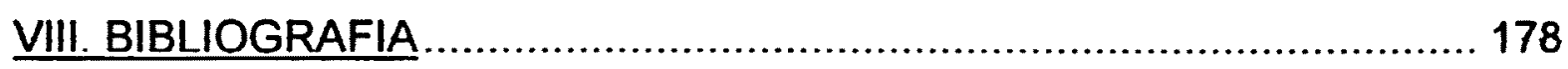

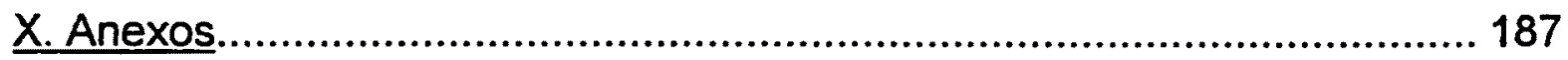

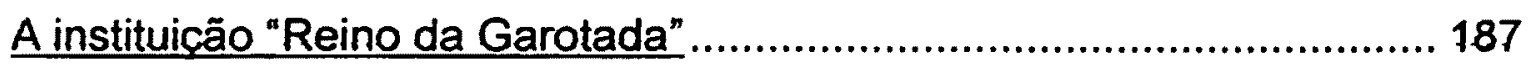

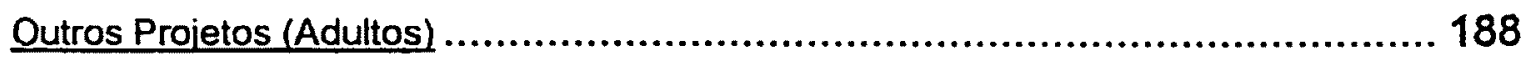

Intervencões realizadas no colégio Lycée Pasteur ............................... 192

Anexo - Contos de Ensinamento .................................................... 198 


\section{INTRODUÇÃO}

Este trabalho consiste em uma teorização acerca da promoçăo da saúde de adolescentes no que concerne a prevenção ao uso e abuso de substâncias psicoativas e suas vicissitudes; analisadas em termos das possibilidades de liberdade e de alienação que podem ser assumidas por cada individuo em seu caminho de desenvolvimento. Tratando-se de educar para a saúde, tornou-se imprescindivel conjugar a esse esforço uma reflexão ética de modo a produzir um sentido tal para o conceito de processo saúdedoença que, sem ser rígido, pudesse iluminar a prática indicando-lhe uma direção possível. Assim, alguns termos de referência comumente aceitos na área da promoção da saúde foram cotejados com aspectos da realidade que os concebeu, a antiguidade grega e o tratamento dado a ela pela filosofia platônica, fazendo transparecer seus harmônicos bem como suas dissonâncias - tanto em relação aos alvos a atingir quanto no que se refere aos meios para alcançá-los, discutidos em função de um ideal de realização humana. Nesse sentido, a Psicanálise e a Filosofia forneceram instrumentos que permitiram agregar novos termos de referência ao assunto amplificando o âmbito de sua discussão. Nos referimos, por exemplo, a conceitos como cidadania, emponderamento individual e coletivo, e/ou sensibilização da subjetividade individual, que fundamentam grande parte da prática educacional para a saúde, sendo percebidos como sinais de sucesso de uma intervenção - quando os indivíduos alvo provocam alteraçōes em suas vidas, como voltar a estudar, melhorar a qualidade de seus relacionamentos pessoais ou sentir-se mais à vontade para expressar seus pontos de vista na comunidade em que vivem ${ }^{1}$, permitindo o incremento de sua consciência em termos de direitos e deveres que the cabem assumir. Esta tese acresce a esse ideário visar, nas intervenções de promoção da saúde, a realização da autonomia do individuo tal como a compreendem a filosofia platônica e

\footnotetext{
${ }^{1}$ Encontramos consideraçóes como essas tecidas em diversos documentos da área da promoção da saúde. As idéias aqui colocadas são de Dias SMF. em "Avaliação dos projetos de educaçăo ambiental voltados para o gerencialmente dos resíduos sólidos urbanos.", São Paulo, Tese de Doutorado, FSP/USP, 2003, p, 249/250.
} 
fenomenológica além da Psicanálise, que contemplam o exercício do poder sobre a vida pública e seus desdobramentos concretos na vida pessoal, mediados, entretanto, pelo governo de si próprio - a instância do jdios cosmos, a alma individual.

Como ilustração e cenário dessa teorização funciona uma experiência que teve início em 1999 com o nome de "Programa de Ação.Preventiva" (PAP) ligado ao inicio das atividades da "Fundación Girasol" no Brasil que geraram as intervenções de prevenção primária junto a grupos adolescentes em uma empresa, primeiramente, e depois em escolas, onde, desde então, temos participado de projetos envolvendo alunos, pais e professores.

A instituição na qual essa experiência continua se desenvolvendo atingindo novos grupos adolescentes elou familias, chama-se "Reino da Garotada", em Poá/São Paulo, que atende cerca de 1000 crianças: e adolescentes abrangendo a creche ( 0 a 7 anos), centro de juventude ( 7 a 14 anos) e oficinas profissionalizantes (de 14 a 17 anos) (vide Anexo J). Até este momento (2004), o trabalho em Poá teve desdobramentos configurados em quatro grandes etapas, a saber:

$1^{a}$ Etapa (10 semestre 2000) - Envolvimento do pessoal do "Reino" no projeto, com 0 planejamento das ações respeitando a especificidade da instituição: perfil sócio-econômico e educacional/cultural dos professores e das familias usuárias, horários do pessoal envolvido na operação - pais que trabalham durante a semana, alunos com aulas em horários diurno ou vespertino - aplicação do PAP durante um semestre junto a alunos, pais e monitores.

\footnotetext{
${ }^{2}$ ONG em funcionamento na Espanha há 18 anos dedicada a açōes de prevenção e assistência à droga dependéncia. Estabelecida também no México e Argentina, seus termos de referéncia e modelo de funcionamento tem sido estudado e discutido por um grupo de pessoas dedicado a esse trabalho no Brasil.
} 
$2^{\text {a }}$ Etapa (2० semestre 2000) - Acompanhamento, durante um semestre, da aplicação do PAP pelos professores do "Reino" segundo seu próprio entendimento e características pessoais, fieis ao princípio norteador do PAP de ajudar os adolescentes a estruturar novos termos de referência que propiciem certo posicionamento consciente em relação ao uso, abuso e participação no circuito das drogas; com o aproveitamento de alguns dos instrumentos usados na $1^{a}$ etapa, mas sem a obediência rigorosa aos temas tratados então ou a sua seqüência.

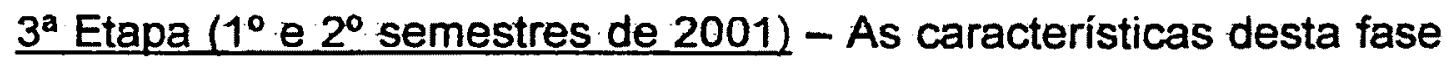
foram impostas, em grande parte, pela dificuldade de financiamento para replicação do PAP a outras turmas do "Reino". Houve; assim, o acompanhamento, durante um ano, dos problemas de violência acontecidos na região (que se agravaram) e seus reflexos no cotidiano da instituição, em sua relação com o circuito das drogas, através de reuniōes mensais envolvendo as coordenadorias e professores da instituiçäo. O esforço de prevenção dos professores nesse período continuou, com a extensão desse trabalho a todas as classes existentes dos cursos profissionalizantes (170 alunos), com o tema permeando todo o contato com os alunos durante as aulas, não havendo mais, portanto, um foco específico para a prevenção.

$4^{a}$ Etapa (2002/04) - Além da continuidade do trabalho com os adolescentes envolvendo o Centro de Juventude, consta de um esforço focado nas próprias famílias dos alunos do "Reino", viabilizada, no início, pelo programa "Geração de Renda", financiado pelo Estado, em curso desde - $2^{\circ}$ semestre de 2000 , agora assumido somente pela instituição. Neste "Programa de Estruturação Familiar e Geração de Renda", como passou a denominar-se, aproximadamente 30 familias com filhos na instituição, representadas por suas mães $(90 \%$ dos casos, sendo $50 \%$ de famílias monogâmicas) e pais ( $10 \%$ dos casos) escolhidas entre as mais necessitadas do ponto de vista material, recebem em torno de $\mathrm{R} \$ 100,00 / \mathrm{mês}$, passando, durante todo o período de ajuda (10 meses), por 
um treinamento que as capacite profissionaimente, nas áreas de panificação, costura, marcenaria, estofamento, etc. Um programa de oficinas acerca de temas associados às noçōes de cidadania participativa corre paralelo, tratando desde as relações familiares e seus desdobramentos, 0 exercicio da sexualidade, relaçōes com as drogas, etc., até a discussão acerca dos direitos e deveres próprios à cidadania, condiçōes para a criação da auto-estima, o estabelecimento de um plano de micro-negócios e noções de cooperação e cooperativismo, etc..

Com o "Programa de Estruturação Familiar e Geração de Renda", congregando a dimensão econômico-profissional (desenvolvimento de competências) a uma dimensão mais propriamente de educação para a saúde (compreendida, como veremos, enquanto desenvolvimento de atitudes respaldadas em uma intenção), espera-se produzir desdobramentos positivos no resgate da dignidade pessoal dos membros de cada família, desenvolvendo, além disso, um foco específico na reestruturação individual (em termos de construção da autonomia) e familiar e na qualidade da atenção, em algum grau sempre possivel, aos filhos - todas metas que se harmonizam com o conceito de promoçāo da saúde, como veremos a seguir, favorecendo, direta e indiretamente, a prevenção ao uso e abuso de substâncias psicoativas.

- conjunto dessas experiências mantém um papel relevante na construção desta Tese na medida em que alimentam a elaboração de todo o quadro teórico de referência funcionando assim; esperançosamente; como: uma espëcie de antídoto contra possiveis devaneios da elaboração intelectual. Dessa maneira, mesmo aceitando que "entre mim e ver há um grande sono", como diz Fernando Pessoa, procuro:

“... encostar as palavras à idéia

E não precisar dum corredor

Do pensamento para as palavras"

(Fernando Pessoa, Obra Poética, [765], p. 561 e [251], p. 225). 


\section{OBJETO DE ESTUDO}

Descrição e análise de um paradigma que chamamos de existencial, para o qual pleiteamos um lugar na condução de programas de promoção da saúde junto a adolescentes em situação de vulnerabilidade social - que proponham a escolha e adoção de condutas sadias em lugar do uso e abuso de substâncias psicoativas.

A realidade concreta que nos interessa esclarecer, que descreve esse paradigma de modo muito simples, configura-se em alguns dos aspectos que envolvem o trabalho de promoção da saúde com um grupo de pessoas específico, no caso adolescentes ${ }^{3}$, que se encontram num certo patamar de consciência acerca de sua própria realidade existencial bem como de suas relações com seu entorno. A meta constituindo-se em propiciar-lhes alcançar um outro patamar de percepção de si mesmos e do lugar que eles podem vir a ocupar no mundo em termos de sua capacidade de lutar pela transformaçāo da existência como um todo - identificando e apropriando-se assim, dos meios necessários para alcançar uma vida saudável.

Podemos entender o significado mais imediato dessa transformação caracterizando-se, justamente, em sua adesão a um modo de pensar e viver que - pela inclusão de novos termos de referência e, portanto, de perspectivas, ao mesmo tempo, positivas (na medida em que se produza o alargamento de suas possibilidades de vida/viver, num horizonte de progresso tangivel e alcançável) e críticas (a partir do exercicio de seu discernimento e sinceridade), venha a excluir 0 uso de substâncias que interfiram, via psique, em sua percepção a respeito de si mesmos e do mundo causando seu distanciamento artificial justamente da realidade que thes cabe transformar - sua realidade. 
Os sinais do êxito desse empenho, quando temos em mente adolescentes em situação de vulnerabilidade social, implicariam, por um lado, o acesso de cada indivíduo que se encontra no interior dessa população à adequada preparação profissional e intelectual, ao usufruto de bens e serviços (ai incluidos, desde alimentos em quantidade e qualidade suficientes, até os cuidados com a saúde, acesso ao trabalho, moradia, segurança...). Por outro lado, em sua mais refinada tradução, espera-se que essas pessoas possam vir a interferir "conscientemente" no conjunto de decisões políticas que as afetam, movimento esse que comumente se encontra intimamente ligado ao chamado exercício da cidadania, e às noçōes de justiça social e eqüidade. Todos compreendidos não meramente enquanto conceitos abstratos; mas como realidades a serem concretizadas. Cada um deles funcionando, ao mesmo tempo, como meio e fim a ser alcançado; tal é o conceito expresso, desde 1986, nas cartas de Promoção da Saúde, em particular na "Carta de Ottawa".

Mas a "transformação da existência como um todo", na perspectiva do paradigma existencial que postulamos, implica a inclusão da interioridade individual enquanto referẽncia fundamental para avaliação do "êxito" acima descrito. Isto remete à necessidade de uma melhor compreensāo do sentido da conscientização antes mencionada e, por conseguinte, da relação entre conduta e intenção. De fato, haveremos de mostrar que propiciar a fruiçäo da adolescência no que ela tem de mais belo, e difícil, em si mesma e, ao mesmo tempo, intermediar a passagem desses adolescentes em direção a sua vida adulta - seu destino inelutável - saudável pede a compreensão do processo saúde-doença tendo como ponto fundante a recuperação da saúde/doença pelo sujeito através,

\footnotetext{
${ }^{3}$ Vide exemplo descrito em Materiais e Métodos e Anexos/PAP, dos programas de promoção de saúde desenvolvidos no "Reino da Garotada" em Poá e no Colégio Lycée Pasteur.

"In "Promoção da Saúde", p. 19 e seguintes, editado pelo Min. Da Saúde, Brasilia/DF, 2001.
} 
sobretudo, de "uma relação intra-individual", nos dizeres de Lefevre". Sendo esta dimensão que, em nosso entender, na medida em que recupera 0 papel de vetor-força da vida, que é sempre vida em sociedade de um conjunto de individuos singulares, concede sentido e valor às dimensões política, sócio-econōmica, cultural e, claro, terapêutica dessa reapropriação. De modo que o esforço para a efetivação destas, que certamente proporciona fundamental alivio para as mazelas vividas por um jovem em situação de vulnerabilidade social, deveria harmonizar-se com a busca por um sentido interior da saúde que funcione como eixo para a estruturação de sua liberdade para ser humano. Com a relação entre fins e meios sendo rearticulada, podemos abandonar o que podemos chamar de fetichismo da saúde tal como historicamente ele teima em reconstituir-se alimentado pelo conjunto de ideais em pauta: alvo a ser conquistado como fim em si mesmo. De fato, mesmo havendo incorporado sofisticados conceitos como emponderamento e sustentabilidade, entendemos que 0 ponto máximo almejado beira pouco mais que a subsistência existencial. Urge reencontrar assim, seu papel de meio para o florescimento da vida.

A situação acerca do lugar de cada indivíduo no todo social e o exercicio do poder político que the cabe, tem grande relevância para o desenvolvimento de toda esta tese, por essa razão é adequado considerá-la desde este ponto já em detalhe. Bovero, tratando das questōes relativas ao exercício da democracia grega, ilustra bastante bem esse ponto ao lembrar que a praça ou assembléia, na verdade, são compostas de muitos individuos que, à medida que se tornem aptos a exercer um efetivo poder de decidir contam cada qual como um ente singular. De modo que:

(....) o povo como corpo orgânico não é um verdadeiro sujeito de decisão: quem decide (...) são os individuos considerados singularmente. A decisão coletiva "do povo" só pode ser a somatória

\footnotetext{
${ }^{5}$ Lefevre, Femando, in “O Processo de Constituição do Sujeito, da sua Saúde e de sua Doença”, apresentado à FSP da USP para o concurso de Livre Docéncia, SP, 1995, pp. $169-70$.
} 
das decisões individuais, ou seja, dos pareceres de aprovação e desaprovação singularmente expressos por cada um. "

De modo que "o poder (krátos) de tomar decisões coletivas, ou seja, decisões vinculativas para todos, exercido pelo povo (dêmos), quer dizer pela assembléia de todos os cidadãos enquanto membros do dêmos, (só acontece) mediante (a soma de) livres escolhas individuais". ${ }^{B}$ Além disso, é bom lembrar que a separação que fazemos entre o campo interior do individuo e o campo geral do coletivo é uma abstração que nāo condiz com a unidade dessas duas realidades vivida na polis grega. Assim, a polis é uma "palavra de sentido concreto que exprime o conjunto pletórico de vida da existência humana coletiva, assim como a estrutura orgânica da existência individual situada dentro daquela". " E o que nos interessa é saber - que exatamente cada um dos termos dessa asserção deve significar para que funcionem como termos de referencia que nos encaminhem a uma prática sanitarista junto a adolescentes em situação de vulnerabilidade social que se articule em torno de um eixo, as "coisas humanas" como diz Platão, que lhe dê um suporte inquebrantável de um ponto de vista ético e moral, pois, como veremos, esse é um dos pontos em que parece faltar algo.

O conceito que, nesta tese, dá suporte a esse ideário é "autonomia", que será discutido no decorrer de toda a reflexão, mas que pode ser entendido, neste momento, como absolutamente dependente, como diz Shah:

(....) do grau de consciência que temos de nossos pensamentos e reaçães, da consciência de nossas tendências, nossos pontos fortes e nossas fragilidades, da consciência ou inconsciência acerca da massa de condicionamentos que carregamos, em relação aos quais nenhum de nós teve, na aurora de nossa existência, qualquer poder em escolher aceitá-los ou rejeitá-los - dos quais, inclusive, neste exato momento podemos ser nada mais que uma presa ingênua. ${ }^{8}$

\footnotetext{
- In Bovero, Michelangelo, Contra o Governo dos Piores - Uma Gramática da Democracia, Ed. Campus, 2002, p. 16-17.

7. "Paidéia - A Formação do Homem Grego", Ed. Martins Fontes; SP, 2001, p, 560

${ }^{8}$ In Une apprentissage du soufisme, Guy Trédaniel Editeur, Paris, 2001, p. 34
} 
Nesse sentido, cabe em primeiro lugar caracterizar novas formas de compreensão e utilização de algumas idéias-guia que tem norteado o trabalho na área de Promoção de Saúde. Estas se apóiam em grande medida no conceito de cidadania e seu instrumento de concretização por excelência, na área de saúde, a educação para a saúdeleducação voltada para o desenvolvimento humano - com seus co-determinantes tal como a "auto-estima", ou seus desdobramentos desejáveis, o "emponderamento", e aqueles no imediato mais facilmente mensuráveis, como os "fatores de resiliência", por exempio. Tal como tem sido tratados no campo da saúde pública essas noções trazem embutidos alguns ideais de realização humana em tudo compatíveis com a causa sanitarista historicamente constituída. Estes não parecem refletir, entretanto, a complexidade presente em suas origens na antiguidade greco-romana, tal como os vemos tratados na filosofia platônica e em alguns de seus comentadores que nos servirão como referência constante. De fato, a consulta a essas fontes mostra a dependência inequivoca do conceito de cidadania em relação à idéia de uma formação integral do Homem que se refere a sua conduta e comportamento exteriores, tanto quanto a sua atitude interior - nem um nem outro nascendo do acaso, sendo antes "o produto de uma disciplina consciente". Como tentaremos demonstrar até o final deste trabalho, essa visão do homem que - percebe orientado-se para "um fim ou uma altura conscientemente desejados" e reconectando-se com uma certa unidade interna, implicaria forma e tensão próprias, permitindo-lhe viver, sem obsessão, mas "continuamente em guarda com os olhos no alvo". 9

Combate esse encaminhamento o posicionamento centrifugo encontrado implícita ou explicitamente presente na condução de um programa de promoção da saúde, que se volta para a mobilização das consciências sim; acontece que, muitas vezes, seu foco de avaliação e validação visa sobretudo certos sinais relativos às condutas e às condições 
de existência exteriores - o que, é verdade, nos casos extremos que diariamente vivemos junto aos indivíduos económica, cultural e existencialmente periféricos de nossa sociedade, daria margem a uma avaliação já bastante animadora. Mas,

(....) as ações extemas são guias, (lembra Rumi)

Que indicam o caminho do que está oculto dentro.

Ás vezes, o guia é verdadeiro, às vezes falso,

Às vezes é ajuda, outras vezes é obstáculo".

(Rumi, Jalaluddin, Masnawi, Livro I, p. 58).

O problema é que tal restrição, quando ocorre, conferiria à noção de cidadania um sentido utilitário, banalizado, que terminaria por manter cada indivíduo ainda atrelado a seus condicionamentos e determinantes exteriores para estruturação de seu pensamento e ação, mantendo-o potencialmente passivel, portanto, de cooptação por este ou aquele grupo/partido/movimento/idéia.

Poderiamos pensar que essa maneira "restrita" de olhar o mundo estaria mais ligada à confirmação de algumas de nossas pré-concepções acerca de uma imagem da vida em comunidade - que mostraria, às avessas, uma proximidade com a concepção de higiene/higienização em curso no final do século XIX: enquanto esforço de segregação da doença/epidemia, "o mal", em certos territórios e/ou grupos sociais. Em nosso caso, essa delimitação forçada transcorreria, acreditamos, antes de tudo numa das esferas mais superficiais da consciência tal como descrevemos adiante, onde o exame minucioso dos conceitos de alienação e heteronomia encontrará sua validação.

De todo modo, estranha noção de vida em comunidade e de solidariedade seria essa que se mostraria fundada numa certa indulgência esquecida de que uma conduta, que, vale dizer, encontra-se sempre

\footnotetext{
${ }^{9}$ A citação é de Jaeger, W. Op. cit., p 570.
} 
encadeada a uma escolha acerca do destino final aspirado pelo seu agente, não pode ser baseada em ilusões. Pois, se estamos a falar em promover algo - a saúde - que, dependendo da população com que se trabalha, ou bem inexiste ou encontra-se em grave déficit, então estamos em face de uma responsabilidade que ultrapassa em muito o sanitarista de plantão que, inocentemente é certo, amalgama saúde com ideologia (seja de que lado for). Isto porque, se a produção/encaminhamento/postulação/absorção de uma concepção errônea por um adolescente pode induzir o pensamento à confusão e ao erro, a atitude errada por sua vez, quer dizer uma atitude de infidelidade para consigo mesmo, desviante em relação ao Ser do indivíduo, tem o poder de degradá-lo, podendo mesmo, eventualmente, vir a destruir a estrutura de seu próprio ser - reflexão tanto mais responsabilizante porquanto extensiva tanto para os educandos da promoção da saúde quanto para seus educadores.

"Então, não se deve julgar ditoso o rei dos Persas?

Não sei, responde Sócrates, pois ignoro qual é sua Paidéia e a sua justiça.

Como? É nisso que se baseia toda a felicidade?"

(pergunta Pólo, no Górgias 470 E, que não consegue compreender como Sócrates pode não julgar apetecivel o poder do tirano - citado por W. Jaeger, op. cit. p, 659).

Tal posicionamento encontra suporte na idéia de que o fim último de cada ser humano não se perfaz meramente no ver algo, mas em ser algo como bem o coloca Shah, SIA.:

"E no decorrer do esforço para ser algo que o individuo descobre sua derradeira oportunidade para objetivar-se e chegar a adquirir uma consciência de si muito mais fundamental que encontrará a evidência de sua realidade, como veremos discutido adiante, muito menos no eu penso cartesiano, do que na exortação kantiana: 'eu posso'" 10.

\footnotetext{
${ }^{10}$ In Islamic Sufism, 1933, newly edited version by Tractus Books, US, 2000, p. 102
} 
Esta interpretação, como se sabe, constitui o fundamento de sua noção de autonomia, o que se encontra explicitado desde o Prefácio da sua "Fundamentação da Metafísica dos Costumes". Kant, ali, aponta como objeto de estudo de uma filosofia moral a descoberta das leis da vontade do homem, as leis da liberdade como ele chama, enquanto afetadas pela natureza, "quer dizer, leis segundo as quais tudo deve acontecer, (....) (mesmo que) ponderando também as condições sob as quais muitas vezes não acontece o que devia acontecer", em contraposição, tem ele em mente, às inexoráveis leis da natureza. Sem renunciar ao conceito da natureza nem ao da liberdade, o reino da necessidade e o reino da escolha, ao final da Terceira Sessão de seu ensaio (Do limite extremo de toda filosofia prática) concede ele que, sob um ponto de vista prático, e não somente especulativo, "o caminho de pé posto da libendade é o único por que é possivel fazer uso da razão nas nossas ações e omissões ${ }^{n 11}$ - o que constitui um refinado encaminhamento da responsabilidade individual bem como da imperiosidade ético-civilizatória também encontrado em Freud como veremos adiante.

Interessa, assim, encontrar e agregar um outro significado ao conceito de cidadania e à noção de educação para a saúde, o que faremos buscando pela origem de sua formulação na antiguidade grega. Encontramos ali que essas idéias permaneciam devedoras, como já foi citado, da concepção mais ampla de "formação" do Homem, com a qual se buscava alcançar uma forma integral/integra desse homem que se manifestasse, ao mesmo tempo:

1) Em sua conduta e comportamento exteriores - através dos quais o cidadão livre teria condiçōes de exercer o poder de agir sobre o estado de coisas existente. ${ }^{12}$ Aludo aqui ao

\footnotetext{
${ }_{11}^{11}$ Fotocópia da trad. portuguesa estabelecida por Paulo Quintela em agosto de 1948.

${ }^{12}$ Condição que, é preciso lembrar, a partir do século IV a.C parece ter constituido somente uma liberdade formal: "Sob o nome de democracia, era de fato o primeiro cidadá (o estratego) que governava", esclarece Tucidedes (II,65,9). De fato, a partir do século IV AC, nos diz Jean-Jacques Maffre, apesar do pagamento de uma ajuda de custo diária, 0 mysthós, e apesar dos apelos e exortaçōes lançados aos ociosos da ágora, eram poucos os cidadãos que freqüentavam as sessões da Eclésia. "Os doentes, os muitos idosos, os que moram muito longe, os que já ocuparam um cargo e pensam já ter cumprido seu dever
} 
momento da passagem da Arete (a percepção de cada virtude em particular visando fins também particulares) à Paidéia propriamente dita - quer dizer, à formação do homem em acordo com certos ideais de justiça, a qual virá a ser equiparada à Virtude enquanto tal por Aristóteles na sua Ética.

2) Em sua atitude interior, através da qual o Homem ascende à autonomia ao fazer suas, pelo uso de seu discernimento, fruto de cuidadosa formação, as leis "belas e boas da cidade"13 quer dizer, leis que, até um dado momento da História e da história pessoal, permanecem como a Lei de outrem, às quais se está obrigado a obedecer e nada mais... Afinal, é necessário ter em mente as profundas dificuldades que se interpõem entre um homem e sua formação em termos de Paidéia, pois como lembra Veyne, submetido à tirania da opinião pública, "o cidadão era como um aluno preguiçoso que só respeitava a disciplina sob a palmatória do mestre" 14 - condição intemporal, pois passado e presente aqui certamente interpenetram-se. Essa autonomia mostra-se necessária à integração $e$ harmonização das dimensões tempo-situação-pessoas que terminam por configurar-se numa conduta adequada, seja de um ponto de vista intimo e pessoal, seja na perspectiva abrangente da vida em comunidade - devendo, por essa razão mesmo, contrapor-se à heteronomia.

civico, pouco a pouco deixam de freqüentar a assembléia, onde aliás se encontram quase sempre os mesmos cidadãos, ouvindo os tribunos que exercem um poder político de fato fundado na eloqüéncia." In A Vida na Grécia Clássica, Jorge Zahar Editor, Rj, 1989, p. 116 e 117.

${ }_{13}$ Deve-se lembrar que a enorme influência da polis na vida dos individuos, como diz Jaeger, $W$., baseava-se na idealidade do pensamento que a regia, o que tinha como implicação a conversão do Estado "num ser especificamente espiritual que reunia em si os mais altos aspectos da existéncia humana e os repartia como dons próprios". Forjava-se assim, o que se compreendia como o verdadeiro espírito comunitário que tanto orgulho produzia nos cidadãos gregos em serem membros de sua polis - a ponto de a identificação total de um grego exigir não só o seu nome e o de seu pai, mas também o de sua cidade natal. 
Vale esclarecer que a justiça designada no item " 1 ", tal como convém ser visada, é um conceito prático e operativo, nada contendo de abstrato. Consiste num esforço de conformação interior da alma individual em torno de uma ordenação que, na verdade, corresponde à sua própria essência, seu próprio cosmos. Em acordo com essa ordem, cada uma das partes da alma, obedecendo a uma hierarquia que, pouco a pouco, no decorrer de toda uma vida, é experimentada como imanente, "faz o que the compete tomando o Homem capaz de dominar-se e de congraçar numa unidade a multiplicidade contraditónia das suas forças intemas"15;

Para além das prioridades pessoais impostas, vendidas, por um mercado neoliberalizado e mediático, nos aproximamos assim do ideal grego na sua melhor tradução, onde autonomia significava, é certo, a vontade que, consciente de si mesma, quer exercer um poder sobre a vida pública, mas que por sua vez encontrava-se intimamente ligada à idéia de autodomínio pois a ninguém seria lícito governar se não soubesse se governar. O que se aplicaria até mesmo para o homem de máximo poder, o tiranós, pois caberia ao verdadeiro dominador, segundo o ideal socrático/platônico da Paidéia, sobretudo dominar-se e não dominar aos outros - e aqui fica mais claro o sentido da admoestação lançada por Sócrates a Pólo na situação acima mencionada. Por dominio de si entenda-se a obediência da alma ao que se denominava logos. De fato, "a alma só se deve deixar levar pelo fio macio e dourado com que o logos a puxa e não pelos duros e férreos fios dos instintos" ${ }^{16}$.

Mas, como não deixaremos de frisar durante todo este trabalho, é a escolha baseada numa reflexão valorativa que distingue uns dos outros indicando-nos, à maneira de uma sugestão sutil sempre reiterada, a escolha do logos em detrimento dos chamados instintos - como insiste Platão no

\footnotetext{
14 Veyne, Paul, "O Império Romano", in História da Vida Privada I, São Paulo, Companhia das Letras, 1990, p. 165.

${ }_{15}$ Jaeger, $W$., op. Cit. p. 811.
} 
Górgias, ao negar o valor da retórica que ele define como mera rotina e simples capacidade, baseadas na experiência e dirigidas a obter o aplauso das massas e nelas despertar emoções associadas ao prazer, aspirando assim tão somente a agradar-lhe ${ }^{17}$. 0 logos, diversamente, ao visar a consecução do melhor no homem submete o agradável ao que é bom e salutar, de modo que o agradável tem que ser pura e simplesmente perseguido por causa do bem e não o inverso, que é o que sucede quando tem lugar a alimentação do que não é o melhor no homem ${ }^{18}$. Provoca-se assim a perversão desse melhor, o que termina por acarretar a substituição, por exemplo, da legislação pela sofística, da justiça pela retórica, da sinceridade pela voracidade.

Lembremo-nos, a esse título, da condição a que se expõe o rei Midas para que possamos compreender simbolicamente a situação exposta. Este, quando já arrependido pelo desejo realizado por Dionísio de que tudo que tocasse se transformasse em ouro, teve uma nova chance, sendo confrontado a uma nova escolha em que é chamado a arbitrar entre os harmônicos da lira de Apolo e a sedução da flauta de Pã. Preferindo (escolhendo) esta àquela, o desafortunado só faz confirmar seu afastamento estrutural da sublimidade em favor da perversidade voraz.

Atentemos que não se está aqui a propor um estado ideal qualquer para um ser humano, e ainda mais no caso de um adolescente em situação de vulnerabilidade social, inatingível ou intangivel. Somente, esse estado que, mais uma vez, tem um caráter imanente, não parece surgir por acaso, sendo antes o resultado de uma conduta que, como indicado antes, propõese ao auto-exame reflexivo e a uma disciplina, ambos desejados e determinada e pacientemente executados, de maneira a fazer vingar no ser uma certa ordem que, como dissemos antes, na verdade corresponde à sua

\footnotetext{
15 Jaeger, W., p. 1315-6 - “O fio do logos é tão somente o que governa o Estado sob o titulo de lei. Deus ou quem o conhece concede o logos a polis, que o instaura como lei".

${ }^{17}$ Górgias, 464 A-C5.
} 
essēncia, ao seu próprio cosmos - no sentido de uma ordem legal interior da alma. Caberá ai então, falar de uma "boa" alma, expressão que ultrapassa muito o estrito sentido moral concedido na atualidade. ${ }^{19}$ Quer ela significar o alcançar pelo homem da harmonia com o Ser, através do domínio sobre si próprio, de acordo com a lei que ele mesmo descobre no exame de sua alma.

A partícula "se" dos parágrafos anteriores - o indivíduo deve saber se governar - referimo-la ao binômio autonomia/heteronomia, o que reintroduz, justamente, a mesma situação aludida a pouco cabendo agora ser tratada através da Psicanálise e seu conceito de inconsciente. Resumidamente, neste ponto, trata-se de definir essa dimensão do ser humano que seria responsável pela aceitação de critérios de referência e condicionamentos sem qualquer exame mais rigoroso. De modo que, mesmo que esses condicionamentos estejam sendo registrados em seu inconsciente, a pessoa os estará absorvendo sem estar consciente do fato que eles foram registrados. O ser humano, já antes de seu nascimento, é um "pólo de atributos ${ }^{n}$ afirma Lacan ${ }^{20}$, e mesmo depois disso, ele tem que se espelhar em outrem como condição sine qua non para que se dê sua humanização, o que se constituirá, ao mesmo tempo, em sua condição para a liberdade bem como sua pior armadilha e prisão.

"Para onde vai a minha vida e quem a leva? /Por que faço eu sempre o que não queria?

Que destino contínuo se passa em mim na treva?/Que parte de mim, que eu desconheço, é que me guia?

\footnotetext{
${ }^{18}$ Preferi aqui o tratamento negativo dessa expressão em lugar do uso da palavra original "instintos", por demais promotora de confusão teórica e prática.

${ }^{19}$ Como explica Jaeger, W., "no grego a palavra 'bom' náo tem apenas o estrito sentido 'ético' que hoje se dá a ela, mas é o adjetivo correspondente ao substantivo Arete, e portanto designa toda a classe de virtude ou exceléncia. Do ponto de vista dos Gregos, o ético é apenas uma modalidade da tendéncia de todas as coisas à perfeiçăo", op. cit,p. 678

${ }^{20}$ In Ecrits, "Remarque sur le Rapport de Daniel Lagache", Ed du Seuil, Paris, 1966, p. 652 e seguintes.
} 
O meu destino tem um sentido e tem um jeito, /A minha vida segue uma rota e uma escala; /Mas o consciente de mim é o esboço imperfeito/Daquilo que faço e que sou; não me iguala.

Não me compreendo nem no que, compreendendo, faço.Não atinjo o fim ao que faço pensando num fim. /É diferente do que é o prazer ou a dor que abraço.Passo, mas comigo não passa um eu que há em mim.

Quem sou, senhor, na tua treva e no teu fumo?/Além da minha alma, que outra alma há na minha?/Porque me destes o sentimento de um rumo, iSe o rumo que busco não busco, se em mim nada caminha.

Senão com um uso não meu dos meus passos, senão/Com um destino escondido de mim nos meus atos?/Para que sou consciente se a consciência é uma ilusão?/Que sou eu entre quê e os fatos?

Fechai-me os olhos, toldai-me a vista da alma!/Ó ilusões! Se eu nada sei de mim e da vida, IAo menos goze esse nada, sem fé, mas com calma./Ao menos duma viver, como uma praia esquecida... (Femando Pessoa, Obra Poética)

Em certo sentido, trata-se então de descrever esse outro, "a quem me encontro mais ligado do que a mim mesmo e que no seio mais assentido de minha identidade para mim mesmo, é ele quem age em meu lugar".(Lacan) ${ }^{21}$ Essa excentricidade radical do sujeito em relação a si mesmo, que provém antes de tudo de sua imprescindivel inserção familiar/social alimentada afetivamente (positiva ou negativamente - levando em conta aqui a legião de excluídos material e/ou afetivamente), determinaria paradoxalmente um

${ }^{21}$ Lacan, J., "L'Instance de la Lettre dans l'inconscient", Écrits, Ed. Seuil, Paris, 1966, p. 524. 
estado de heteronomia para cada um de nós no qual o inconsciente exerceria uma função dominadora sobre o consciente. É essa relação de submissão que, guardadas as devidas proporçōes, caberia propiciar a transformaçāo em cada sujeito participante de um programa de promoção da saúde - no sentido que eu, enquanto consciência e vontade, deveria tomar o lugar, na condição de instância decisória, das forças obscuras que me dominam e que, no final das contas, agem à minha revelia escolhendo este ou aquele caminho, esta ou aquela conduta, valor, significado..., tornando-me fiel ou renegado apesar de mim mesmo.

Passa a ter cabimento assim, com todas as ressalvas efetuadas, a discussão acerca de qual ênfase deve ser dada ao exercício, de cada adolescente, de sua liberdade real, de ser, de escolher, uma vez que desimpedida dos condicionamentos que a cerceavam, e compreendida como ponto culminante e intenção subjacente a todo esforço de promoção da sua saúde.

Percebendo com atenção e sensibilidade a tendência em curso nos programas de promoção da saúde nos últimos anos, essa situação a propiciar irromper nos adolescentes, parece residir sobretudo em uma questão de método e não meramente em uma potencialidade que esteja esperando somente uma deixa para brotar.

(...) "Pode existir em todo homem o estofo de um homem superior. Mas raros são aqueles que aprenderam como abordar a situação. Ser um educando significa ser capaz de aprender, e não unicamente desejar aprender... A base da capacidade para aprender não é o desejo de aprender, mas a sinceridade. $E$ a base da sinceridade, é a honestidade e o sentido de limite..."

(1. Shah - The Dermis Probe, Octagon Press, London, 1970, p. 135) 
Como o mostra parte do esforço pedagógico desenvolvido com maior ou menor sucesso desde o final da primeira metade do século $X X$ e mesmo antes disso, a dificuldade parece concentrar-se realmente, primeiro, na manutenção de uma intenção positiva claramente estabelecida e determinadamente perseguida, segundo, na forma adequada de abordagem sempre em acordo com o tempo, a situação e as pessoas. 


\section{JUSTIFICATIVAS}

\section{A perspectiva da saúde pública}

\section{Quanto aos programas de promoção da saúde}

A perspectiva promotora de saúde tem fundamentado conceitualmente seu trabalho em princípios orientadores que pretendem desenvolver, nos sujeitos objeto de uma intervenção, certa capacidade, competência/habilidade e criatividade para a resolução de problemas, seus problemas/nossos problemas. Procura-se incrementar a solidariedade entre os membros do grupo/comunidade, como meio de alcançar funcionalidade e eficácia no encaminhamento de suas demandas, mas também como um fim em si mesma na medida em que valoriza, em todo processo educacional, o estabelecimento de relações mais éticas e humanitárias entre as pessoas ${ }^{22}$. Pressupõe-se por sua vez, de parte do agente/educador para a saúde, a instauração de uma relação de horizontalidade com os educandos, dado considerar-se imprescindivel o aproveitamento real de suas, educandos, experiências, saberes, atitudes, condutas, percepções e interpretações sobre a realidade que os cerca e que se impõe mudar. Esse esforço encontra seu complemento em uma pedagogia dita participativa que privilegia a problematização dos temas em debate através de técnicas dinâmicas em grupo, focando a aprendizagem em termos de mudança de comportamento e estilo de vida. Se quisermos, entretanto, colocar-nos um pouco além dos aspectos assistenciais e de cura e nos ocuparmos verdadeiramente de promoção da saúde, devemos lembrar da existência de certos pré-requisitos considerados básicos para o pleno desenvolvimento dos individuos, que condicionam e traçam limites, acredita-se, ao alcance desse grande projeto pedagógico. Assim, a paz, as condiçōes de habitação e de educação formal,

\footnotetext{
22 Esta é a perspectiva trabalhada por Adorno, Rubens C. F. ,ao abordar o tema da violência junto aos jovens em situação de vulnerabilidade social no texto: Capacitação Solidária - Um Olhar sobre os Jovens e sua Vulnerabilidade Social, AAPCS, 2001, SP, p. 47.
} 
disponibilidade de alimentos e renda suficiente para fazer face a essas necessidades, além do acesso aos recursos renováveis, constituem em graus variados, conforme a população e cultura local, limites mais ou menos flexiveis. ${ }^{23}$ De fato, é sabido que todos esses aspectos encontram-se alocados de forma desigual em cada comunidade concreta, postulando-se, no entanto, que eles não atinjam niveis que cheguem a comprometer, sistemicamente, uns aos outros, de tal modo que se torne impossivel algo mais que a sobrevida a propor.

Esses considerandos têm como foco as referências das Cartas de Promoção da Saúde desde Ottawa que, em 1988, encontraram espaço na constituição federal brasileira no interior da rubrica Saúde, dando lugar, pelo menos formalmente, a uma democracia baseada na chamada cidadania participativa. ${ }^{24}$

\section{Quanto ao uso e abuso de substâncias psicoativas}

A gravidade dos problemas gerados em todo o mundo pelo consumo de drogas licitas e ilicitas tem sido constatada por vários estudiosos já há alguns anos. Preocupa, sobretudo, sua crescente prevalência (Kessler e col. 1994) que tem acarretado problemas de saúde pública evidentes.

Mais especificamente, o envolvimento de pré-adolescentes e adolescentes com substâncias psicoativas têm obedecido em todo o mundo uma progressão quase geométrica (Kandel e Yamaguchi 1993; Galduróz e Col. 1997). Ao crescimento quantitativo, acresce o problema, bastante delicado, do consumo cada vez mais precoce dessas substâncias (IBGE/1998) - que no Brasil situa-se na faixa dos 11 anos (dependendo da

\footnotetext{
${ }^{23}$ Conforme Westphal, M.F. - O Modelo de Atenção na Perspectiva da Saúde Integral: a promoçāo de saúde e a estratégia de 'Municípios Saudáveis' - Sanare - Rev. Sobralense políticas públicas; 2(3): 4-9, out/dez 2000.

${ }^{24}$ Conforme Westphal, M.F.; Bogus, Cláudia M. - Formaçāo de Conselheiros de Saúde e a Prática Cidadã de Participação no Planejamento, Gestāo e Controle dos Serviços de Saúde, in Informativo CEPAM: Conselhos Municipais das Áreas Sociais; 1(3): 45-56, mar 2002.
} 
fonte e do público pesquisado), tendo sido constatado um aumento do uso experimental de $22 \%$ para $27 \%$ nos últimos 5 anos (CEBRID).

Como sabemos, os números que refletiriam com precisão a prevalência de consumo de drogas lícitas ou ilicitas nessa faixa etária esbarra num fator limitante que é a dificuldade de mensuração da ocorrência de um comportamento, a priori, ilegal. Além disso, temos a questão da população estudada que, em sua maioria, deriva:

a) dos estudantes regularmente matriculados em escolas públicas (mais freqüentemente) ou privadas, o que elimina o contato com aqueles que, justamente por se encontrarem numa situação de abuso ou mesmo dependência, não mais freqüentam a escola;

b) dos registros de internação para tratamento ou atendimento ambulatorial que também tem um caráter obviamente seletivo. Acredita-se assim, que as estimativas sejam, na verdade, conservadoras e subestimadas em relação aos números reais.

Seja como for, o cruzamento de dados disponiveis de fontes diferenciadas brasileiras e a consulta de documentação internacional permitem ao pesquisador a corroboração das afirmações feitas inicialmente, pelo menos em termos de tendências. ${ }^{25}$

No que se refere à urgência de açöes de amplo espectro junto ao público adolescente, alguns números derivados de estudos epidemiológicos brasileiros são suficientemente reveladores. Carlini (1990) já referia alta prevalência de substâncias psicoativas, principalmente lícitas, entre

\footnotetext{
${ }^{25}$ Estaremos nos referindo principalmente: 1) Brasil: CEBRID (pesquisas desenvolvidas por Carlini (1990), Ferri (1994), Galduroz J (1997)); Associação Parceria Contra as Drogas/IBOPE (levantamento efetuado em janeiro de 2000); 'Pesquisa Avaliação das Açōes de Prevenção às DST's/AIDS e Uso Indevido de Drogas nas Escolas' - Unesco, UNDCP, Unaids, CN-DSTIAIDS (jun/2001).; 2) França: 'Tabac, álcool, drogues ilicites. Opinions et consommations des lycéens', De Peretti, C. et Leselbaum,N., INRP, 'Unité école et santé', 1991; 'Les lycéens parisiens et les substances psychoactives', De Peretti, C. e Leselbaum, N., Convention d'Etude avec l'Observatoire Français des Drogues et des Toxicomanies,
} 
estudantes de $1^{\circ}$ e $2^{\circ}$ graus - na maioria das vezes com uso esporádico e de experimentação. Em 1993, ainda entre estudantes de $1^{\circ}$ e $2^{\circ}$ graus, num estudo de Scivoleto e col. (1997), 64\% dos entrevistados referia já ter consumido álcool em algum momento de suas vidas e destes, $18,6 \%$ faziam uso regular.

Entre estudantes universitários da cidade de SP, encontrou-se (Magalhães 1991) prevalência semelhante às anteriores, mas as drogas referidas como utilizadas alguma vez na vida eram, em ordem decrescente, álcool, tabaco, inalantes, maconha, medicamentos prescritos e cocaína.

Por outro lado, entre os adolescentes que buscam tratamento por uso abusivo de substancias no Brasil, as principais drogas consumidas, excluindo-se o tabaco, foram o álcool e maconha $(95,2 \%)$, seguidos de cocaina $(76,2 \%)$, inalantes e crack $(57,1 \%)$. (Scivoleto 1997$)$

Em pesquisa da UNESCO (2001) junto a estudantes de 10 a 24 anos de 14 capitais brasileiras ${ }^{26}$, detectou-se que mais da metade dos entrevistados consomem álcool (em média, a partir dos 13,4 anos, com a freqüência variando desde o uso diário até somente nos finais de semana e festas). Preocupa, como dissemos antes, essa precocidade de uso de álcool e tabaco, drogas legais que em princípio tem sua venda proibida por lei para essa faixa de idade.

\section{A situação existente dentro de uma perspectiva qualitativa}

Como se percebe pelos números apresentados, há uma situação grave de uso e abuso de álcool e drogas cada vez mais freqüente e próxima das crianças e adolescentes no Brasil - o que parece inscrever o país dentro

1999. Estas fontes, somadas a dados mais recentes, alimentam nossa reflexão neste trabalho. 
de uma tendência verificada em outros países ocidentais, nas Américas e na Europa, como efetivamente apontou o Relatório Mundial de Saúde 2002 da OMS. Fato é que o álcool e as drogas em geral aparecem em várias dimensões da vida do adolescente: junto ao grupo de amigos, nas festas, no ambiente profissional e nas escolas, algumas vezes até mesmo em casa, onde se observa a anuência ou mesmo incentivo dos pais em relação ao consumo de álcool, ou sua "autorização", via consumo próprio, para uso de maconha ou medicamentos, etc... Habituamo-nos a ver essa situação exaustivamente retratada nos jornais diários, nas revistas, na TV, nos debates acadêmicos, cada qual à sua maneira.

Uma das questões que se colocam é que, dada a magnitude do problema, sua superexposição pela mídia e a angústia que nos toma pelo contato sistemático com o sofrimento de crianças e adolescentes drogados, cria-se uma tendência a produzir-se o que podemos chamar de gradual diluição do problema do uso e abuso de drogas. Isso quer dizer que todos concordamos sobre a absoluta relevância do tema, mas ao mesmo tempo sentimos um certo desconforto e uma sensação de estarmos desprovidos de instrumentos adequados para poder interferir de modo positivo sobre a situação. E em geral não interferimos, até que nos sintamos direta ou indiretamente atingidos.

Isso muitas vezes provoca, seja uma tendência à banalização do problema, seja sua dicotomização estéril entre adversários radicais de um lado e quase apóstolos de outro - principalmente no que respeita as chamadas "drogas leves" , como a maconha, como pôde ser observado durante todo o episódio de autorização de uso de seu princípio ativo em medicamentos pelo FDA nos EUA, em 2000, e depois no Canadá.

Tais contradiçōes não podem nos impedir a percepção das coisas que podem ser feitas, desde já, com as crianças e adolescentes que se

\footnotetext{
${ }^{28}$ Id ibid
} 
encontram no que podemos chamar de "idade da experimentação". Este é o momento do desenvolvimento físico/hormonal e psíquico em que se colocam com mais força as questōes da formação da identidade pessoal, a manifestação dos caracteres de masculinidade e feminilidade e a explosão da sexualidade, etc. Toda essa situação, como é sabido, é fortemente balizada pela conduta e clima existentes na familia, tanto quanto pela inserção do adolescente no grupo de amigos. (vide pesquisa da Associação Parceria Contra as Drogas/lbope de fev 2000) - o que muitas vezes provoca uma certa contradição com os valores embutidos nas bases educacionais recebidas. ${ }^{27}$

Nessa perspectiva, frente à necessidade de escolha do caminho a tomar no "aqui e agora" de uma festa com amigos, por exemplo, as coisas podem ficar realmente confusas para um adolescente que quer sentir-se recebido pelo grupo.

Tragédias à parte, através dos programas de promoção da saúde, trata-se de propiciar aos jovens ajuda efetiva em termos do esclarecimento do que está em jogo nas atitudes de experimentação de drogas lícitas e ilicitas, suas possiveis, e previsiveis, repetições (sem omitir o prazer, que antecede os fenômenos da tolerância e dependēncia nos casos de abuso) e as consequeencias que as acompanham - do ponto de vista orgânico e psicológico/existencial.

Nosso trabalho em Poá, por exemplo, obedece a uma filosofia segundo a qual, um programa de prevenção ao uso de álcool e drogas em geral para adolescentes, deve ser abrangente o suficiente para contemplar, desde aqueles que não tiveram nenhum contato com substâncias psicoativas (prevenção primária); até os que já passaram por essa experiência, utilizando-as de maneira eventual e não mantendo uma interação mais prolongada com a substância (prevenção secundária).

${ }^{27}$ Esses valores e as possiveis contradiçōes geradas pelo contato com a vida, no seio da própria familia, são estudados de modo interessante por Laing, R.D. e Esterson, A, no livro 
Essa postura implica assumir que o consumo de álcool, tabaco, maconha, cocaina ou qualquer outra substância psicoativa por um adolescente, não predetermina seu consumo no futuro em bases abusivas ou mesmo de dependência, a menos que as condições de vida que acompanham esse consumo e os fatores a ele conectados sejam mantidos ou reforçados em seu aspecto negativo. Entre esses fatores, é necessário destacar a dimensão da liberdade de cada individuo no que respeita as escolhas que somente ele poderá fazer de sua própria vida. (situação tratada adiante)

Isto quer dizer que devemos considerar o jovem como um elemento decisivo, sim, mas que se encontra ligado a um sistema ordenado de relaçōes com outrem (o ambiente familiar, seus pares, as autoridades constituídas,...) e com a panacéia de "objetos", de grandes promessas e fácil consumo, que o cercam. Esses "objetos" tornar-se-ão tóxicos, dizem Peretti e Leselbaum ${ }^{28}$, no sentido próprio da palavra, indiferentemente para 0 adolescente ou para o adulto, a partir do momento em que o individuo desloca o poder que ele tem sobre si mesmo para o objeto eleito e passa a viver na dependência em relação a ele e seu presente imediato.

Em outras palavras, se um adolescente torna-se um toxicômano, essa atitude não estaria necessariamente ligada ao uso eventual de alguma substância psicoativa durante um certo periodo de sua vida. A compreensão da "opção" pela dependência química pede uma visão amplificada que abranja a passagem à vida adulta e o fracasso na construção pelo adolescente de sua autonomia - sua lei própria que, nesse período, deriva sobretudo das leis externas, mas que, num pacto condicional com o mundo adulto, ele as faz suas, e passa a respeitá-las de moto próprio. Este, aliás, o sentido mais profundo do tornar-se adulto, entendido como um processo de

\footnotetext{
'L'Equilibre Mental, la folie et la famille', Paris, Maspero, 1975

${ }^{28}$ Este tema è tratado com acuidade por Peretti, C. e Leselbaum, N., (1991) na Introdução da pesquisa 'Tabac, alcool, drogues illicites - Opinions et consommations des lycéens', INRP/Observatoire Français des Drogues et des Toxicomanies, Paris.
} 
desenvolvimento que nos acompanha até o final da vida - mais ou menos independente, portanto, tanto de seu aspecto temporal, quanto da situação de inserção sócio-econômica e política. Ao "escolher" o abuso e/ou dependência desta ou daquela substância ele permanece submetido à lei de outrem, instala-se na dependência, nos mecanismos de repetição, de necessidade, perdendo conexāo, tendencial e progressivamente, com a dimensão de sua liberdade - por conta de uma espiral descendente que mescla, complexa e contraditoriamente, sua escolha que desvanece e o elemento químico a ganhar espaço em seu organismo.

Tudo leva a crer que, nos dois casos, prevenção primária e secundária, um programa de promoção da saúde deve ser dirigido no sentido de informar os adolescentes e fortalecê-los frente à sedução do prazer imediato e as pressões culturais e de seus pares, através do tratamento, em grupo $^{29}$, de temas que se relacionam com esses tipos de comportamento e com a desejada ascensão (nem sempre consentida conscientemente) ao status de adulto. Isso inclui desde a irrupção da sexualidadelafetividade ao reconhecimento de uma identidade própria diferenciada, familiar e socialmente confirmada/recebida - mesmo quando nāo inteiramente identificada com a norma celebrada e prevalecente na comunidade que o acolhe; o que, afora as condutas francamente destrutivas e desviantes, na realidade parece ser a regra.

Essa linha de ação parece mostrar-se particularmente eficiente, pois, ao invés de caminhar repressivamente, numa postura de confrontação, enfatiza o valor da vida vinculando-a ao ideal de liberdadelautonomia tratado

\footnotetext{
29. A eficácia do trabalho na forma de grupos operativos e seus avatares encontra-se detalhada através dos trabalhos clássicos de Bleguer, José, in Temas de Psicologia: Entrevista e Grupos, SP, Martins Fontes, 1980; e também Pichon-Rivière, E., O Processo Grupal, SP, Martins Fontes, 1983
} 
a pouco, num clima não preconceituoso e de aberto questionamento enquanto fator de conscientização ${ }^{30}$.

\section{$O$ adolescente, as drogas e a familia}

Do ponto de vista da junção entre o adolescente, o uso/abuso de substâncias e sua familia, há indicações que os pais de filhos adolescentes enfrentam diversas dificuldades no plano da consolidação das relações afetivas em termos qualitativos e quantitativos. Nesse sentido, o estudo "Relação Afetiva Diminui Risco de Consumo de Drogas"31 apresentava dados interessantes que permitiam propor uma relação inversa entre o sentimento de amor, atenção, compreensão, conexão vivido pelo adolescente em relação aos pais e o exercício de atividades de alto risco/uso e abuso de substâncias psicoativas. (independentemente de habitarem lares com um ou dois pais) Mesmo na escola, descobriu-se que os relacionamentos positivos com os professores eram mais importantes na proteção dos adolescentes do que qualquer outro fator.

Por outro lado, outros estudos com adolescentes ${ }^{32}$ mostram uma correlação importante entre a falta de conhecimento dos pais dos sinais que caracterizam esse comportamento - que muitas vezes corre paralelo com sua desconsideração em relação ao desenvolvimento dos filhos - e a conseqüente dificuldade em lidar com as crianças, no sentido de facilitar seu desenvolvimento psicológico e social. Estamos falando aqui sobre a

\footnotetext{
30 Paradoxalmente talvez, essa é a filosofia embutida mesmo nas sugestōes do NIDA (National Institute on Drug Abuse) dos EUA enquanto principios fundamentais que devem estar presentes num programa de prevenção, in NIDA notes 14(6), 2000.

${ }^{31}$ Journal of American Medical Association, in Revista Mind, Ano III No 20. Estudo longitudinal nacional sobre a Saúde do Adolescente realizado nos EUA, entrevistou 90 mil estudantes da $7^{2}$ à $12^{4}$ séries, além de 18 mil pais.

32 "Os jovens e as drogas: opiniōes e atitudes", pesquisa IBOPE/Parceria contra as drogas, ano 2000.
} 
imposição de limites (tema mais freqüente), mas também acerca do diálogo franco e da construção conjunta - pais e filhos - de soluçōes para aquelas situações por ambos desconhecidas - uma vez que não há modelos préestabelecidos para o que seja uma atitude sadia em cada situação particular.

Outra característica presente nos relacionamentos entre pais e adolescentes expostos a situaçōes de risco tem sido apontada (pesquisa IBOPE/Parceria): expectativas irreais dos pais com respeito ao que deve ser o comportamento apropriado para seus filhos. Trata-se aqui da fronteira muitas vezes transgredida entre o projeto parental e a vida em construção do filho.

Merece também atenção 0 alto grau de tensão existente nas familias. Os padrōes de interação familiares; como percebemos na prática clínica de atendimento a famílias, têm se caracterizado, freqüentemente, como negativos; isto é, os pais, empenhados em ganhar a vida elou ganhar projeçăo, se envolvem com excessivas doses de critica, ameaças, declaraçōes negativas, chegando a puniçōes físicas que, muitas vezes, perdem qualquer conexāo - em intensidade ou significado - com a atitude do filho que mereceria corretivo mais (ou menos!) severo. Segue-se uma correspondente falta de interações positivas, como comentários positivos, elogios, o próprio contato físico e assim por diante.

\section{Fatores emergentes}

Outros fatores que vem ganhando relevância na escalada do consumo de substâncias em termos abusivos podem ser caracterizados como segue: 
1) a quantidade enorme de facilidades de experimentação criadas na atualidade, com a super oferta de substâncias, preços reduzidos, facilidade de compra, etc;

2) a pressão do grupo de amigos combinada com a curiosidade e a busca de satisfação pessoal. Esta, quando näo derivada de uma sensação de vazio existencial fruto da ausência de valores significativos, encontra respaldo na tão decantada, pois produzida e propagada mercadologicamente, imperiosidade de se alcançar o prazer, que funciona, inclusive, como medida de sucesso na vida;

3) a pulverização da responsabilidade de educação das crianças entre pais e os diversos "equipamentos sociais" e especialistas de toda sorte, com a conseqũente diminuição do suporte que pode ser oferecido pelos pais eles mesmos, o que acarreta menores chances de interaçōes positivas, sejam elas corretivas ou de carinholapoio - as quais, no fundo, encontram-se em intima conexão.

Ademais, sendo o consumo de drogas, álcool e tabaco aí incluídos, amplamente divulgado pela mídia via publicidade/merchandising e produtos culturais diversos, por um efeito de regurgitação, realimentam-se os mercados de cultivo, produção e distribuição das substâncias, como sugere Kokoreff, Michel $(99)^{33}$.

Em vista dessa situaçăo, talvez possamos nos interrogar se, do ponto de vista do pacto social subjacente à nossa. cultura, haveria ainda algum limite social visivel e palpável para uma menina ou menino de $12 / 13$ anos, por exemplo, que não aquele representado por pais que assumem valores positivos e que tentam passá-los para os filhos, ou aquele diretamente repressivo, que age impulsionado pelo temor ou pelo rancor, imposto à utilização das substâncias psicoativas, desde as ilícitas àquelas amplamente

\footnotetext{
${ }^{33}$ 'Les contextes d'usages du cannabis dans les cités' in Adolescence et Toxicomanie, Gilles Férréol et alli, Paris, Armand Colin, 1999.
} 
comercializadas licitamente, como álcool, tabaco, tranqüilizantes, ou anorexígenos.

\section{A perspectiva econômico-comercial}

De maneira a ajudar um pouco mais a compreensão do fenômeno de expansão da drogadicção e dos problemas de cunho epidemiológico que essa expansão acresce, cabe aqui ainda a análise desse "sucesso comercial" no qual as drogas se tornaram, englobando-as numa perspectiva da Economia Política. Podemos dizer assim, que neste quarto final do século elas ganharam contornos típicos de produtos de consumo - moldando-se às necessidades de seus públicos-alvo em termos de: 1) preço (ex. crack), 2) canais de distribuição (o colega de escola) e 3) publicidade explícita e/ou merchandising, com a banalização promovida via produtos da mídia, negativa ou positivamente. Como tais, tendem a obedecer às regras de um mercado globalmente "neoliberalizado", sem contar com uma de suas vantagens mais proclamadas, o efeito da concorrência.

Algumas sérias conseqüências dessa situação - que sabidamente permeia o processo de propagação de qualquer bem de consumo, sendo que as drogas ilicitas, no limite, podem ser vistas como mais um "case" particular da história do Marketing ${ }^{34}$ - devem, certamente, ser abstraídas. Como veremos adiante, esses fatores implicam profundamente a escolha pessoal de seus consumidores potenciais de uma maneira, ao mesmo tempo, sedutora e perversa (no sentido psicopatológico do termo).

As conseqüências e desdobramentos do uso e abuso de substâncias psicoativas por adolescentes merecem certamente aprofundamento maior no sentido de podermos encontrar os fios que ligam esse universal abstrato

\footnotetext{
${ }^{34}$ A ser observado como a linguagem tipicamente mercadológica parece adequar-se bastante bem à descrição proposta.
} 
à particularidade de um ato muitas vezes tido como restrito à subjetividade individual - postura criticada por Olivenstein, C. (in "O Destino do Toxicômano", por exemplo), que propōe a toxicomania como dependente da confluência entre o que ele chama uma personalidade, um produto e um momento sócio-cultural.

\section{O papel da saúde pública}

Caracteriza-se assim, a importância da elaboração de programas de promoção da saúde dirigidos especificamente à população adolescente como forma de atenuar a ação cada vez mais avassaladora da droga, para usar a terminologia do senso comum, que neste caso realmente procede. Isso porque, se para alguns adolescentes o uso de substâncias que promovem alterações no psiquismo fará parte apenas de seu processo de desenvolvimento, cessando quando da chegada de seu amadurecimento; para outros, em número crescente e cada vez mais cedo, esse contato implica a interrupção do processo normal de adolescência, trazendo graves conseqüências que tenderão a permanecer como uma marca na vida do indivíduo e no conjunto do tecido social que deveria lhes dar suporte.

Esse raciocinio, segundo alguns autores como lçami Tiba, deve abarcar todo o espectro das chamadas drogas, legais e ilegais, incluindo aí aquelas consideradas "leves", principalmente a maconha, cujo consumo, visto por outros autores até como relevável visto o baixo potencial tóxico da erva, pode acarretar segundo Tiba e, num outro sentido, Aratangy LR. ${ }^{35}$, atitudes desviantes progressivas, considerando-se o ser do sujeito na constituição de sua unidade fundamental em sua comunidade de referência, como pedia a filosofia platônica ${ }^{36}$. Constitui exemplo significativo dessa

\footnotetext{
${ }^{35}$ Içami Tiba, 'Anjos Caidos', SP, Ed Gente; 1999; Lidia Rosemberg Aratangy, 'Doces Venenos', SP, Ed. Olho d'Água, 1991, p. 17 e seguintes.

${ }^{36}$ É importante notar que é da excelência do Homem, fruto da unidade das virtudes que o habitam em torno de uma atitude por ele tomada em direção ao seu melhor, é de sua
} 
espiral crescente em que se pode tornar um "desvio", bem como de sua banalização, uma publicidade datada de maio/2001 apresentada nos cinemas da capital. Nela um adolescente é mostrado roubando um aparelho de som de um automóvel, ficando implicita sua intenção de, com o produto do roubo, comprar drogas. Acontece que sua mãe aparece de repente the dando uma tremenda bronca: "Meu filho, então eu já não te disse para pegar um agasalho antes de sair de casa..."; completamente alheia à situação do roubo e à intenção do rapaz.

No entanto, mesmo a percepção da urgência de ações de amplitude nessa área não garante a eficácia do resultado alcançado por uma intervenção que baseie seu trabalho em um approach repressivo elou aterrorizante - sabidamente ineficaz na sensibilização dos sujeitos dispostos ao consumo - ou nas demandas expressas por pais em ambiente escolar que muitas vezes tendem a priorizar a ação policialesca por parte da direção da escola na esperança, quase sempre vä, de afastar seus filhos do "flagelo" através da identificação dos maus elementos que poderiam contaminá-los. ${ }^{37}$

Françoise Dolto ${ }^{38}$ discute o foco/linguagem a ser utilizada na condução de uma intervenção junto a adolescentes de modo interessante, propondo uma linguagem que não seja de aprovação e muito menos de repressão penal ou condenação moral. Mas sim uma linguagem baseada na opção lúcida com conhecimento de causa: "Nós ouvimos vocês. A sociedade dá o mau exemplo ou propõe outros derivativos. É um direito seu preferirem os prazeres passivos. Mas saibam que chegarão à idade adulta sem ter realizado suas experiências e o risco é cair no isolamento".

excelência "que depende o que os gregos chamam de eudaimonia, prosperidade feliz; $e$ quando a lingua grega designa o bem-estar com a expressão 'fazer bem', esta expressão encerra, para Platão, uma sabedoria mais profunda que a advertida por aqueles que a empregam: no sentido da felicidade e do bem-estar, 'fazer bem' assenta pura e exclusivamente no 'agir bem", Jaeger W., op cit, p. 679. (grifos nossos) ${ }^{37}$ Vide relato das experiéncias no Reino da Garotada e no Lycée Pasteur. (anexos) 33 'A Causa dos Adolescentes' (Ed. Nova Fronteira, 1990, p. 135-136). Vide também a esse propósito os trabalhos apresentados e discutidos no Foro 'Repensando Estratégias Preventivas desde el Mercosur y Paises Asociados', B.Aires, maio/2001 
A ênfase é colocada por ela nos resultados/conseqüências esperados, pensando em termos ao mesmo tempo qualitativos, dada sua experiência clínica em hospitais públicos, e de média estatística, afinal, temos que ter presente que a vivência do prazer na toxicomania tem um caráter fundamentalmente solitário. Continua ela:

"Muito poucos depois de drogados, mesmo com drogas leves, conseguem libertar-se por que perderam a energia necessária para enfrentar a competição exigida pela conquista de um lugar. Eles não têm as experiências que lhes permitiriam defender-se no momento em que encontrem obstáculos na vida. Não precisamos pregar moral, mas devemos dizer aos jovens: Vocês estão entre aqueles que querem desaparecer ou entre os que dizem: embora seja difícil, eu agüento o tranco?"

Essa situação, que opōe formas de posicionamento veiculadas durante uma intervenção de promoção da saúde e a apreensão que delas é realizada por um adolescente, tendo como pano de fundo as possibilidades de sucesso ou fracasso quanto ao seu futuro, em nossa linguagem suas possibilidades de liberdade ou de alienação, essa situação pode ser ilustrada em algumas de suas facetas no conto que segue:

\section{O Candelabro de Ferro}

Havia uma vez uma pobre viúva que estava à janela de sua casa quando viu aproximar-se a pé um humilde dervixe (um buscador da Verdade). Parecia cansado acima dos limites suportáveis e seu manto de remendos estava coberto de poeira. Era evidente que necessitava de ajuda. Correndo à rua, a mulher exclamou:

- Nobre denvixe, sei que sois um dos Eleitos, mas há ocasiões em que pessoas tão insignificantes como eu podem ser úteis aos Buscadores da Verdade. Venha e repouse em minha casa. Afinal, não se diz comumente: "Quem ajuda aos Amigos, será ajudado, e quem os prejudica, deparará com obstáculos, embora não se saiba como nem quando isso acontecerá?" 
- Obrigado, boa mulher - disse o dervixe.

Entrou na humilde casa da viúva onde, após uns poucos dias de descanso, recuperou suas forças.

Acontece que a viúva tinha um filho chamado Abdullah, com poucas chances de progredir na vida, porquanto gastara a maior parte de seus dias, até ali, cortando lenha para vender na feira do povoado. Não pudera, assim, ampliar suas experiências de vida de modo a habilitá-lo a ajudar a si mesmo ou à sua mãe.

O denvixe então the disse:

- Meu filho, sou um homem de conhecimentos, ainda que pareça desamparado. Venha comigo, seja meu companheiro de viagem e compartilharei com você grandes oportunidades, caso sua mãe esteja de acordo.

A viúva, muito contente, permitiu que seu filho viajasse em companhia do sábio, e assim os dois se puseram a caminho. Quando já tinham percorrido numerosos países e suportado juntos duras provas, o dervixe assim se manifestou:

- Abdullah, nós chegamos ao final de um caminho. Eu efetuarei agora certos rituais que, se receberem acolhida favorável, farão com que a terra se abra e revele algo que a raros homens é dado ver. Trata-se de um tesouro oculto aqui já há muitos anos. Está com medo?

Abdullah aceitou a prova e jurou permanecer fiel, acontecesse 0 que acontecesse.

Então o dervixe executou certos movimentos estranhos, e emitiu muitos sons, imitados por Abdullah. E a terra se abriu.

O denvixe disse:

- Agora, Abdullah, escute bem, com toda a atenção possível. Você tem que descer à cavema que se abriu a nossos pés. Tua tarefa é de se apoderar de um candelabro de ferro. Antes de chegar a ele, verá tesouros jamais revelados a homem algum. Ignore-os, pois somente 0 candelabro de ferro constitui a tua meta e teu único objetivo. Assim que o encontre, traga-o aqui.

Abdullah desceu à cavema dos tesouros e viu ali, realmente, jóias deslumbrantes, inúmeros pratos de ouro, tantas preciosidades impossiveis de serem descritas por simples palavras que permaneceu inteiramente aturdido. Esquecendo as palavras do dervixe, recolheu em seus braços as jóias mais reluzentes que póde ver. Foi ai que percebeu o candelabro. Pensando que podena levá-lo para o dervixe e ocultar em suas amplas vestes uma quantidade de ouro suficiente para si mesmo, voltou a subir os degraus de pedra que levavam à superficie. Mas, ao sair da cavema, viu que estava próximo da casa de sua mãe, e que o dervixe desaparecera. 
Assim que correu a mostrar o ouro e os adereços que trouxera à sua mãe, estes pareceram fundir-se e desapareceram. Só restou o candelabro de ferro. Abdullah examinou-o então. Tinha doze braços e o rapaz acendeu uma vela num deles. De repente pareceu surgir uma figura semelhante à de um dervixe. A apanição fez um movimento giratório, então colocou uma pequena moeda no solo e se esfumou novamente.

Então Abdullah acendeu as doze velas. Doze dervixes se materializaram de imediato, moveram-se ritmicamente durante uma hora $e$, antes de desaparecerem, colocaram doze moedas diante de Abdullah.

Quando se recuperaram de seu espanto, Abdullah e sua mãe perceberam que poderiam viver folgadamente com o que thes rendia o candelabro. Tinham descoberto que poderiam obter diariamente doze moedas de prata por meio da "dança dos dervixes". Mas logo Abdullah se pós a pensar nas riquezas incalculáveis que vira na caverna subterrânea, e resolveu verificar se não haveria uma nova oportunidade de obter para si uma verdadeira fortuna.

Procurou ativamente, mas não conseguiu encontrar o lugar onde ficava a entrada da caverna. Mas agora, no entanto, já estava obcecado pelo desejo de tomar-se rico. E se pós a viajar pelo mundo até chegar certo dia a um palácio que era o lar do pobre dervixe a quem sua mãe dera guarida um dia.

Á busca durara muitos meses, e Abdullah se alegrou quando o levaram à presença do dervixe, agora vestido como um rei e rodeado por um grande número de discípulos.

- Agora, mal-agradecido, eu the ensinarei o que o candelabro pode realmente fazer - disse o dervixe. Pegou um bastão e golpeou o candelabro. De imediato, cada um de seus braços se converteu num tesouro maior do que tudo que o rapaz vira na cavema. O dervixe fez então com que o ouro, a prata e as jóias fossem recolhidos para ser distribuídos entre pessoas que os merecessem. E ali estava o candelabro intacto como antes, pronto para ser usado de novo.

- Agora - disse o dervixe - como não se pode confiar em que faça as coisas corretamente, e como faltou à confiança que depositei em você, deve deixar a minha companhia. Mas, já que pelo menos devolveu o candelabro, pode levar um camelo e uma certa quantidade de ouro para você.

Abdullah passou a noite no palácio e de manhãzinha conseguiu esconder o candelabro no alforje do camelo. E mal chegou de volta à sua casa, acendeu as doze velas e golpeou o candelabro com um bastão.

Mas fato é que ainda não aprendera como operava a magia, dai que, em vez de segurar o bastão com a mão direita, usou a esquerda. Os doze denvixes apareceram imediatamente, recolheram o ouro e as jóias, encilharam o camelo que fora ofertado ao rapaz, retomaram o candelabro e desapareceram. 
E Abdullah viu-se em pior situação do que antes, porque dali em diante viveria com a recordação de sua incapacidade, de sua ingratidão, do roubo que praticara. Ele não podia esquecer que a riqueza estivera ao alcance de suas mãos.

Nunca mais teve outra oportunidade, e sua mente jamais se aquietou".

(Idries Shah, Contes Derviches, Le Coumier du Livre, Paris, 1979, p. 51/54)

Particularmente interessante neste conto é o jogo entre, de um lado as melhores possibilidades descortinadas para o futuro de um rapaz e por outro lado a maneira como ele sela seu destino ao tentar enganar o dervixe, enganar o que este tão somente espelha, enganar na verdade a si próprio.

Dando continuidade à discussão, podemos supor que os resultados dos programas de prevenção são, a priori, considerados positivos, pois há certa conviç̧ão de que a simples melhora do conhecimento pelos individuos de um grupo acerca de um tema de prevenção (por exemplo, AIDS/DST's), via algum tipo de informação, tem implicação direta, maior ou menor, na diminuição dos seus "comportamentos de risco". É o caso da mencionada pesquisa UNESCO, onde se aponta que um minimo de $50 \%$ dos adolescentes entrevistados havia mudado seu comportamento depois de participar de algum projeto de prevenção à AIDS na escola. Esses jovens tendem a usar mais o preservativo, ter menos parceiros e menos relações sexuais com parceiros eventuais, além de evitarem com maior incidência fazer sexo com profissionais. Entretanto, resta saber se o mesmo raciocínio pode ser transladado, tal qual, para a questão das drogas cujo mal não é inteiramente percebido pelos seus usuários uma vez que, como se sabe, boa parte dos toxicômanos de hoje começaram seu consumo absolutamente persuadidos de que permaneceriam como usuários ocasionais ou recreativos, que seriam mais fortes que a droga, que não cairiam na armadilha como os outros. Além disso, para grande parte dos adolescentes que consomem algum tipo de substância psicoativa o "risco" é condição para seu uso. Seja como for, um dos principais problemas é que em seu intimo, 
"a maior parte dos usuários estão certos de que 'mais tarde', 'um dia', quando eles saírem dessa situação, tudo voltará a ser possivel (....) imaginam que um dia se tornarão ou voltarão a tornar-se seres perfeitamente sãos, campeões esportivos ou grandes sedutores". ${ }^{39}$

Fica claro então que o maior problema na questão do consumo de drogas é a subordinação de um indivíduo aos efeitos produzidos por determinadas substâncias alienando sua liberdade, às vezes em função do preenchimento de certos "lapsos" interiores, digamos assim, e ao prazer passivo que termina por produzir o fenômeno de tolerância; em seguida a dependência químico-psicológica, quando a escolha dá lugar ao império da absoluta necessidade; alienando-se por fim à dor e sofrimento provocado pela ausência do insumo exterior ou por sua impossibilidade.

Procede assim a discussão acerca do conteúdo e forma de um programa de promoção da saúde junto a adolescentes que, tendo como objetivo propiciar-Ihes a adoção de condutas saudáveis, fundamente-se em seus aspectos existenciais profundos tal como identificados, principalmente, na sessão I Objeto de Estudo e VI Terapeuein, aspectos esses usualmente intocados em muitos programas em curso - pelo menos do que se depreende da literatura consultada na preparação desta tese a nivel internacional (docs. OMS/promoção da saúde, docs. Leselbaun e Peretti, 1991/1999) e nacional (pesquisas CEBRID 1990/94/97, IBOPE/Parceria contra as drogas 2000), . Neste momento da reflexão, apesar da expressão merecer tratamento detalhado em todo o decorrer deste trabalho, uma conduta saudável quer significar a ativação e valorização para e pelo adolescente da conexão consigo mesmo e do contato com o outro, em lugar de usar dos poderes da fantasia hiper atrofiada na criação de prazeres produzidos pela indução artificial de estados auto-referenciados (tomando o cuidado de caracterizar esse prefixo "auto", no caso do usuário, justamente

\footnotetext{
${ }^{30}$ in "Vous, vos enfants et la drogue, M. Valleur, Debourg e J.-C Matysiak, Ed. CalmannLévy, Paris, 1990, p. 59/60.
} 
entre aspas, como analisaremos adiante).

A respeito dessa função de suporte caracteristica da vida imaginária para o adolescente, Dolto ainda enfatiza as dificuldades provenientes da fruição da satisfação intensa através do imaginário, seja pela masturbação no caso da sexualidade que irrompe, seja através do consumo de drogas, como um sorvedouro da energia que, na seqüência, se tornará imprescindível para que o adolescente consiga forças para "buscar na realidade, junto aos outros seres humanos, o apoio, a camaradagem ou o amor que o sustenta e ajuda-o a sair dessas armadilhas".40

Também Bettelheim, ao trabalhar o papel dos contos tradicionais na formação da criança, avalia o caminho a percorrer até a adolescência e de como essa fase deve àquela em termos de bases estruturais - do imaginário à realidade. ${ }^{41}$

Nos dois casos, trata-se de avaliar em que medida tais considerações implicam a vida daqueles que ouviram, e viram, "outras histórias" que não somente as da carochinha (às vezes nem mesmo essas).

Tratar de conteúdo e de forma implica, também, falar da visão de mundo, da concepção do que seja a adolescência/o adolescente, por parte daqueles que se propōem a promover a sua saúde, todos esses conteúdos manifestando-se, velada ou explicitamente, na intenção. Se continuarmos nessa via, entretanto, especificando mais e mais os prolegômenos e elementos constituintes de um programa de promoção da saúde para adolescentes temos de tratar/definir outros aspectos que fazem parte desse "lugar". Lugar esse para o qual acreditamos - nós, agentes dispostos a propiciar a fruição desse período da vida em bases saudáveis além de

\footnotetext{
${ }^{40}$ Op. cit., p. 20-21.

4 Bruno Bettelheim, "Psychanalyse des Contes de Fee", Maspéro, Paris, 1972 particularmente no capítulo "Transcender l'enfance à l'aide de l'imagination", p. 174 e seguintes.
} 
intermediar sua passagem para uma vida adulta também saudável - devam eles ser encaminhados a ocupar na sociedade, em sua familia, em sua individualidade.

Haveria proveito desse modo, aceitas as justificativas enumeradas, de que 0 trabalho de Promoção da Saúde pudesse contar com mais essas ferramentas, que constituem nada além do que os desdobramentos do paradigma existencial proposto. Elas permitirão:

A) Colocar num primeiro plano a discussão acerca da "intenção", tanto do agente de saúde, quanto dos individuos/grupo, participantes/alvo de um programa de promoção da saúde. Uma vez que haveria uma relação direta entre a qualidade dos resultados alcançados e a imagem/conceito de saúde encarnado por todos os envolvidos no programa (explicita ou implicitamente, consciente e, mais importante ainda, pois fora de controle, inconscientemente). O questionamento sobre a intenção das pessoas envolvidas numa intervenção visa a estabelecer como alvo o ponto mais elevado a que pode aspirar um ser humano em seu desenvolvimento tomando como referência o ideal de formação do homem na antiguidade grega acima referido. Este congrega, como vimos, os aspectos exteriores da conduta e do discurso, tanto quanto aqueles aspectos interiores, na falta dos quais as atitudes, quaisquer que sejam elas, por mais interessantes, espetaculares e identificadas com o que se considera ser um ideal a atingir num certo momento histórico ou assemelhando-se apenas com "o que pareça mais natural fazer", ou "àquilo que todo mundo faz", as atitudes tendem, com o passar do tempo, a não encontrar sustentação, tendem à corrupção via sucesso exterior elou abandono interior - entenda-se aqui corrupção como o que leva à decomposição, ao aviltamento no sentido de perda de substância e significado original, em contraposição a um seu antônimo que é edificação, levar à virtude;

B) Levar em conta a complexidade dos processos psíquicos em curso em cada individuo, mas também num grupo quando de uma intervenção visando promover sua saúde; 
C) Focar e intentar desenvolver a qualidade das bases interiores, nos moldes posteriormente descritos em termos de alienação e liberdade, sobre as quais deverá assentar-se a conduta de um individuo em seu processo de interação, mais ou menos conflituoso, mas que se quer sadio (o que comumente é associado ao complemento "crítica" - interação crítica), com o status quo; seja essa conduta caracterizada como libertária, revolucionária, emancipatória, de resignação, identificação, transformação, etc. dependendo das escolhas que cada individuo faça, em acordo com sua história, o momento, a situação e as pessoas envolvidas, e levando em conta a "mensagem" recebida (que se espera propicie as melhores escolhas possiveis em termos da realização de sua saúde);

D) Não menos importante, essa postura que pretende levar em conta a interioridade individual profunda nas intervenções de promoção da saúde, carrega em seu bojo uma ocasião privilegiada de auto-avaliação/exame pelo(s) próprio(s) responsável(is) pela intervenção, na medida em que permite o re-conhecimento, em si mesmo, de processos em curso em seu próprio interior, conscientes $e$ inconscientes, estruturalmente muito similares àqueles que são encontrados em seu "público alvo" nas diversas fases de um programa de promoção da saúde, do planejamento à execução e avaliação.

Vale dizer que não se trata, é claro, de propor uma formação psicanalítica ou em filosofia a todos os envolvidos com a promoção da saúde. Trata-se sim, de ter claro como um ideal a atingir, a par da transformação mais imediata (e urgente) das condições de vida/saúde de um grupo de jovens em situação de risco, pelo alargamento/aprofundamento da consciência de suas prerrogativas de cidadãos, ter claro as questōes que se colocam para todo aquele que aspira a uma real autonomia. Situação extremamente conectada e dependente de um modo de consciência amplificada, que podemos entender como existindo potencialmente próximo à consciência normal. Ainda que sua realização seja complexa, suas bases seriam relativamente simples Poderiamos defini-la como a consciência de 
nossos pensamentos e reações, nossas tendências, nossos pontos fortes e nossas fragilidades, deslocando o teatro das automáticas re-açōes e dando lugar ao que podemos chamar de reação refletida. Apesar de soar ao popular texto de auto-ajuda dos anos 50: "Como fazer amigos e influenciar pessoas" de Dale Carnegie, trata-se tão somente de bom senso. ${ }^{42}$

$\mathrm{Na}$ realidade entendemos que essa condição, como acima descrito, lança bases para o que poderiamos chamar com Horkheimer ${ }^{43}$ de emancipaçāo do indivíduo, o que não significa, esclarece ele, emancipação em relação à sociedade, uma vez que essa emancipação individual tenderia a promover certa junção entre o universal e o particular que permitiria à sociedade, inclusive, livrar-se da atomização em que ela se encontra.

\footnotetext{
${ }^{42}$ Shah, Omar A., Un Apprentissage du Soufisme, Guy Trédaniel Éditeur, Paris, 2001, p. 34.

${ }^{43}$ In Eclipse de la Raison, Payot, Paris, p. 144.
} 


\section{MATERIAIS E MÉTODOS}

Apresentamos aqui em primeiro lugar, a metodologia de trabalho utilizada nas intervençōes realizadas junto a adolescentes e familias na instituição "Reino da Garotada" de Poá. Logo depois, discutimos nossas referências filosófico-metodológicas.

O trabalho com adolescentes abrange jovens de $12,13(80 \%$, aproximadamente) e 14 anos, todos alunos do $\mathrm{CJ}$, Centro de Juventude. Foram escolhidos em função de sua proximidade com a situação das drogas - via algum ente familiar, região onde mora, uso experimental já realizado, segundo uma avaliação dos monitores que os acompanham, em geral, desde os 8 anos (vide perfil individual nos Anexos). Visando a promoção de sua saúde e, mais particularmente, a prevençāo ao uso/abuso de substâncias psicoativas, optamos por chamar o programa de "Projeto de Vida", na tentativa de nos conectarmos com o que há de mais essencial e positivo em seu esforço/nosso esforço. Nomeadamente, é nossa Intenção aproximá-los de seu "Ser essencial", familiarizando-os com essa dimensão interior que mencionamos na sessão anterior e discutimos mais detalhadamente adiante, caracterizando os beneficios da alimentação $e$ manutenção de uma fidelidade a si mesmos, fundada na consciência da consciência como proposto nos capítulos seguintes; é nosso Objetivo incrementar/valorizar certas dimensões de suas vidas mais intimamente relacionadas com seu ser essencial, propiciando que escolhas sejam efetuadas quanto a determinadas zonas ou dimensões que podem, devem ou deveriam ser melhoradas, incentivando-os a trabalhar sobre elas. A tentativa aqui é trazer à tona certa disciplina de pensamento e ação realizada com base em uma escolha - fórmula a que recorremos durante todo este trabalho - sadia, o que não implica uma alternativa dramatizante entre positivo/negativo, mas a atribuição de uma qualidade às coisas que se apresentam que as "classifiquem" em coisas úteis, coisas menos úteis e 
coisas mais úteis, na perspectiva de um seu julgamento interior. ${ }^{44}$; é nossa Tática introduzir novos termos de referência que propiciem o melhor dimensionamentolequacionamento da relação entre suas oportunidades interiores e aquelas que se apresentam no mundo; nossa Ação envolve a interação cuidadosa e sutil com cada participante e o grupo através dos instrumentos abaixo descritos. Assim, afastá-los ou reduzir os danos devidos ao usolabuso de substâncias psicoativas, constituindo-se em necessidade imperiosa mostra-se, ao mesmo tempo, como um desdobramento valioso de um conjunto de procedimentos.

\section{Descrição do programa "Projeto de Vida"}

\section{Desenho}

Como modelo básico o programa tem sido estruturado em 8 oficinas, com duração de 1 1/2 horas cada, onde são tratados os seguintes temas:

- Reconhecimento das situações fisicas, psíquicas e culturais próprias à pré-adolescência e adolescência: amor e sexualidade, DST's, impulsos /desejos, gravidez precoce; influência do grupo de amigos, a busca de novidades, o lidar com frustraçōes; imagens acerca da construção do mundo adulto, etc;

- Informação precisa e atualizada sobre drogas : Drogas lícitas e llicitas e seu modo de funcionamento no organismo : padrões de consumo; hipocondriase na familia; seus efeitos no sistema nervoso central e no comportamento quotidiano; comparação entre os diferentes niveis de problemas provocados por cada tipo de droga em circunstâncias variadas: risco de overdose fatal $x$ quantidade da dose; risco de incapacidade social $x$ tempo de uso; intensidade do sindrome de abstinência $\times$ tempo de uso, etc;

\footnotetext{
44 Essas considerações são construidas com base nos raciocínios desenvolvidos por Shah, OA., op. cit, p. 248.
} 
- Papel da familia como núcleo de apoio fundamental, com a reativação e otimização dos recursos de comunicação e relacionamento existentes;

- Formação/informação na estruturação do comportamento humano educação, sociedade, cultura, midia e o peso dos condicionamentos nas decisões pessoais;

- Propiciar a formação de vínculos comunitários/grupais de comunicação e atuação.

\section{Referencial Metodológico}

Nesta sessão, examinamos algumas possibilidades e limites do paradigma metodológico de minha escolha, a Fenomenologia, para a compreensão do tema em questão.

É fato razoavelmente estabelecido que, quando queremos compreender uma determinada coisa/fenômeno, só podemos utilizar os termos de referência de que dispomos, nos quais estamos imersos - isso, mesmo quando acreditamos escolher pontos de vista distintos dos nossos, pois essa "escolha" decorre, não linearmente é certo, dos motivos que me levaram a ela, meus motivos (ver discussão nos caps. sobre Alienação e Liberdade). Esses termos de referência estabelecem, por assim dizer, nosso horizonte de expectativas cujo destino será, a cada novo momento, em parte ser desiludido e em parte ser confirmado. Esse movimento é extremamente dependente do grau de humildade do pesquisador - principalmente nas áreas em que grassa o discurso como fonte de legitimação e evidência de produtividade.

Encontramos essas formulações acerca do caráter do conhecimento possivel ao ser humano, no pensamento fenomenológico sem dúvida (vide, 
como um dos muitos exemplos, a introdução de Merleau-Ponty à sua "Fenomenologia da Percepção" e, em especial, o cap. "O Sentir"), mas também, e por outras razões, na epistemologia popperiana (veja-se a esse respeito o conceito de expectativas no cap. "O Balde e o Holofote" de seu "Conhecimento Objetivo"). ${ }^{45}$

$\mathrm{Na}$ melhor das hipóteses, pode-se manter pequena margem de manobra frente a esses termos de referência, o que, no caso de um individuo isolado, se configura na chamada autocrítica. Pode-se objetar bradando as benesses de uma manipulação consciente e metódica do pensamento, graças ao seguimento das leis da lógica formal estabelecidas desde Aristóteles. Sendo eu um pensador/pesquisador inserido no sistema acadêmico, a objeção poderia lembrar ainda o eixo central da obra de Popper, retomado por Hempel ${ }^{46}$, qual seja a crítica livre advinda dos próprios pares vinculados à comunidade científica, fundada na etapa da "verificação" de hipóteses previamente formuladas - uma vez que a razão de ser mesmo de toda nova descoberta/explicação que se quer cientifica seria o de ver-se ultrapassada por outra melhor, mais abrangente. De qualquer modo, as duas ordens de considerações serão mais profundamente discutidas no decorrer do texto.

Antes de continuarmos a discutir o método em si mesmo, é preciso caracterizar outros elementos presentes no objeto de estudo, já aludido anteriormente. Nesta seção proponho-me a descrever o foco do trabalho que se pretende desenvolver desde uma perspectiva teórica/conceitual esperando que emirjam algumas das conexões com o tema específico do método e os capítulos que, na seqüência, tratam da Alienação/Autonomia e da Liberdade enquanto possibilidades de ser.

\footnotetext{
45- Merleau-Ponty, M., A Fenomenologia da Percepção, Paris, Payot; Popper, K.R., O Conhecimento Objetivo, São Paulo, EDUSP, 1975.

${ }^{46}$ in: A Filosofia da Ciência, RJ, Zahar, 1974, cap 'A Investigação Científica: Invenção e Verificação'.
} 
A proposta é dar substância ao "benefício da dúvida" quanto à liberdade que temos face à História e/ou ao produto que nos tornaram, a história que forjamos para nós e, ainda, a interpretação que dela fazemos dada nossa situação de nascimento e sua derivação muitas vezes mais ou menos engessante, em consonância com as circunstâncias que vivemos que muitas vezes nos aparecem como circunstâncias que vivem por nós. Estas, porém, mantém, assim o postulamos, estreita relação com a maneira como as vivemos - aludimos aqui à nossa inserção sócio-cultural e econômica tanto quanto ao "que fazemos do que fizeram de nós", como postula a formulação sartriana. O pronome "nós" quer indicar a extensão desse raciocínio a todo ser humano. (o que será discutido através dos temas da liberdade/autonomia)

Esse procedimento impõe-se como necessário para a distinção razoável entre o que seriam os fatos ou fenômenos que se apresentam a nós enquanto homens (e, no caso, de ciência), à nossa consciência, e a percepção que deles efetivamente temos condição de realizar. Da mesma forma caberá na seqüência discutir o tamanho dessa fenda, e a hipótese é que ela existe também para cada indivíduo em particular em relação a si mesmo, seja qual for seu status na hierarquia social e sua faixa de idade prioritariamente até no caso de um adolescente que se encontra no início do caminho de sua vida. 


\section{O Conhecimento na perspectiva fenomenológica}

Uma vez melhor caracterizada mais uma das facetas de meu objeto de estudo e da forma de atingi-lo, podemos agora nos debruçar sobre a situação metodológica mais especificamente e tratar do paradigma fenomenológico por mim escolhido, através do qual observarei o desenrolar desses acontecimentos na teoria que formulo, tanto quanto acontece no curso de minhas intervençōes na clínica e nas instituições onde participo.

Entendendo-se o conhecimento como algo que queremos chegar a possuir e que hoje nos possui, caracteriza-se uma busca que, da singularidade dessa minha intervenção sobre a realidade enquanto, ao mesmo tempo, pesquisador e participante da situação de intervenção, me remete à universalidade da condição humana em sua busca pela transcendência de seu estado. Parafraseando Al-Ghazzali: "para começar, o que procuro é o conhecimento do que realmente são as coisas, de modo que, indubitavelmente, terei de tentar descobrir o que o conhecimento realmente és.47

Este é o caminho que tomo na tentativa de elaborar as questões (ou seria melhor falar em "pulsões"?) ${ }^{48}$ que me impelem.

\footnotetext{
47 citado por Lefort, Rafael - in Os Mestres de Gurdjieff, Ed. Dervish 1983 p. 62.

${ }^{28}$ A alusão aqui é, evidentemente, feita a Freud e à teoria psicanalítica que será melhor discutida nos capitulos adequados. Nessa perspectiva, haveria primeiramente que reconhecer o caráter e o conseqüente peso atual do conjunto de minhas experiências passadas (sempre reatualizadas). Seria preciso reconhecer qual a hierarquia, as prioridades, estabelecidas (por mim mesmo?, pelo Acaso?; Filogeneticamente?, como o propõe Freud através da noção de "protofantasmas"?) na minha estrutura desejante. Isto porque se, com Freud, estabelecemos uma diferença fundamental entre desejo e pulsão - o primeiro - sendo compreendido como a re-atualização de uma satisfação original, portanto rigida e irreversivelmente estabelecida no interior de um mesmo circuito; e a pulsão ao contrário, sendo algo plástico/polimorfo, mas cujo "destino" de certa forma estaria sempre inapelavelmente pré-determinado, pois sua satisfação implicaria invariavelmente o percorrer de um mesmo caminho (o circuito desejante)- num paralelo com J. Monod (1970),/E.Morin,(1979) sobre existência X patrimônio hereditário - caberia o questionamento do sentido (o que é aquilo que permanece o mesmo sendo outro?) que se desvela na
} 
Caberia aqui estabelecer uma similitude que nos vem do seio da metafísica oriental. Ela está contida na concepção da relação que se estabelece entre homem/natureza, sujeito/objeto:

"O homem vê na natureza - escreve S. Hossein $\mathrm{Nasr}^{49}$ aquilo que ele próprio é, e só penetra no significado secreto da mesma, com a condição de ser capaz de penetrar nos mais profundos recônditos de seu próprio ser e de deixar de residir meramente na periferia deste. Os homens que vivem apenas na superficie do ser podem estudar a natureza como algo a ser manipulado e dominado. Mas somente aquele que se voltou para a dimensão interna de seu ser pode ver a natureza como um símbolo, como uma realidade transparente, podendo chegar a conhecê-la e compreendê-la no seu verdadeiro sentido."

Este pesquisador, ao tecer comentários sobre o caráter profundo da interação existente entre o homem e a natureza, nos está mostrando a condição fundamental, no ocidente tratada também pela psicanálise, da ação do homem sobre si mesmo (seu destino) e seu meio dentro de uma perspectiva, diriamos, não alienada ${ }^{50}$.

ubiqüidade de minha (minha?) vida pulsional? Qual o "arranjo" preparado anteriormente nos recónditos mais obscuros de meu ser psicossomático e que se interpōe agora entre mim e minha aspiração à Autarkeia. Espero que a discussão que deverá seguir nos capítulos subseqüentes aclare esse questionamento, mas de qualquer forma, como veremos adiante, essas questões impõe-se ao pesquisador, tanto quanto aos sujeitos/objetos de pesquisa.

49 In "O homem e a Natureza", Zahar, 1977, p. 98.

${ }^{50} \mathrm{O}$ que, como veremos em detalhe mais adiante, segundo os principios da Psicanálise, supōe a "tomada" pelo ego de espaços sempre maiores das regiōes onde reina o ld. Uma atividade, é claro, que nunca se completa, no sentido que não existiria como possibilidade concreta a transparéncia total de uma dimensăo sobre a outra - idéia que veremos pormenorizada tanto na perspectiva fenomenológica quanto psicanalítica. 
Visto que o conhecimento só é para um sujeito, (ele corresponde, como o diz Aristóteles ${ }^{51}$ ao mais agudo dos seus anseios) existiria então uma certa identidade entre os dois movimentos: a procura do ser do conhecimento estaria, ou, melhor dizendo, deveria estar, inelutavelmente ligada/entremeada com a procura do ser do sujeito.

\section{Do ser do conhecimento ao conhecimento do Ser}

Antes de tudo, certos pontos de referência que fazem parte integrante da estrutura conceitual da fenomenologia devem ser clarificados.

Numa primeira abordagem podemos dizer que falar de conhecimento, como o sustentava Kant, implica falar da experiência como seu veículo privilegiado - sendo que os dois conceitos nos remetem classicamente, de um lado, ao sujeito (sede do conhecimento) e de outro lado, ao objeto conhecido, bem como ao caráter de sua relação. É necessário reconhecer ainda a existência das dimensōes subjetiva e objetiva, de uma relação entre elas e, mais ainda, conferir um status diferenciador (porém não disjuntor) às noções de existência, indivíduo e sujeito - noçōes que tendem a ser vistas como metafísicas segundo o modelo mecânico e determinista da Física newtoniana.

Por outro lado, na procura do conhecimento positivo não se deve incorrer no erro de identificar a experiência sensivel àquilo que é dado na experiência, pois esta não pode ser reduzida àquela. Aquilo que aparece à consciência, o fenômeno, é, na interpretação de Husserl, "o que se mostra a si e em si mesmo tal como é", isto é, um elemento irredutivel, originário, e

\footnotetext{
51 ".... Aprender é o maior dos prazeres, não só para o filósofo, mas também para o resto da humanidade, por pequena que seja sua capacidade para isso..." (in Poética, 1448 b. 14). E ainda na "Metafisica" $(1,1)$ : "... no vigor de sua constituiçăo ontológica, o homem deseja ardentemente conhecer".
} 
não tem por que ser necessariamente algo sensivel ${ }^{52}$. Cabe a discussão da noção de experiência ela mesma. Tratar-se-ia de uma experiência do real a ser construida? Ou, como o quer a fenomenologia proposta por MerleauPonty, de uma experiência que, se identificada à percepção, não pode ser assimilada "às sinteses que são da ordem do julgamento, dos atos ou da predicação"s.

"O que sentimos, não o que é sentido,

É o que temos. Claro, o invemo triste

Como à sorte o acolhamos.

Haja invemo na terra, não na mente.

E, amor a amor, ou livro a livro, amemos

Nossa caveira breve".

(Pessoa, F, Fiç̧ões do Interlúdio/Odes de Ricardo Reis, [390])

A tentativa de captar o sentido profundo do real, tal como ele é apreendido e capturado fugazmente, parece demandar um outro entendimento do conceito de experiência que determina a necessidade de sua descrição "pura", para além de sua intelecção, visando alcançar a "experiência no seu estado nascente, antes que ela seja objetivada" - o que implica "questionar à experiência ela mesmo seu próprio sentido" 44 .

O que se propõe é a existência de um momento pré-reflexivo onde se inscreve primariamente em toda sua riqueza o sentido dos fenômenos vividos na consciência. Isto porque se assume que existe sempre um algo que serve de base à reflexão, que the é anterior e sobre o que ela pode assentar-se - existe sempre um anté-racional (anterior a qualquer racionalização), um anté-predicativo (anterior a qualquer ato predicativo), que vai impregnar a consciência, como fruto de seu contato com um determinado fenômeno que lhe é revelado, primária e originariamente, na sua constituição essencial (o ser da coisa que se desvela à consciência

\footnotetext{
52 Husserl, Edmond, in "Meditações Cartesianas"

${ }^{53}$ Merleau-Ponty, M. Phenomenologie de La Perception, Paris, Gallimad, 1945, p. IV.
} 
numa doação original). Por sobre esta essência captada é que se vai constituir a imagem refletida da coisa, como que cooptada (do latim cooptatio - admitir por exceção, por privilégio) pelo sujeito da percepção.

Por um procedimento que pouco a pouco vai se legitimando no ato da revelação (enquanto tomada de conhecimento pelo sujeito), há que se caracterizar melhor o que se está a chamar de essência, cuja busca parece querer introduzir, em lugar da análise noética (de noêse, relativo ao ato de pensar), distanciada da experiência imediata, um caráter noemático (de noème, relativo àquilo que é pensado) à reflexão "que permaneça no objeto e dele explicite a unidade primordial, em lugar de engendrá-la155.

O que se encontra em jogo na "visão das essências" como é chamada por Husserl é a própria coisa que se desvela ao sujeito tal como ela é, segundo seu modo de apresentação original (o eidos) - que faz com que ela seja o que é, e não qualquer outra coisa. Um certo "principio de identidade", portanto, comandaria o conhecimento (entendido aqui, em seu sentido fenomenológico), pois, o que se tem como proposição é a tomada da consciência pelo sentido profundo da coisa por ela visada - a qual, por suposto, permanece a mesma, a despeito de todas as transformaçōes (aparentes) que ela pode sofrer, em função mesmo dos significados diferenciados, e até contraditórios, que eu lhe atribuo. É a irredutibilidade deste sentido que permanece idêntico e singular apesar de todas as variações possíveis, que vai permitir a tomada pela consciência da essência da coisa, a qual tem seu sentido de coisa; da cor vermelha que tem seu sentido de vermelho; da percepção que tem seu sentido de percepção etc... ${ }^{56}$ "A essência (o eidos do objeto) não será outra coisa senão a

\footnotetext{
${ }_{54}^{54}$ Merleau-Ponty, M. - op, cit., pp. 337 - 338.

55 Merleau-Ponty, M. - op. cit., IV. Esse é um caminho que nos leva de uma sintese de horizontes onde espaço e tempo transcendem-se a si mesmos, a uma síntese presuntiva "que deixa o objeto inacabado e aberto tal como ele é na experiéncia perceptiva", e desta ao objeto absoluto, a um "pensamento objetivo". (pp. 84-6)

${ }^{56}$ Ex. cit. por Shérer, R., op. cit. p. 296.
} 
explicação e o preenchimento desses sentidos, numa evidência própria que Hussert chama de eidética ou visão de essência" ${ }^{45}$.

Chega-se a ela através da supressão imaginária de todos os predicados "secundários" que constituem a coisa (enquanto conjunto de significados), o que acarreta a recuperação daqueles atributos predicativos (essenciais) que não podem absolutamente ser subtraidos, uma vez que tal operação implicaria a supressão da própria coisa enquanto tal. Há um processo de variação imaginária (arbitrária), que escuda a procura da essência, e que nos faz chegar a uma impossibilidade (de fato): impõe-se um limite à consciência que é ditado pela própria coisa, por sua essência de coisa que se mostra invariante e que "resiste", por assim dizer, às nossas fantasias.

A consciência aparece aqui com um caráter noético, pensando uma determinada unidade objetiva, atingindo-a numa certa medida ou num certo sentido. Cabe perguntar se a consciência, como o sustenta Levinas ${ }^{58}$ a propósito do pensamento de Husserl, constitui-se no receptáculo único do sentido do real, sendo "o próprio modo de existência do sentido"? Essa consciência singular não poderia em nenhuma hipótese assumir um caráter absoluto na formação do sentido que a habita: ela o conforma servindo-o. Em verdade, a realidade desvelaria uma relação de interdependência (que de início é significativamente assimétrica) entre o sujeito e os sentidos historicamente constituídos (o próprio sujeito encarnaria um pólo de atributos, antes mesmo de nascer, vai nos dizer $\operatorname{Lacan}^{59}$ ). A menos que se trate aqui de uma "consciência universal" estruturada a partir não de um único sujeito singular, mas sim, como o propōe Monod ${ }^{60}$, de toda a

\footnotetext{
${ }^{57}$ Id, ibid, p. 297.

${ }^{58}$ Levinas, E. En découvrant l'existence avec Husserl et Heidegger, J. Vrin, Paris, 1974, p. 49.

${ }^{50}$ Lacan, J. Ecrits, Paris, Seuil, 1966, p. 652 e seguintes. "Remarque sur le Rapport de Daniel Lagache".

${ }^{\infty}$ Monod, J. Le Hasard et la Nécessité - Essai sur la Philosophie Naturelle de la Biologie Modeme, Points, Paris, p. 194, 1970.
} 
ascendência da espécie - que carregaria assim, antes mesmo de se dispor como "consciência de", enquanto intenção, a essência universal historicamente herdada. ${ }^{61}$

A noção de essência, entretanto, nos leva a concluir sim a existência de uma oposição entre a "evidência direta (da coisa) ingenuamente vivida, e a evidência refletida que abre uma nova dimensão de racionalidade ${ }^{\prime \prime 62}$, por sobre a qual deve assentar-se o conhecimento. A diferença entre as duas faz-se sentir em toda a superfície de contato do meu ser no mundo (em meu horizonte de facticidade, nas palavras de $M$. Ponty), pois a cada momento coloca-se a questão da relação entre intenção/fins visados pela consciência, e aquilo que é verdadeiramente atingido: a evidência porta em si mesma, por seu próprio caráter constitutivo, a possibilidade do equívoco.

É por que não há prevenção adequada contra esses desvios e confusões, que se faz necessário tornar claro (num movimento de), equiparando-os às estruturas do real, os horizontes espirituais de onde emergem as evidências ingênuas. Isto como forma da se conseguir um desmembramento adequado entre os fins visados e os objetos alcançados o que abre a possibilidade, nada além disso, de se recuperar a totalidade do sentido da coisa visada, sua constituição real, mesmo levando em conta toda sua densidade e resistência.

A evidência da coisa, (ou intuição) assim atingida, propōe-se como o modo privilegiado na explicitação da essência própria a uma dada intenção. Ela é "a forma de consciência da aparição, da auto-aparição. A apresentação da coisa mesma, (....), a autodoação de uma coisa ou, do mesmo modo, de uma generalidade, ou também de um valor: é, pois, o modo de ser intuitivamente dado, originariamente" ${ }^{n 3}$.

\footnotetext{
61. Com a análise da idéia de 'horda primitiva' e de seus avatares, Freud, em 'Totem e Tabu', discorre longamente acerca dessa tese.

62 Levinas, E. - op.-cit., p. 10.

${ }^{6}$ Husserl, E. - Meditaçōes Cartesianas, cit. por Vera A., op. cit., p. 65.
} 
Encontrando o objeto (e não reencontrando-o) tal como ele é visado originalmente, a evidência existe numa relação de anterioridade vis-à-vis toda teoria construída ${ }^{64}$. A ela se opōem, portanto, tanto as intenções presuntivas como aqueles pós-significantes, definindo-se ao contrário por uma estrutura de consciência que se esgota exatamente na apresentação atual da coisa que é por ela visada (um conhecimento direto e imediato).

Isto quer significar, por outro lado, que a apresentação da coisa ela mesma através de uma intuição provedora originária - fonte de conhecimento - não pode nunca dar conta da totalidade da coisa, implicando ao contrário uma re-atualização sucessiva das evidências primeiras que se integram em estruturas cada vez mais complexas, tendendo a uma melhor compreensão do objeto visado.

O projeto até aqui descrito não determina uma refutação das evidências primeiras que seriam "ilusórias" em relação a uma verdade em si.

Não nos é necessário questionar se nossas evidências são verdadeiras, (....), pois se falamos de ilusão, isto quer dizer que nós a teremos reconhecido, e só poderíamos tê-lo feito em nome de uma dada percepção que no mesmo momento se atestava como verdadeira, de sorte que a dúvida, ou o medo do engano, afirmam ao mesmo tempo nosso poder de desvelar o erro e não poderiam nos desenraizar da verdade. Nos encontramos no interior da verdade e a evidência é a "experiência da verdade". 55

Assim, procurar a essência de um algo em geral através da evidência original que se revela à nossa consciência, implica na procura do que ele é para nós antes de qualquer tematização, implica, nas palavras de Plotino, em ver-se "todas as coisas, não no processo de 'vir-a-ser', mas no SER ${ }^{166}$.

\footnotetext{
${ }^{84}$ A teoria aparece aqui como o outro em mim, interiorizado através do discurso científico.

S5 Merleau-Ponty, M. op. cit., p. XI.

${ }^{\infty}$ citado por Huxley, A. -A Filosofia Perene, Ed. Civ. Brasileira, 1971 p. 12.
} 
Estamos adentrando aqui os descaminhos da questão da redução fenomenológica ou transcendental (époché) tratada por Husserl, procedimento gnosiológico que, se não tomado como fim em si mesmo, mas sim como tentativa que se percebe a priori como sempre frustrada do conhecimento absoluto, permite uma penetração adequada no conhecimento do fenômeno estudado, naquilo que o constitui como essência universal - o maior ensinamento da redução é a impossibilidade de uma redução completa, nos diz Merleau-Ponty ${ }^{67}$.

O processo de redução fenomenológica tenta ultrapassar, em radicalidade, a dúvida cartesiana, a ela opondo, como o explica Lyotard ${ }^{68}$, uma atitude pela qual o eu deixa de tomar posição em relação ao mundo como existente. Mas este não é um movimento que se volta para a consciência tida como fundamento do mundo, capaz, somente ela, da operação ativa de significação e onde o mundo, como explica M. Ponty ${ }^{69}$, nâo seria nada além da "significação mundo". Ao contrário, o conhecimento não se acaba com o retorno ao Eu, e através da análise da dialética e do paradoxo da relação estabelecida entre o eu e o outro (o ego e o alter-ego) que existe para-si, além de seu ser-para-mim, sendo que nós dois somos um para o outro. Conclui-se que tanto um como outro só podem ser "definidos" no interior de um horizonte de facticidade, numa dada situação histórica. $O$ Ser seria sempre ser-no-mundo, e a ele encontra-se entrelaçado inextricavelmente.

O sentido da operação redutora trata, no entanto, paradoxalmente, de subtrair o Eu tanto do dogmatismo do senso comum quanto do dogmatismo de racionalidade proposto pela Ciência ${ }^{70}$ os quais coabitam o espaço infinito

\footnotetext{
87. Op. cit., p. VIII - "La reflexion radicale est coscience de sa propre dépendence à l'égard d'une vie irreflechie qui est sa situation initiale, constante e finale." (Uma vida genérica que se situa para além de qualquer escolha. $p$. IX).

${ }^{68}$ Lyotard, J. François in La Phénomenologie, PUF, 1932, p. 20.

99 M-Ponty, M. - id. ibid., p. VI.

${ }^{70}$ Seja lá qual for o sentido da noção de racionalidade apropriado por cada um.
} 
de cada consciência singular. $\dot{E}$ um processo ideatório, portanto, realizado por um Eu, para quem, entretanto, o mundo natural e dos objetos não mais é tido como existente, mas como "fenômeno de existência".

Cabe aqui uma explicação, pois a noção de fenômeno, tal como intuída por Husserl, não se ajusta às significações a ela atribuída classicamente desde o século XVIII. O fenômeno, para ele, identifica-se em sua totalidade ao ser psíquico - ou consciência -, "não havendo, portanto qualquer distinção entre o ser e o aparecer ${ }^{\text {r11 }}$ - é aquilo que, uma vez dado à consciência, é por ela vivido. Há que diferenciar, no entanto, o fenômeno da "coisa fenomenal", a qual aparece à consciência sendo visado por ela como coisa, enquanto que o vivido é dado a si mesmo numa percepção imanente - o que quer dizer que a consciência não é experimentada como aparecendo a si mesma, sendo, ao contrário, absolutamente inerente a si própria.

Assim, quando se afirma que a consciência é consciência de algo, que ela visa sempre alguma coisa ${ }^{72}$, essa intenção que se dirige a um objeto vai atuar como depositária não da aparência do objeto, mas sim de seu próprio ser. Cabe-lhe, portanto, pronunciar-se sobre a maneira pela qual este ser se the é apresentado, ou seja, como ela o vive, elucidando o modo segundo o qual ela o visa ${ }^{73}$. Isto nas condições situacionais (de tempo, lugar e histórico existencial) em que se encontra o sujeito da percepção.

Voltando à questão da redução, dados os desenvolvimentos anteriores, não é o bastante afirmar a necessidade do Eu abstrair-se da dimensão mundana, pois é preciso ainda que haja uma consciência que seja

\footnotetext{
${ }^{71}$ Husserl, E. - La Philosophie comme Science Rigoureuse p. 83 - cit. por Schérer, René. in "Husserl, la philosophie et ses développements" (La Philosophie, $3^{\circ}$ tomo) Hachette, Paris, 1979 , p. 291.

72 "Se chegássemos a nos destacar do mundo e passar assim à consciència do mundo, verificariamos que a qualidade, no caso do sentir, não é nunca provada imediatamente, e que toda consciência é consciência de alguma coisa. Sendo que esta não é, inclusive, necessariamente, um objeto identificável." Merleau-Ponty, M, op. cit., p. 11.
} 
sujeito da redução. Assim, no limite, a redução nos conduz ao que é chamado de "Eu puro" - que é o Eu que trata de se abster de qualquer tese a respeito do Eu como existente ${ }^{74}$-, pois ele porta a operação redutora, inclusive, sobre a própria consciência. Isto não quer conferir um status ideal à consciência, em face da qual o mundo se mostraria totalmente transparente, ao contrário, tal processo recoloca, num outro nível, a questão do caráter das duas regiōes do ser em geral - a contingência da coisa e a necessidade do Eu puro - face ao problema da percepção (transcendente em relação ao mundo natural e imanente em relação ao eu).

Na redução fenomenológica, um e outro vão constituir-se em pólos opostos (a percepção - transcendente - da coisa, e a percepção - imanente - do Eu), pois enquanto nossa relação com a dimensão mundana é permeada pela dúvida - uma vez que não está nunca excluída a possibilidade de que o conjunto de nossas experiências revele-se como simples aparência, não passando de um sonho coerente ${ }^{75}$ - o sujeito da redução (o eu puro) é evidente a si mesmo de uma evidência apodíctica, o que significa que "o fluxo de experiências vividas (vécus) que o constitui, não pode ser colocado em questão nem em sua essência, nem em sua

\footnotetext{
${ }^{73}$ Shérer, R. op. cit., p. 291.

${ }^{74}$ Husserl, E. - Méditations Cartésiennes, cit. por Lyotard, J. F. - op. cit., p. 20.

${ }^{75}$ Morin, E., discute de maneira bastante apropriada essa questão em seu livro "Pour Sortir du Vinghtième Siècle", (Ed.Fernand Nathan, Paris, 1981, p. 19 e seguintes). Ao comentar a existència de uma componente alucinatória da percepçāo, e ainda mais de caráter lógico e racional, diz ele: "la distinction entre la vision réelle et l'illusion n'est pas donnée immédiatement. Effectivement, nous vivons nos reves, la plupart du temps, comme s'ils étaient notre réalité. Ce n'est qu'à de rares moments, entre veille et sommeil, que nous devinons que le rêve, qui continue ou meurt, n'est qu'un rêve. Ce n'est qu'après le revê que nous faisons la différence, que nous renvoyons le réve à l'irréel, et nous pouvons faire cette différence parce que nous retrouvons les mémes structures, les mémes données, les mêmes constances chaque matin. Toutefois, si nous étions chaque nuit victime d'un même réve, lequel se déroulerait dans um univers ayant les mémes constances et inconstances que le nótre (tal como proposto no filme Matrix, por exemplo - minha observação) nous serions fort troublés". Ele enfatiza ainda que é somente em uma civilização que comporta uma concepção lógico-empírica do real que se consegue opor claramente realidade e sonho. "Dans d'autres civilizations, nottamment archaïques, le rêve est reellement vécu par notre double, qui, pendant le sommeil, s'echape du corps et vit ses aventures".
} 
existência"m6. O que de per se não constitui uma garantia "epistemológica" a priori, colocando-se ao contrário, como uma posição a ser conquistada.

A necessidade de tal radicalidade - que força a subtração da consciência não somente do mundano, nas também de si própria enquanto consciência existente - vem daquilo que Merleau-Ponty chama de cumplicidade que é característica de nossa inserção no mundo a qual alcança uma intensidade tamanha que vai traduzir-se necessariamente numa postura inicial face ao objeto do conhecimento que tem como conseqüência as certezas (ou "não-certezas"!) tipificadas que passam despercebidas na atitude natural. Um caminho mil vezes percorrido portanto, cujo vinco é já muito profundo, só com muita dificuldade pode dar lugar a uma outra "escolha". Há que dele abstrair-se um instante para que haja ao menos a possibilidade de que se desvele à consciência uma outra cena, não necessariamente pela visualização concreta de um outro caminho, mas sim por um recuo efetuado através do vislumbre dos "fios intencionais" que ligavam o sujeito ao mundo.

Neste movimento, é a chamada reflexão radical que torna possivel a retomada de consciência (um reapoderar-se dela), pois no momento mesmo em que se está "formando e formulando as idéias de sujeito e objeto, ela deixa claro qual a fonte destas duas idéias, colocando-se não somente como reflexão operante, mas ainda consciente dela mesma"m?.

É preciso, entretanto, como foi dito anteriormente, guardar-se contra o sonho onipotente da redução completa, pois que se não há divinização possivel do humano - somos seres-no-mundo - e mesmo se nossas reflexões tomam lugar no fluxo temporal que elas procuram captar, (então) não existe pensamento que abranja todo nosso pensamento ${ }^{78}$.

\footnotetext{
${ }^{76}$ Lyotard, J. F. - op. cit., p. 23.

$\pi$ Merleau-Ponty, M. - op. cit., p. 253.
} 
Assim não havendo nunca uma posse absoluta do sujeito por ele mesmo, à redução transcendental, dado nosso caráter de seres-no-mundo, não cabe senão um recomeçar perpétuo em cujo horizonte perspectivo situa-se a essência daquilo que está sendo alvo de minha consciência, de minha intenção.

A análise de noção de intencionalidade nos remete forçosamente ao que Kant chamou de Refutação do Idealismo ${ }^{79}$, uma vez que somos "obrigados" a aceitar, a par da indubitabilidade da experiência interna, a facticidade da exterioridade, enquanto fundamento mesmo da interioridade se é que se pode cindir o incindivel, mesmo que seja para fins analíticos, uma vez que: "a consciência de minha existência própria é, ao mesmo tempo, uma consciência imediata da existência de outras coisas extemas ${ }^{\star 80}$ (o grifo é do autor).

Porém, como explica Merleau-Ponty ${ }^{81}$, há que se efetuar uma distinção entre as proposiçōes Kantianas e a teoria da intencionalidade formulada por Husserl, para quem, a vivência da unidade do mundo é antes experenciada como já feita/já existente, do que reconhecida pela consciência.

A intencionalidade exprime antes de tudo uma correlação intima, que se constitui na própria essência do conhecimento (enquanto compreensão pelo sujeito): estando sempre voltada para aquilo que não é ela mesma, a consciência estabelece uma relação com o objeto visado que não é aquela entre duas entidades exteriores e independentes, pois o que se tem é "de um lado o objeto, (....) como fenômeno remetendo à consciência na qual ele aparece, de outro lado, a consciência (que) é consciência desse

\footnotetext{
${ }^{78}$ Merleau-Ponty, M. - op. cit., p. IX.

19 Kant, E. in Crltica da Razão Pura, Ed. Tecnoprint, Rio, p. 278 - "nossa experiência interna, escreve ele, (....) é possivel somente sob a suposição da experiência externa".

${ }^{\infty}$ ld., ibid., p. 279.

${ }^{81}$ Merleau-Ponty, M. Phénoménologie de La Perception, Gallimard. Paris, 1945, p. XII e XIII.
} 
fenómeno ${ }^{\text {n22 }}$. Nestas circunstâncias, não se pode nem mesmo falar de anterioridade em face de uma ou outra dessas dimensões, pois consciência e mundo, no drama existencial, são dados em um único movimento: "exterior por essência à consciência, o mundo é, por essência, relativo a ela"83.

De forma aparentemente contraditória, o mundo, (como transcendência) se constituirá no meio irrecusável para que se dê a realização da consciência do sujeito (enquanto imanência). O objeto adquire assim, com seu caráter de transcendência, a possibilidade de sua inclusão no próprio seio da imanência do Eu. Sendo bastante interessante por sua vez observar que essa inclusão não é real, mas justamente intencional.

Isto quer dizer que o Ser da consciência revela-se como uma intenção dirigida a um algo que está idealmente presente no pensamento enquanto fenômeno - a vivência do objeto real visado pela consciência. Mas a intenção não demarca simplesmente uma relação que se estabeleceria entre o sujeito e o objeto. Ela indica, ao contrário, a própria maneira pela qual "freqüentamos" o objeto e o identificamos; o que se dá através do sentido, ou melhor, do ato de significação onde estão implicados, tanto o pensamento quanto o objeto real representado.

Observe-se que, aquilo que é visado não é a imagem de algo no mero pensamento, mas o próprio objeto - que, entretanto não me é dado "em pessoa", sendo simplesmente significado ${ }^{84}$. E esta atitude constitui-se na própria essência do modo de pensar que se configura no "simbolismo de

\footnotetext{
${ }^{82}$ Lyotard, J. F. - op. cit. - p. 310.

${ }^{8}$ Sartre, J.P. Critiques Littéraires (Situations, 1) - Une Idée Fondamentale de la Phénoménologie de Husserl: L'Intentionalité, Gallimard, Paris, 1947, p. 39.

${ }^{84}$ Levinas, E. Em Découvrant L'Existence avec Husserl et Heidegger., J. Vrin, Paris, 1974, p. 26.
} 
nossa atividade intelectual corrente sustentada pelos signos que anunciam as coisas, mas que se contentam em anunciá-los ${ }^{\text {n85. }}$.

A questão, portanto, envolvida na relação entre o pensamento e seu objeto é aquela do sentido do qual o objeto é revestido pela consciência năo cabendo perguntar-se se o objeto está ou não "refletido" tal qual na consciência.

Numa ponte com um dos temas fundamentais desta Tese, vale enfatizar que o ato de designar um sentido a alguma coisa, se tomado em sua radicalidade última, constituir-se-ia no meio privilegiado para o acesso do sujeito à autonomia - enquanto momento potencial de tomada de si mesmo, de seu próprio passado e futuro. O que supõe, porém, uma individualidade que se permite destacar-se de toda facticidade "imposta" pelo nascimento e pelo projeto derradeiro que se constitui na morte.

Se permanecermos em uma perspectiva que contemple o homem mediano no patamar em que usualmente se encontra, há que se relativizar a noção de significação de maneira a "ajustá-la" à realidade da "natureza humana", tornando-o mais próximo através da noção justamente de pro/jeto: enquanto engajamento que necessita sempre ser renovado, com vistas ao preenchimento de uma intenção; o que depende do sujeito (que tem de propor, é certo, um outro sentido) tanto quanto do mundo.

Voltando à questão da caracterização do objeto, entendida como descrição do sentido pelo qual ele é designado pela consciência e que o constitui de fato para mim, cabe ressaltar o aspecto temporal subjetivo e anté-predicativo que the è inerente. Isto porque a intenção que me leva até ele não pode ser limitada tão somente ao vivido (vécu) atual, que na verdade

\footnotetext{
${ }^{85}$ Op.cit., p. 26. Proposiçāo retomada de maneira magnifica por Eco, Umberto no seu Nome da Rosa, tal como transcrevemos adiante.
} 
encontra-se sempre cercado por uma aura (ainda que opaca) de vividos não atuais - o que confere à intencionalidade um duplo caráter.

Junto à intencionalidade do ato (aquela referida aos nossos julgamentos e tomadas de posição voluntárias) é preciso identificar uma intencionalidade operante, que é definida por Merleau-Ponty, como produtora de unidade natural (original, diriamos nós) e anté-predicativa do mundo e de nossa vida, que aparece mais claramente em nossos desejos, avaliações e paisagens, do que no conhecimento objetivo. ${ }^{86}$

O que se vai tornando claro, assim, é a impossibilidade total de se compreender o sentido como sendo expressão de uma razão que se esgotaria absoluta e unicamente no Eu (que seria tido então como fundamento absoluto, fonte de toda significação ou potência constituinte), onde não haveria portanto um peso específico para os signos naturais.

Mas, se na compreensão de uma coisa, por força do que se poderia chamar de intencionalidade "implícita", existe uma outra significação (mais profunda?) além daquela que se desvelaria na construção (constituição) atual pelo sujeito da sintese do objeto visado, então há que se estabelecer um outro pólo emissor de sentido que se constitui no mundo ele mesmo.

Nas palavras de Merleau-Ponty:

(....) quando eu compreendo uma coisa, por exemplo, um quadro, eu não opero sua sintese atualmente, eu compareço antes dela, com meus campos sensoriais, meu campo perceptivo, e finalmente com um modo típico de todo ser possível, uma montagem universal em relação ao mundo ${ }^{87}$.

\footnotetext{
${ }^{86}$ Merleau-Ponty, M. - op. cit., p. XIII.

${ }^{87}$ Merleau-Ponty, M. - op. cit., p. 490.
} 
Através da noção de intencionalidade operante, já em ação antes da emissão pelo sujeito de qualquer tese ou julgamento a respeito da coisa, conclui-se pela caracterização do ser do sujeito como uma essência ambigua que varia entre uma postura de atividade sintética/egocêntrica e uma postura extática ${ }^{88}$ em relação à qual toda a operação de significação apareceria como "derivada e secundária em relação a esta imposição da significação presente nos signos ${ }^{\prime 89}$.

Contrariamente a Husserl, portanto, mesmo se nos acordamos à visão da intencionalidade enquanto atividade constitutiva e essencial do sujeito, não se atribui aqui a ela o caráter de morada, onde o pensamento teria uma autonomia absoluta e onde a própria relação social - antes de se constituir num engajamento do sujeito anterior ao pensamento - teria tão somente o sentido de um pensamento ${ }^{90}$.

Arbitrando uma das situações primordiais com a qual se defronta o ser-no-mundo nos encontramos com a noção de ambigüidade. Através dela, como referido anteriormente, o sujeito é concebido, ao mesmo tempo, como promovedor da atividade sintática e (paradoxo!) como ek-stase; o que propicia $o$ alcance de instrumentos que possibilitam a compreensão aprofundada do perpétuo movimento de transcendência ativa do sujeito em relação ao mundo - que funda o homem enquanto liberdade, no seio mesmo da natureza/necessidade ${ }^{91}$.

Coloca-se uma questão neste momento quanto à operacionalização do conjunto das reflexões desenvolvidas neste capítulo em uma ação de

\footnotetext{
${ }^{88}$ Do grego ek-stase: ação de estar fora de si mesmo.

${ }^{20}$ Id., ibid., p. 490.

${ }^{90}$ Levinas, E. - op. cit., p. 48.

${ }^{91}$ Haveria uma discussāo interessante a fazer aqui pela contraposição desse ideário ao pensamento de Hegel, que ao final de sua Fenomenologia pleiteia um estado de "compreensão" / "reconciliação" do sujeito, que eliminaria a transcendência - in "La Phénoménologie de l'Esprit', trad de Jean Hyppolite, Paris, Aubier, 1941.

Num outro sentido, cabe também a leitura psicanalitica feita por Marcuse, H., em 'Eros e Civilização', SP, Círculo do Livro, 1982, p. 105 e seguintes.
} 
promoção de saúde junto a adolescentes. Nesse sentido, passaremos à análise do conceito de "compreensão", entendido como instrumento para a apreensão do sentido das condutas humanas, por exemplo, em uma situação de trabalho com um grupo. Seria este um momento no qual eu e o outro, enquanto homens (e não enquanto pesquisador e pesquisado/sujeito e objeto), nos unimos num processo "totalizador que reúne a meu próximo, a mim mesmo e ao ambiente na unidade sintética de uma objetivação em curso, 82 .

Isto quer dizer que nós (eu e o outro) nos relacionamos com vistas à concretização de um determinado fim que passa a existir como tal "para nós", a partir do momento em que meus fins particulares (trabalhar com os indivíduos " $x, y$ e $z$ " com 0 objetivo de compreender $e$ interferir positivamente ${ }^{93}$ em seu projeto vital) integram-se, esperançosamente, aos fins particulares por eles perseguidos - que, concordando em trabalhar comigo possibilitam a junção de nossas experiências. Esta junção/reunião atinge niveis diferenciados de integração, a qual se torna mais ou menos intensa no decorrer do processo de trabalho, em função da qualidade do contato estabelecido e da tematização que o sustenta - que podem fazer com que se mantenha o interesse inicial ou que ele seja destruído parcial ou totalmente.

Existe, é claro, uma unificação dos momentos que até então se encontravam dissociados (ligados tão somente pelo meio sócio-cultural comum) graças a uma certa previsão dos resultados visados. Mas esta pode ser confirmada ou anulada, dada as condições nas quais vão se concretizando os fins visados pelos dois, eu e o(s) outro(s). Inicialmente unificado através de uma mínima aresta que compõe a figura geométrica de

\footnotetext{
$\$ 2$ Sartre, J. P. - Critica de La Razón Dialéctica, Ed. Losada, B. Aires, 1963, p. 134.

${ }^{93} \mathrm{Com}$ a expressão 'interferir positivamente', quero dizer não somente imbuido de uma intenção de ajudar um grupo de adolescentes em seu caminho, mas também agir em acordo com certos termos de referência que se mostram adequados do ponto de vista de sua eficácia em relação aos fins visados na intervenção. Em meu caso, são aqueles já descritos até aqui $\theta$ também nos capitulos II e III seguintes.
} 
nossos projetos particulares, a evolução do processo pode promover nossa disjunção/separação.

De qualquer modo, minha compreensão do outro "não é jamais contemplativa: o que me une a ele é um momento de minha práxis, uma maneira de viver, na luta ou na convivência, a relação concreta e humana,94. Além disso, a compreensão - exprimindo uma atitude ativa (uma práxis) tanto da parte daquele que tenta compreender quanto da parte daquele que se faz compreender, o que torna a ambos permeáveis à interação e, portanto, ao trabalho transformador - a compreensão, dizia, está voltada não simplesmente para a pura e simples ação manifesta, mas sim para a referência (implícita) da práxis com a intenção. ${ }^{95}$

Ao estabelecer e manter os fios que ligam esses dois pólos, a compreensão pode ser designada, como a "apreensão totalizadora de cada práxis, enquanto intencionalmente produzida pelo seu autor (....) ${ }^{, 06}$.

Essa forma de descrição da compreensão tem como ponto de partida a convicção, trabalhada pela Fenomenologia, de que o conhecimento que nos é dado a obter seja no mundo físico, seja no mundo psíquico, retomando o que vimos anteriormente, não é limitado ao nível sensorial (externo ou interno) de percepção. Ao contrário, o conhecimento o transcende (ou pode transcendê-lo), pois, para além da simples percepção ingênua como indica Binswanger" "existe um outro modo de experiência muito mais original". Esse outro modo de conhecimento tem como resultado, algo como uma "possibilidade de incorporação", do sujeito do conhecimento no objeto considerado.

\footnotetext{
${ }^{94}$ Sartre, J. P. - op. cit., p. 135.

${ }_{95}$ Ainda que essa intençäo permaneça obscura e implícita para o agente, como diz Sartre, op. cit., p. 226.

${ }_{96}^{6}$ Sartre, J. P. - op. cit, p. 227.

97 Binswanger, L., "De La Phenomenologie”, p. 81, in Introduction à L'Analyse Existencielle, Minuit., Paris, 1971
} 
Assim, na visão, por exemplo, de uma árvore lutando contra o vento, o que Van Gogh "vê" é um homem lutando com o seu destino (um drama, portanto, e nāo uma árvore existente na natureza). Ele vê isso, mas sem percebe-lo pelos sentidos, pois não se trata de uma visão do olhar, mas de uma tomada de conhecimento direta ou intuitiva que desloca sua visão para um lugar de compreensão que se situa muito além da função e do domínio da percepção sensorial. Eis aqui o "lugar", ao qual, como vimos antes, Husserl dá o nome de intuição categorial. Um lugar que, neste momento, sugere-se ter menos proximidade com a razão do que com a visão, enquanto revelação da unidade das aparências do mundo.

"E assim é com os jardins, os riachos, as belezas paradisiacas, os palácios, as comidas, as bebidas, os presentes, os cavalos, as cidades, as casas, maravilhas de todos os tipos..., (ganham) forma aos olhos de quem vê.

O mesmo se passando com os estados de temor, segurança, calma que encontram sua unidade revelada pela visão e não pela razão.

“O filósofo sabe disso, mas através da razão; (porém) ela não é constante, e a felicidade que traz não é constante; enquanto se trabalha com a razão, experimenta-se a felicidade e o conforto. Quando não há mais argumentos a serem expostos, o conforto e a felicidade se dissipam. ${ }^{.99}$

Estas compõem as referências metodológicas que nos servem de guias para a elaboração de nosso pensamento acerca dos fenômenos que nos ocupam.

\footnotetext{
${ }^{98}$ Rumi, op.cit., p. 74

$\infty^{\circ}$ id ibid
} 


\section{A Forma de Exposição da Tese - \\ Do uso de determinadas formas literárias}

Mantendo coerência com o paradigma fenomenológico que adoto e permanecendo, ao mesmo tempo, na perspectiva psicanalitica que consubstancia uma parte deste trabalho, proponho a apresentaçāo de alguns dos temas que compöem esta tese empregando, como procedimento paralelo, imagens derivadas do uso de formas literárias tais como a poesia, os contos 'de ensinamento e a mitologia.

Com esse outro procedimento a intenção é tornar mais compreensíveis e operativos conceitos como "intuição original ou eidética" e "redução fenomenológica", como os entende Merleau-Ponty, principalmente, de maneira a alcançar o eidos da coisa visada por minha consciência ${ }^{100}$ - o que constitui exatamente um dos objetivos desta tese. Dito de outro modo, quero trabalhar, por exemplo, com o conceito de intuição à maneira como o apresentam Binswanger L. e Bacon R., ${ }^{101}$ citados adiante, visando-o como intuição da verdade.

Para compreendermos um pouco melhor esse tema cabe nos aproximarmos da filosofia platônica em sua análise do mito. Este, situado no interior da obra de arte, teria uma função aparentada ao resumo e à síntese, pois "quando a complicada elaboração teórica do pensamento lógico já há muito desapareceu da memória do leitor, continua a nela viver a imagem do mito que assim se converte no símbolo de todo o conteúdo filosófico da obra" ${ }^{102}$ Note-se que, nesse sentido, para além das interpretações possiveis, permanece resguardada a intenção original do autor na medida em que se estabelece uma relação de cooperação entre a forma

\footnotetext{
${ }^{100}$ Esses conceitos encontram descrição adequada no decurso deste trabalho.

101 In Binswanger L., "De La Phenomenologie", Introduction à L'Analyse Existencielle, Minuit, Paris, 1971; Bacon R., "On experimental science", 1268, Medieval Sourcebook, wuw. fordham.edw/halsall/source/bacon $2 . h t m I$
} 
literária/poética escolhida e o logos, ambos visando, necessariamente, um mesmo fim: a Paidéia - a formação do homem. Isto quer dizer que a forma artística/poética, para ser assim considerada, deve encarnar um ethos, um anseio espiritual, de tal modo que ela vai exercer uma ação propriamente "educadora" unicamente se ela tem o poder de fazer brotar, concomitantemente, as forças estéticas e éticas do homem - os dois interagindo e encontrando em sua parte mais íntima uma raiz comum. Nos encontramos distantes aqui da poesia trágica ou imitativa que, falando aos instintos e' às paixões, age num sentido oposto colocando o homem próximo à sua fase infantil.

A arte assim definida - chamada de psicagogia - tinha para os gregos um poder ilimitado de conversão espiritual (há que se ter cuidado aqui com o sentido extemporâneo e estereotipado que tendemos a atribuir a esse conceito nos dias de hoje); dito de outra maneira: "os valores mais elevados ganham, em geral, por meio da expressão artística, significado permanente e força emocional capaz de mover os homens". ${ }^{103}$ Lembremos que, ao lidar com um modo específico de alienação possivel nestes tempos - 0 envolvimento de jovens que vivem em situação de vulnerabilidade social com substâncias psicoativas - esta tese, como veremos, se pauta exatamente na compreensão de que a ação educativa em saúde tem como condição estar revestida de conteúdos que tenham validade universal e plenitude imediata e viva. Quer dizer, façam-se sentido e valor.

A arte em geral e a poesia em particular promovem a união dessas duas modalidades de ação sobre o espírito, sustenta Jaeger ao comentar Platão, superando assim ao mesmo tempo a vida real e a própria filosofia e a reflexão:

A vida possui a plenitude de sentido, mas as suas experiências

\footnotetext{
102 Tal como interpreta Jaeger W., in Paidéia, A Formação do Homem Grego, Martins Fontes, São Paulo, 2001, p. 687.

${ }^{103}$ Op. Cit., p. 63
} 
carecem de valor universal. Sofrem demasiada interferência de acontecimentos acidentais para que suas impressões possam sempre alcançar o grau máximo de profundidade. A filosofia e a reflexão atingem a universalidade e penetram na essência das coisas, mas atuam apenas naqueles cujos pensamentos chegam a adquirir a intensidade de uma vivência pessoal. Disso resulta que a poesia tem vantagem sobre qualquer ensino intelectual e verdade racional, bem como sobre as meras experiências acidentais da vida do indivíduo. É mais filosófica que a vida real (....) mas é, ao mesmo tempo, pela concentração de sua realidade espiritual, mais vital do que o conhecimento (reflexivo e) filosófico. ${ }^{104}$

Com a virtude e a felicidade deslocando-se para o interior do homem, a arte é chamada a reproduzir não somente a beleza sensivel, mas também, ao penetrar no mundo do invisivel, aspirar à expressão do ser moral como propōe Sócrates. ${ }^{105}$

Esse mundo invisivel, o mundo da alma, e sua adequada sensibilização e ordenação implica ainda um outro sentido que nos interessa que está afeito ao conceito de epõde ${ }^{106}$. Freqüente na literatura grega desde a Odisséia de Homero enquanto rito terapêutico, a epõde como ensalmo mágico ganha em Platão um sentido metafórico objetivando enfatizar a capacidade sugestiva da palavra humana, a epõde como palavra que persuade, convence. Enquanto "expressão funcional" adequada à natureza do objetivo buscado, essa epõde-belo discurso ou epõde-mito, "não somente atua sugestivamente quando o ouvinte nela acredita, mas, pela própria virtude natural de sua forma e de seu conteúdo (entonação musical, índole e significação de seu texto) ela é capaz de suscitar de modo persuasivo na alma de quem a escuta, uma nova crença, ou de tomar mais intensas as crenças que intimamente já existiam". Sendo "encantadora", nos dois sentidos da palavra, ela traz serenidade, esclarecimento e ordenação à alma, e ao corpo, de quem ouve, e isso tanto pela virtude própria do que

\footnotetext{
104 Op. Cit., p. 63

${ }^{105}$ Op. Cit., p. 536

${ }^{106}$ As reflexōes que seguem, referentes ao conceito de epóde e seus desdobramentos, procedem do ensaio de Gracia Guilen D., A psicoterapia verbal na obra de Platão, doc fotocopiado.
} 
está sendo dito quanto pela disposição pessoal de quem ouve, que é relativa à ordenação própria que nele habita potencialmente.

Observe-se que de maneira alguma Platão pensa que a ação 'encantadora' de um belo discurso ou de um mito possa ser completamente inteligível mediante o uso da razão. O belo discurso e o mito, diferentemente do 'argumento' racional, operam sobre a alma nela suscitando persuasōes e por fim crenças, as quais nunca podem ser inteiramente reduzidas à estrita razāo. É desse modo que, ao referir-se à produção poética, Platão qualifica suas odes como epodos, ou seja "exortações dirigidas à alma de quem as escuta, para que sob o encanto da forma assimile docilmente, como um remédio açucarado, o conteúdo sério que encerram." 107

Estendendo esse raciocínio ao tema mais geral da saúde humana, podemos dizer que a "saúde anímica de um homem, condição de sua saúde somática, consiste, portanto, na ordenação correta das duas partes principais de sua alma: aquela em que predomina o racional e lógico, modificável pela ação da dialética e aquela em que predomina o irracional, a crença, suscetivel de educação ou psykhagõgia (Fedro, 261, a 273 c), através da ação do encanto persuasivo da epõde, o 'belo discurso' ou o 'mito". Nesse sentido, "...uma epõde será filosoficamente aceitável e medicamente eficaz quando alcance a condição de lógos kalós, 'belo discurso' e quando o enfermo o receba depois de haver 'oferecido', 'entregado' ou 'apresentado sua alma".

Sendo óbvio que essas proposições não contemplam qualquer produção literária/poética de qualquer tempo, nossa escolha recaiu sobre extratos das obras de Fernando Pessoa (1888-1935) e de Rumi (século XIII). 
Que a obra de Fernando Pessoa atenda aos preceitos mencionados, para além do que seus próprios versos nos mostram, encontramos menção em suas Palavras de Pórtico, apresentadas logo na abertura do livro:

"Navegadores antigos tinham uma frase gloriosa: 'Navegar é preciso, viver não é preciso.'

Quero para mim o espínto [d]esta frase, transformada a forma para a casar com o que sou: Viver não é necessário; o que é necessário é criar.

Não conto gozar a minha vida; nem em gozá-la penso. Só quero tomá-la grande, ainda que para isso tenha de ser o meu corpo e a (minha alma) a lenha desse fogo.

Só quero tomá-la de toda a humanidade; ainda que para isso tenha de a perder como minha.

Cada vez mais assim penso. Cada vez mais ponho na essência anímica de meu sangue o propósito impessoal de engrandecer a pátria e contribuir para a evolução da humanidade.

É a forma que em mim tomou o misticismo de nossa raça."

Palavras que parecem expressar com lucidez um sentimento profundo de quem, segundo sua apresentadora Maria Aliete Galhoz, "tende já para a imortalidade" mesmo se permeiam o paradoxo se nos lembramos da ironia e grande ceticismo que, em alguns versos, demonstra ele sobre esse assunto que tem mais a ver com a mitificação. Por exemplo:

"Nada que sou me interessa./ Se existe em meu coração/ Qualquer cousa que tem pressa / Terá pressa em vão.

Nada que sou me pertence / Se existo em que me conheço/ Qualquer cousa que me vence/ Depressa a esqueço.

Nada que sou eu serei./ Sonho, e só existe em meu ser,/ Um sonho do que terei/ Só que o não hei de ter."

(Poesias Coligidas/Inéditas 1919-1935 [753])

107 Jaeger, W., op. Cit. p1323. 
Ou ainda:

"Eu tenho idéias e razões,/ Conheço a cor dos argumentos/ E nunca chego aos corações".

(op. Cit., [731])

E também, fortalecendo uma dimensão que ultrapassa os limites do pensamento:

"As nuvens são sombrias /Mas, nos lados do sul, /Um bocado do céu EE tristemente azul.

Assim, no pensamento, /Sem haver solução, /Há um bocado que lembra /Que existe o coração.

$E$ esse bocado é que é /A verdade que está /A ser beleza eterna/ Para além do que há".

(op. Cit. [712]).

Seria esta uma mostra do que Galhoz chama de

(...) severa lucidez ou indisciplinadora acusação das suas palavras públicas, o humanismo da sua compreensão e da sua solidariedade particulares, e a inabdicada independência e dignidade - para lá das formas, das modas, das estéticas e de seus próprios erros - da sua obra. ${ }^{108}$

Rumi (séc. XIII), por seu lado, é considerado o maior poeta místico de toda a tradição persa e árabe. Pertence, como diz um de seus comentadores, 'à seleta galeria daqueles que foram capazes de penetrar simultaneamente as esferas do divino e da criação poética,109 - San Juan de la Cruz, Santa Tereza de Ávila, Dante, Kabir, Al-Hallaj, entre outros.

\footnotetext{
${ }^{108}$ Fernando Pessoa, Obra Poética, RJ, Ed. Nova Aguilar S.A., 1997, Introdução Geral, p. 43.

${ }^{109}$ Carvalho, José Jorge, Introdução ao Divan de Shams de Tabriz, Attar Ed., São Paulo, 1996, p.11.
} 
Impressiona o volume de sua produção literária, com o total de suas odes ultrapassando os 40.000 versos - o que faz pensar que tenha escrito sua obra poética diariamente ao longo de quinze anos, até começar a compor seu Masnavi. ${ }^{110}$ Rumi, entretanto, começou a ser conhecido no Ocidente somente no inicio do séc. XIX, a partir de traduções alemãs e inglesas. As primeiras acabaram por influenciar Goethe a escrever seu "Divan do Ocidente e do Oriente', em 1815, onde chega mesmo a parafrasear Rumi. Também Freud, em seu ensaio sobre um caso de paranóia (o Presidente Schreber), se utiliza de um dos poemas de Rumi para caracterizar o papel no homem do que, em alguns momentos, ele denomina como fixações libidinais:

"Lá onde nasce o verdadeiro amor/morre o 'eu, esse tenebroso déspota.Tu o deixas expirar no negro da noite/e livre respiras à luz da manhã." $" 11$

Cabem perfeitamente nesta tese algumas indicações de Rumi, em prosa e verso, que se coadunam com o espirito deste trabalho e indicam o ponto a que aspiro ao integrar o discurso intelectivo ao uso destes materiais:

"Procurai não dizer que entendestes... A compreensão reside em não compreender... Para ti essa compreensão é um obstáculo. É preciso escapar dela.' Para alcançar o sentido profundo dissimulado 'sob o véu das palavras', somente disponibilidade, ou receptividade não bastam: é necessánio um esforço, uma atitude, primeiro passo que faz daquele que questiona - ou se questiona - um peregrino no Caminho. 'Como poderiamos alcançar a pérola simplesmente olhando para 0 mar? É preciso um mergulhador para encontrar a pérola. ${ }^{\prime 112}$

"Atenta (enfim) para as sutilezas que não se dão em palavras, compreende o que não se deixa capturar pelo entendimento".

Sobre o significado dos Contos de Ensinamento cabe uma pequena digressão:

\footnotetext{
110 opus.cit., p.38

${ }^{111}$ Freud, S, Notas psicanalíticas sobre um relato autobiográfico de um caso de paranóia (Dementia Paranoides), RJ, 1969, p. 88. A tradução brasileira apresenta diferenças: "Pois quando as chamas do amor se alçam,/Então o Eu, o sombrio tirano, morre."

${ }^{12}$ Prefácio de Eva de Vitray-Meyerovitch ao Fihi Ma Fihi de Rumi, tradução brasileira de Margarita M.G. Lamelo, para as Ediçōes Dervish, RJ, 1993, p. 9.
} 
"certos segredos se escondem em palavras" (I. Shah).

"um conto, fictício ou não, ilumina a verdade".

(Rumi)

Entre todos os instrumentos que, século após século, tem sido utilizados, tanto no Oriente quanto no Ocidente, como veículo de conhecimento, os Contos de Ensinamento mantêm um papel preponderante. De fato, no Oriente se diz que existe uma quantidade enorme de conhecimento valioso escondido nesse tipo de literatura, que entre nós ficou conhecida na forma de fábulas, lendas, contos, etc, e isso desde pelos menos os trabalhos de Esopo, há 2700 anos atrás.

Esses materiais encarnam tendências do ser humano na forma dos personagens e situações dos contos, que estabelecem um paralelo consistente e produtivo de certos estados mentais. Seus símbolos são os personagens dos contos cuja forma de conduzir-se sugere a certas áreas da mente a maneira como a consciência humana às vezes se comporta.

Diz-se dessa literatura que ela é multifuncional tendo sido expressamente concebida para conseguir tocar a parte mais profunda, mais escondida do ser humano, parte essa que não pode ser atingida por nenhum outro procedimento. Isso de tal maneira que, enquanto nos deixamos entreter pelos coloridos atributos de princesas, gênios bons e maus, e cavalos mágicos, algo mais está sendo trabalhado no mais profundo de nossas mentes. ${ }^{113}$

Mas do que exatamente estamos falando? Que parte seria essa que valeria a pena buscar? 
Há uma história nas fábulas de Esopo que nos ajuda a compreender essa questão conforme discorre Shah ${ }^{114}$. Trata de uma jovem toupeira que foi procurar a mãe para dizer-Ihe que podia enxergar. Ora, como se sabe, as toupeiras tradicionalmente carecem de visão. Sua mãe então decidiu pô-la à prova colocando diante dela um pouco de olíbano (espécie de incenso), perguntando-Ihe o que era. "Uma pedra" - respondeu a toupeirinha. "Você não somente é cega - concluiu a māe - mas também perdeu o sentido do olfato".

Uma interpretação apressada que se contenta com o sentido mais evidente e superficial da história levou vários intérpretes a encontrar uma moral do tipo: "é fácil desmascarar um impostor". Se lembrarmos, no entanto, que a língua árabe constitui a fonte real da versão semítica de onde provêm as histórias de Esopo, teremos uma chave para penetrar em seu sentido oculto. Assim, "toupeira" em árabe (khuld, do radical KHLD) escrevese do mesmo modo que khalad, que quer dizer "eternidade, paraíso, pensamento, mente, alma", conforme o contexto. Escrita originalmente de uma forma poética em uma língua semítica, ao ser traduzida para o grego no século VII a.C., essa palavra, e a história, parecem ter perdido sua riqueza.

Por que a menção à pedra e ao cheiro? Porque na tradição, Moisés (guia do seu povo) é aquele de quem se diz ter "tornado a pedra tão perfumada quanto o almiscar. Acontece que Moisés simboliza um pensamento orientador, que transforma algo aparentemente inanimado e inerte em algo "tão perfumado quanto o almíscar" - algo dotado de uma vida que se pode quase chamar própria.

À luz dessas consideraçōes, a historieta mostra agora que a "mãe" do pensamento (sua origem, matriz, qualidade essencial) apresenta o olíbano (experiência impalpável) ao seu "filho", o pensamento, ou mente na tentativa

\footnotetext{
${ }^{113}$ Prefácio de Doris Lessing - in “Chercheur de Vérité", Shah, I., Albin Michel, Paris, 1984.

${ }^{114}$ Shah, I, - Os Sufis, Ed. Cultrix, SP, 1993, p. 37/8/9.
} 
de desenvolvê-lo. $O$ indivíduo (a toupeira), porém, ao concentrar-se na "visão", tentando desenvolver suas faculdades em uma ordem errada, chega até a perder o uso daquelas que deveria ter. ${ }^{115}$

Podemos pensar assim, que o ser humano em vez de esforçar-se para alcançar o próprio interior a fim de desenvolver-se, tende a procurá-lo fora de si, perseguindo ilusōes que, na verdade, o paralisam.

Dai a importância da busca interior de que fala Doris Lessing, busca essa que tem nos contos de ensinamento um veículo privilegiado.

\section{A alegoria do pêssego}

Podemos compreender um pouco melhor ainda os contos de ensinamento usando a imagem de um pêssego, que tem beleza, substância e profundidade escondidas - o caroço. Uma pessoa pode sentir-se emocionalmente envolvida pelo exterior; rir-se de uma piada ou apreciar a beleza. Mas isso é apenas como se o pêssego nos tivesse sido emprestado. Permanecendo nesse patamar, tudo o que realmente se absorve é a forma e a cor, talvez o aroma, o formato e a textura.

Podemos, no entanto, dar um passo além, comer o pêssego e experimentar mais um prazer - compreender-lhe a profundidade. $O$ pêssego, assim, contribui para a nossa nutrição, torna-se parte de nós mesmos. Podemos jogar fora o caroço - ou quebrá-lo e encontrar dentro dele uma amêndoa deliciosa. Esta é a profundidade escondida. Tem sua própria cor, tamanho, forma, profundidade, gosto, função. Podemos juntar as

${ }^{115}$ Shah, I., Chercheur, p. 37. 
cascas dessa noz e, com elas, alimentar o fogo. Ainda que o carvão já não tenha nenhuma utilidade, a parte comestivel passou a fazer parte de nós. ${ }^{116}$

Voltemos à idéia de que o conto de ensinamento pode ser considerado como um paralelo consistente e produtivo de certos estados mentais ou uma alegoria desses estados. Tomando o conto Os Cegos e o Elefante, no qual um grupo de cegos é levado a conhecer um elefante e cada um deles acaba "conhecendo/apalpando" somente uma de suas partes - que ele toma pelo todo - observamos no nivel mais baixo possivel de interpretação que ele ridiculariza a ciência e aos acadêmicos que tratam de explicar as coisas unicamente com a ajuda de evidências que são capazes de mensurar e de nenhuma outra maneira. Em um sentido religioso, pode-se dizer que a história nos conta que Deus está em todos os lugares e em todas as coisas. O homem é que daria diferentes nomes a coisas que the parecem existirem separadamente, mas que, de fato, fazem parte de um todo mais vasto que ele não pode perceber, seja porque é cego ou porque não há luz.

Em outro sentido e no mesmo nivel, esta história é humoristica, pois nos faz rir da estupidez das pessoas que se apóiam sobre evidências muito escassas; ainda, se a tomamos como ensinamento filosófico, ela mostraria que o homem é cego e que se esforça em determinar algo que, de fato, é demasiadamente grande para ser medido com seus instrumentos inadequados.

Em suma, do ponto de vista do próprio conto de ensinamento, nenhuma das pessoas que tentaram interpretá-lo de uma ou de outra maneira podem saborear um conto interior, nem sequer podem imaginar que ele existe. $^{117}$

\footnotetext{
${ }^{116}$ I. Shah, Os suris, p. 105.

${ }^{117}$ Consideraçōes desenvolvidas em Sufismo en Occidente, Anônimo, Ediciones Dervish international, B.Aires, pp. 20-21
} 
"Nasruddin passava todos os dias por uma fronteira com seu burro carregado de caixas, objetos e outros pertences dos mais variados tipos. Como nesse lugar era muito freqüente a prática do contrabando, os guardas da fronteira tornaram-se especialistas em descobrir esconderijos e flagrar os contraventores. Certos de que Nasruddin não seria diferente, a cada dia examinavam exaustivamente a bagagem do burro; reviravam sua carga, desmontavam peça por peça, mas nunca achavam nada que pudesse ser classificado como contrabando. Passados muitos anos, um desses guardas, já aposentado, encontrou-se com Nasruddin. Perguntou-lhe então qual era a natureza de seu contrabando, já que afinal sabia que ele o fazia como todos os outros. Nasruddin respondeu então que contrabandeava burros."

Podemos dizer, com Machado, que na busca das origens, da difusão e de uma possivel explicação, vasculhamos os conteúdos de um C. de E. como guardas de fronteira. Enquanto classificamos, comparamos, isolamos motivos, elaboramos explicações psicológicas, filosóficas, ou outras, os "burros" passam pela fronteira do entendimento... ${ }^{118}$

De fato, não é necessário para a eficácia do processo de transmissão dos Contos de Ensinamento que eles sejam compreendidos de início. Pois essa compreensão seria, na verdade, uma pseudocompreensão, prematura e estéril. Seria uma tradução para nossa linguagem desgastada e ineficaz, no que respeita essa dimensão, de uma mensagem escrita em uma linguagem poética - aquela dos simbolos e dos arquétipos.

O trabalho de assimilação que se produz em nós, se nos contentamos de ler, parece obedecer a suas próprias leis. A análise química dos elementos constituintes do pão não alimentará aquele que tem fome. "Comer é insubstituivel", diz I. Shah. ${ }^{119}$ Na verdade,

"Somente aquele que experimenta conhece".

\footnotetext{
${ }^{118}$ Prefácio de Regina Machado a " O Jardim e a Primavera" de Amir Khusru, Attar Editorial, SP, 1993, p. 16
} 
Já de um ponto de vista psicanalítico, que será tratado com mais detalhes adiante, esse modo de proceder que pretende fazer interagir o discurso racional e o simbolismo e mensagem presentes em uma obra de arte, guarda semelhanças com a compreensão dos conceitos de inconsciente e o modo de comunicação com essa dimensão postulado pela Psicanálise (discutido nas sessões posteriores). Neste momento, um de seus textos em particular destinado a aconselhar aos médicos que exerciam a Psicanálise, presta-se melhor a esse empreendimento. Nele encontramos o conceito de "atenção flutuante", descrito por Freud como a atitude fundamental do analista na verdadeira escuta de seu paciente e correspondente à regra da "livre associação" que the é proposta. Consiste ela no engajamento ativo, ao mesmo tempo, de sua atenção e de seu inconsciente, no esforço de compreensão do que o paciente quer dizer, para além das palavras e do sentido enunciado, desgarrado de seus préjulgamentos conscientes e mesmo de suas defesas inconscientes. Somente assim 0 analista conseguiria conectar-se, via inconsciente e através de processos interpretativos, com a verdade do paciente que, justamente, considera-se residir em seu inconsciente.

O analista, "deve colocar-se em posição de fazer uso de tudo que the é dito para fins de interpretação e identificar o material inconsciente oculto, sem substituir sua própria censura pela seleção da qual o paciente abriu mão" diz Freud a seus pares médicos. ${ }^{120}$ - que serão alvo de suas críticas no texto sobre 'Análise Selvagem'. É certo que essa atitude depende absolutamente do trabalho de análise do analista ele mesmo, de maneira a que não prevaleçam, ainda que existam, "pontos cegos" em sua percepção. Assim, o progresso de um tratamento depende muito do analista permitir-se ser "tomado de surpresa", mesmo que deva ele esgrimir competentemente seus conceitos teóricos. De todo modo, é interessante notar, em acordo com

${ }^{119}$ Shah, I., Caravane de Reves, Le Courrier du Livre, Paris, 1978, p. 9 e 110. 
nosso procedimento de apresentação desta tese, a significação e importância atribuídas por Freud ao processo analítico assim descrito, no curso do qual "obtêm-se impressões e conviç̧ões que em vão seriam buscadas no estudo de livros e na assistência a palestras". ${ }^{121}$

Para fechar essa digressão podemos dizer que, funcionando como uma ilustração dos raciocínios desenvolvidos no decorrer do texto, os poemas, contos, provérbios, mitos mencionados fazem parte integrante da argumentação de cada tópico desta tese. Com isso quero significar que esses materiais não são acessórios, nem mesmo constituem eles meros elementos embelezadores, para dizer numa perspectiva estética rasteira. Ao contrário, tentamos aproximar-nos, isso sim, da função mais alta que thes caberia incorporar enquanto expressão artística, como o propõe Sócrates. As artes, diz ele, não deveriam contentar-se "apenas em reproduzir a beleza corpórea, mas (deveriam) também aspirar a transmitir a expressão do ser moral do homem". ${ }^{122}$

${ }^{120}$ Freud, S., "Recomendaçōes aos médicos que exercem a Psicanálise" (1912), Imago, RJ, 1969, p. 154 e seguintes.

121 Op. Cit. p. 155

122 Op. Cit. p. 155 


\section{UM PARADIGMA EXISTENCIAL PARA A PROMOÇÃO DA SAÚDE}

Continuamos neste ponto o estudo do que estamos chamando de paradigma existencial para a Promoção da Saúde com o objetivo de descrever e aprofundar a análise das duas estruturas que consideramos paradigmáticas no caminho de desenvolvimento humano: Alienação/Heteronomia e Liberdade/Autonomia. Esperamos assim, de forma tentativa, constituir uma base fecunda para a reflexão e a prática, na medida em que sejam esclarecidos alguns temas que tem importância capital em qualquer intervenção. Com efeito, a percepção do que chamamos "paradigma existencial", do modo como o visamos, pede a discussão do significado da liberdade/autonomia e das condiçōes necessárias à sua efetivação em um ser humano, o que, por sua vez, implica o reconhecimento das condiçōes em que se pode verificar sua alienação/heteronomia. Essas questões serão tratadas através das noções de História, Alienação e Liberdade enquanto categorias filosóficas que funcionem como termos de referência para a prática.

O exame mais minucioso dessas estruturas ganha sentido na medida em que o alcance possível da ação de um programa de promoção da saúde, o "lugar" a chegar como dizíamos antes - enquanto termos de referência que balizam o trabalho - deve estar claro para qualquer pessoa que realize uma intervenção junto a um grupo (no caso analisado, de adolescentes), sob pena de provocar um hiato, uma lacuna na percepção das pessoas com as quais se está trabalhando que se mostre intransponivel ou no mínimo não identificável, incompreensivel, e, portanto, confuso - e, se temos em mente os problemas já enfrentados por um adolescente no ato mesmo de "adolescer", ademais em situação de vulnerabilidade social, quem precisa de mais confusão? 
Senão vejamos, à par de um conjunto de informações acerca do uso e abuso de "drogas", sexualidade/DST's, etc., um programa de promoção da saúde nessa área propöe necessariamente, implicita ou explicitamente, um "outro lugar" para que o adolescente ocupe - distinto daquele em que se encontrava até então. Trata-se de "lugares" existenciais, projetos existenciais que estão em jogo, imprimindo à vida do sujeito uma ou outra direção - não polarizadas necessariamente entre o bem e o mal, mocinho e bandido, mas que, de qualquer modo, pretendem encarnar uma opção que se considera sadia, que represente um progresso intra-individual, social, de consciência política, e, dito em nossa perspectiva, um progresso existencial na vida das pessoas com as quais se está interagindo. Aludimos aqui ao sentido proposto logo no inicio de nossas considerações através de Shah OA., que para caracterizar esse progresso nos remete ao "grau de consciência que temos de nossos pensamentos e reações, da consciência de nossas tendências, nossos pontos fortes e nossas fragilidades, da consciência ou inconsciência acerca da massa de condicionamentos que carregamos ${ }^{n 123}$; nos propondo depois visar essa consciência de nossos pensamentos e reações, de nossas tendências, nossos pontos fortes e nossas fragilidades e deslocar, assim, o teatro das automáticas re-açōes e dar lugar ao que podemos chamar de reação refletida. Em outra perspectiva, Dolto $F$. vê esse progresso associado a uma busca, pelo adolescente, da realidade, dos outros seres humanos, de seu apoio, sua camaradagem, do amor que o sustentará e o ajudará a não cair nas armadilhas da dependência - quimica/existencial.

De todo modo, essas e outras visões presentes neste trabalho acerca do que seja esse progresso a ser alcançado por um ser humano, em nosso caso adolescente, permanecem em harmonia com o esforço pedido por Platão de conformação interior da alma individual em torno de uma ordenação que, na verdade, corresponde à sua própria essência, seu próprio cosmos. Em acordo com essa ordem, cada uma das partes da alma,

\footnotetext{
${ }^{123}$ In Une apprentissage du sourisme, Guy Trédaniel Editeur, Paris, 2001, p. 34
} 
obedecendo a uma hierarquia termina por fazer o que "Ihe compete tomando - Homem capaz de dominar-se e de congraçar numa unidade a multiplicidade contraditória das suas forças intemas"124

Em termos de um programa de promoção da saúde, o tratamento preciso dos termos de referência que utilizamos relaciona-se ao cuidado que devemos tomar para atuar com clareza e firmeza de propósitos. Nesse sentido, cabe também uma referência à História como forma de esclarecer a complexa maneira pela qual a práxis se concretiza na vida de cada indivíduo, que, como colocado na discussão metodológica, entendemos como fruto de um encadeamento que não se esgota num feixe de impulsos interiores ou conjunto de forças exteriores determinantes que agiriam de modo independente em relação à própria história do sujeito e de sua ação no mundo - o que ele faz com aquilo que dele fizeram. A História, nessa perspectiva, nos aparece como categoria que permite celebrar a vida humana em toda a sua extensão: um processo cujas determinaçōes seriam guiadas por um conjunto de significações, motivações e valores, adquiridos/passados via sistema socioeconômico/cultural que, ao sedimentar-se num indivíduo em particular, em primeiro lugar pela mão (e a palavra) daqueles que o conceberam - sejam esses pais presentes ou ausentes, literal ou simbolicamente falando - pode reformular-se, condensar-se, adquirir novas formas/novos conteúdos, em maior ou menor grau, por força de sua função simbólico-criadora na expressão de Ernest Cassirer.

Em tal contexto, a atitude dos indivíduos explicita-se - de maneira consciente ou inconsciente - como mediação necessária da ação de forças à primeira vista a ela exteriores (sejam elas de fundo econômico, religioso, político, científico...), e que terminam por constituir-se na própria "intersecção de minhas experiências" mas também "na intersecção de minhas experiências com as experiências de outrem, pelo encadeamento de

124 in Jaeger,W., op. Cit. p. 811. 
umas sobre as outras e destas com o mundo real". ${ }^{125}$ Nossas escolhas, portanto, estariam inextricavelmente ligadas a um processo histórico que certamente nos ultrapassa - pois ele condensa em cada um de nós diversas formas de condicionamentos sócio-culturais, políticos, científico/religiosos, corporais,... - mas que ao mesmo tempo pode ser por nós ultrapassado.

Daí a referência às categorias de Alienação e Autonomia que quer introduzir a discussão aprofundada das duas dimensões nas quais elas são engendradas:

- a dimensão "objetiva" - onde trabalharemos com a noção de forma histórica, para descaracterizar a alienação e/ou a liberdade existentes no campo social como fatalidades.

- a dimensão "subjetiva-individual" - onde mais uma vez discutiremos a noção de crescimento/evolução possivel da consciência individual através dos conceitos da Psicanálise e da refiexão filosófica.

Essa divisão entre duas dimensões aparentemente dissociadas não nos serve senão a título de quadro de referência, uma vez que, como o salienta Castoriadis ${ }^{126}$, existe sempre homologia e correspondência profunda entre a estrutura da personalidade e o conteúdo da cultura, não havendo, pois sentido algum em pré-determinar uma pela outra.

\footnotetext{
${ }_{125}^{125}$ Merleau-Ponty, M. La Phénomenologie de la Perception, p. XV.

126 Castoriadis, C. p. 38. L'Instituition Imaginaire de la Societé - Seuil, Paris, 1975 ; vale lembrar que Kardiner, A., por sua vez, trabalhou essa mesma questão de maneira bastante profunda no seu 'La Structure de la Personnalité'.
} 


\section{O sentido profundo da alienação na dimensão subjetiva}

O referencial teórico, a partir do qual tentaremos identificar o significado maior da alienação procederá em grande medida da teoria psicanalítica, e devemos explicar a razão dessa escolha. Não se trata aqui de privilegiar as categorias da Psicanálise, em detrimento da teoria política ou sociológica. Trata-se sim de valorar adequadamente o sujeito da ação social sem, entretanto, cair no chamado "desvio psicologista", uma vez que "a psicanálise não pode substituir a sociologia nem sequer extrair de si própria uma teoria social ${ }^{127}$. Porém, mesmo se restringirmos o uso do método psicanalítico à explicação do psiquismo humano, é forçoso conceder que, para determinadas questōes, a sociologia e a psicanálise podem entrar em relação. Efetivamente, "a sociologia não pode renunciar à psicologia quando se trata de questões como, por exemplo, a chamada atividade subjetiva ou a formação de ideologia". 128

Outros autores levantaram a mesma problemática, como Laing, Sartre e Fromm, por exemplo, chegando mesmo a trabalhar não somente com a teoria, mas também com a técnica psicanalítica, freudiana e pós-freudiana, e este será o nosso caso. Temos ciência de que tal atitude não pode ser revestida de garantias epistemológicas "eficientes" (?) que a priori permitissem evitar o psicologismo, mas acreditamos que o risco valha a pena.

De qualquer modo, face à complexidade da temática a ser tratada, esta abordagem parece mostrar-se como muito apropriada do ponto de vista de sua capacidade para dar conta da interseç̧ão de dois campos de fenômenos com os quais nos defrontamos: aquele que pertence ao campo dos fenômenos e processos sociais e o da subjetividade individual. Isto num

\footnotetext{
${ }^{127}$ Reich, W. A aplicação de Psicanálise à investigação social, in Psicanálise, Fatores Sócio-Políticos, RES, Porto, p. 69.

${ }^{128}$ Id ibid
} 
esforço que permita detectar algumas das mediações entre os diversos niveis de contexto, dos menores sistemas microssociais aos maiores sistemas macro sociais, como o propõe Laing ${ }^{129}$, estudando os sistemas intermediários situados dentro desse limite, na medida da importância que eles têm para este trabalho, compreendendo-os como um meio condicionador e condicionado entre as partes individuais do todo.

Trata-se de usar como uma das ferramentas de análise uma disciplina que tem 'a pretensão de subverter uma formulação de base do pensamento ocidental que se quer científico. A ironia aqui tem a ver com a inversão de uma proposição fundamental de Bacon (Roger), em função da qual a ciência e seu establishement apostam no poder/força de argumentos racionalmente elaborados, pretendendo com isso encontrar e submeter-se à lógica de leis entendidas como naturais, seja do mercado, da matéria, da sociedade, do espirito... De fato, no seu Opus Maius (1268), esse frade franciscano que lançou as bases do trabalho cientifico propunha, com efeito, haver "dois modos para adquirir o conhecimento, um através do raciocínio e outro através da experiência. $O$ raciocinio atinge uma conclusão e nos obriga a concede-la, mas não provoca certeza nem elimina dúvidas, de maneira a permitir à mente repousar na verdade, o que somente pode ser proporcionado pela experiência". ${ }^{130}$

Estamos aludindo à formulação encontrada num certo discurso acerca do método já há 400 anos, que, desde então, e contrariamente até àquele que em sua condição de cristão a celebrizou, mantém a pretensão de

\footnotetext{
${ }^{129}$ Laing, R.D. 'O óbvio', in Dialética da Libertação, Zahar, Rio, p. 16.
}

130 In "On experimental science", 1268, Medieval Sourcebook, www.fordham.edu/halsall/source/bacon $2 \mathrm{html}$. A ciência moderna, nas palavras de Shah, I. (Os sufis, 1987, Pensamento), em lugar de aceitar a idéia da necessidade da experiência em todos os ramos do saber, tomou a palavra no sentido de "experimento", no qual o pesquisador permanece fora da experiência. Esta postura tem impedido os pesquisadores de aproximar-se do conhecimento por meio do próprio conhecimento, quer dizer partindo da própria experiència e nāo somente do experimento (dando lugar à razão instrumentalizada a que alude Habermas, por exemplo, no seu "La Science et la Tecnique comme Ideologie) 
subsumir o Ser ao pensamento comprimido nos limites da razão: "Penso, logo sou" (cogito ergo sum).

Essa miragem que torna o homem moderno tão seguro de si mesmo no próprio seio de suas óbvias e decantadas incertezas sobre esse tal "si mesmo" - acabou tomando outra forma nas elucubrações psicanaliticas lacanianas que nos servem de base. Duas proposiçōes convergentes tomaram seu lugar. Primeiro, o cogito foi quase invertido, pois, na perspectiva psicanalítica, na verdade "penso quando não sou, (portanto) sou quando não penso". Esclarecendo melhor, porém, Lacan propõe que: "eu não sou, quando sou o joguete de meu pensamento; e penso no que sou, quando não creio estar pensando ${ }^{\text {131 }}$. Uma dimensão que se faz sentir continuamente como alguma outra coisa, em tantas experiências que os homens vivem, não sem pensar nelas, em absoluto, ao contrário pensandoas, mas certamente sem pensar que as pensam.

Trata-se assim, da validação de uma outra lógica possível para podermos pensar o humano que atua pelo deslocamento do eixo de referência no ato de conhecer, dirigindo a percepção para "uma outra cena ${ }^{\text {132 }}$ que não aquela a que estamos acostumados na lida cotidiana menos explícita, sem, entretanto, nada perder em realidade. Os versos de Juan de la Cruz, o santo, expressam bastante bem uma das caracteristicas fundamentais que se apresentam nesse caminho:

Para vir ao que não sabes - hás de ir por onde não sabes Para vir ao que não gostas - hás de ir por onde não gostas Para vir ao que não possuis - hás de ir por onde não possuis Para vir ao que não és - hás de ir por onde não és.

Para vir a saber tudo - não queiras saber algo em nada

Para vir a saborear tudo - não queiras saborear algo em nada

\footnotetext{
131 Lacan, J., Écrits - L'Instance de la Lettre dans I'Inconscient', p. 516-517, Ed. Du Seuil, Paris, 1966.

${ }^{132}$ Essa é a expressão usada por Freud para caracterizar o inconsciente em alguns de seus escritos que iniciam sua obra.
} 
Para vir a possuir tudo - não queiras possuir algo em nada

Para vir a ser tudo - não queiras ser algo em nada.

(San Juan de la Cruz - Escritos Espirituais, "Monte de Perfeição", Sopé do Monte, Obras Completas, Ed Martins Fontes, SP, p.88)

\section{Principais pontos de referência para a construção de um "paradigma existencial" para a promoção da saúde na perspectiva da Psicanálise em sua análise da Alienação.}

Levando em conta os questionamentos anteriores, queremos partir da interrogação proposta por Aristóteles em sua Ética a Nicômaco abordando a questão, justamente, da ciência que um homem pode chegar a possuir de si mesmo - o que representa uma outra maneira de expressar um dos aspectos de nossa problemática. Preocupa-se ele com a relação entre julgamento (reto) e uma conduta que, como se observa invariavelmente, não acompanha essa retidão. "Como é possivel, pergunta ele, que um homem que julgue com retidão mostre-se incontinente em sua conduta. Alguns afirmam que tal conduta é incompativel com o conhecimento, pois seria estranho (...) que, existindo o conhecimento num homem, 'alguma coisa pudesse avassalá-lo e arrastá-lo após si como um escravo'." ${ }^{133}$ Claro está que ele supõe, logo na primeira página da Ética, que o que é buscado em toda escolha e ação humanas é um certo bem - no mais das vezes, invisível para aquele que os pratica - e que sua realizaçäo prática depende da relação intrínseca existente entre virtudes intelectuais e virtudes morais, ambas temperadas pela racionalidade própria aos seres humanos.

Imediatamente podemos de nos remeter à interpretação possibilitada por Platão que enfatiza ser o conhecimento do bem não uma operação dependente da inteligência, mas sim "a expressão consciente de um ser interior do homem", deitando raizes numa "camada profunda da alma em

${ }^{133}$ Ética a Nicômaco, Aristóteles, ref. 1145b, 25. 
que já não se podem separar, pois são essencialmente uma e a mesma coisa, a penetração do conhecimento e a posse do conhecido"134. Trata-se de uma alusão ao Homem no homem, como o nomeia Platão para distinguir a direção que deve tomar a formação/a Paidéia: desenvolver o Homem que reside dentro do homem. (República, 588 E, 589 B)

Estimulados à reflexão poderiamos propor, como resposta tentativa ao desvio apontado por Aristóteles, a mesma perspectiva platônica d'A República, quando Platão adverte que aquele que preza a injustiça passa o comando de sua vida para a besta selvagem e multicéfala que existe em nós. Mas o leão, imagem recorrente, se bem domado, submete-se ao Homem que há dentro do homem e o ajuda a triunfar na luta contra essa hidra. ${ }^{135}$ Trata-se de fundar o império do verdadeiramente humano que subjuga o infra-humano, o império do superior sobre o inferior em nós, criando um reino que nada mais faz senão explicitar nossa própria natureza interior. $^{136}$

Se nos destacamos, porém, ao mesmo tempo, do auto-sustentado sistema aristotélico e da realidade profunda desvelada por Platão, podemos legitimamente manter a questão acerca dessa "coisa" que teria o poder de avassalar e arrastar um homem após si, contra a sua vontade, na condição de escravo. A manutenção em suspensão dessa interrogação nos servirá como cenário para as reflexões que seguem envolvendo a perspectiva psicanalítica em torno desse mesmo tema.

Freud, na "Nova Série de Lições de Introdução à Psicanálise", propunha como objetivo maior da análise o reforço do Eu em relação ao Superego, e assim, "tomando-o mais independente do superego (conseguir) alargar seu campo de visão e estender sua organização de tal forma que ele (o Eu) pudesse se apoderar de novas regiōes do ld. Onde estava o ld o Eu

\footnotetext{
${ }^{134}$ Jaeger, W., op. Cit, p. 565

${ }^{135}$ op. cit., p. $972-3$
} 
deverá advir ${ }^{137}$. Assim, como o explica Freud em outro texto, a cura psicanalítica seria fundada sobre a influência exercida pela consciência (Eu) sobre o inconsciente (Id) ${ }^{138}$.

O Eu é entendido psicanaliticamente como o Eu consciente, o Id por sua vez quer representar o inconsciente na sua acepção mais geral. Assim, como o explica Castoriadis, Eu, compreendido como consciência e vontade e não o eu perceptível através dos dados mais ou menos imediatos da fruição consciente ou da alienação laboriosa, devo tomar o lugar das forças obscuras que me dominam e agem por $\operatorname{mim}^{139}$. A afirmação não quer significar a supressão das pulsões muito menos a assimilação do inconsciente. Trata-se sim de tomar seu lugar enquanto "instância de decisão" - o sujeito operando ao nivel da consciência suas decisōes, trabalhando seus fantasmas, suas significações,..., colocando-se enfim numa posição de escolha verdadeira. É a chamada perlaboração psicanalitica. Essas diferenças são sutis, porém de fundamental importância.

Apresentadas as coisas dessa maneira, porém, a passagem, por um homem, da condição que deve ser nomeada como alienação para o "reino da liberdade" - parafraseando Hegel no sentido do espírito absoluto senhor dessa transmutação, e Marx no sentido da transformação das condiçōes materiais de existência enquanto motor da História - no decorrer de um esforço enorme de compreensão e ultrapassagem de seus condicionantes cristalizados na forma de condutas tipificadas e às vezes sintomas psicosomatizados, tudo isso se assemelharia a uma operação técnica realizada em condições de absoluta assepsia. Acontece que há uma dimensão existencial/ética fortemente presente nesse movimento do sujeito em direção a si mesmo, pois se trata de atingir um lugar que, habitando-o, lhe é estranho, um lugar em que ele ainda não é - a subjetividade absoluta, que

\footnotetext{
136 Jaeger W., op.cit., comentando as 'Leis', p. 1359 - grifo nosso.

${ }^{137} \mathrm{RJ}$, Imago, vol XXII, p. 45

138 in Metapsychologie p. 108.

${ }^{139}$ Castoriadis, C. - op. cit., P. 139.
} 
em outra perspectiva não seria nada além do que a objetividade absoluta. Mas essa é uma tarefa civilizatória sustenta aquele Freud amargurado com os rumos da civilizaçăo ocidental, pois, e novamente nos vemos frente ao mesmo tema, ela implica um dever no sentido moral do termo.

Lacan enfatiza esse aspecto bastante adequadamente quando, alterando aquela formulação original propōe que: "O lugar onde estava, pode-se dizer, onde simplesmente costumava estar, é meu dever que eu venha a ocupá-lo" (Là où c'était, peut on dire, là où s'était, c'est mon devoir que je vienne à être) ${ }^{140}$. $\mathrm{O}$ incomensurável desse processo, sua dificuldade intrínseca, a obsessão na qual podemos cair para não realizá-lo encontra-se nos versos de Pessoa,

"Aproveitar o tempo! /Mas o que é o tempo, que eu o aproveite?/Aproveitar o tempo!/Nenhum dia sem linhas.../O trabalho honesto e superior.../O trabalho à Virgílio, à Milton.../Mas é tão difícil ser honesto ou superior!/É tão pouco provável ser Milton ou Virgílio!

Aproveitar o tempo!/Tirar da alma os bocados precisos - nem mais nem menos -/ Para com eles juntar os cubos ajustados/Que fazem gravuras certas na história/(E estão certas também do lado de baixo que não se vê).../Pôr as sensações em castelos de cartas, pobre China dos serões, IE os pensamentos em dominó, igual contra igual./E a vontade em carambola difícil...

...Verbalismo.../Sim, verbalismo.../Aproveitar o tempo!/Não ter um minuto que o exame de consciência desconheça...Não Ter um ato indefinido nem factício.../Não Ter um movimento desconforme com propósitos.../Boas maneiras da alma.../Elegância de persistir..."

(Pessoa, F., Obra Poética, Ficções do Interlúdio/Poesias de Álvaro de Campos - Apostila [458])

Num outro momento do desenvolvimento de sua teoria, Freud descreve com maior acuidade esse processo quando fala do modo pelo qual

${ }^{140}$ Lacan, J. "La Chose Freudienne”, Écrits, Ed. Seuil, Paris, 1966, p. 417. 
o ego desempenha a sua tarefa de autopreservação, o que se mostra ao mesmo tempo como uma atitude sociabilizante:

No que se refere aos eventos intemos, em relação com o ld, ele (o ego) [mesmo, reconhecidamente, não sendo senhor em sua própria casa] desempenha essa tarefa adquirindo controle sobre as exigências dos instintos, decidindo se lhes deve ser consentida satisfação, protelando essa satisfação para momentos e circunstâncias favoráveis no mundo exterior ou suprimindo inteiramente as suas excitações. ${ }^{141}$

No contexto da dimensão subjetiva individual, portanto, a alienação, do que se depreende do pensamento freudiano, mostrar-se-ia como um processo no qual o inconsciente exerce uma função dominadora sobre o consciente e da qual não há conhecimento explicito pelo sujeito, o que indica uma excentricidade radical - como o diz $\operatorname{Lacan}^{142}$ - do Eu em relação a si mesmo, que em seu próprio núcleo abrigaria uma série inumerável de identificações estereotipadas, alienantes, que tem alguns de seus aspectos descritos em versos de Pessoa:

(....) Fiz de mim o que não soube,/E o que podia fazer de mim não o fiz./O dominó que vesti era errado./Conheceram-me logo por quem não era e não desmenti, e perdi-me/Quando quis tirar a máscara,/Estava pegada à cara./Quando a tirei e me vi ao espelho,/Já tinha envelhecido./Estava bêbado, já não sabia vestir o dominó que não tinha tirado./Deitei fora a máscara e dormi no vestiário/Como um cão tolerado pela gerência/Por ser inofensivo (....)

(Pessoa, F., Obra Poética, Ficções do Interlúdio/Poesias de Álvaro de Campos - Tabacaria [456])

Mas, qual o sentido maior da dimensão inconsciente? $E$ qual o significado profundo da dominação do consciente pelo inconsciente, do ponto de vista individual - e seus importantes desdobramentos coletivos? A que se deve esta heteronomia radical ou, dito de outro modo: "Quem é esse

\footnotetext{
141 In Esboço de Psicanálise, RJ, Imago, Vol. XXIII, 1969, p. 156. (a observação entre colchetes é minha.

${ }_{142}$ Lacan, J. "L'instance de la Lettre dans l'inconscient", Ecrits, Paris, Seuil, 1966, p. 524.
} 
outro a quem me encontro mais ligado do que a mim mesmo, pois no seio mais assentido de minha identidade para mim mesmo, é ele que age em meu lugar (em francês: "c'est lui qui m'agit')". ${ }^{143}$

Continuando no interior desse contexto teórico é interessante notar o modo como Lacan, referindo-se ao mesmo assunto, aborda o caráter determinante da ordem simbólica (a sobre-determinação freudiana) no homem, a qual encontra seus rudimentos, suas bases, na distinção entre significante/significado e na primordialidade daquele sobre este - cabendo ao processo psicanalítico "impor ao pensamento essa primordialidade demonstrando que o significante dispensa qualquer 'cogitatio', para exercer reagrupamentos indubitáveis nas significações que subjugam o sujeito." 144 Trata-se em verdade de uma "heteronomia do simbólico", de uma "exterioridade do simbólico em relação ao homem" de tal intensidade que para Lacan ela corresponde à própria noção de inconsciente.

Cabe aqui uma explicação mais atentiva no que concerne à maneira pela qual se desenvolve a atividade psíquica do sujeito e é em Freud que vamos encontrá-la:

Nossa atividade psiquica - escreve ele - pode seguir dois percursos de direções opostas, seja advindo das pulsões pelo sistema inconsciente para atingir o nivel de trabalho do pensamento consciente, seja em função de uma incitação do exterior, passando pelo sistema consciente e pré-consciente para chegar ao nivel dos investimentos inconscientes do Eu e dos objetos. ${ }^{145}$

Mesmo sendo interpretado como "um conceito limite entre o psíquico e o somático", na formulação anterior Freud enfatiza o caráter particular e específico das pulsões, as quais congregariam e empregariam as forças internas localizadas no soma. Estas tratam de investir o aparelho psiquico

\footnotetext{
${ }^{143}$ Lacan, J. op. cit., p. 524 .

144 'Situation de la Psychanalyse en 56', Ecrits, p. 467.

${ }^{145}$ Freud, S. Metapsycologie, Gallimard, Paris, p. 122 (O Inconsciente).
} 
de uma dada pressão, visando com isso à supressão do estado de tensão originário (na fonte emissora) - e isto através de um determinado objeto.

Dessa forma, para fins deste estudo, impōe-se identificar, ainda que arbitrária e artificialmente, ${ }^{146}$ a análise das incitações que chegam ao inconsciente por via externa. Estas incitações de origem externa ao sujeito, que vive num dado sistema sócio-cultural, num dado momento histórico, tomam a forma da linguagem discursiva (própria a este dado sistema), que se personifica e cujos significados se particularizam na voz daquelas pessoas que compõem seu ambiente próximo.

No decorrer do desenvolvimento do sujeito, prevalecerá, portanto, como base das incitações externas, um discurso, o discurso do outro, que não ele mesmo (que está a sofrer o processo da aculturação) o qual atuará como fonte privilegiada para o acesso do sujeito ao mundo e a si próprio.

Cumpre ressaltar, no entanto, que mesmo sendo importante e exercendo quase sempre um papel determinante e alienante, o discurso de Outrem enseja também a construção do meu próprio discurso. Assim, para expressar numa linguagem existencialista/sartriana, ao lado de um Serpara-Outrem forma-se um Ser-para-Si, o qual poderia ser comparado ao que se chama de senso íntimo e que dá lugar ao autoconhecimento e ao autojulgamento.

Ele (o discurso de outrem) se constitui em realidade, no suporte e na condição eficiente da atividade do sujeito. Este suporte e este conteúdo não são, nem simplesmente do sujeito, nem simplesmente do outrem (ou do

\footnotetext{
${ }^{146}$ Digo arbitrária e artificialmente, pois em realidade não há sentido em promover a separação estanque entre interioridade e exterioridade, dado que o sujeito da percepção existe num movimento constante de "troca" com o mundo objetivo - o qual se constitui, inclusive, na base da formação primária do que chamamos Eu.
} 
mundo). Ele é a união produzida e produtora do Eu e dos Outros (ou do mundo) ${ }^{147}$.

Por razões variadas, no entanto, que não cabe aqui discutir - de origem primordialmente afetiva, será esse discurso de outrem que atuará como base na incitação de origem externa, que vai impressionar o sistema inconsciente - o qual por sua vez acabará por identificar-se total ou parcialmente a esse discurso: o inconsciente torna-se um "Outro" que não eu mesmo, mas trata-se do Outro em mim. $O$ inconsciente na linguagem lacaniana ${ }^{148}$ é o discurso do outro, o que quer dizer que ele se identifica à rede de significações - desejos, objetivos, investimentos, exigências, expectativas, à qual o sujeito é submetido desde sua concepção (e mesmo antes) por parte daqueles que o engendraram e o criaram/educaram. "Um pólo de atributos, eis o que é o sujeito antes de seu nascimento. De atributos, isto quer dizer de significantes mais ou menos ligados em um discurso" 49 .

Chegamos neste ponto, justamente na área de intersecção entre individuo/sociedade/história, pois que a alienação passa a tomar o caráter de um processo que é, ao mesmo tempo, intra e intersubjetivo e que tem necessariamente raízes num dado contexto histórico/social: a alienação se realiza no discurso de outrem (portanto exterior) que existe em mim (interiorizado) e me domina (fala por mim) exteriorizando-se de maneiras diferenciadas (dado o caráter de reprodução estar vinculado necessariamente a uma interpretação que implica por sua vez a reelaboração, no sentido de sua radicalização afirmativa ou transformação, em algum grau do discurso inicial). De tal maneira que o que tenho como certo como sendo o meu querer tem certamente como base o querer de outro, outrem. Esses quereres encontram-se ordenados em um

\footnotetext{
${ }_{148}^{147}$ In Castoriadis, C. - op. cit., p. 144.

${ }^{148}$ Lacan, J. - op. cit.

${ }^{149}$ Lacan, J. ibid., pp. $651-653$.
} 
"encadeamento parecido com a procissão dos cegos de Breughel, onde cada qual sem dúvida, mantém sua mão na mão daquele que o precede, mas ninguém sabe para onde todos se dirigem. ${ }^{m 50}$

Desta maneira, na medida em que lançamos mão da teoria psicanalítica (além da própria experiência clínica no exercício da técnica psicanalitica) podemos entrar em contato com o conflito interior que habita cada individuo desde seu nascimento e que se constitui na oposição/complementaridade entre o Eu e outrem (interiorizado) num processo de influência reciproca. A priori intangível para o sujeito mediano que somos nós, vivemos esse processo como um certo desconforto, talvez uma pequena angústia que desponta aqui e ali, sem nome que propiciasse uma referência explícita, querida.

Sob outra perspectiva, podemos interpretar este conflito como o desenrolar dialético de uma luta entre a lei de outrem, que atua em meu interior - significando minha alienação/heteronomia (hetero = outro; nomos = lei) em relação a ela, e a minha própria lei - significando aqui minha liberdade ou autonomia (auto $=$ si mesmo) em face dessa lei de outrem ${ }^{151}$ ou, dito de outro modo, minha fidelidade à minha própria lei.

O limite da alienação/heteronomia no individuo seria alcançado quando ele não consegue mais distinguir entre seu Ser-para-si e seu Ser-para-outrem. Esta é a contrapartida de uma situação onde passo a dar maior importância ao objeto que sou para outrem em detrimento ao sujeito que sou para mim.

Vale dizer que o indivíduo não se constitui, de início ao menos, em objeto para si próprio, ao passo que para o outro ele é, desde sempre, um

\footnotetext{
${ }^{150}$ Lacan, J. "Kant avec Sade", Écrits, Ed. Seuil, Paris, p. 784-5.

${ }^{151}$ Interessante lembrar aqui que na concepção de Kant, a heteronomia significa aquele estado da vontade que busca fora dela mesma - nas impulsões ou nas regras sociais, o principio de sua ação.
} 
objeto. Ainda que um objeto de caráter especial e nunca de forma absoluta, o que seria, nas palavras de Merleau-Ponty, um julgamento insincero.

Assim, na dimensão subjetiva, a alienação/heteronomia do individuo realiza-se concretamente na medida em que ele se aliena ao objeto no qual se constitui aos olhos de outrem. "Deixando-se" governar por um outro, o que quer dizer por algo que só tem realidade aos olhos dos outros, o indivíduo aliena-se de seu Ser-para-si em favor de seu Ser-para-outrem. Partindo de um princípio de inversão do real ele pode julgar, sem ter claramente consciência, que a aparência (aquilo que ele é para os outros) é a realidade e que a realidade (aquilo que ele é para si) não é senão aparência - processo que, mais freqüentemente, incorpora a ambigüidade das duas posições que se mesclam num cotidiano exuberante ou amorfo, não importa, pois se tratam de distinções apenas superficiais.

Deve ficar claro assim, que a caracteristica essencial do discurso de outrem, é a sua relação com a função imaginária. O essencial da heteronomia/alienação nessas condições, ao nivel individual, é a dominação por um imaginário autonomizado que se arrogou à função de definir para o sujeito sua realidade e seu querer. Imaginário este que, uma vez "recebido" o discurso do Outro, trata de transforma-lo à sua revelia, procedendo a uma leitura que tende a "repeti-10", mas também que tende a transformá-lo, amplificando-o.

Se queremos valorizar as implicações político-sociais mais visiveis das atitudes individuais, podemos nos situar em outra perspectiva teórica, o existencialismo sartriano, onde esse tipo de alienação/heteronomia é percebido como bastante comum, tratando-se muitas vezes, no entanto, de um processo temporário e parcial. O problema é quando um indivíduo é, desde cedo, submetido a uma pressão social considerável, fazendo com que seu Ser-para-outrem seja objeto de uma representação coletiva acompanhada de julgamentos de valor e de interdições sociais. Pode 
acontecer, então, que a alienação torne-se definitiva. Esses indivíduos passam por um processo de interiorização dos julgamentos objetivos que a coletividade porta sobre eles, passando a pensar-se a si mesmos, na sua singularidade subjetiva, a partir de um "caráter étnico", de uma "natureza" ou de uma "essência", que não fazem senão expressar o desprezo no qual a coletividade os tem ${ }^{152}$. Estendendo esse raciocinio, podemos dizer talvez que em nossa sociedade certos estratos da população são submetidos a um processo semelhante de tal modo que, antes de serem indivíduos livres, as pessoas constituem-se em objeto de uma representação coletiva mais ou menos asfixiante que termina por "moldá-las" a determinadas expectativas de ordem existencial, encontrando suporte nos elementos raciais e religiosos ou políticos, sociais, econômicos, etc.

Entende-se desse modo, que a encarnação pelos indivíduos dos papéis sociais para eles "preparados" não se dá de forma mecânica e linear, tendo mesmo um caráter ambíguo, pois que eles são persuadidos e se deixam persuadir - por força primordialmente do conjunto/qualidade dos afetos envolvidos sejam eles, sobretudo, positivos ou negativos - que a definição objetiva a que são submetidos aplica-se em realidade a seu Ser subjetivo mais profundo.

No interior do campo psicanalítico, Fromm E., ao lidar com a problemática da liberdade no homem ${ }^{153}$ aborda a questão da alienação do sujeito no outro (interior ou exterior). A análise parte do conflito que habita $o$ individuo que se encontra diante da possibilidade de liberdade, a qual é colocada como fruto de um "processo de individuação", que acontece nos niveis biológico/emocional/moral - no qual o homem, uma vez rompidos seus "vinculos primários", descobre-se a si e aos outros como individuos, como entidades separadas.

\footnotetext{
${ }^{152}$ Sartre, J. P. in Saint Genet Comedien et Martyr, Gallimard, Paris, pp. 40- 5.

${ }^{153}$ Fromm, E. - O Medo à Liberdade, RJ, Zahar, 1978, p. 114 e seguintes.
} 
Este movimento, na interpretação de Fromm, provoca um sentimento conflituoso no sujeito, que o leva a cindir-se entre a experiência do aumento (potencial) do vigor do seu Eu e a realidade crescente de sua solidão/isolamento intrínsecos, que the acarreta ansiedade e angústia agravadas por um sentimento difuso de pequenez e impotência, diante da "brecha" que ele sente se abrir entre si próprio e o mundo ${ }^{154}$.

Neste contexto, Fromm passa a descrever e analisar, como, no esforço para escapar da solidão e da impotência, os individuos por vezes dispõem-se mesmo a descartar-se de seu próprio Eu para submeter-se a outrem - que pode encarnar-se em alguma forma de autoridade ou no "conformismo" compulsivo aos padrōes de comportamento social vigentes.

Essa situação encontra seu complemento justamente em seu "inverso" - a tendência à dominação por outrem - que no fundo quer exprimir, tanto quanto na tendência à submissão, um único processo (mais geral) que se perfaz na tendência à renúncia da liberdade (entendida aqui como a questão que se coloca para o sujeito quando de sua separação - de fato dos vínculos primários que o tornavam "cúmplice" do mundo). Em sua concepção genérica, portanto, este é um processo, aos olhos de Fromm, que identifica a alienação a uma tendência de fuga (da liberdade) que se exprime numa renúncia do sujeito à independência do próprio ego individual na tentativa de fundi-lo com alguém ou algo no mundo exterior (como é caracteristico e natural na fase fetal), implicando, portanto, no estabelecimento de relações de tipo simbiótico (com as pessoas e coisas) através da submissão (masoquismo) elou da dominação (sadismo).

No que concerne a discussão sobre o processo de individuação tão importante para o perfeito entendimento das causas primeiras do processo de alienação, podemos estabelecer uma relação estreita entre o discurso de

${ }^{154}$ Fromm, E. - id., ibid., p. 114 e seguintes. 
Fromm e as concepções freudianas do "Eu hedônico" e do "princípio de realidade", que intervêm no estado de egocentrismo primitivo do sujeito ${ }^{155}$.

De fato, a descoberta de si próprio e dos outro como entidades (abstratas) separadas - e o sentimento de insegurança e angústia daí decorrentes - advém, segundo Freud, da percepção pelo Eu individual dos objetos exteriores a si próprio. E esta percepção se dá por meio de experiências tais que o "principio do prazer", enquanto senhor absoluto do desenvolvimento do indivíduo, exigiria que fossem suprimidas ou evitadas. Prazer esse significativa e deliciosamente exposto por Pessoa:

"Ai que prazer/Não cumprir um dever,/Ter um livro para ler/E não o fazer!/Ler é maçada./Estudar é nada/O sol doira/Sem literatura.

O rio corre, bem ou mal,/Sem edição original./E a brisa, essa,/De tão naturalmente matinal,/Como tem tempo, não tem pressa...

Livros são papéis pintados com tinta./Estudar é uma coisa em que está indistinta/A distinção entre nada e coisa nenhuma.

(....) Grande é a poesia, a bondade e as danças...Mas o melhor do mundo são as crianças,fFlores, música, o luar, e o sol, que peca/Só quando, em vez de criar, seca.

Mas o mais do que isto/É Jesus Cristo./Que não sabia nada de finanças/Nem consta que tivesse biblioteca...."

(Pessoa, F., Obra Poética, Poesia de Fernando Pessoa/Cancioneiro [195)

Tem lugar então, uma tendência à formação de um Eu puramente hedônico - ao qual se oporia um mundo exterior estranho e ameaçador - o qual em seguida sofrerá necessariamente retificaçōes impostas pela experiência. A partir deste momento, forçado a distinguir entre os inputs de origem interna - que se relacionam ao $\mathrm{Eu}$ - e os inputs de origem externa cuja fonte é o mundo exterior - o indivíduo passa a assimilar o chamado "princípio da realidade" que deverá dominar sua evolução ulterior.

\footnotetext{
${ }^{155}$ Freud, S. in Além do Principio do Prazer, Le Moi et le ça; Malaise dans le Civilisation.
} 
À origem, portanto, o Eu inclui tudo (a ligação simbiótica), mais tarde ele exclui de si o mundo exterior. Em conseqüência, nosso sentimento atual do Eu não é senão o resíduo limitado de um sentimento de extensão maior..., e que correspondia a uma união mais intima do Eu com seu ambiente. ${ }^{156}$

No entanto, deve-se observar que em muitos individuos o sentimento primário do Eu conserva-se mesmo na idade madura, acarretando então representações atuais (ou representações passadas re-atualizadas) cujo conteúdo é carregado das mesmas noçōes/sentimentos de ilimitabilidade, não diferenciação e união com o "todo".

De maneira distinta vemos que num outro domínio - a filosofia - a mesma questão revestida de outras formas vem sendo colocada desde a Grécia antiga. Na transição de filosofia clássica, por exemplo, com o idealismo, encontramos a elaboração por Hegel da noção de dialética no interior da análise da "relação senhor-escravo", onde o que ressalta é seu caráter ambíguo. ${ }^{157}$

Esta ambigüidade advém do fato que, se em aparência existe um fluxo de dependência/alienação que tem um sentido único - do escravo em relação ao senhor - uma análise mais aprofundada do problema leva Hegel a discernir um processo bem mais complexo, que tende necessariamente à complementaridade biunívoca dos dois elementos da relação.

Assim, da mesma forma que existe dependência e necessidade vital, e, portanto, alienação do escravo em relação ao senhor, podemos identificar, complementarmente, dependência e necessidade vital do senhor em relação ao escravo (o senhor sendo escravo do escravo). Essa não é somente uma

\footnotetext{
${ }^{156}$ Freud, S. - 'Malaise dans la Civilisation' - PUF, Paris, 1979, p. 10 (trad. Jean Hyppolite).

${ }^{157}$ In Hegel, G. W. F. La Phenomenologie de l'Esprit, trad. Jean Hyppolite, Paris, Aubier, 1941.
} 
determinação lógica formal. É, ao mesmo tempo ontológica e interiormente, na sua posição "objetiva" e "subjetiva", que o senhor é escravo do escravo (e vice-versa). "O senhor é ..., como mediação ou como um Ser-para-si, que é para si somente por intermédio de um Outro..." ${ }^{158}$

Mas a ambigüidade/conflito da relação só se perfaz quando levamos em conta que, "da mesma forma que a dominação mostra que sua essência é o inverso daquilo que ela quer ser, a servidão se tomará, no decorrer de sua concretização, o contrário daquilo que ela é no imediato"159. Assim, "o senhor se tornará o escravo do escravo e o escravo se tornará o senhor do senhor ${ }^{1160}$, num movimento de alienação recíproca: por um lado, o "Ser" do escravo se perfaz no Outro (o senhor) - sendo, porém, concretamente escravo - na mesma medida em que o "Ser" do senhor se perfaz no Outro (o escravo) - sendo que ele também, concretamente, existe como senhor.

Observamos assim, a tendência ao estabelecimento de relações que poderiamos chamar de simbióticas - vividas de forma consciente ou inconsciente pelos indivíduos - que Hegel indica como sendo imanente mesmo à tipologia das relações de dominação/servidão. O termo simbiose (do grego sumbiôsis/ sumbioum - viver (bioum) junto/com (sum)) assume aqui um significado quase biológico de associação durável e reciprocamente proveitosa entre dois organismos. $E$ é neste mesmo sentido que podemos traçar o elo de conexão entre a interpretação hegeliana e a elaboração psicanalítica.

Mas o que temos pela frente quando há um esforço do indivíduo, favorecido ou não pela comunidade onde está inserido, no sentido de escapar desse aplastramento?

\footnotetext{
${ }_{158}^{158} \mathrm{Hegel,} \mathrm{G.W.F.} \mathrm{op.} \mathrm{cit.,} \mathrm{p.} 161$.

159 Id., ibid., p. 163.

${ }^{100}$ Nota de J. Hyppolite à p. 163.
} 
Viver no mundo, enfim, ganhar a vida ou nem isso e estar submetido a todos os impactos dramas e tensōes que isso implica nos esconde, freqüentemente, que nos distanciamos de nós mesmos e adentramos um mundo artificial no qual nem "nosso" tempo, nem "nossos" pensamentos, nem "nosso" comportamento, ao final das contas, nos pertencem. Havendo marcada tendência a nos conformar ao que nos pedem para ser (mas quem, afinal?, esse impessoal coletivo?), torna-se difícil permanecermos senhores de nossas próprias almas como afirma Shah ${ }^{161}$.

Legatários da verdade, quer dizer fieis à essência da filosofia da educação platônica e contrários à retórica hoje encarnada pelo mercado, seja enquanto educadores ou educandos para a saúde, a tarefa que nos cabe, reportando-nos mais uma vez à citação do Prof. Lefevre e amplificando-a, não é verdadeiramente pequena.

\section{A dimensão social - coletiva do conflito alienação/heteronomia, liberdade/autonomia}

Trata-se aqui de discernir o espaço sócio-histórico no qual tem lugar necessariamente a ação de cada homem em sua luta pela autonomia, mantendo em perspectiva os desenvolvimentos anteriores.

Temos a considerar como ponto de partida, que o social/histórico não pode ser conformado à mera adição indefinida das redes intra e intersubjetivas, não sendo tampouco seu simples produto. $O$ social/histórico nesta perspectiva

(....) é o coletivo anônimo, o humano impessoal que preenche toda formação social dada, englobando-a também, que coloca cada sociedade entre as outras $e$ as inscreve todas numa continuidade onde, de certo modo, estão presentes aqueles que não mais existem,

${ }^{161}$ O.A. Shah - Un apprentissage du soufisme, Guy Trédaniel Éditeur, Paris, 2001, p. 
aqueles que estão fora, e mesmo aqueles que estão por nascer. $\dot{E}$ de um lado constituido pelas estruturas dadas, instituições e obras "materializadas" (....), e de outro lado ele (o social/histórico) é o que estrutura, institui, materializa. ${ }^{162}$

Nessa perspectiva, a alienação encontra suas condições de existência e reprodução, para além do inconsciente individual e da relação intersubjetiva que acontece nesta dimensão, no próprio mundo do social /histórico.

Com efeito, a práxis individual - entendida como a prática que visa os outros como seres autônomos /livres - encontra como limite, para além do "discurso do Outro" (interiorizado), a própria estrutura social/ histórica que tem um caráter alienante (supondo, legitimamente, certas condições de privação e opressão, de solidificação e enrijecimento da estrutura global, material e institucional, de indução, mistificação, manipulação e violência).

O outro, na dimensão social /histórica, "encarna-se" fora do inconsciente individual. Ele tende a desaparecer no anonimato coletivo, na impessoalidade dos "mecanismos econômicos do mercado" e da lei de alguns (que é apresentada como a lei de todos).

No interior dessa "lógica", transparece a ambigüidade do conflito entre Alienação e Liberdade, pois, na mesma medida em que a presença do Outro (que passa a encarnar-se fora da dimensão individual-subjetiva) "por delegação" no inconsciente de massas de indivíduos dominados é condição necessária desta encarnação, o inverso é igualmente verdadeiro, pois a detenção do poder (a força) por alguns é sem dúvida condição de alienação perpetuada. ${ }^{163}$

\footnotetext{
102 In Castoriadis, C. - op. cit., p. 148.

163 In Castoriadis, C. - op. cit., p. 150.
} 
Nesse contexto, não tem sentido o estudo simplesmente psicológico da alienação - que procure encontrar exclusivamente na estrutura dos individuos, no seu masoquismo, etc., as condições da alienação. Isto porque, sendo essencial lembrar que a alienação/heteronomia deve sempre encontrar (também) suas condições de reprodução em cada indivíduo dominado, ela deve também encontrar tais condições na própria estrutura social ${ }^{164}$, que torna as chances dos individuos de saber (no sentido de ter conhecimento/informação sobre o que trata "verdadeiramente" a realidade) e de querer (no sentido de propiciar-Ihes as condiçōes concretas para vislumbrar, para além do discurso do Outro, seu próprio querer), na prática, negligenciáveis.

Assume um lugar de importante em nossa análise, portanto, a interpretação do campo social tal como os indivíduos o experienciam em sua prática quotidiana, ou seja, como um "espaço" sócio-cultural, políticoeconômico dividido em classes - cuja participação ativa ou reativa na totalidade desse "espaço" vincula-se, genericamente, (e com uma intensidade extremamente variável), à sua posição hierárquica original no conjunto das classes (o que é determinado, sobretudo pela chamada "situação de nascimento"). ${ }^{165}$

Por acreditarmos ser este ponto já suficientemente desenvolvido no campo teórico social e político, não nos ateremos a ele mais do que já o fizemos. Isto não significa atribuir um valor menor à análise da sociedade de classes brasileira, mesmo porque ela compõe a base sobre a qual

\footnotetext{
${ }^{164}$ A base da estrutura social, no entanto é constituida por suas instituiçōes, o que nos permite deduzir que a alienaçäo tende a ser produzida e reproduzida no nivel social global por elas (a "alienação instituída" como diz Castoriadis). Porém, além de seu peso real especifico, existe também sua mistificação, pois, uma vez criada a instituição, esta parece se autonomizar, através de uma inércia e uma lógica próprias frente ao homem.

165 "Não se pode falar em nenhum caso, de escolha,... é suficiente que eu tenha nascido e que eu exista para perceber minha vida como dificil e constrangedora, e essa não é uma escolha minha". In Merleau-Ponty, M. - op. cit., p. 507.
} 
estrutura-se e desenvolve-se a personalidade individual no seio de cada classe, dentro da totalidade social. ${ }^{166}$

Seria mesmo de todo desprovido de significação abordar o indivíduo sem levar em conta seu aspecto universal. De fato a generalidade e a individualidade do sujeito, a subjetividade qualificada e a subjetividade pura, o anonimato do impessoal coletivo e o anonimato da consciência não são duas concepções do sujeito, entre os quais seria preciso escolher. Ao contrário, como o propõe M. Ponty, estes "são dois momentos de uma estrutura única que é o sujeito concreto". ${ }^{167}$

Chegamos outra vez à realidade histórica e política desses conceitos, pois eles podem ser estendidos a comunidades de homens, na forma de nações ou de civilizações mesmo, que se encontram impregnados das ideologias, e aqui cabe esse conceito, prevalecentes nessas comunidades. Essas ideologias podem ser muito antigas e, por isso, encontram-se tão profundamente enraizadas, e de maneira tão sutil, que não podem mais ser identificadas como tais pelas pessoas, que tenderão "naturalmente" a perpetuá-las.

A "alguma coisa" de que falava Aristóteles, que tem o poder de avassalar o homem para além de sua vontade própria, portanto, parece apontar para a condição de alienação até aqui descrita. Torna-se necessário, porém, amplificando a reflexão, verificar os limites que se impõe à extrapolação desses argumentos analisando a situação da liberdade/autonomia também possiveis de serem alcançadas por um

\footnotetext{
${ }^{106} \mathrm{O}$ assunto foi tratado extensamente particularmente nos meus trabalhos sobre "O Capital Multinacional no Brasil" (Mémoire de Maîtrise); "Estrutura Social e Processos de Mobilização Popular no Brasil" (Mémoire de D.E. A.); "Mecanismos de Produção, Reprodução e Negação das Relações de Dominação Socioeconômicas" (Projeto Thèse de Doctorat de Troisième Cycle).
}

${ }^{167}$ Id. ibid, p. 514. 
individuo - já que a proposição do paradigma existencial implicaria a este ponto cada um dos adolescentes/educandos visados durante uma intervenção. Ao efetuar essa análise, tentaremos, ao mesmo tempo, estabelecer as possibilidades e limites subjetivos do êxito de uma intervenção no interior de um programa de promoção da saúde junto a adolescentes.

\section{A situação da liberdade/autonomia}

O que se opõe à situação de alienação/heteronomia em cada indivíduo, presume-se, deva ser um movimento de emancipação em direção a uma situação de liberdade/autonomia. Um projeto, etimologicamente um pró-jecto, uma meta a alcançar que o lança adiante do ponto em que se encontra - o que implica dizer que, antes de tudo, o indivíduo reconhece minimamente esse ponto, tem ciência como que de sua topografia, seu relevo, suas coordenadas aproximadas, e por isso têm consciência de sua perda de tempo, de seus desatinos até conseguir aceitar a existência e mesmo a superioridade "adequada", digamos, de um outro lugar a chegar. Depois disso, ele tem pela frente o caminho que o leva para esse outro lugar, mas nesse caso trata-se de um caminho que lhe aparece composto de descriçōes esparsas, sendo a realidade desse outro ponto a alcançar muito dependente de algo como a aceitação de uma intuição que o visa, mas não pode vê-lo claramente. Quase uma aposta que precisa ser feita, bastante parecida ao convite que, no interior de um programa de promoção da saúde, fazemos a um adolescente em situação de vulnerabilidade social.

\section{A LENDA DAS AREIAS}

"Vindo desde as suas origens nas distantes montanhas e após passar por inúmeros acidentes nas regiôes campestres, um rio finalmente alcançou as areias do deserto. $E$ do mesmo modo como vencera as outras barreiras o rio tentou atravessar esta agora, mas se deu conta de que mal suas águas tocavam na areia nela 
desapareciam. Estava convicto, no entanto, de que fazia parte de seu destino cruzar aquele deserto, embora não conseguisse fazê-lo. Então uma voz misteriosa, saída do próprio deserto arenoso, sussurrou:

- O vento cruza o deserto, o mesmo pode fazer o rio.

O rio contestou que ele estava se arremessando contra as areias, sendo assim absorvido enquanto o vento podia voar, conseguindo dessa maneira atravessar o deserto.

- Jogando-se com violência como vem fazendo não conseguirá cruzá-lo.

Assim você desaparecerá ou se transformará num pântano. Deve permitir que o vento o conduza a seu destino.

- Mas como isso pode acontecer?

- Consentindo em ser absorvido pelo vento.

Tal sugestão não era aceitável para o rio. Afinal de contas, ele nunca fora absorvido até então. Não desejava perder a sua individualidade. Uma vez a tendo perdido, como poderia saber se a recuperaria mais tarde?

- O vento desempenha essa função- disseram as areias. -Eleva a água, a conduz sobre o deserto e depois a deixa cair. Caindo na forma de chuva, a água novamente se converte num rio.

- Como posso saber se isso é verdade?

- Pois assim é, e se não acredita não se tornará outra coisa senão um pântano, e ainda isto levaria muitos e muitos anos . E um pântano não é certamente a mesma coisa que um rio.

- Mas não posso continuar sendo o mesmo rio que sou agora?

- Você não pode, em caso algum, permanecer assim - retrucou a voz. - Sua parte essencial é transportada e forma um rio novamente. Você é chamado assim ainda hoje por não saber qual é a sua parte essencial.

Ao ouvir tais palavras, certos ecos começaram a ressoar nos pensamentos mais profundos do rio. Recordou vagamente um estágio em que ele, ou uma parte dele, não sabia qual, fora transportada nos braços do vento. Também se lembrou, ou the pareceu assim, de que era isso o que devia fazer, conquanto não fosse a coisa mais natural.

Então, o rio elevou seus vapores nos acolhedores braços do vento, que suave e facilmente o conduziu para o alto e para bem longe, deixando-o cair suavemente tão logo tinham alcançado o topo da montanha, milhas e milhas mais longe. E porque tivera suas dúvidas o rio pôde recordar e gravar com mais firmeza em sua mente os detalhes daquela sua experiência. E ponderou:

- Sim, agora conheço a minha verdadeira identidade.

O rio estava fazendo o seu aprendizado, mas as areias sussurraram:

- Nós temos o conhecimento porque vemos essa operação ocorrer dia após dia, e porque nós, as areias, nos estendemos por todo o caminho que vai desde as margens do rio até a montanha. E é 
por isso que se diz que o caminho pelo qual o Rio da Vida tem de seguir em sua travessia está escrito nas Areias."

(I. Shah, Contes Denviches, Le Courrier du Livre, Paris, 1979, p.20)

\section{A questão da liberdade ${ }^{168}$ ou Do Significado Profundo da Educação para a Saúde}

\section{Possibilidades e limites subjetivos do êxito de uma intervenção}

De que forma poderia ser tratada a questão da liberdade? De um lado ela pode ser alçada à condição de absoluto, sem qualquer determinação exterior. Não haveria nesta perspectiva nada que pudesse limitá-la verdadeiramente, a não ser aquilo que a própria liberdade tivesse determinado como limite para suas iniciativas, e o sujeito não teria senão a exterioridade que ele próprio se daria. Visto que é o sujeito ele mesmo que, em sua existência, faz aparecer o sentido e o valor das coisas e como nenhuma coisa pode atingi-lo senão em se fazendo para ele sentido e valor, não haveria ação das coisas sobre o sujeito, não havendo senão uma significação (no sentido ativo) de caráter centrífugo - do sujeito para as coisas (para o mundo).

Essas considerações resumem, ainda que de maneira muito abstrata, a posição de Sartre (de Sartre em L'Être et le Neant), que sustenta que "o homem, estando condenado a ser livre, porta o peso do mundo inteiro sobre seus ombros, ele é responsável do mundo e dele mesmo enquanto maneira de ser"169.

\footnotetext{
${ }^{168}$ As consideraçōes desenvolvidas neste ensaio estāo baseadas principalmente nas idéias propostas por M. Ponty in 'Phenomenologie de La Perception', sendo balizadas também pelas proposições de J.P.Sartre in 'L'Etre et le Neant'.

${ }^{1}$ Sartre, J.P. - L'Etre et le Neant - p. 612.
} 
Mesmo colocando-se diante da total facticidade e da contingência absoluta do mundo - o que se perfaz no ato de nascimento, no lugar ocupado pelo sujeito, no seu passado, no seu meio e na existência de um alter-ego, - Sartre condiciona-as a uma pretensa liberdade sem limites (que seria em última instância a responsável pela existência, para o sujeito, de uma facticidade, (o que quer dizer que da liberdade eu chego à facticidade $e$ não o contrário). ${ }^{170}$

Apoiando-se numa dialética sem mediaçōes - uma dialética do tudo ou nada como o diz Waelhens ${ }^{171}$ - a ontologia sartriana aplica-se na análise das noções de causalidade e motivação - as quais, é preciso lembrar, perderiam até seu sentido de ser, se condicionadas por uma liberdade absoluta. De fato, como nos mostra M. Ponty, se não se puder pensar num meio termo entre a liberdade absoluta e o determinismo, ou bem os motivos seriam vividos como impositivos (o que eles não poderiam ser, devido à hipótese do caráter absoluto da liberdade), ou bem eles não teriam um peso intrinseco, o que quer dizer que eles teriam tão somente o alcance que a vontade do sujeito quisesse lhes acordar.

A inexistência de mediações que relativizassem essas colocações implica, no pensamento sartriano, num posicionamento radical: "ou bem os motivos têm a força de me impulsionar à ação, e então não existe liberdade, ou bem eles não a têm, e então a liberdade é integral, tão grande nas piores torturas quanto na paz de minha casa". ${ }^{172}$

A liberdade não seria uma caracteristica própria ou ainda uma modalidade da ação dita voluntária, mas transcenderia todas as decisões e todas as deliberações. Mesmo a limitação da liberdade por uma determinada situação seria ainda vista como equivocada, uma vez que os limites

\footnotetext{
${ }^{170}$ Id , ibid , p. 607.

${ }_{171}$ De Waelhens, A., Une Phenomenologie de l'Ambiguité, p. 312.

172 Merleau-Ponty, M., p. 497.
} 
desaparecem correlativamente a um projeto sempre livremente estabelecido pelo sujeito. "Não há situação senão em um mundo orientado, mas o mundo não se orienta ou não torna sua orientação qualificada senão pelos projetos do homem ${ }^{\prime 77}$. A liberdade seria sempre absoluta, existente integralmente, ou totalmente inexistente, pois até mesmo na relação senhor-escravo, o escravo seria percebido tão livre quando acorrentado quanto seu senhor (uma vez que ele teria "escolhido" não fugir). Mas, explica Sartre, não se quer assim estabelecer uma liberdade que permanecesse indeterminada: "o escravo acorrentado é livre para romper suas correntes". ${ }^{174}$

Numa tal perspectiva teórica, poderia se insinuar com Lukács ${ }^{175}$ que em verdade não haveria para o homem, nenhuma liberdade ainda a conquistar, o que equivaleria na prática à aceitação pura e simples da opressão e da dominação. Isto porque permaneceria sem solução o problema do alcance real da liberdade do sujeito, pois, tendo como base o exemplo anteriormente citado, ter-se-ia que um escravo que recusasse suas correntes, mas que a elas continuasse preso, seria tão livre quanto um homem realmente livre que se move de acordo com sua "vontade explícita".

Esta posição, do ponto de vista do individuo singular, talvez pudesse ser reavaliada, uma vez que, para si próprio e ao menos explicitamente, o indivíduo quer (e no limite ele tem que!) perceber-se como senhor da própria vontade - isto é, claro, dentro dos limites "socialmente aceitáveis" de alienação (o caso limite da esquizofrenia não sendo aqui considerado); e no interior dos limites mais ou menos estreitos "estipulados" pela autoconsciência explícita do sujeito.

Assim, o escravo acorrentado que "escolhe" não romper suas correntes - dadas, por exemplo, as condiçōes de castigo/punição que se

\footnotetext{
${ }^{173}$ De Waelhens A. - op. cit. p, 313.

174 Sartre, J.P. - op. cit. - p. 608.

${ }^{175}$ Lukács, G.V. - Existencialisme ou Marxisme - p. 106.
} 
seguiriam a uma tentativa frustrada - para poder continuar percebendo-se como sujeito vivo (e tão somente isso) teria que elaborar certos mecanismos compensatórios que the permitissem experimentar a liberdade nos recônditos mais obscuros ou menos acessiveis de sua existência.

Assim, a percepção de si próprio como sujeito estaria direta e necessariamente associada a um determinado nivel de liberdade por ele vivido/experienciado - sendo impossivel, pois se conceber a vida de qualquer pessoa (desde que não seja quase meramente vegetativa como aquela determinada pelo escape total da realidade) sem um mínimo de liberdade, ou dito de outra maneira: na alienação total (raciocínio que nos aproxima do sentido da crítica desenvolvida por Castoriadis, C., in L'Institution Imaginaire de la Societé).

À concepção de uma liberdade fechada sobre si mesma, impōe-se contrapor não sua negação absoluta - o que nos levaria a um outro determinismo - mas uma posição mediana que mostre que:

se a liberdade é igual em todas nossas ações (....) se ela não pode ser comparada à nossa conduta, se o escravo tem o mesmo tanto de liberdade seja vivendo no medo, seja quebrando suas correntes, (então) não se pode dizer que exista qualquer ação livre, a liberdade está aquém de todas as ações $(. . .)^{176}$

Ela se situaria em todos os lugares, mas ao mesmo tempo em lugar nenhum.

Neste ponto é preciso lançar mão da idéia de engajamento que, como atitude do sujeito, só passa a existir quando a liberdade tem que se efetivar dado que ela nāo se encontra de uma vez por todas adquirida. Além disso "a própria noção de liberdade exige que nossa decisão penetre profundamente o futuro, que alguma coisa seja feito por ela....177 - o que nos coloca

${ }^{176}$ M. Ponty, M. - op. cit., p. 499.

177 Id., ibid., 499. 
diretamente em contato com nossa situação frente a nossos educandos para a saúde.

Os raciocínios até aqui desenvolvidos nos mostram que, se de um lado a liberdade existe realmente como possibilidade concreta, de outro lado ela não é nunca absoluta. É preciso, pois conceber uma liberdade mundana que se contraponha a uma "idéia de liberdade" metafísica.

Na procura de uma posição mediana, Merleau-Ponty coloca antes de qualquer coisa, que a idéia de escolha pelos sujeitos de (seu) caráter inteligivel não pode ser aceita. Isto porque não somente não existe tempo que seja anterior ao tempo, mas também porque em primeiro lugar a escolha supōe sempre um engajamento anterior - mas um engajamento sobre o quê? e principalmente talvez, de quem?, de um sujeito pré-mundano ${ }^{178}-\mathrm{e}$ em segundo lugar a idéia mesmo de uma escolha primeira é, em si contraditória.

Nem mesmo na análise de nossas deliberaçōes comuns se poderia esperar encontrar os elementos para a formação de uma teoria de liberdade, pois se considera como consolidada a idéia que "a liberdade não se confunde com as decisões abstratas da vontade, em luta com os motivos ou as paixões"179.

A decisão transcende a ordem da deliberação, e os motivos que a teriam respaldado não podem explicá-la, não sendo suficientes nem mesmo para assegurar sua manutenção. Ao contrário, os motivos tiram seu peso de

\footnotetext{
${ }^{178}$ Tal afirmação, inclusive, na sua significação profunda, nos remeteria não ao sujeito ele mesmo, mas sim as estruturas subjetivas que a ele deram origem, fundamentadas primordialmente na figura da mãe, e do pai (conforme os desenvolvimentos realizados, por Lacan, J. in Ecrits citados anteriormente).

${ }^{179}$ Merleau-Ponty, M. - op. cit., p. 500.
} 
uma decisão já tomada que tem de justificar-se frente ao pensamento explicito ${ }^{180}$.

Não importa qual seja o exemplo de engajamento que se tome, tornase vão procurar na deliberação ou no exame dos motivos, aquilo que poderia constituir a essência da liberdade. A verdadeira escolha é aquela que porta sobre nosso caráter inteiro e sobre nossa maneira de serno-mundo - que é fruto da combinação ambígua e, por vezes, contraditória de meu movimento em direção ao mundo e do movimento do mundo em direção 'a mim (do "em - si" para o "para - si"). É a este ponto, afirma M. Ponty, que deve ser reconduzido o centro de gravidade da questão da liberdade.

Porém esta escolha não é fácil de compreender, podendo por um lado, jamais ter tomado consciência de si própria, tendo se imposto, num dado momento, na forma de uma facticidade contingente - o que faria com que minha pretensa liberdade fosse vivida tão somente como o equivalente de um destino.

$\mathrm{Na}$ hipótese contrária, a escolha que eu faço de mim mesmo toma o caráter de "uma verdadeira escolha, uma conversão de minha existência, e assim sendo ela supōe algo já anteriormente adquirido que ela (a liberdade) aplica-se em modificar, fundando dessa maneira uma nova tradição"181.

As duas hipóteses colocam uma questão idêntica. Isto porque certos elementos do caráter do sujeito constituem-se na forma da primeira hipótese levantada - não existe caráter se este não "assimilou" determinados elementos. A questão se recoloca na segunda hipótese, pois o que chamamos de nova tradição não pode simplesmente volatilizar a tradição

180 Caberia aqui uma melhor explicitação da diferença que existe entre consciência espontânea e vontade. Com efeito, enquanto a primeira assume o caráter de uma tradução mais ou menos fiel para o real, do projeto fundamental do sujeito - sua escolha original como o diz Sartre - a deliberação voluntária ao contrário pode transfigurar-se na atitude que "aparentemente" persegue um objetivo que contrarie o projeto fundamental do sujeito.

${ }^{181}$ M.P., p. 501. 
antiga - sem o que a liberdade, "não se opondo a nada, não poderia chegar a se distinguir do que não é liberdade"182, o que implicaria na impossibilidade de qualquer movimento, na morte.

É preciso dessa maneira, considerar a possibilidade de pensar-se uma outra liberdade, cujo conceito afasta-se da proposição inicial, que a identificava a um movimento constante de deslocamento, com a destruição do já adquirido. A proposição é condicional, e implica perguntar-se se não seria este movimento simplesmente o aspecto negativo de nosso engajamento universal; se nossa indiferença em relação a cada coisa determinada não exprimiria tão somente nosso investimento em todas elas; se a liberdade já acabada de onde partimos não se reduz a um poder de iniciativa que não poderia transformar-se em fazer sem retomar alguma proposiçāo do mundo e se, enfim, a liberdade concreta e efetiva não existe nesta troca mesmo ${ }^{183}$.

Mas tal proposição deve repousar sobre uma concepção diferente da significação (tal como explicitado anteriormente). A idéia de que nāo existe sentido e nem valor senão por mim e para mim, uma significação, portanto, centrifuga do sujeito para o mundo deve ser retomada com o objetivo de mostrar que ela pode ser ao mesmo tempo centrifuga e centripeta.

Isso implicaria em última análise em distinguir a qualidade de obstáculo - que é identificada como tal por um sujeito que se coloca um projeto como, por exemplo, o da ultrapassagem de um rochedo - do obstáculo ele mesmo - no caso, o rochedo - reportando-as uma à liberdade e outra ao mundo em si. Mas isto significaria dizer que, além, da própria liberdade, um outro campo atuaria no sentido de colocar obstáculos a ela, limitando-a, pois, do exterior.

\footnotetext{
${ }^{182}$ Waelhens, A. De, p. 317.

${ }^{183}$ In M.P., p. 501.
} 
Porém, se o que chamamos de mundo em si, for considerado como sendo tão somente uma "massa amorfa e não nominável" nas palavras de M. Ponty ${ }^{184}$, sem a liberdade do sujeito para "validá-lo", pois que é ela que condiciona a estrutura do "existe", do "aqui" e do "lá" - tenderiamos a concluir com Sartre que não seria fora do sujeito ele mesmo que se poderia encontrar um limite à sua liberdade.

Mas a questão é que existem duas espécies de atitudes bastante diferentes naquilo que Sartre chama de projeto existencial. $O$ projeto é antes de tudo intenção explícita, e é em relação a esta qualidade característica que os possiveis obstáculos concretizam-se, interpondo-se entre o projeto e sua realização. $O$ projeto de escalar uma montanha faz com que ela se mostre como possivel de ser escalada ou não. Porém, afora esses fins explícitos, o próprio fato de existir implica a produçāo de intenções gerais (não explícitas) que valorizam e significam virtualmente o meio onde vive 0 sujeito. Assim, por exemplo, tenha eu decidido ou não de fazer a escalada dos Alpes, estes me parecerão sempre grandes porque ultrapassam as possibilidades do meu corpo. E a minha percepção deste fato acontece sem que eu tenha que elaborá-lo ao nível de minha razão consciente, pois minha estrutura existencial, meu corpo como facticidade, institui certas relaçōes que se situam marginalmente em face de todo projeto expresso. "Antes de mim mesmo como sujeito pensante,... existe, portanto algo como um Eu natural, que não abandona nunca sua situação terrestre e que esboça sem cessar valorizações absolutas (sendo que), mesmo meus projetos de ser pensante são construídos sobre elas"185.

Cabe concluir dessa forma que o sentido das coisas não é simplesmente construído para mim e por mim, mas, ao contrário, que ele se oferece a nós chegando mesmo a tentar impor-se. Continua, no entanto,

\footnotetext{
${ }^{184}$ M. P., p. 502.

${ }^{185}$ M. P., p. 502.
} 
sendo verdadeira a afirmação de que nada pode ser considerado em si mesmo como obstáculo, trampolim ou meio. Tão somente, o Eu que thes qualifica como tais não é um sujeito acósmico. Ao contrário essas qualificaçōes somente podem proceder de um sujeito mundano pré-pessoal que se "precede ele mesmo junto às coisas para lhes dar o caráter de coisas"186.

Existe um sentido autóctone do mundo, que se constitui no comércio entre ele e nossa existência encarnada, e não é senão a partir de um tal sentido (de caráter histórico/universal) que se pode imprimir sobre as coisas este outro sentido (de caráter individual/singular), o qual se coloca como resultado de nossos livres projetos propriamente "pessoais".

O alcance destes raciocinios ultrapassa a questão da percepção atingindo todo o campo existencial. Assim, se durante uma caminhada numa excursão com amigos, ao final de algum tempo, meu cansaço cresce tanto a ponto de tornar-se penoso para mim, o que faz com que eu näo mais resista e ceda a ele antes de meus companheiros, eles me reprovarão. Subentende-se em minha atitude que eu poderia ter continuado a caminhada se quisesse. Minha escolha é dita livre, no sentido que ela é tal que poderia também ter sido outra: eu poderia continuar a caminhada, como os outros 0 fariam.

Eu me defenderia dizendo estar muito cansado. Somente, como o afirma Sartre ${ }^{187}$, o cansaço, assim como a dor, não poderiam de per-se provocar minha decisão, não podendo, pois jamais ser considerados como causas que agiriam sobre minha liberdade. Ao contrário, "se sinto dor ou cansaço num dado momento, eles não vêm nunca de fora, eles têm sempre um sentido, eles expressam minha atitude em relação ao mundo ${ }^{\text {mb8 }}$. A fadiga que não chega a parar meu companheiro expressa uma certa

\footnotetext{
${ }^{186}$ M. P., p. 503.

${ }^{187}$ Sartre, J.P. - E.N. - p. 508 e seguintes.
} 
maneira de ser-no-mundo marcada talvez pelo gosto e pelo desafio que ele sente em relação à realidade material. Para mim, ao contrário, se ela atua de modo absoluto é porque essa luta não me interessa, visto que eu escolhi estar-no-mundo de uma outra maneira, onde, por exemplo, "eu não procuro estar na natureza, mas sim ser reconhecido pelos outros ${ }^{m 89}$.

Seja como for, o que é preciso salientar é que eu sou livre em relação à minha fadiga na exata medida em que sou livre em ralação ao meu ser-no-mundo: no exemplo citado, sou livre para continuar a caminhar com a condiçāo de transformar meu ser-no-mundo.

Porém, é preciso considerar ainda que minha vida já tem um determinado sentido que é fruto dos projetos por mim já elaborados durante minha existência (lembrando, Lacan diria mesmo anterior a ela). Isto faz com que eu experimente uma certa sedimentação em relação a ela, chegando mesmo um momento onde eu não posso mais escapar de forma absoluta daqueles projetos formados anteriormente - o que inclusive, muitas vezes, eu simplesmente não "quero" mais que aconteça, dada a cristalização de certos modos de ser, certas estruturas interiores, e isso na riqueza ou na miséria.

Desta maneira, não é verdade que a liberdade não sofra qualquer restrição quando colocada em face de uma "atitude privilegiada" do sujeito: "Nossa liberdade não destrói nossa situação (historicamente elaborada), mas, ao contrário, engrena-se sobre ela"190.

A introdução de uma expectativa na qual o individuo se inscreve no interior de um horizonte de facticidade historicamente determinado, - por ele próprio e pelo mundo que o rodeia - implica numa reavaliação do sentido de

\footnotetext{
${ }_{188}^{188}$ M. P. - p. 504.

189 id. ibid. - p. 504.

${ }^{190}$ M. P., p. 505.
} 
liberdade, tal como foi proposto anteriormente. Os elementos principais de composição deste outro sentido de liberdade são: o passado (particular e genérico) e o engajamento (que englobando o presente e o futuro pode assumir variados graus de radicalidade). Com efeito, a questão passa a ser a de mostrar de um lado que a liberdade não se exerce senão sobre um passado que, não assumindo um caráter de fatalidade, detém ao menos um peso especifico pois ele não pode ser considerado tão somente como uma soma de eventos já passados, que se situam bem longe de mim. Eles constituem, ao contrário, a "atmosfera do meu presente"191. Deve-se considerar ainda que o passado tal como nós o descrevemos, nos impele numa determinada direção que se faz valer sem que ela tenha sido propriamente eleita por mim, o que está relacionado ao caráter universal das significações mundanas que em mim se inscrevem pelo fato de eu estar-no-mundo. Por outro lado, trata-se de vislumbrar a possibilidade de transformação dessas significações (universais e singulares) que se encarnam em meu passado, o que nos leva à noção de engajamento militante: pois que se é verdade que minha liberdade pode desviar minha vida de seu sentido "inercial", ela só pode fazê-lo através de uma luta, de um combate.

Merleau-Ponty destaca a dimensão histórica do ser como representando de maneira bastante apropriada o que acabamos da dizer. Ela tem seu início no que podemos chamar de "situaçāo de nascimento" que eu experimento como um fato essencialmente contingente, visto que ela não pode ser fruto de minha escolha. Isto quer dizer que eu nasço operário ou burguês, por exemplo, e que agirei durante muito tempo de maneira prépessoal, (como um outro?) antes de poder escolher ser; ou seja, antes de me constituir numa consciência que se valoriza e se significa "livremente" como consciência burguesa ou consciência proletária ${ }^{192}$. E neste sentido é

\footnotetext{
${ }_{191}^{191}$ M. P., p. 505.

192 Marx, tratando de um tema mais específico, é certo, chega mesmo a afirmar (na Ideologia Alemã), que a classe torna-se independente em relação aos individuos, de tal forma que eles encontram suas condições de vida já previamente estabelecidas, recebendo
} 
falso acreditar que meu modo de vida objetivo acarrete, por uma fatalidade determinista, a tomada de consciência de classe. Porém, se não é o meu lugar no aparelho produtivo que vai determinar minha tomada de consciência, ele ao menos demarca uma linha divisória importante na história, com conseqüências bastante diversas uma da outra, conforme eu me situe como operário ou como burguês.

Antes de tudo, eu existo como operário ou eu existo como burguês, nos afirma um $M$. Ponty ainda parcialmente identificado com o sonho socialista, e é este "modo de comunicação" com o mundo e com a sociedade que pode determinar desde a formação de meus projetos revolucionários ou conservadores, até a estruturação de meus julgamentos explícitos: ou "eu sou um operário" ou "eu sou um burguês" - sem que possamos deduzir os primeiros dos segundos nem os segundos dos primeiros $^{193}$. Ou seja, meus julgamentos explicitos não podem ser deduzidos de meus projetos revolucionários ou conservadores, e vice-versa, pois se assim procedêssemos estariamos conformando o ser do sujeito, à consciência explícita que ele manifesta, bem como aos julgamentos inerentes a esta instância do espirito humano - o que já vimos ser temerário.

É lícito lembrar que Marx alertava em seus escritos não podermos identificar os homens tão somente à representação que eles fazem de si mesmos ou dos outros homens - uma vez que estas representaçöes, mesmo sendo a expressão concreta consciente de suas relações e de suas atividades reais (produção, comércio, organização e comportamento políticosocial) são essencialmente caracterizadas como produtos do imaginário em

de sua classe ainda, totalmente traçada, sua posição na vida e ao mesmo tempo seu desenvolvimento pessoal - daí adviria a imperiosa necessidade de revolução, pois trata-se de lutar contra inimigos que não se sabem burgueses. Mas ai, é claro, coloca-se a questão de quem seriam esses "mocinhos" (o proletariado) e a dúvida corroborada historicamente sobre sua condiçāo de tornar-se senhor de si mesmo, apoiando-se na transformação de suas condiçōes materiais de existência, para além de sua existência concreta. (p. 62, Ed. Sociales, Paris)

${ }^{193}$ Merleau-Ponty, M. - op. cit., p. 506. 
conseqüência do modo fetichizado assumido pela atividade material e das relaçōes sociais estreitas /limitadas que dele resultam.

A questão, porém, deve ser ainda mais aprofundada, pois com o advento da psicanálise, por um lado, e da redução fenomenológica proposta por Husserl com base na noção de intencionalidade, a simples manutenção da divisão dicotômica entre representação e práxis mostra-se como largamente insuficiente para a compreensão do campo humano.

Dado que nada neste campo é desprovido de significado - o que inclui até mesmo as razões pelas quais alguém chega a construir para si uma representação e uma ação-no-mundo que se afaste de seu ser profundo impõe-se buscar pelos pontos de contato (ou de não contato) entre "representação e práxis/projeto e existência".

Este é o procedimento que nos pode permitir um certo acesso, mínimo que seja, aos conteúdos que, contemporaneamente, podemos denominar de sistema inconsciente, os quais, em alguma medida influenciam a práxis do sujeito - dado, por um lado, seu papel de fonte primordial do que chamariamos de ser profundo do sujeito: o conjunto de estruturas significantes que, influenciando as experiências vitais do sujeito, e por elas podendo ser influenciado, balizam toda a sua biografia; por outro lado, seu caráter de depositário privilegiado dos assim chamados conflitos/complexos, cuja origem está afeita ao passado do sujeito, mas cujo objeto (por razões as mais variadas) muitas vezes tende a manter um alto nivel de investimento, permanecendo vivo no sistema inconsciente, mesmo sofrendo reiteradas moçōes de censura por parte do sistema consciente (o que, por exemplo, é o "destino solene" das pulsōes que "não podem" encontrar expressão na existência explícita do sujeito e nem em sua consciência explícita). 
De qualquer maneira, em qualquer dos casos não se pode falar de uma escolha absoluta, sendo suficiente que eu nasça e que eu exista para perceber minha vida difícil e restritiva (por exemplo, no caso de eu viver num meio de exclusão econômica e cultural).

A significação de viver-se num meio de exclusão, sendo um operário, por exemplo, ou muitas vezes nem isso, pode ser descrita de várias maneiras, mas seus contornos mais gerais indicam, a par da restrição material evidente com suas conseqüências conhecidas ${ }^{194}$, uma restrição intelectual, moral e espiritual tão castrante e inibidora quanto a primeira. Quando isso ocorre, esta restrição pode se perfazer de forma mais especifica no que nomeamos como a situação de alienação/heteronomia do indivíduo (a qual parece assumir o duplo caráter de causa e efeito, desde quando passe a "habitar" o espírito do sujeito).

A compreensão profunda desta condição de exclusão por um indivíduo - que passaria a viver explicitamente suas repercussões em cada um de seus projetos e em cada uma das modalidades em que este se apresente - pode significar uma tomada de consciência, que o faça assumir um objetivo transformador pessoal e/ou coletivo - escolha que vai depender em última análise de seu próprio projeto existencial e da qualidade (mas também, intensidade) das circunstâncias históricas que, num dado momento, the emprestaram o colorido.

Porém, se as coisas realmente se passarem dessa forma, essa consciência e esse "destino" a transformar, não constituiriam nada mais que a finalização, como o explica M. Ponty, de um projeto existencial, pois se é

\footnotetext{
194 Aludimos aqui à condição socioeconômica de boa parte do operariado brasileiro raciocinio que, se transplantado às camadas mais especializadas, deva talvez ser relativizado. Mas isto, somente no que diz respeito à condição material imediata, e ainda assim, comparativamente às camadas não especializadas. Mudando-se os critérios, da dimensão material imediata para a dimensão existencial que a abarca, e as bases de comparação (a classe média liberal, por exemplo) esta "avaliação" perderia até seu sentido de ser.
} 
verdade que sou eu quem dá um sentido e um futuro à minha vida, supondo-se, claro, não ser eu apenas um simples agente passivo face ao Destino - isto não quer dizer que este sentido e este futuro sejam por min concebidos num ato de liberdade pura que nasça do nada, ao contrário "eles emergem de meu presente e de meu passado, e em particular de meu modo de coexistência presente e passado ${ }^{\star 195}$.

"Alguém perguntou, certa vez, a Nasrudin o que era o Destino. Disse ele: $O$ que você chama de 'destino' é na verdade uma suposição. Você supõe que algo de bom ou de mal vai acontecer. Ao resultado real você dá o nome de destino".

Isso quer dizer que:

Primeiro, se eu me proponho à transformação de meu ser-no-mundo tendo como projeto nascente (ainda que balbuciante) a autonomia/liberdade (seja qual for o sentido imediato que isto tenha para mim), eu necessariamente tenho que me dispor a re-interpretar o presente ${ }^{196}$ e resignificar o futuro, como única maneira de eu poder re-construir meu projeto existencial, significando-o e valorizando-o diferentemente (em seu conteúdo e, portanto, na forma pela qual eu tendo-ao-mundo, numa combinação entre estes dois termos);

Segundo, o eventual espaço que eu chego a conceder à possibilidade da transformação de meu ser-no-mundo indica, afinal de contas, uma certa escolha que me guia no sentido de experienciar certos "fatores de reequilíbrio". Estes se encontram referenciados, por exemplo, aos conflitos e contradições que me habitam, mas que tiveram quase sempre uma existência obscura - encerrados que foram nas profundezas de meu ser, encontrando-se todavia, como que destinados a aflorar-Ihe à superfície de

${ }^{195}$ Merleau-Ponty, M. - op.cit., p. 510 
modo a representar-lhe, novamente e sempre, seus conteúdos (ainda que de forma disfarçada) num movimento de eterno retorno ao mesmo - quais sejam os mecanismos de repetição a que alude Freud, que se interpõem tanto à recordação quanto à elaboração pelo sujeito. ${ }^{197}$

Mas, poder-se-ia argumentar que nada é verdadeiramente absoluto no Ser que não seja o fruto, em última instância, de sua intencão própria. Assim que, a partir de um dado momento de minha interação com o mundo - talvez quando minha existência seja realmente por mim concebida como inter-ação, o que por suposto acontece ao mesmo tempo que a experiência de minha continência - poderia dar-se uma ruptura (dando lugar à dúvida, à ambigüidade, a ambivalência, à relatividade - ao novo). Aos "fatores de desequilíbrio" então, eu (consciência) permitiria uma explicitação maior com - objetivo de no limite, vive-los novamente e poder assim significá-los diferentemente. Porém, claro está que este processo, bem como aquele descrito anteriormente, não tem uma hierarquia ou ordem necessárias, nem muito menos um fim apoteótico que Ihe seja imanente.

Com o absoluto, portanto podendo ceder lugar ao relativo, a própria fatalidade pouco a pouco tecida pelas moiras fiandeiras, ganha novos contornos podendo ser percebida como inscrita, ao mesmo tempo, no ser das coisas e no ser do homem (no "em-si" e no "para-si"), encarnando-se sim em um ou outro de forma prioritária, mas não se explicando e nem se concretizando nunca total e absolutamente a partir de si própria;

Terceiro, enfim, este movimento de revisão de meu projeto existencial, para que eu possa por ele "optar", deve encontrar apoio em minha própria existência. $O$ que quer indicar que ele não pode nunca nascer do nada, necessitando ao contrário de um motivo anterior que em mim tenha

\footnotetext{
${ }^{196}$ Não existindo um único modo de realizar tal projeto, não existindo nem mesmo a "forma mais correta", uma vez os fins escolhidos, os meios terăo de nascer das próprias possibilidades intrinsecas e extrinsecas ao sujeito (do Eu existencial e do Eu-circunstancial).
} 
se encarnado em virtude da intensidade /qualidade da intenção por ele desencadeada num dado momento de minha experiência (cuja percepção não precisa nem mesmo ter sido vivida explicitamente em minha consciência e nem assim manter-se). Mas nesse caso, pelo menos em princípio, todo homem teria realizado, num momento ou noutro de sua existência, tal experiência? E assim sendo, todos teriam "a priori" a possibilidade concreta de vir a postular sua autonomia? ; supondo-se a existência de circunstâncias situacionais que permitam efetiva e afetivamente vislumbrar a vida de uma outra maneira - restando na seqüência a escolha, o engajamento (ou não) no novo sentido proposto.

A resposta parece-me, tem que ser positiva nos dois casos, desde que se leve em conta as ressalvas feitas anteriormente.

Deve-se, porém, atentar para o fato de que, tão importantes (do ponto de vista afetivo/emocional) quanto os fatores que me impulsionam a fundar minha liberdade numa perspectiva de autonomia/diferenciação frente a outrem, podem ter sido também aquelas experiências que imprimem à minha existência uma força de direção especificamente contrária, ou, o que é mais comum e mais propriamente humano de verificar-se, nela introduzem a ambigüidade e ambivalência que se traduzem em meu caráter e em minha ação-no-mundo, determinados que são (também) pela possibilidade sempre presente de minha alienação/heteronomia, indiferenciação junto a Outrem. A qualidade/intensidade das experiências vividas, portanto parece indicar quase sempre modos de existência híbridos, que se situam num ponto qualquer entre dois pólos extremos.

Podemos agora retornar à questão inicial desta seção: sendo desde o inicio socialmente situado - pois o sujeito não se encontra nunca, nem mesmo idealmente, num momento que o situe para além de seu-ser-no-

\footnotetext{
197 Freud, S. , Recordar, Repetir e Elaborar (Novas recomendações sobre a técnica da Psicanálise II - 1914), Imago, RJ,1969, p.193.
} 
mundo, o que implica, por exemplo, um conjunto de representações ligado necessariamente a esta ou aquela classe social, prioritariamente ao menos a realização da liberdade do sujeito acontece numa relação contínua com seu engajamento militante em um certo pro-jecto. Vivendo-o na sua dimensão particular/individual o sujeito pode, a partir dai, experienciá-lo na dimensão universal/histórica, com implicações maiores ou menores.

No caso de um objetivo de transformação da realidade vivida (desde que ele contenha um certo grau de radicalidade) fruto do que chamamos engajamento militante do sujeito dado que ele se dispõe a lutar por algo, tem-se que atentar para o fato de que, não sendo metafísica, a liberdade tem o poder de transformar um projeto existencial, significando-o e valorizando-o de outra maneira. Ela não pode chegar, porém, a realizar uma nova maneira de ser-no-mundo, ainda que o proponha, que seja radicalmente oposta àquela até então vivida ${ }^{198}$ e nem mesmo produzir instantaneamente o resultado idealizado. Não há mágicas na existência humana.

Quer dizer que, minha decisão de encarnar um determinado lugar social (ou papel) - $x, y$ ou $z$ - não significa tão somente adquirir o que considero como a consciência de ser este ideal. Significa também me valorizar como $x, y$ ou $z$ por "um projeto implícito ou existencial que se confunde com minha maneira de conformar o mundo e de coexistir com os outros ${ }^{4199}$. Queremos estabelecer assim, que minha decisão, seja ela qual for, não faz senāo retomar um sentido "espontâneo" de minha vida - com vistas à sua transformação ou não - o qual essa decisão pode tão somente confirmar ou infirmar, mas nunca anular.

\footnotetext{
198 Aludimos aqui, obviamente, à experiência interior profunda do ser e não à sua explicitação para o outro (o que constitui meu ser-para-o-outro).
} 
Resta ainda realizar uma conexão vital entre a esfera individual e a esfera universal para que se possa vislumbrar, a partir daí, um certo encadeamento das significações e intenções, que possibilite pensar a história.

É preciso conceder de inicio, dentro da perspectiva da facticidade primordial do mundo ${ }^{200}$, que da mesma forma que a subjetividade absoluta não passa de uma noção abstrata e parcial do sujeito, a idéia de um alter-go-objeto absoluto não é senão uma modalidade insincera do outro. Efetivamente, se os outros homens que existem empiricamente devem ser realmente para mim outros homens, é preciso que eu tenha como reconhecê-los como tais, "é preciso, pois, que as estruturas do 'para-o-outro' sejam parte constitutiva das dimensões do 'para-si"n201. Mesmo se destas o sujeito tente fazer abstração, como que querendo desconhecê-las, dada uma certa disposição narcísica caracterial.

Deriva-se daí que mesmo na reflexão mais radical é preciso perceber em torno da individualidade absoluta do sujeito, algo assim como uma aura de generalidade ou uma atmosfera de sociabilidade como diz Merleau Ponty: "é preciso que a vida (do sujeito) tenha um sentido que ele não constitui, que exista a rigor uma intersubjetividade, que cada um seja ao mesmo tempo um anônimo no sentido de individualidade absoluta e um anônimo no sentido da generalidade absolutan202.

Somente nessas condiçōes é possivel conceber-se um sentido da história, uma verdade histórica. Se, ao contrário, a liberdade do sujeito fosse absoluta e sua consciência puramente "para-si", a história não comportaria

\footnotetext{
${ }_{200}^{100}$ M. Ponty - op. cit., p. 511.

200 Um "a priori mundano" que coexiste com um "a priori subjetivo" durante todo o desenvolvimento da experiência do sujeito no mundo, como o caracteriza Duffrenne, M., in L'Inventaire des A Priori. A La Recherche de L'Originaire - Paris.

201 M. Ponty, op. cit., p. 511.

200 M. P., p. 512.
} 
nenhuma estrutura, pois tudo poderia acontecer a partir de tudo (dado que tudo teria seu começo e fim no sujeito ele mesmo).

Sendo evidente que a história não existe per se, necessitando, ao contrário, de consciências que a assumam e que, por fim, dêem uma direção a ela, não há sentido em concebê-la como uma força excêntrica aos sujeitos que deles disporia livremente: "justamente porque ela é sempre história vivida não se pode recusar-lhe um sentido ao menos fragmentário"203. Mas o que Merleau Ponty chama de "sentido dos acontecimentos" não pode reduzir-se a uma idéia que os engendraria, como em Hegel, nem mesmo ao resultado meramente contingente/fortuito de sua conjugação (dos acontecimentos).

O sentido da História se construiria através do projeto concreto de um futuro que se elabora na coexistência social e no "impessoal coletivo" antes da intervenção de qualquer decisāo pessoal ${ }^{204}$ - mesmo que em sua origem absoluta encontremos sempre os sujeitos singulares com suas experiências mundanas. Dai a validade da noção de verdade histórica. Não porque esta se situasse independentemente dos projetos e avaliaçōes livres dos sujeitos concretos, mas sim porque existiria como que uma significação mediana e quase estatística desses projetos - a qual, mesmo estando colocada nos vários projetos individuais, deles parece se independentizar.

Estas consideraçōes nos remetem a uma das proposiçōes mais caras desenvolvidas por Merleau-Ponty, qual seja o caráter, ao mesmo tempo, centrifugo e centrípeto das significações. Esta interpretação, de um lado, afasta-se de uma rígida perspectiva solipsista, na medida em que as significações, não sendo concebidas tão somente a partir de um caráter centrifugo implicam que o verdadeiro sujeito da história não é o individuo. Realmente, um único indivíduo não é suficiente para compor a trama de uma

\footnotetext{
2003 M. P., op. cit., p. 512.

${ }^{204}$ M. Ponty, op. cit. p. 513.
} 
determinada situação e nem mesmo para desenhar as linhas de força a partir das quais uma decisão intervirá. Por outro lado, ela não perde de vista a ecceidade, pois que vê como insensata toda tentativa de exclusão dos individuos da história, pois são eles que, juntos, fazem surgir a direção que num dado momento apresenta-se a um dentre eles para que ele a ratifique mesmo se, como perspectiva histórica possível, essa direção tenha cessado de ser 0 fruto dos esforços de $x$ ou $y$, para tornar-se a "imagem de uma situação", um horizonte de fato.

Existe, portanto, uma troca como propúnhamos logo no inicio desta secção, entre a existência genérica e a existência individual, cada uma dá e recebe. $O$ que equivale a integrar (ou re-integrar) na existência humana, dentro da perspectiva fundada por Heidegger no "Ser e o tempo" por exemplo, os dois modos pelos quais, primordialmente, o sujeito se relaciona com o mundo:

- a facticidade, ou seja, o mundo como anterior ao sujeito, um todo já dado onde ele se instaura.

- o projeto existencial, onde o sujeito, destacando-se de sua contingência mundana, volta-se para o futuro, para o tempo que ainda será, imprimindo-lhe uma direção, um colorido.

Esta análise, vale lembrar, retoma também a noção do duplo "a priori" que, segundo Dufrenne M. (op. cit.), baliza a existência do homem - um a priori objetivo/mundano, e um a priori subjetivo.

O que nos mostra o discurso precedente é que é preciso reconhecer em torno de nossas iniciativas - que provêm, é certo, de um projeto rigorosamente individual que é nosso - uma "zona de existência generalizada e projetos já feitos que se deslocam constantemente entre nós $e$ as coisas e que nos qualificam como homem, como burguês ou como 
operário $^{\text {205 }}$, antes que possa haver de nossa parte uma disposição consciente lexplícita em um ou noutro sentido. Sendo necessário observar ainda que esta perspectiva compōe não somente o cenário inicial de nossa vida, abarcando-a ao contrário por inteiro.

Isso porque fica claro que desde sempre não existe uma subjetividade pura (ou a consciència pura) que se dirige ao mundo em função de seu próprio arbítrio, e dele faça abstração por um ato de vontade pura permanecendo como que em suspenso no nada (ou voltada sobre si mesma).

A idéia da "individualidade narcísica" das experiências do sujeito citada a pouco esbarra num fundo de generalidade que compõe o horizonte mundano onde tem lugar estas experiências. Em nenhum momento, por exemplo, a reflexão se instaura sobre uma consciência pura: ela é sempre reflexão de uma subjetividade engajada no corporal e no mundo (o que quer dizer, qualificada de inúmeras maneiras, notadamente pela sua inserção nas diversas dimensões do mundo cultural). Meu Eu próprio bem como minhas decisões só podem surgir e concretizar-se sobre o pano de fundo de minha existência pré-pessoal, corporal e social ${ }^{206}$.

A liberdade, portanto não é nunca total, pois ela não existe "a despeito de mim mesmo". Ao contrário, ela toma apoio e escolhe a partir de meu ser total e na forma pela qual se dá meu engajamento universal.

Mas o que é então a liberdade, pergunta Merleau-Ponty, se a consciência, longe de ter o poder de constituição universal, não escolhe de forma absoluta nem seu ser, nem sua maneira de ser - visto que é preciso nascer para ser.

${ }^{205}$ M.P., p. 513.

${ }^{206}$ Waelhens, A. De, p. 326. 
O mundo se encontra já constituido, mas também, jamais completamente constituido. Sob a primeira relação somos solicitados, sob a segunda estamos abertos a uma infinidade de possiveis. Mas, (....) existimos sob as duas relações ao mesmo tempo. Não existe, portanto jamais determinismo e jamais escolha absoluta, não sou nunca uma coisa, nem uma consciência nua. ${ }^{207}$

Assim, minha consciência se vai tornando "para-si" em função de um processo que parte do experienciar contínuo das forças macro e microcósmicas que, encontrando-se, de início, contingencialmente mais ou menos próximas de meu ser, nele imprimem significações com maior ou menor intensidade a cada novo instante. Este processo, em minha vida propriamente "livre", se traduzirá na interação de minha liberdade com minha contingência, ou pelo menos com aquilo que eu experimento como tal - o que vai conferir aos elementos contingentes um caráter subjetivo particular que por vezes vai se sobrepor ao seu caráter mais propriamente objetivo/circunstancial, por força da ação do que Castoriadis vai chamar de "imaginário radical".

Cabe pensar, portanto, o caráter do processo que pode levar à instalação em meu ser de novas. significações e valores, que poderão acarretar uma transformação de meu modo de estar-no-mundo. Em qualquer dos casos, tratar-se-á sempre de uma escolha, e ela poderá estar referenciada, por exemplo, à forma através da qual meu projeto existencial encontra expressão na atualidade - o que iria muito mais no sentido da reprodução ampliada das modalidades que conformam meu ser presente, cujas escolhas que the dão substância situam-se em algum lugar de meu passado. Constituindo-se, portanto, numa continuidade sempre reafirmada através de uma ligação primordial com o que já foi (e que assim continua sendo) esta "opção" não chegaria a se caracterizar como tal visto não dar lugar ao novo, ao inusitado, àquilo que ainda não é.

\footnotetext{
${ }^{207}$ M. Ponty, op cit., p. 513.
} 
Dada, porém, a possibilidade concreta de que meu projeto, em suas origens, comporte também um desejo genuino (latente) no sentido da transformação de minhas modalidades de inserção no mundo ${ }^{208}$ - o que se caracterizaria, por exemplo, na atualidade, por um certo descongelamento e não rigidez caracterial frente a posturas e questōes tanto cotidianas quanto vitais. Neste sentido, o movimento de escolha das significações que em mim se encarnam abrigará também a possibilidade de opção por aquelas que propiciariam o que podemos chamar de um processo de "aprofundamento do desequilibrio de minhas certezas estabelecidas" - atitude que deve ser pensada, por ser assim sentida, muito mais como a escolha de significações que me hão de habitar justamente por melhor se adequarem ao novo sentido que desejo dar ao meu projeto existencial, operando, portanto, favoravelmente para a construçäo de um outro equilíbrio.

Seria necessário lembrar ainda que, na mesma medida em que meu projeto alimenta essas novas significaçōes, ele também thes serve de alimento, o que ocorre num processo espiral - e não ciclico - de interação quase sempre experimentada como contraditória - pois que um novo projeto com novas significações contém, essencialmente, a ambigüidade - mas, de qualquer forma, sempre em "acordo" com algum dos momentos de meu serno-mundo.

Aquele que insiste não perceber esse enquadre e a necessária distinção entre figura e fundo não conseguirá nunca compreender que os diversos eventos de uma vida fazem parte de encadeamentos de causas e efeitos distintos. De fato, qualquer pessoa que tenta agrupar todas as cadeias de eventos num só fluxo, que tenta fazer de todas as histórias que compöem uma vida, uma só, e única e longa história; qualquer pessoa que

\footnotetext{
${ }^{208}$ Desejo esse que estaria intrinsecamente ligado a uma perspectiva de autonomia do sujeito, a que nos referimos anteriormente.
} 
se vangloria ao erigir como princípio estar cumprindo um destino único, deverá defrontar-se, como conseqüência dessa postura, com situações que não serão um "teste", como se poderia de modo arrogante supor, de sua humildade e de sua paciência, mas sim o pagamento por sua estupidez. $\mathrm{Na}$ realidade, aqueles que teimam em acreditar estar sempre submetidos a uma prova quando, na realidade, recebem o salário derivado de suas atitudes, sofrem da doença do orgulho. Esse orgulho os impede até mesmo de imaginar que eles possam colher, num momento ou noutro de sua existência, exatamente o que semearam. ${ }^{209}$

${ }^{200}$ Esses considerandos fazem parte do conto "A viagem de Minai", transcrito na sessão Anexos - Contos de Ensinamento. 


\section{TERAPEUEIN - A ATITUDE TERAPÊUTICA COMO PRÁTICA AMOROSA EFICAZ OU DO AMOR COMO PRÁTICA TERAPÊUTICA EFICAZ}

"Era uma bela manhã de fins de novembro. À noite nevara um pouco e o chão estava coberto de um pelame fresco que não tinha mais que três dedos. No escuro, logo depois das laudes, tínhamos assistido à missa num vilarejo do vale. Depois seguimos viagem rumo às montanhas no despontar do sol. Tão logo subimos pela trilha ingreme que se desatava ao redor do monte vimos a abadia.

'Bem-vindo, senhor', disse o despenseiro do mosteiro, 'e não vos admireis se adivinho quem sois, porque fomos advertidos de vossa visita. Eu sou Remigio de Varagine. E se vós sois, como creio eu, frei Guilherme de Baskerville, o Abade precisaria ser avisado.' 'Tu', ordenou voltando-se para alguém do séquito, 'sobe para avisar que nosso visitante está para adentrar os muros.'

'Agradeço-vos: senhor despenseiro' respondeu cordialmente meu mestre, 'e tanto mais aprecio a vossa cortesia quanto para saudar-me interrompestes a perseguição. Mas não receeis, o cavalo passou por aqui e dirigiu-se para o atalho da direita. Não poderá ter ido muito longe, porque chegado ao depósito de estrume precisará deter-se. É inteligente demais para lançar-se escarpa abaixo...'

'Quando o vistes?', perguntou o despenseiro.

'Na realidade não o vimos, não é, Adso?', disse Guilherme voltando-se para mim com ar divertido. 'Mas se estais à procura de Brunello, o animal não pode estar senão onde eu disse.'

O despenseiro hesitou. Olhou Guilherme, em seguida o atalho, e por fim perguntou: 'Brunello? Como sabeis?'

'Vamos', disse Guilherme, 'é evidente que andais à procura de Brunello, o cavalo favorito do Abade, o melhor galopador de vossa escuderia, de pêlo preto, cinco pés de altura, de cauda suntuosa, de casco pequeno e redondo mas de galope bastante regular: cabeça diminuta, orelhas finas e olhos grandes. Foi para a direita, estou vos dizendo, e apressai-vos.'

O despenseiro teve um momento de hesitação, depois acenou aos seus e tomou o atalho à direita, enquanto nossos mulos recomeçavam a subir. Quando estava para interrogar Guilherme, porque tinha sido mordido pela curiosidade, ele fez-me um sinal para 
esperar: e de fato alguns instantes depois ouvimos gritos de júbilo, e na cunva do caminho reapareceram monges e fâmulos conduzindo o cavalo pelo cabresto. Passaram por nós continuando a nos olhar um tanto aturdidos e nos precederam em direção à abadia...

(....) 'E agora dizei-me', não pude me controlar por fim, 'como conseguistes saber tudo isso?' 'Meu bom Adso', disse meu mestre. 'Durante toda a viagem tenho te ensinado a reconhecer os traços com que nos fala o mundo como um grande livro. Alan das llhas dizia que

$$
\begin{aligned}
& \text { 'omnis mundi } \\
& \text { creatura quase } \\
& \text { liber et pictura } \\
& \text { nobis est in } \\
& \text { speculum' }
\end{aligned}
$$

e pensava na inexaurivel reserva de símbolos com que Deus através de suas criaturas nos fala da vida eterna. Mas o universo é ainda mais loquaz do que pensava Alan e não só fala das coisas derradeiras (caso em que o faz sempre obscuramente), mas também daquelas próximas, e nisto é claríssimo. Quase me envergonho de repetir aquilo que devias saber. No trevo sobre a neve ainda fresca, estavam desenhadas com muita clareza as marcas dos cascos de um cavalo que apontavam para o atalho à nossa esquerda. A uma distância perfeita e igual um do outro os sinais indicavam que o casco era pequeno e redondo, e o galope bastante regular - disso então deduzi a natureza do cavalo, e o fato de que ele não corria desordenadamente como faz um animal desembestado. Lá onde os pinheiros formavam como que um teto natural, alguns ramos tinham sido recém-partidos bem na altura de cinco pés. Uma das touceiras de amoras, onde o animal deve ter virado para tomar o caminho à sua direita, enquanto sacudia altivamente a bela cauda, trazia presas ainda entre os espinhos longas crinas negras... Não vais me dizer afinal que não sabes que aquela senda conduz ao depósito do estrume, porque subindo pela curva inferior vimos a baba dos detritos escorrer pelas escarpas aos pés do torreão meridional, enfeando a neve; e do modo como o trevo estava disposto, o caminho não podia senão levar àquela direção.' 'Sim', disse, 'mas a cabeça pequena, as orelhas pontudas, os olhos grandes...'

'Não sei se os tem, mas com certeza os monges acreditam piamente nisso.

'Está bem', disse, 'mas por que Brunello?'

'Que o Espirito Santo te dê mais esperteza que a que tens, meu filho!' exclamou o mestre. 'Que outro nome lhe darias se até mesmo o grande Buridan, que está para tomar-se reitor em Paris, precisando falar de um belo cavalo, não encontrou nome mais 
natural?'

'Porém', disse eu, 'quando vós lestes as pegadas sobre a neve e nos ramos, ainda não conhecíeis Brunello. De certo modo os rastros nos falavam de todos os cavalos, ou pelo menos de todos os cavalos daquela espécie. Não devemos então dizer que o livro da natureza nos fala só por meio de essências, como ensinam muitos insignes teólogos?'

'Não de todo, caro Adso', respondeu-me o mestre. 'Com certeza o tipo de pegadas me exprimia, se assim o queres, o cavalo como verbum mentis, e o teria expresso assim em qualquer lugar que - encontrasse. Mas a pegada naquele lugar e àquela hora do dia dizia-me que pelo menos um, entre todos os cavalos passiveis, passara por ali. De modo que eu me encontrava a meio caminho entre a apreensão do conceito de cavalo e o conhecimento de um cavalo individual. Em todo caso, o que sabia do cavalo universal me era dado pelo rastro, que era singular. Poderia dizer que naquele momento eu estava preso entre a singularidade do rastro e a minha ignorância, que assumia a forma bastante diáfana de uma idéia universal. Se tu vês alguma coisa de longe e não entendes o que seja, contentar-te-ás em defini-la como um corpo extenso. Quando se aproximar de ti, defini-la-ás como um animal, mesmo que não saibas ainda se é um cavalo ou um asno. E por fim, quando estiver mais perto poderás dizer que é um cavalo, mesmo que não saibas ainda se Brunello ou Favello. E somente quando estiveres à distância apropriada verás que é Brunello (ou esse cavalo e não outro, qualquer que seja o modo como decidas chamá-lo). E esse será o conhecimento pleno, a intuição do Singular. De modo que eu, há uma hora atrás, estava pronto a esperar qualquer cavalo, e não pela vastidão do meu intelecto, porém pela exigüidade da minha intuição. E a fome do meu intelecto só foi saciada quando vi o cavalo singular que os monges traziam pelos arreios.

Só então soube, realmente, que meu raciocinio anterior conduzira-me para perto da verdade. De modo que as idéias que eu usava antes para figurar-me um cavalo que ainda não vira eram puros signos, como eram signos da idéia de cavalo as pegadas sobre a neve, e usam-se signos e signos de signos apenas quando nos fazem falta as coisas. ${ }^{1210}$

$\mathrm{Na}$ carona dessa recordação metodológica envolvendo as relações de complementaridade, mas também a hierarquia existente entre a

\footnotetext{
${ }^{210}$ Eco, Humberto, O Nome da Rosa, pp. 37-9 - grifos nossos.
} 
universalidade dos conceitos nascidos hipotético-dedutivos e a concreção do singular, voltamos ao foco principial deste trabalho: 0 individuo singular, adolescente em situação de vulnerabilidade social e sua familia, de quem nos propomos promover a saúde, guiados por uma certa idéia do sentido que deve ser dado à educação para a saúde, sentido esse que vem sendo estabelecido no decorrer de toda a tese. Nessas proposições queremos deixar claro a existência de uma distinção essencial entre o que são os fins visados numa intervenção junto a adolescentes e os meios utilizados para isso.

Comecemos pelo sentido da palavra grega, terapeuein, que dá título a este capitulo: cuidar/curar, ocupar-se do bem estar de alguém, aplicar-se com minúcia. Em nossa perspectiva, cuidar/curar o indivíduo singular, cuidar esse vinculado ao seu desenvolvimento interior como forma de propiciar sua real autonomia e dai também o real emponderamento da comunidade de indivíduos onde ele existe e funciona. "Real", pois forjados - tanto autonomia como emponderamento - em acordo com os valores e princípios descritos até aqui. Estes são conscientemente assumidos, quer dizer, enquanto aspiração que, determinada, mas, ao mesmo tempo, pacientemente, tenho a possibilidade de fazer prevalecer em minha vida, dia após dia - a despeito das contraditórias idas e vindas que me percebo realizando e da miríade de desejos que me assolam - enquanto termos de referência que balizem meu pensamento e conduta, atitude interior/exterior, a intenção. Por comportar a contradição e ambigüidade, ambas fruto do livre arbitrio que nos acomete a todos como possibilidade de liberdade e fardo, acrescida às condições concretas de existência por demais vinculadas, talvez, ao império da natureza/necessidade, há, justamente, que garantir especial cuidado, atenção e minúcia ao processo de educação para a saúde de adolescentes em situação de vulnerabilidade social e suas famílias.

Estão presentes nesse trecho, segundo meu entendimento, alusões aos fundamentos do melhor da atitude terapêutica: a recordação da intenção; a 
disciplina, distante de uma desmedida e severa auto-crítica a que somos capazes de chegar; temperada pela paciência - que nada tem a ver com auto-indulgência - em fazer prevalecer certo conteúdo escolhido por sobre outros possiveis, socialmente valorizados até e, no mais das vezes, absolutamente à mão; enfim, a tensão positiva estabelecida naqueles que interpōem entre si a verdade e interpōem entre si a paciência - que parece acompanhar parte importante do processo de desenvolvimento humano.

Como pode o Amor nos ajudar nessa empreitada?

Já nos ocuparemos dessa questão, mas antes disso cabe fazer uma avaliação do caminho trilhado até este ponto da tese. Partimos de uma indicação forjada pelo professor Lefevre, que dizia respeito a uma condição necessária a ser realizada por individuos singulares no processo de recuperação de sua saúde-doença, qual seja: o estabelecimento e aprofundamento de uma relação intra-individual. Passamos a examinar em detalhe o sentido profundo dessa idéia, bem como os co-determinantes da empreitada proposta através, sobretudo, das noçōes vinculadas à formação do Homem na antiguidade grega - a Paidéia. Essa idéia central foi relacionada à massa de condicionamentos que permeia a vida de cada individuo desde o nascimento, e dai a suas possibilidades de alienação e de liberdade. Esses caminhos foram percorridos em torno de uma interrogação constante acerca do poder e capacidade desses indivíduos, adolescentes em situação de vulnerabilidade social e nós mesmos enquanto propositores desse seu emponderamento, primeiro perceberem sua história e, segundo, reescreverem-na tendo como ponto de partida as bases mesmo que os conformam, sem, no entanto, submeterem-se a elas.

Lembremos que tudo quanto foi até aqui tratado teve como único objeto o esclarecimento de algumas das condições que permeiam o processo de tornar-ser de cada adolescente em sua condição universal e mais particularmente daqueles vivendo com suas familias em situação de 
vulnerabilidade social.

Voltemo-nos agora para a descrição do Amor compreendido neste momento como instrumento de trabalho. Numa ponte com o postulado na sessão "Objeto de Estudo", se permanecermos no âmbito de percepção das realizações exteriores humanas - também quando de uma intervenção visando à promoção da saúde de adolescentes no que respeita o uso e abuso de substâncias psicoativas - então, nos é satisfatório descrever o amor enquanto inclinação/tendência em direção àquilo que é agradável, ponto! Encontramos essa perspectiva tratada por todos os convivas que, n'O Banquete, fazem o elogio do Amor em suas diversas molduras, e em relação aos quais Sócrates, ao tomar a palavra, afirma terem permanecido numa postura insincera, enquanto que: "eu (Sócrates) acreditava que se devia dizer a verdade (....), mas não era esse, aparentemente, o modo correto de elogiar, mas sim o fato de atribuir ao objeto (no caso o amor) o maior número de qualidades $e$ as mais belas, tenham ou não algo a ver com a realidade". ${ }^{211}$

Assim, por exemplo, Agaton enfatiza a juventude e delicadeza do amor, ademais de sua proporção de formas, a qual "o Amor possui em sumo grau, uma vez que, entre a deformidade e o Amor sempre existe guerra mútua". (194d) Ou, mesmo quando Agaton discorre sobre as virtudes do Amor, prenhe de justiça, pois "quando obra, o Amor não exerce violência, dado que todos o servem de bom grado". Acontece que a moderação, valentia, essas aretai, afirma Sócrates, não correspondem ao Amor em si nem descrevem suas obras.

Ao não nos determos no âmbito da emulação de virtudes específicas, nem no discernimento quanto à maneira como se ama; ou ainda se o objeto do amor consiste em algo transitório (o corpo) ou algo estável (a alma); se não nos detemos no deleite daquilo que, de uma história pessoal, tenha sido 
recuperado como que por decantação, e se haja transformado em hábitos e costumes mais ou menos distanciados do Amor em si, e com o tempo tenham se tornado dificilmente discerniveis enquanto atributos acessórios que são, então temos primeiramente que nos aproximar do discurso de Sócrates para compreender a natureza essencial do Amor. Para fazermos isso temos que lembrar que ele faz uso das palavras de Diotima de Mantinéia, que o guia na compreensão do que, verdadeira e agora sinceramente, é o Amor. Esta o coloca, antes de tudo, como daimon situado entre os deuses e os homens, filho da Pobreza (Penia) e do Recurso (Poro), concebido quando do nascimento de Afrodite, o Amor é seu acólito e escudeiro e ao mesmo tempo enamorado pelo belo. Porém,

(....) é sempre pobre e está longe de ser delicado e belo, como o supõe o vulgo; ao contrário, é rude e esquálido, anda descalço e carece de um lar, dorme sempre no chão e sem cama, deitando-se no sereno nas portas e nos caminhos, pois por ter a condição de sua mãe é sempre companheiro inseparável da pobreza. Por outro lado, dada a condição de seu pai, vigia aos belos e aos bons, é valente, intrépido e diligente; caçador temivel, que sempre urde alguma trama; é apaixonado pela sabedoria e fértil em recursos; filosofa ao largo de sua vida e é um terrivel charlatão, um embelezador e um sofista. Por sua natureza não é imortal nem mortal, num mesmo dia em alguns momentos floresce e vive, se tem abundância de recursos, em alguns momentos morre e novamente volta a reviver graças à natureza de seu pai. O que ele busca porém, sempre escorrega de suas mãos, de modo que o Amor nunca é pobre nem tampouco rico. Encontra-se no meio termo entre a sabedoria e a ignorância. (202c/d)

Diotima "ensina", assim, a Sócrates corrigindo a "idéia errônea que te havias forjado sobre o Amor", apontando ainda a essência de seu erro: "Imaginas-te, (....), que o Amor era o amado e não o amante. Por esse motivo, creio eu, te parecia sumamente belo o Amor, pois é o amado que, na realidade, é belo, delicado, perfeito e digno de ser tido por feliz e invejável." (203c/d).

Desse estado dão conta alguns poemas de Rumi aos quais vale a pena nos

${ }^{211}$ El Banquete, o Del Amor - 197e, Platāo, Obras completas, Espanha, Ed. Aguillar. 
referirmos tamanha é sua força ilustrativa.

“Contentar-se é uma coisa,/amar é bem diferente;/quem preza sua cabeça/não tem corpo para amar.,...,

Chegasse a este mundo uma fênix,/o amante a veria como sombra/da ave de sonhos de que já está enamorado" ....

(O amante - Divan de Shams de Tabriz, Rumi, p.164)

E ainda,

“O amantes abandonai as tolas ilusões./Perdei de vez a cabeça./Erguei-vos do fogo ardente da vida/- tornai-vos pássaros, sede pássaros!...

...Os pensamentos só te levam aonde lhes apetece./Queres seguilos?/Melhor é seguir teu destino/- toma-te quia, sê teu próprio quia!

Paixão e desejo prendem teu coração?/Remove pois estas travas/toma-te chave, sê a chave!...

Por quanto tempo mostrarás duas faces?/Até quando trairás a ti mesmo,/submisso como bandeira ao vento?/Não te cansa ser o bispo do xadrez/a andar o tempo todo de viés?/- toma-te sábio, ó sábio!...

O pregador, até quando clamarás dos tetos/e baterás à porta alheia?/Olha para o interior da tua própria casa./Já falaste do amor em demasia/- agora toma-te amante, sê o amado!" (Toma-te o amante - Divan de Shams de Tabriz, Rumi, p.115/6/7 - grifos nossos)

Ao amante cabe, portanto, elevar-se do plano das realidades visíveis; ele deve começar pelas coisas belas deste mundo e, valendo-se delas, deve:

ascender constantemente, indo de um só corpo,(....) a todos os corpos belos e destes às belas normas de conduta, e destas às belas 
ciências, (....) até chegar a essa ciência de antes (a 'ciência da unidade' como ele chama em $211 \mathrm{a} / \mathrm{b}$ ), que não é ciência de outra coisa senão da beleza absoluta, e chegar a conhecer por último o que é a beleza em si. (211 e/212 a)

Em outras palavras:

"Os olhos foram feitos para ver coisas insólitas, fez-se a alma para gozar da alegria e do prazer./O coração foi destinado a embriagar-se/na beleza do amigo ou na aflição da ausência.

A meta do amor é voar até o firmamento,/a do intelecto, desvendar as leis e o mundo./

Para além das causas estão os mistérios, as maravilhas./Os olhos ficarão cegos/quando virem que todas as coisas/são apenas meios para o saber.

O amante, difamado neste mundo/por uma centena de acusações,/receberá, no momento da união,/cem títulos e nomes.

Peregrinar nas areias do deserto/nos exige suportar/beber leite de camelo,/ser pilhados por beduínos.

Apaixonado, o peregnino beija a Pedra Negra/ansioso por sentir mais uma vez/o toque dos lábios do amigo/e degustar como antes o seu beijo.

O alma, não cunhes moedas com o ouro das palavras:/o buscador é aquele que vail à própria mina de ouro."

(O destino do coração - Divan de Shams de Tabriz, Rumi)

Dizer isso significa continuar assumindo que a natureza essencial do amor define-o como uma inclinação em direção ao agradável sim, afinal, amamos o que produz deleite, em primeiro lugar, a cada um dos cinco sentidos. $^{212}$ Mas significa também que existe como que uma escala ascendente nesse agradável e nesse deleite que nos leva, se assim o quisermos, de um patamar mais baixo... ao mais alto. Pois, se concordamos

${ }^{212}$ Al-Ghazzali, La alquimia de lá felicidad, Editorial Sufi, Madrid, 1983, p. 128. 
que "cada uma das faculdades humanas tem uma função própria a qual ele se deleita em cumprir", então tal afirmação deveria compreender todas e cada uma dessas faculdades, do mais baixo apetite corporal até a mais alta forma de compreensão intelectual. Sendo que, quanto mais alto esteja situado nosso objeto de conhecimento, maior será a satisfação que ele tende a nos proporcionar. A culminância desse processo ascendente seria conseguida, na concepção socrática, com o reconhecimento ou ciência da unidade, na realidade sempre existente, entre tu e eu, amante e amado, na linguagem do poema de Rumi.

Nesse sentido, eleger o foro interior, o intra-individual, como uma base importante do trabalho de promoção da saúde de adolescentes e suas familias em situação de vulnerabilidade social, significa nos afastarmos de qualquer intervenção pautada na produção de grande excitação emocional ou qualquer fervor pseudo religioso, que dura tanto quanto a fanfarra estiver tocando, e mesmo de certos deleites arte-educacionais que não mantenham subjacente seu comprometimento com o que temos chamado de intenção. Ao contrário, acreditamos que o esforço principal consiste em dar suporte a esses adolescentes e suas familias e propiciar o desenvolvimento de algumas de suas qualidades e algumas das possibilidades - que já se encontram neles mesmos, pois constituem seu conjunto de caracteristicas que o fortalecem a par daquelas que o fragilizam, qual seja o dote de todo homem. Ajudando-o, ao mesmo tempo, a saber quando e como empregar essas possibilidades, em que momento e em que proporção. Isto porque há que se compreender que cada indivíduo tem as aptidões necessárias e a capacidade de refletir, examinar e elaborar as coisas que podem ser utilizadas a seu favor, dadas as circunstâncias que o envolvem e seu histórico sim, mas sobretudo dado seu pro-jecto que implica desde o pensar em si mesmo, pensar no que ele está fazendo em sua vida, no que fizeram em sua vida, pensar no que ele gostaria de fazer da sua vida, pensar, enfim, no que ele pode efetivamente fazer com ela. 
Trata-se de almejar produzir uma melhoria tal, quando de uma intervenção de promoção da saúde junto a adolescentes e suas famílias, que não se esgote nas situaçōes de acesso a uma renda familiar adequada que, sabe-se possibilitar, por exemplo, a melhoria de seu estado nutricional e a segurança alimentar da família; acesso aos serviços de saúde, que mitiga os sofrimentos presentes, previne os futuros, favorece a longevidade; acesso à ajuda social; acesso à educação, alfabetização e formação contínua, que cria e aumenta as ocasiōes que favorecem seu desabrochar e o tornar-se membros ativos da sociedade na qual vivem. Estamos falando sobretudo de pobreza e iniqüidade e das diversas maneiras de nos contrapormos a seus efeitos. Nesse sentido, é certo que a satisfação das chamadas necessidades humanas mais fundamentais permanece na base do desenvolvimento são das crianças e adolescentes em situação de vulnerabilidade social, sendo que 0 inverso significa, lógica e existencialmente, um obstáculo a seus direitos, seu bem estar e seu desenvolvimento humano. ${ }^{213}$

Comungar desse ideário é, acredito, uma condição sine qua non ao exercício da promoção da saúde. Sua suficiência, entretanto, é que sustentamos deva ser questionada em favor de nossa tese que postula edificar junto ao adolescente uma certeza quanto ao desenvolvimento absolutamente possivel de suas próprias capacidades apoiada, essa certeza, por um conjunto de termos de referência que encontram fundamento em sua unidade interior, seu ser essencial. Encontramo-nos novamente no plano da intenção, onde a dualidade do interior/exterior desaparece, "pois a dualidade está no plano das ramificações, (enquanto que) a raiz é una...

...quando o vento passa por uma casa e levanta os panos, desarruma todos os tapetes, faz os raminhos e as ervas secas voarem, faz a água da lagoa ondular, faz as ánores, os galhos e as

\footnotetext{
${ }^{213}$ Essas indicaçōes fazem parte do “Rapport National - Canadá - L'Étude Decennale du Sommet Mondial pour les Enfants - La Version Jeunessen, 2000, p. 12 e seguintes.
} 
folhas dançarem. Todos esses estados parecem diferentes e distintos, mas do ponto de vista da intenção, da origem e da realidade trata-se de uma coisa só: o movimento provém do vento."

(Rumi, Fihi-Ma-Fihi, op. Cit., p. 48)

Tais propósitos nos levam a um cenário, que soa dramático, de luta árdua a desenrolar-se na vida do adolescente e eventualmente de sua familia, que pede perseverança e, novamente, certa disciplina de pensamento e de ação fundada sobre uma escolha que ele faz por si mesmo, de si mesmo, de sua vida.

Mas é necessário, então, que ele seja lembrado que tem o poder de escolher. Quaisquer que sejam suas condições concretas de existência é imprescindivel que ele reconheça que nada está escrito de modo absoluto. Isso quer dizer que o imbróglio que pode estar a sua vida em termos de falta de pai (física e/ou moral), falta de mãe (que está no batente), falta de comida, falta de espaço (dividido com mais três/quatro/cinco irmãos num cômodo), falta de roupa, de higiene, de grana, de..., falta do amigo. ${ }^{214}$

“(...) Faltam-te pés para viajar?

Viaja dentro de ti mesmo,

E reflete, como a mina de rubis, os raios de sol para fora de ti

A viagem te conduzirá a teu ser, transmutará teu pó em ouro puro.

$(\ldots$.

Pudesse a ánore vagar/e mover-se com pés e asas,/não sofreria os golpes do machado/nem a dor de ser cortada.

\footnotetext{
${ }^{214}$ Sem dramalhão, essa descrição fala bastante bem da condição vivida por bom número de adolescentes que atendemos nos programas de promoção da saúde no Reino da Garotada.
} 
Não errasse o sol por toda a noite,/como poderia ser o mundo iluminado/ a cada nova manhã?

E se a água do mar não subisse ao céu,/como cresceriam as plantas/regadas pela chuva e pelos rios?

A gota que deixou seu lar, o oceano,/e a ele depois retomou,/ encontrou a ostra à sua espera e nela se fez pérola.

Não deixou José seu pailem lágrimas, pesar e desespero,/ao partir em viagem para alcançar/ o reinado e a fortuna?

Não viajou o Profeta/para a distante Medina/onde encontrou novo reino/e centenas de povos para govemar?

Faltam-te pés para viajar? Viaja dentro de ti mesmo, e reflete, como a mina de rubis, os raios de sol para fora de ti.

A viagem te conduzirá a teu ser,Aransmutará teu pó em ouro puro.

Ainda que a água salgada/faça nascer mil espécies de frutos,/abandona todo amargor e acridez/e guia-te apenas pela doçura.

É o Sol de Tabriz que opera todos os milagres:Aoda árvore ganha beleza quando tocada pelo sol."

(Viaja dentro de ti - Divan de Shams de Tabriz, Rumi)

O imbróglio que está sendo a vida de um adolescente, dizia eu, não pode ser percebido como impeditivo o suficiente que barre seu progresso, na base mesmo de sua realidade, apoiando-se sobre ela como pleiteia a formulação de Merleau-Ponty, que seja, mas de qualquer forma imprimindoIhe um novo sentido e direção. Estes, se comprometidos com seu progresso, podem perder a rígida polarização congelante entre interior/exterior, intra-individual/exo-individual; deleite e satisfação/mortificação, pois que, apoiando-se em um julgamento interior, podem voltar-se para a resposta de questões que são simples e profundas ao mesmo tempo: "De que forma meus estados poderão ser melhores?; Como meus progressos poderão ser maiores?" 
Esse é o papel que nos cabe, entendo eu, na condição de sanitaristas promotores da saúde junto a adolescentes em situação de vulnerabilidade social e suas familias: propiciar o acesso, a par de todos os outros acessos, a essa consciência da consciência visando-a racionalmente e de modo lúcido - o que deve abarcar os próprios responsáveis pela intervenção ao nível da intenção; vide o conceito de "intencionalidade operante" em termos fenomenológicos. A esse respeito cabe a seguinte alegoria como lembrança de nossa condição humana, muito humana:

"Um elefante foi levado à margem de um rio para que the dessem de beber. Viu-se na água e ficou espantado. Pensou que fosse um outro elefante que o amedrontasse e não percebia que se espantava consigo mesmo. Todos os defeitos, como a tirania, o ódio, a inveja, a falta de piedade, o orgulho, quando existem em ti, não te causam dor, mas quando os percebes em outrem, te espantas e te sentes atingido. Quando um homem tem sama ou um abscesso, não se enoja consigo mesmo: põe sua mão infectada no prato e lambe os dedos sem achar isso repugnante. Mas, se vê um abscesso ou uma ferida na mão de outrem, é incapaz de comere digerir seu alimento. O mesmo ocorre com os defeitos morais. Quando existem em nós, não nos afetam; assim que os percebemos no outro, ficamos chocados e os vemos como repugnantes."

(Rumi, Fihi-Ma-Fihi, op.cit, p. 49)

A consciência da consciência visada racionalmente não quer dizer fácil, mas sim estimulando a razão. E esse modo de agir definimo-lo sobretudo pelo seu oposto absurdo: uma situação, qualquer situação, não deve ser examinada/tocada "irracionalmente". 
Tomemos como exemplo uma fase do trabalho com adolescentes no Reino - "Projeto de Vida" é o seu nome e tem como um dos objetivos a prevenção ao uso de drogas (vide descrição em Materiais e Métodos) - e sua resposta. Trata-se da quinta oficina de um grupo de oito programadas com adolescentes de 12, 13 e 14 anos, homens e mulheres. Na oficina antecedente começamos a tratar do assunto drogas - tipos de uso (experimental/ocasional/habitual/dependência), dependência física e psicológica, etc.. Nessa ocasião, isso foi feito obedecendo o seguinte caminho: 1)lembrança da oficina anterior (tema: Amor e sexualidade), pedindo que cada participante comentasse o que tinha considerado mais importante/significativo, onde foi enfatizado por alguns a brincadeira de 'vestir a camisinha no pepino'215; por outros as 'mudanças que ocorrem no nosso corpo quando crescemos' ou 'a explicação sobre o corpo humano'; por outros ainda 'o que mais me marcou foi no filme que também falaram de sentimentos', e também 'o que me chamou mais a atenção é que acima de tudo é o respeito';

2)dinâmica 'De quem é a culpa, quando uma pessoa passa a consumir certa droga?', quando, divididos em grupos, pedimos que produzissem argumentos que defendessem as seguintes explicaçōes: a) a culpa é da sociedade - 'a sociedade pensa que só colocar cartazes na parede já é suficiente para eles. Mas não prestam atenção nos movimentos das ruas que acontece sobre as drogas.' Ou 'eles bem que podiam proibir a venda de cigarros ou coisa pior? Eles podiam proibir também de passar filmes com essas cenas ou novelas que dão exemplo para as crianças..., etc.; b) a culpa é dos pais, pois 'não prestam muita atenção em seus filhos', 'falta de carinho, falta de compreensão, ficam sem tempo para conversar com seus filhos por causa do trabalho, falta de respeito entre pais e filhos, por isso os filhos acabam fazendo besteira com drogas e bebidas alcoólicas, também se misturam com más amizades' ou 'a culpa é deles por quererem se preocupar apenas com bens materiais (emprego) e não dar atenção aos filhos e não

\footnotetext{
${ }^{215}$ Daqui para a frente as frases entre aspas constituem trechos dos testemunhos escritos pelos adolescentes eles mesmos, transcritos literalmente.
} 
ajudar na hora que mais precisam de carinho.'; c) a culpa é dos amigos, porque: 'ele bebia para se mostrar para eles, ele fuma por que seus 'amigos' the disseram coisas boas sobre o cigarro, ele usa drogas mais forte por que eles the disseram que ele deveria seintencificar nessa vida.; d) a culpa é da própria pessoa, 'que quis experimentar para saber o gosto da droga; a culpa foi dele por que ele viu um amigo e quis ver como era; por que ele quis usar, e não foi da droga por que a droga não anda, a droga não veio nele, ele que buscou ela.'; 'ele sabia que aquilo não era boa coisa e ele quis'. Cada grupo tinha que defender então seus argumentos frente aos outros grupos e depois pedimos que os grupos trocassem de perspectiva, assumindo a explicação que até então era dada por outros, recompusessem seus próprios argumentos e a defendessem como sendo sua. Depois de poucos momentos de certa angústia, talvez pela lembrança de pessoas próximas enfrentando esse tipo de situação, e um monte de risadas passamos ao conto;

3)conto 'O Homem sem sorte' (vide Anexo Contos).

$O$ assunto nesta $5^{a}$ oficina em particular tinha como foco tratar as caracteristicas das principais substâncias psicoativas, divididas, segundo seus efeitos, entre drogas depressoras (álcool, ansiolíticos, inalantes, opiáceos), estimulantes (tabaco, cafeina, anfetaminas, cocaina/crack) e alucinógenos (maconha, ecstasy, LSD). Esse tópico importante, pois veicula informação junto com formação, e chato, pois dá sono, aconteceu entre duas dinâmicas $-1^{a}$ ) em duplas, deviam contar, alternadamente, até três; na seqüência, dizer o número 1 foi associado, concomitantemente, a 'bater palmas', o número 2 a um pulinho e o número 3 a coçar a cabeça; $2^{a}$ ) divididos em grupos de $4 / 5$, cada membro, alternadamente, permanecia de pé no centro do grupo e se permitia tombar em várias direções, confiando em ser amparado por seus camaradas. Como complemento propusemos 0 seguinte Conto de Ensinamento: 


\section{O Príncipe Adil e os Leões}

Há muito tempo atrás e muito longe daqui, vivia um rei que tinha um filho de quem gostava muito e que se parecia muito com ele quando jovem.

Um dia, o rei Azad disse ao grão vizir:

- Vamos levar meu filho à cova do leão e dizer-lhe o que se espera dele, agora que completou 18 anos.

O príncipe Adil foi chamado à presença do rei e o grão vizir assim the disse:

- Alteza, sempre foi costume nesta nobre familia, quando o herdeiro do trono chega à idade que você tem agora, que ele passe por um certo teste. Isto é para que fique estabelecido sem nenhuma dúvida se o príncipe está apto ou não para ser o futuro govemante do nosso povo. Venha conosco e nós the mostraremos o lugar onde será seu teste.

O príncipe seguiu seu pai e o grão vizir até uma grande porta na parede de uma cova rochosa. Havia ali uma pequena grade na porta, através da qual podia-se ouvir o rugido de um leão.

- Veja, meu filho, disse o rei alisando a barba, ai dentro está um enorme leão criado na floresta. Você deve lutar com ele e submetê-lo com uma adaga e uma espada. Você pode fazer isso quando quiser. Todo homem de nossa familia teve que passar por este teste antes de herdar o trono.

O príncipe olhou pela grade e empalideceu, pois o que ele viu foi de fato um leão muito grande, andando de um lado para o outro de uma caverna cheia de ossos. O animal tinha uma juba espessa e dentes brancos e afiados. De vez em quando, ele franzia o nariz, arreganhava os dentes e dava um rugido horripilante.

- Lutar? Submeter? Matar esta coisa? Como poderei fazer isso? O máximo que consegui até hoje foi matar um veado ou mandar meu falcão caçar um pássaro. Eu tenho certeza de que um leão deste tamanho e com toda esta força está além das minhas possibilidades, dizia o principe quase sem voz.

- Não tenha medo, disse o grão vizir. Você não precisa fazer isso agora. Um dia você poderá fazê-lo, quando se acostumar com a idéia. Pela graça de Allah, você vai encontrar a confiança necessánia, quando tiver pensado um pouco sobre o assunto. Todos os seus antecessores fizeram isso. O rei sorriu e fez um sinal para que um 
escravo jogasse um pouco de came para o leão, que a devorou com satisfação.

Depois disso, os dias se passaram e, embora o rei continuasse tratando seu filho tão gentilmente quanto antes Adil sentia que sua tarefa pesava sobre ele e que seu pai devia estar ansioso para que matasse o leão imediatamente. Ele não conseguia sentir prazer em nada pensando no que tinha que fazer.

Uma noite, depois de virar-se e revirar-se na cama sem conseguir domir, ele se levantou. Vestiu-se, encheu uma bolsa com muitas moedas de ouro e foi até os estábulos reais. Acordou seu escudeiro e pediu-lhe que selasse seu cavalo favorito e que dissesse ao rei que ele ia fazer uma viagem. A lua brilhava no céu e o principe se foi, sem olhar para trás, buscando uma resposta para seu problema.

Na manhã seguinte, chegou à beira de um rio com prados verdejantes dos dois lados. Enquanto o cavalo bebia água, ele ouviu - som de uma flauta e logo em seguida avistou um jovem pastor levando cameiros para o pasto. Adil perguntou-lhe se ali por perto havia algum lugar onde ele pudesse ficar por uns dias. $O$ pastor levou-o ao seu patrão, um homem rico que morava numa casa muito grande. Lá, o homem, que se chamava Haroun, convidou Adil para jantar e perguntou-lhe:

- De onde você vem e como estão seus rebanhos?

O principe respondeu com evasivas, dizendo que tivera certos problemas em casa que o obrigaram a viajar. Disse também que estava buscando uma resposta para uma questão pessoal, pedindo ao velho homem que não lhe perguntasse mais nada.

Imediatamente Haroun disse que Adil poderia ficar em sua casa quanto tempo quisesse e que ficasse à vontade. Seu cavalo foi levado ao estábulo e o príncipe pensou que gostaria de ficar um longo tempo naquele lugar tão tranqüilo. A cada dia descobria um lugar encantador onde se podia ouvir o som das flautas dos pastores, que naquela área eram inúmeros, pois aquela era a Terra dos Tocadores de Flauta Celestiais. Acontece que certa noite, horrorizado, o príncipe ouviu rugidos de leões não longe da casa e contou a Haroun na manhã seguinte.

- Ah, sim, respondeu ele calmamente. Este lugar está infestado de leões. Eles caçam a noite. Fico surpreso de que você ainda não os tivesse escutado. Por isso temos este alto muro em volta do jardim, senão eles já teriam levado toda a minha familia. - E ele ria com gosto, como se tivesse dito uma piada. 
O coração do principe encheu-se de medo. Assim que preparou seu cavalo para partir, despediu-se de Haroun agradecendo sua hospitalidade e, mais uma vez, pôs-se a viajar, cavalgando o mais rápido que podia. À medida que viajava, foi deixando para trás os verdes vales enquanto ia surgindo a sua frente uma árida planície arenosa onde não se via um único tufo de grama. O cavalo avançava com dificuldade, enfrentando o vento que, de vez em quando, levantava nuvens de poeira seca. Adil sabia que precisava logo encontrar água para ambos. Em silêncio rezou para que na próxima duna surgisse um acampamento de beduinos ou um oásis pequeno.

Como em resposta a sua oração ele viu no horizonte uma fila de tendas negras. Vários guerreiros se aproximaram, suas armas reluzindo ao sol, e o saudaram gritando "Assalam aleikum!". Eles o escoltaram até seu chefe que o recebeu calorosamente dizendo-lhe que tinha muita honra em tê-lo como hóspede e que ele poderia ficar quanto tempo desejasse. Depois de uma deliciosa refeição de carneiro cozido, arroz com especiarias, figos e tâmaras maravilhosamente doces, o Sheikh perguntou a Adil que ventos 0 traziam naquela direção.

- Não me pergunte mais nada, disse o príncipe. Basta que você saiba que deixei minha casa com um problema, que espero resolver, tendo me ausentado da casa de meu pai até me sentir mais seguro de minha situação.

O Sheikh inclinou a cabeça, alisou a barba e deu uma baforada no cachimbo - O tempo nos dá todas as respostas, murmurou, se pudermos ser pacientes. O principe sentiu que poderia ficar para sempre naquele lugar, onde, durante o dia, respirava o ar frio e fresco do deserto, caçando antílopes e comendo fartamente na companhia do Sheikh. Mas um dia, depois de duas semanas de tranquilidade, o velho Sheikh lhe disse:

- Meu filho, meu povo e eu gostamos de você e admiramos o modo como se juntou a nós em nossos divertimentos. Mas somos guerreiros e temos que lutar com outras tribos. É necessário ter muita bravura pessoal para nossa sobrevivência, por isso, gostariamos de submetê-lo a um teste onde pudéssemos ter uma evidência do seu valor. A duas milhas ao sul desta área está uma cadeia de montanhas infestada de leões. Levante-se cedo amanhã e, depois da oração do alvorecer, pegue o melhor de nossos cavalos e com uma lança e uma espada mate um destes animais. Depois disso, arranque sua pele e traga-a para nós, assim terá provado sua valentia.

O rosto do príncipe tornou-se branco como cera e enquanto dizia boa noite ao Sheikh, tomado pelo medo, tinha certeza de que não poderia enfrentar aquelas criaturas selvagens. 
- Deus do céu, ele se dizia ao abandonar o acampamento antes da última refeição da noite, parece que encontro leões em todos os lugares para onde vou. Não posso entender, afinal sai de casa justamente para evitá-los.

Viajou muito tempo pela noite estrelada. De manhã chegou a uma bela região onde as flores selvagens cresciam nas montanhas. Avistou ao longe um magnifico palácio, o mais belo que ele jamais vira. Era feito de uma pedra rosada, com colunas de lápis lazuli e balcões de madeira esculpida e pintada de várias cores. Havia fontes nos jardins a sua volta, pássaros que cantavam em árvores cheias de flores e muitos pavilhões cobertos de jasmins e rosas docemente perfumadas.

- Parece um paraíso na terra! disse Adil para si mesmo enquanto se aproximava do palácio.

Nos portões, guardas levaram-no ao quarto de hóspedes onde tomou um banho e vestiu roupas limpas, ajudado por servos sorridentes. Depois, foi conduzido à presença do Emir, um homem de barbas cinzentas que lhe perguntou o que o trouxera ali. Junto dele estava sua filha Peri-zade, que tinha lindos olhos amendoados e um cabelo negro como a cauda de um pássaro.

- Minha situação é tal que não posso falar dela, tentou responder o príncipe, evitando olhar para a adorável Peri-zade, por quem ele tinha imediatamente se apaixonado.

- Eu deixei meu país porque tinha um problema para resolver.

- Eu entendo, disse o Emir balançando a cabeça. E começou a falar de outros assuntos.

Depois da refeição o Emir mostrou a Adil o palácio em toda sua magnificência. Escadas de mármore levavam a aposentos cheios de móveis de madeira de várias partes do mundo. As paredes e o teto eram cobertos de mosaicos de turquesa e ouro, afrescos e espelhos. As janelas eram de vidro transparente pintado em cores delicadas e os tapetes macios como seda, tão bem tecidos e mostrando paisagens tão harmoniosas que quase não pareciam ter sido feitos por mãos humanas. O Emir o levou finalmente a seu quarto para que ele pudesse descansar e the disse que ele ficasse ali o quanto the fosse possivel ficar. Sozinho, olhando todo aquele esplendor a sua volta, Adil pensou que naquele lugar ele poderia ficar o resto de sua vida. 
Muitos dias se passaram. A princesa Peri-zade encantava-se em poder mostrar ao principe os jardins em várias horas diferentes. Um dia, ao entardecer, ele a ouvia cantar e tocar alaúde com extrema graça e perfeição. Foi então que escutou um som que o arrepiou dos pés à cabeça.

- Pare, gritou ele, que som foi este?

- Não ouvi nada, ela respondeu um pouco aborrecida pela interrupção. E continuou a tocar.

- Foi ali, perto de uns arbustos. Parecia o rugido de um leão!

Ela riu e lhe disse: $E$ apenas Rustum, nosso guardião, como o chamamos. É o animal de estimação de toda a corte. A esta hora ele vigia nossos jardins. Eu o conheço desde que era um filhotinho e à noite ele dorme à porta do meu quarto.

Nesta noite, cheio de medo, o príncipe quase não tocou na comida. Quando subiu as escadas acompanhado pelo Emir, quase saiu correndo ao ver o enorme leão parado à porta do seu quarto.

- Veja que honra, disse o Emir. O bom Rustum está esperando para levá-lo para a cama! Ele não faz isso com muita gente, não. Apenas se aborrece se vê que alguém tem medo dele. Mas, na realidade, é extremamente manso.

- Eu tenho medo dele, sussurrou o príncipe, realmente tenho muito medo.

Mas o Emir pareceu não escutá-lo e se despediu, deixando Adil com o leão. O príncipe abriu a porta e, o mais rápido que pôde, fechou-a atrás de si. Não conseguiu dormir a noite inteira. Quando se levantou pela manhã, começou a pensar que seria melhor voltar para casa. Havia tantos leões no seu caminho que seria melhor lutar com o leão na cova e acabar logo com isso, em vez de ficar fugindo a vida toda. Foi até o Emir e lhe disse:

- Peço permissão para partir e enfrentar meu próprio problema à minha maneira, ou então nunca estarei em paz comigo mesmo. Sou um covarde e não quero mais sê-lo, em honra de meu pai. Sou o filho do rei Azad e fugi do dever que todos os homens de minha familia devem realizar. Estou envergonhado e sei que nunca poderei pedir a mão da princesa Peri-zade enquanto não encarar meu destino e lutar com o leão naquela cova.

- Muito bem falado, meu filho, disse o Emir. Desde o primeiro momento eu soube quem você era, pois você se parece muito com 
seu pai quando jovem. Sempre respeitei e admirei o rei Azad. Vá, lute com o leão e eu lhe darei minha filha em casamento.

O principe montou no seu cavalo e galopou até o acampamento das tendas pretas.

- Benvindo, principe Adil, disse o Sheikh beduíno, conheci o seu pai quando tínhamos ambos a idade que você tem agora. Eu pude saber quem você era pela enorme semelhança que você tem com ele, aliás, maior agora de que no dia em que você chegou aqui. Adil contou-lhe sobre sua intenção de voltar para casa, o que muito agradou ao Sheikh. Depois de descansar aquela noite, o príncipe seguiu viagem e descobriu, no caminho, que estava com muita saudade de casa, com leão e tudo, e que mal podia esperar para dizer a seu pai que estava preparado para enfrentar aquela criatura dentro da cova. Logo chegou à terra dos tocadores de flauta celestiais. Quando encontrou o dono daqueles campos no pátio de sua casa, ele the disse:

- Quando cheguei aqui pela primeira vez era um covarde. Agora estou pronto para lutar e fazer o que meus antepassados fizeram, seja qual for o resultado. Tenho confiança em Allah, o compassivo.

- Que assim seja, disse o velho homem. Eu sabia que você sendo o verdadeiro filho de seu pai, que foi meu companheiro quando estudamos juntos - no tempo certo, iria enfrentar suas dificuldades. Vá e que Allah esteja com você!

Algum tempo depois, Adil chegou a seu reino e pediu imediatamente ao grão-vizir para levá-lo à cova do leão. $O$ velho rei o abraçou muito feliz e os três se dirigiram para a cavema. A espada e a adaga que o príncipe carregava brilhavam ao sol. Então, um escravo abriu a enorme porta e Adil entrou corajosamente. O leão começou a rugir, levantou-se e andou na direção do príncipe com a enorme mandibula aberta. O príncipe olhou para aquele animal sem medo, armas na mão, enquanto o rei, o vizir e o escravo ficaram em silêncio, observando. O leão deu um outro rugido, mais forte que o anterior e chegou perto dele. Então, para o espanto do príncipe, o monstro pôs-se a esfregar sua cabeça contra seus joelhos e lambeu suas botas como um cão amestrado.

- Agora você pode ver, disse o grão-vizir, que este leão é tão dócil quanto um escravo dedicado e não faz mal a ninguém. Você passou no teste por ter entrado na sua toca. A prova do seu valor está completa. Agora você é digno de ser o nosso futuro rei. Louvado seja Allah! O jovem mal podia acreditar no que tinha acontecido. Quando 
saiu dali, o leão veio junto com ele, andando a seu lado, até que o escravo o levou de volta para a cova.

Houve muita festa no palácio e no dia seguinte as comemorações se estenderam para cada casa na cidade. Seguindo a tradição, o rei distribuiu moedas de ouro e prata para o povo reunido no grande pátio sob o balcão real. Adil contou a seu pai sobre seu desejo de casar-se com a princesa Peri-zade e o rei mandou um mensageiro buscá-la.

Para Adil, o tempo que a comitiva demorou para trazer sua amada pareceu-Ihe uma eternidade. Ela chegou acompanhada de parentes e amigos, todos vestidos com as mais belas roupas de casamento. Até o fim de seus dias ele guardou na memória a visão que teve da princesa, cavalgando um cavalo branco árabe, com roupas da mais pura seda e jóias de beleza inigualável. As festividades do casamento duraram sete dias e sete noites. Assim, eles foram muito felizes e quando Adil tomou-se rei, fez uma inscrição com letras de ouro no chão de seu quarto de estudos particular que dizia:

'Nunca fuja de um leão."'

PS: Ádil, derivado do árabe, significa "justo", do verbo "ser justo". Azad, derivado do persa, significa "livre", "isento".

Peri-Zade, derivado do persa, significa "filha do guia espiritual".

(Traduzido por Regina Machado de: "Prince Adil and the Lions") in Shah, Amina - Arabian Fairy Tales, Octagon Press, London, 1987, pp. 157-167.)

Seguiu-se à leitura atenta deste conto a tarefa solicitada para que cada um, durante uma semana, representasse - desenhando, escrevendo, descrevendo através de uma história... - o seu leão. Os resultados são mostrados nas páginas seguintes. 
158

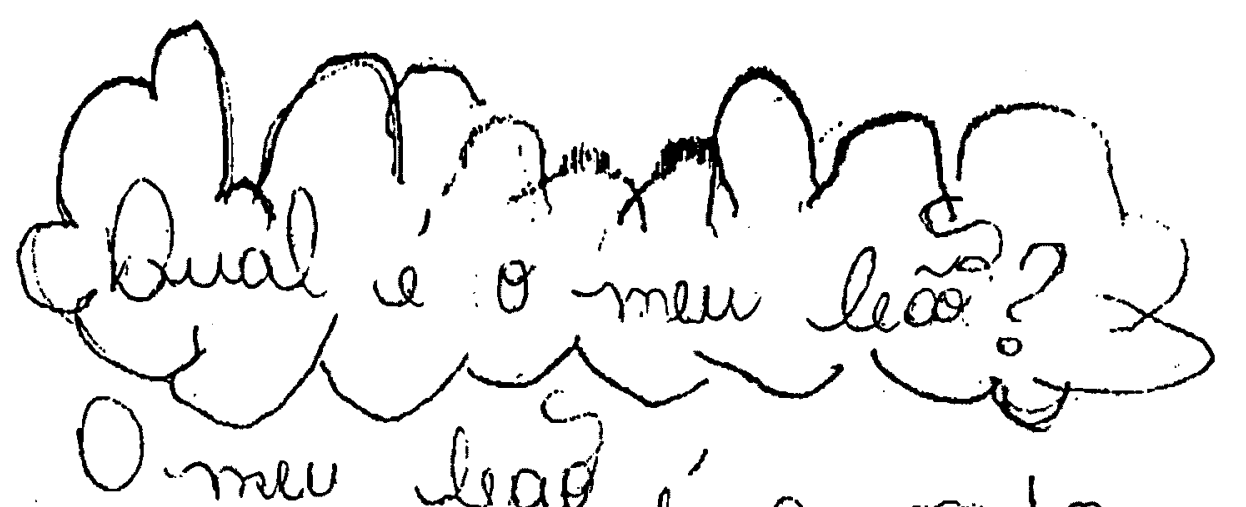

brigp e quorido en vijo uma briga e destricicao em framiliá.

Ev meu leas tarnbém, 'é quondo

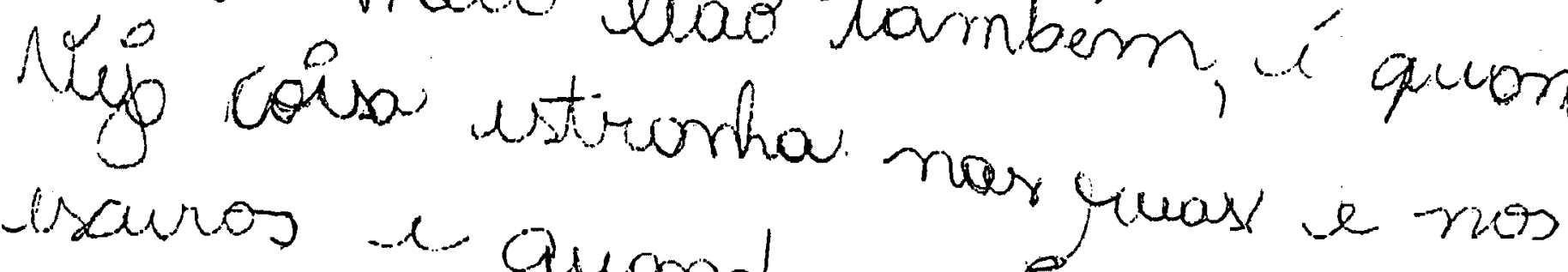
uscuros equondo velia

...na continuação a menina diz: “... e quando vejo uma coruja. As pessoas dizem que quando uma coruja olha em seus olhos é que alguém da sua familia está perto de morrer. E que nem uma borboleta, a ciência diz que quando uma para no seu ombro quer dizer que a pessoa está perto de morrer." 

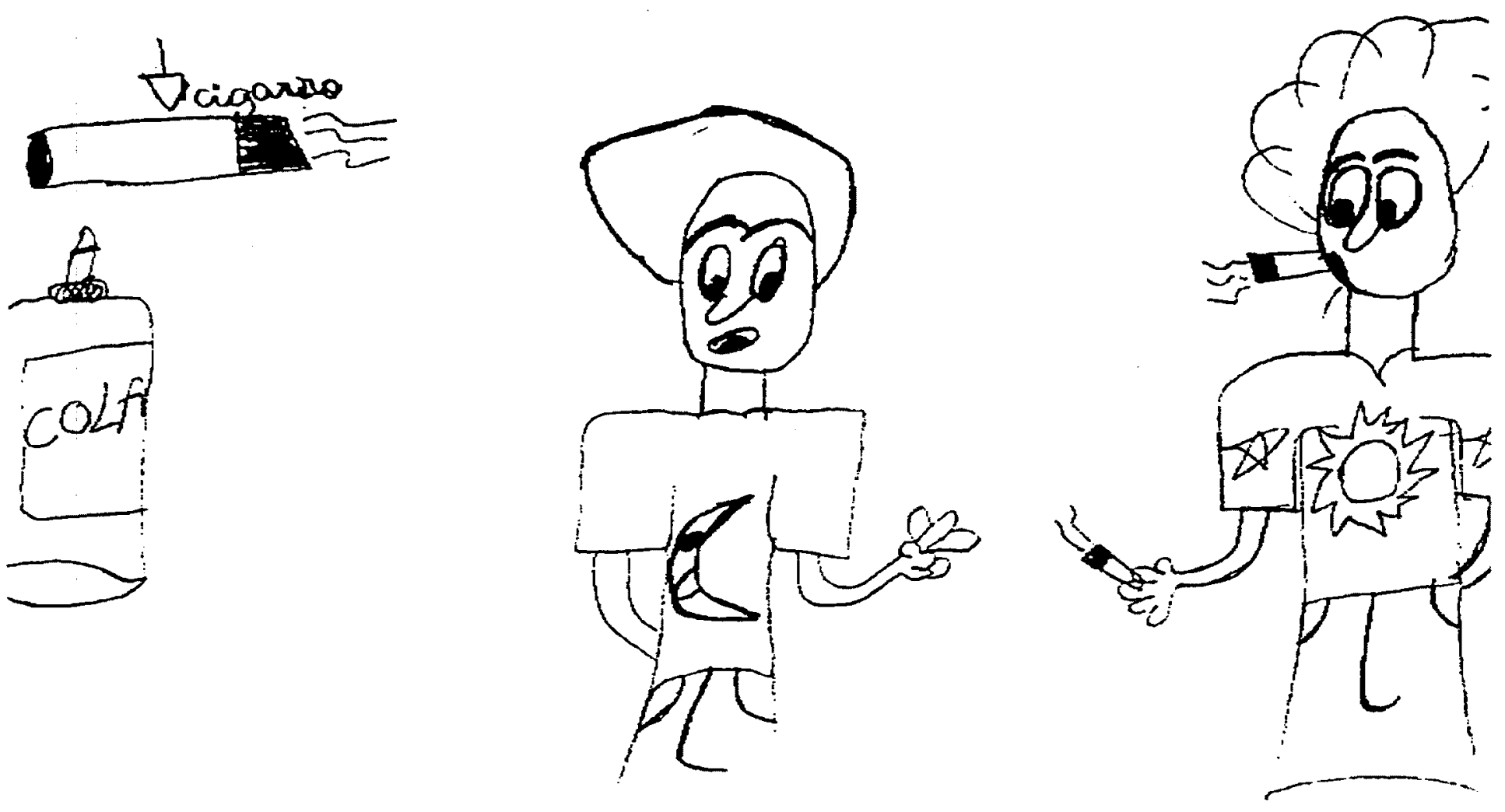

A figura acima foi desenhada por um menino.

Ao desenho abaixo, de um menino, sucede a frase: "Meu medo é uma bala perdida"

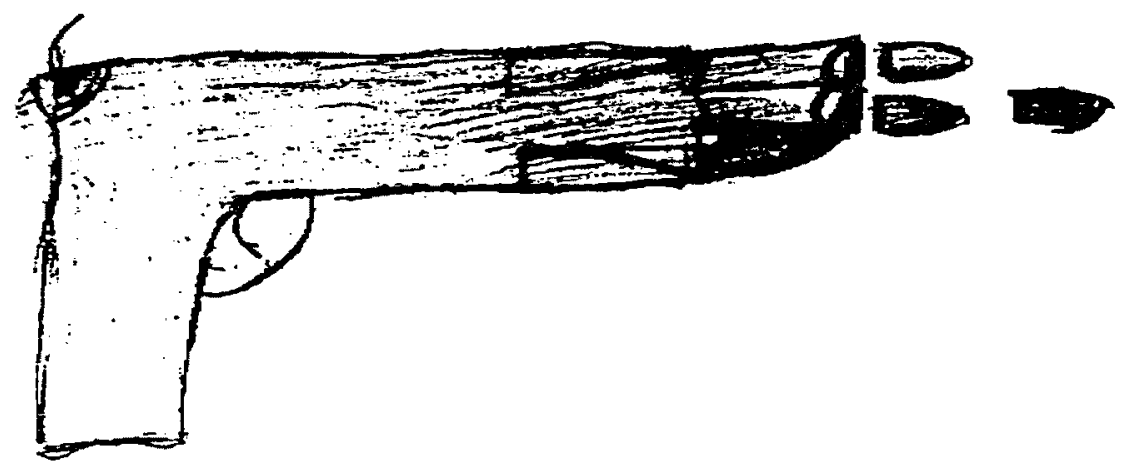


"Meu medo é altura"

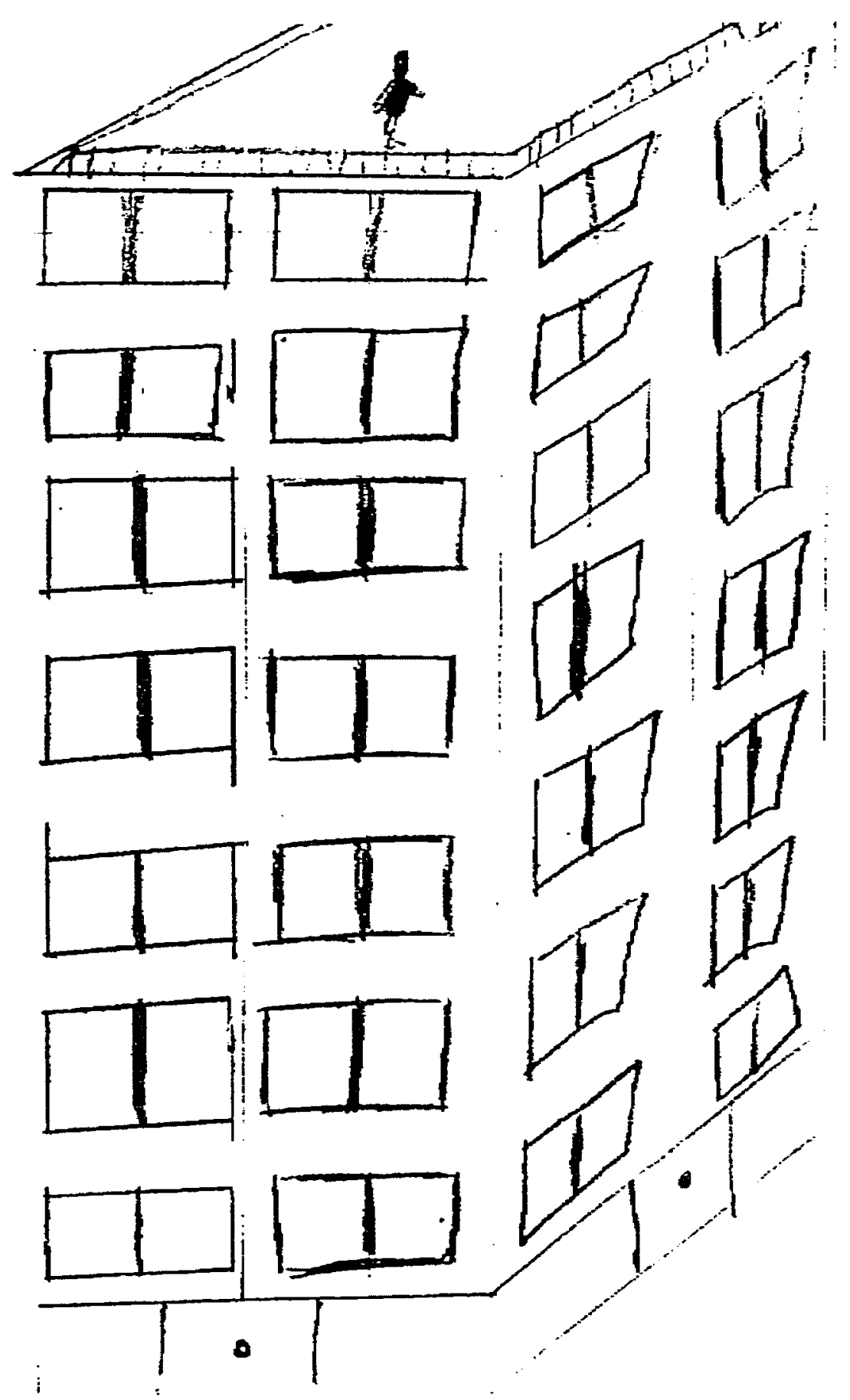


161

Uma garota escreve:

$-4$

(1) maver detafiz eque en terche é pooter intender as pessecs

mas a mintina alegie l' ter urra arrizade comber tisho com a Gisele.

(Obs.: Gisele é a coordenadora do CJ);

Um menino desenha a si mesmo (ele disse isso) com uma parede na frente e atrás da parede nuvens. Depois escreve: "Nunca tenha medo, e sim supere o medo que há em vocé."

Um menino escreve em letras enormes "ALTURA" e completa: "eu vou tentar superar isso.";

Outro menino desenha um leão com juba bem grande e escreve: "não fuja de seus problemas";

Outro ainda: "O meu medo, o meu leão é andar de barco e voar de avião. Meu medo de barco por que já vi muitas pessoas morrerem em um barco e a mesma coisa em avião. Tenho muito medo mais ainda de altura."

Uma garota escreve: "Nunca fuja de seus problemas, pois onde vocé for ele vai estar junto!" e completa: "Meu maior leão que eu tenho em minha vida é: Ir para o Iraque, Afeganistão, de ir para uma floresta, e andar de navio e, lógico, a morte é meu maior leão." 
Essas manifestaçōes, lembrando, aconteceram uma semana depois da segunda oficina sobre drogas. Os adolescentes foram reunidos nessa ocasião, nem todos estavam presentes nesse dia, o conto foi lido novamente e foi lembrada a tarefa que haviamos solicitado: "qual é o seu leão?" 0 material disponivel incluía papel e lápis e todos conversaram entre si, trocando impressões, antes de realizarem a tarefa.

Encontra-se fora do escopo deste trabalho qualquer tentativa de interpretação psicológica dos desenhos e frases elaboradas. Os motivos e situações expressos, porém, parecem manifestar temas que fazem parte do imaginário infantil - medo de ALTURA, de avião/voar, barco/água por exemplo. Por outro lado, há situações comuns à nossa época e um pouco mais próximas, sem dúvida, de adolescentes em situação de vulnerabilidade social - briga e destruição em família, uso/venda de drogas, revólver disparando balas/bala perdida - estas temperadas positivamente por um desejo/desafio de "entender as pessoas" e a enorme alegria de sentir uma grande "amizade".

Deve ser enfatizada neste ponto a amplitude atingida pela manifestação dos adolescentes acerca das oficinas sobre drogas propiciada pela tarefa encadeada ao conto de ensinamento "O Príncipe Adil e os Leões", aliada à forma aberta para sua expressão. Essa situação fica clara quando comparamos sua manifestação, em ocasião anterior, ao atender o pedido de que explicassem "o que acharam mais importante nas oficinas sobre drogas?" Tivemos, por exemplo: "que é muito bom para os alunos não usarem drogas na juventude"; "se não quer estragar a sua vida, não use drogas, sem elas você fica bem melhor"; "lá explicou o que a gente não sabia, algumas coisas a gente já sabia, é bom porque pode mudar o modo de pensar das pessoas"; "seja inocente e não desobediente"; "não use drogas por que só vai te levar para o mal caminho, como a cadeia e a morte", ... Fica evidente aqui a maneira "superegoica", severa e 
compreensivamente auto-restritiva, além de próxima de certos clichês, que os adolescentes adotaram como expressão - o que não se pode dizer que seja algo absolutamente negativo do ponto de vista de seu efeito concreto em suas vidas, tampouco pode-se dizer o contrário. De qualquer forma, a diferença de expressão, acredito, se deve, em parte, ao tipo de pergunta feita, sua expressão através da escrita, e ao não recurso às imagens propiciadas pelo conto. Mas fiquemos por aqui, uma vez que este também não é o tema principal desta tese, cumprindo unicamente uma função ilustrativa do arrazoado teórico como mencionamos antes.

Voltando para o foco central de nossa discussão, podemos dizer, talvez, que se mantemos como referência jovens no início da vida fica mais fácil vislumbrar os postulados que até aqui articulei através dos conceitos de alienação e liberdade - que mantém na escolha pessoal o eixo sobre o qual se assenta a direção que será tomada em uma vida, podendo catapultá-la num ou noutro sentido. Cabe perguntar, porém, se a força desses argumentos consegue manter-se incólume quando examinamos os testemunhos das mães dos futuros adolescentes que seguirão no Reino, quer dizer aquelas que fazem parte do "Programa de Estruturação Familiar e Geração de Renda". A elas foi solicitado que escrevessem livremente sobre sua experiência de participação no programa até aquele momento (07/10/2003), passados cinco meses de trabalho na instituição (compreendendo tanto sua capacitação profissional, quanto nossas oficinas quinzenais). Foi realizada uma reunião especial para isso, distribuiu-se papel e caneta e Gláucia (responsável pelo programa na instituição) deixou-as a sós para a tarefa. Na seqüência encontramos alguns dos documentos produzidos então: 
164

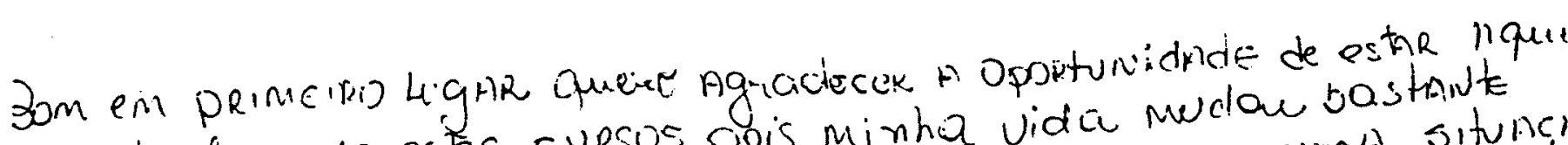
phe cente fazendo estes cursus. pois minha vida mudou bastante

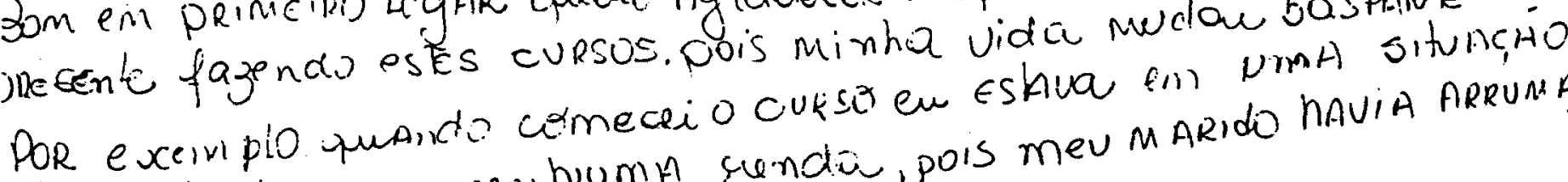
nuito dificul, sem meinutuma geendé, pois meu marido havia ARrunia 10. un bia yuASE NA naESMA é́OCH.

Eu predi muita COISA, CORRB, CASA tudo que eu tinha, frquei sens nda MAS geACAS A DEUS AOS pOUCOS estow conguistando tudo de nOUD, COm 8 meu esfor , $_{0}$ e do MEU MAR Ido, fá consegainios NOSSA CASA.

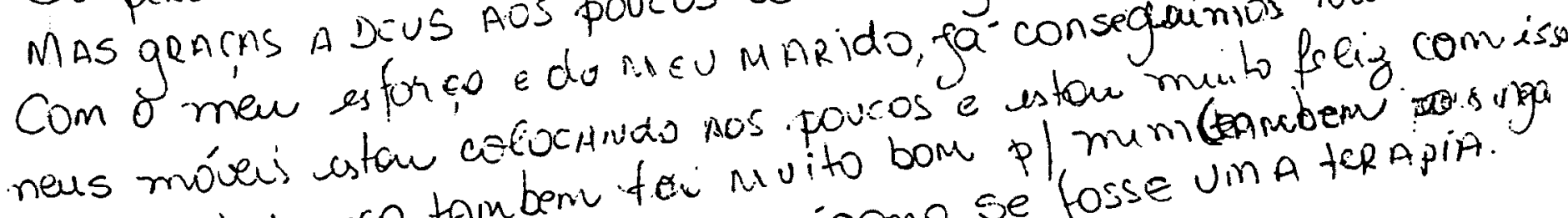

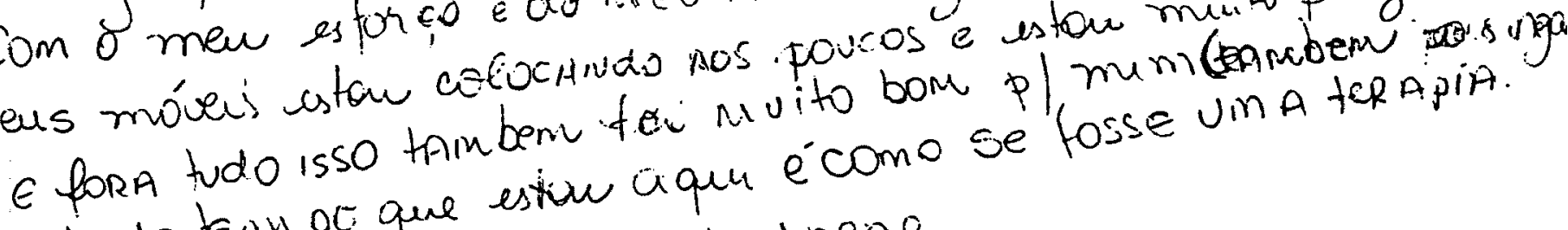
pois todo temu po que estiou aqua écomo se fosse una Bom isso e oque terito a decbarar.

$$
0=3+1,6,
$$

En face o curso de pamificação éum curoo munto bom, porque estou aprendende muito coisa que en nã. sobrio fazer.

Estou me sentindo muito bem porque confeci minta pessoas legars e me sinto uma pessoon util (E) Com o dinpreno do projeto en comsegui compra 1 frizzer usado \& parteleiras a alguns rasintames Er querno abiir um bar mas náo den certo agoro en quero envestir em outra coisa 


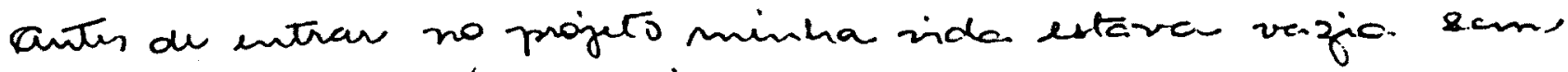
opgets de trabe. Ch $d$, desamimade. sem, runno.

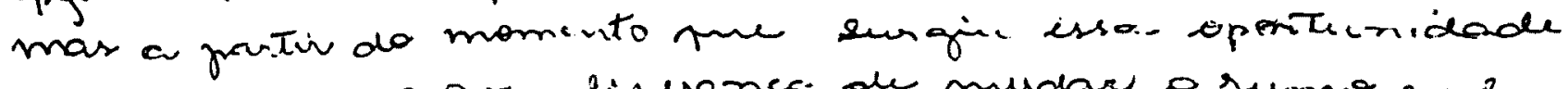
agarnei numa neva, lifpuance de mudar o rumo que estava bomounde minha, vida. ho incicio, un mies ariter

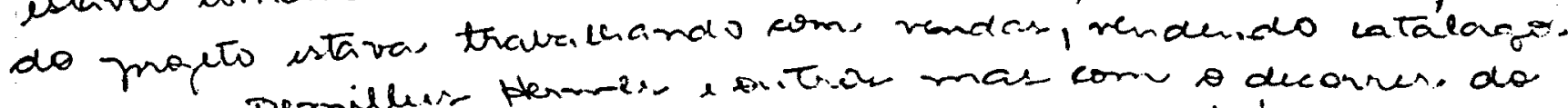

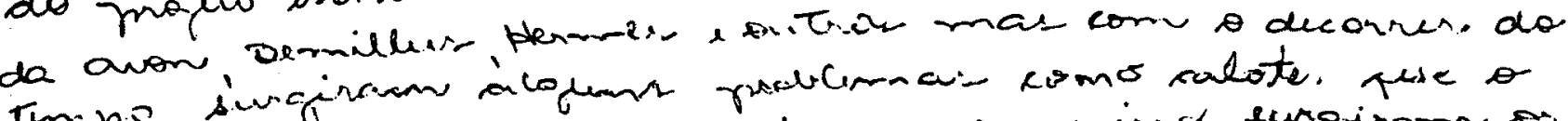

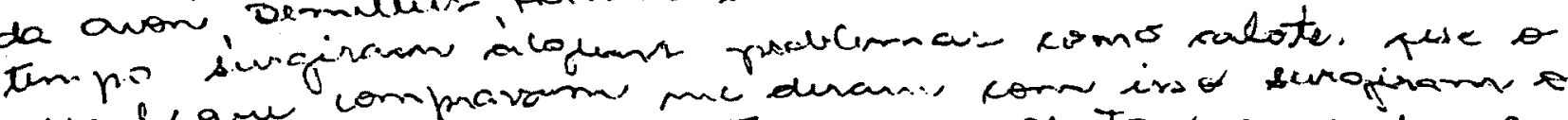

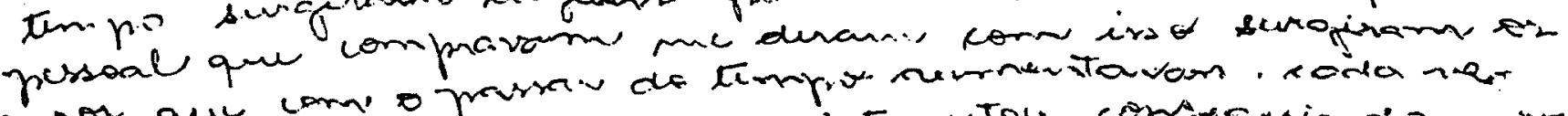

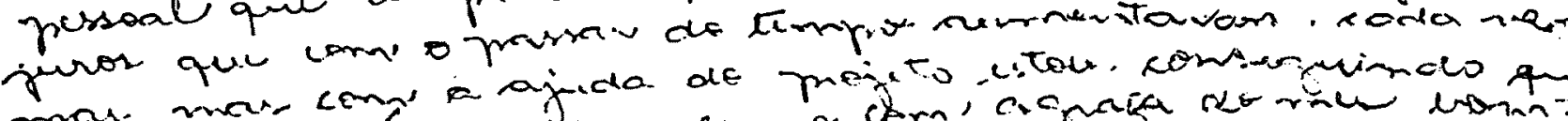

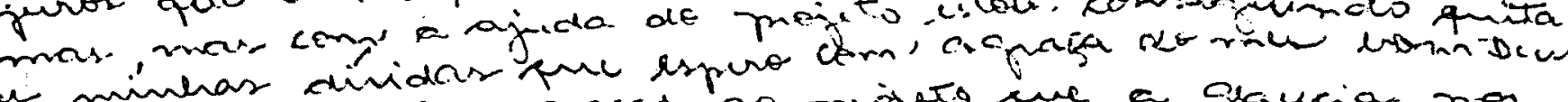

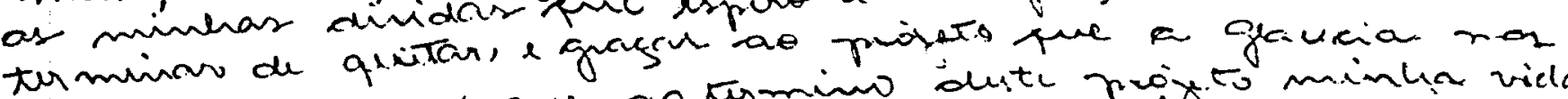

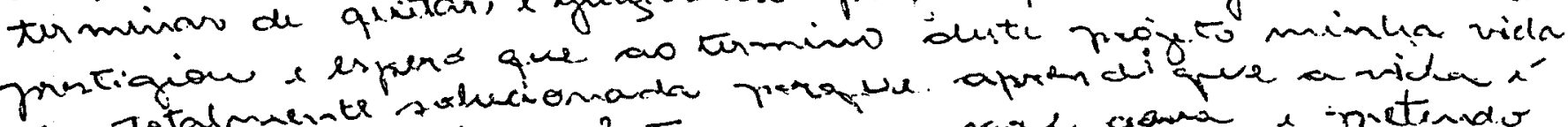

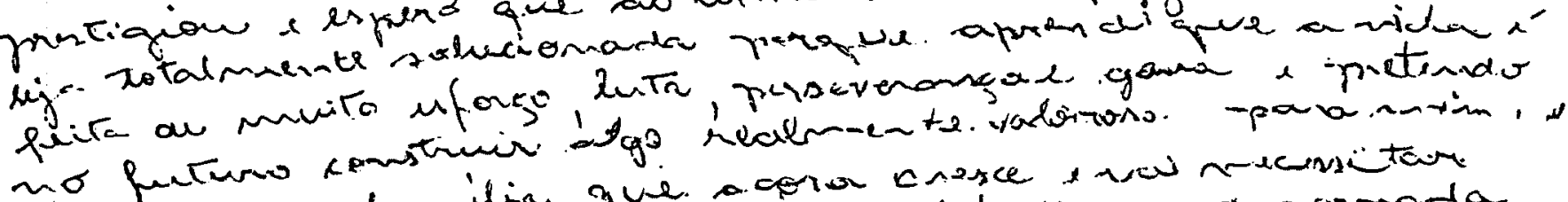

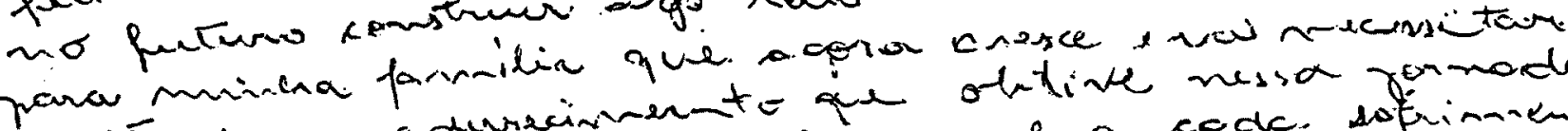

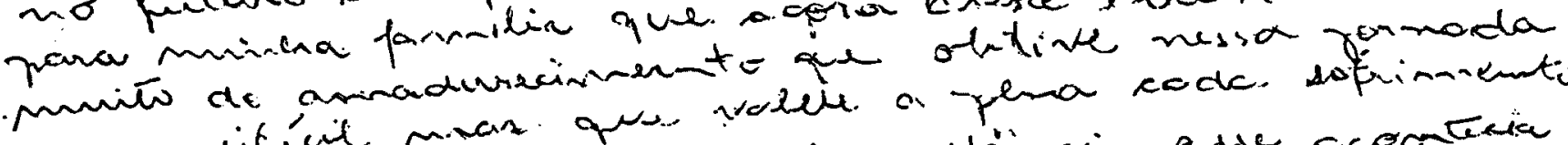

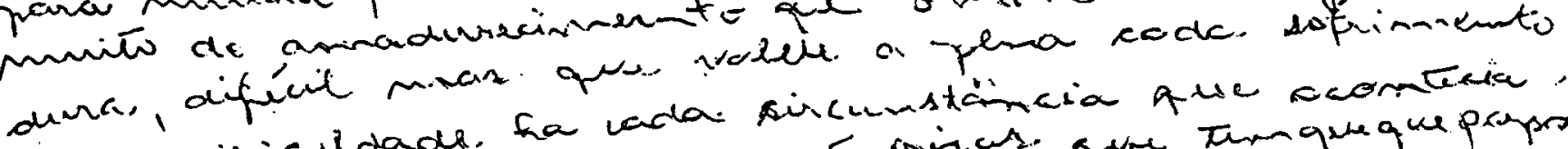

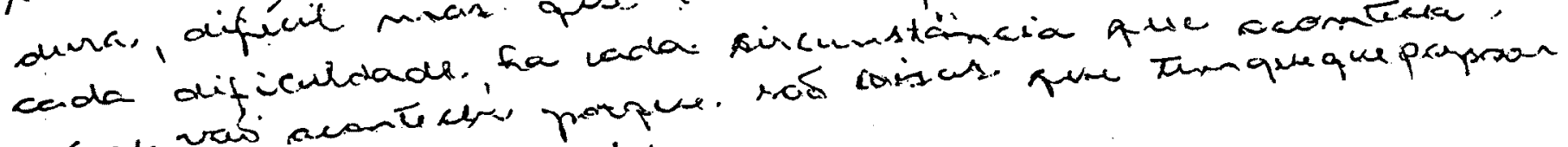
sá pacentucimantar da vida 
166

Depois que en entrei no progeto en aprendi muitas coisas comprei Batrdena frize forma de lo outras corras anto de entra no-progcto en me sentic muito nazia de serta forma me encher um napio que avia an mim agora. en me rinto macis contente alegre face ciasas para vendes bolos, hucien. vendo toalla bordada caminho de mera agora näo terho tempo pava tristera 
Berm, ear grounticiminits de estar participandro deats

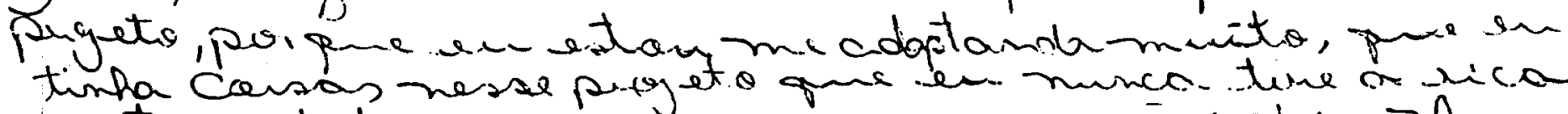

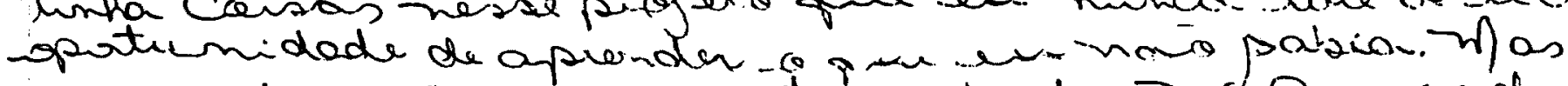
en egrode yo a essa ganturidode. no Cameis desse

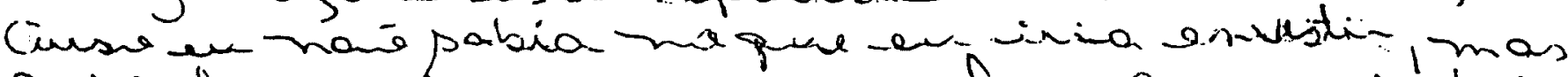

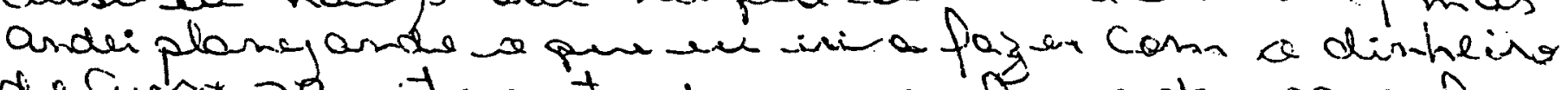

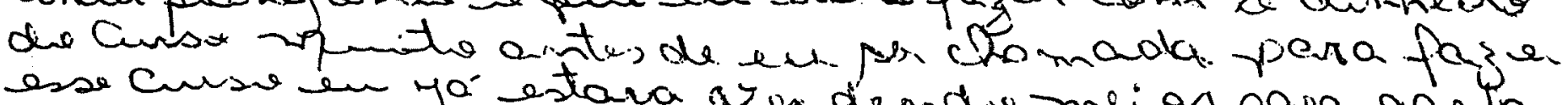
esse Curse en yo estava veridende meias perra garntar

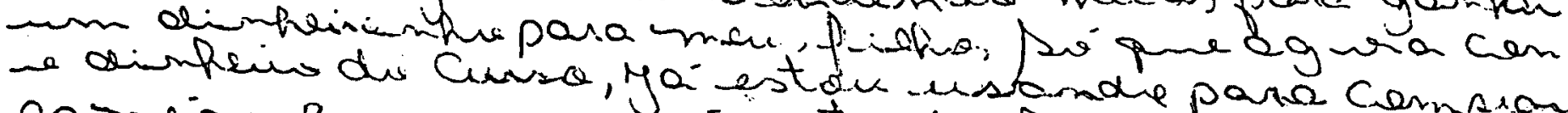

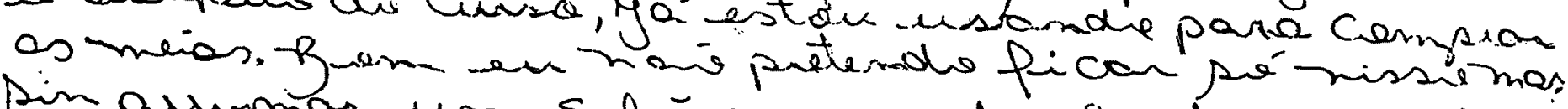

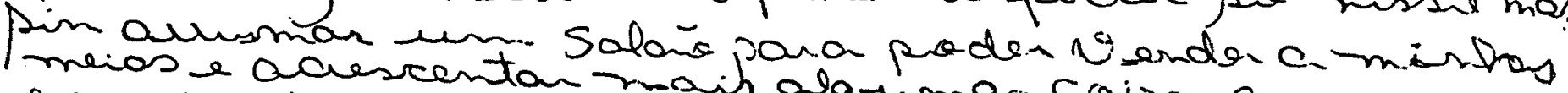

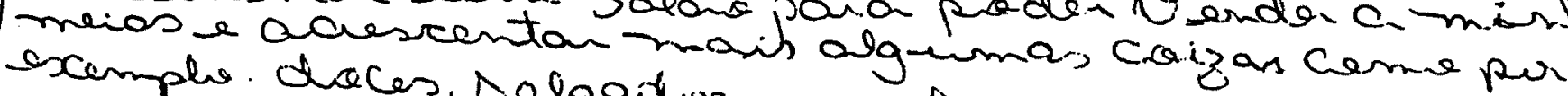

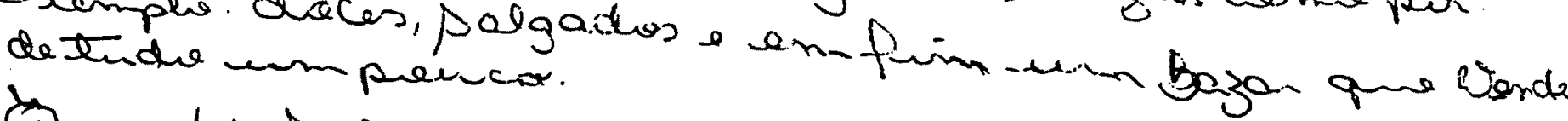
Esse dienheriogere Cursa a mon meino de gente Gescer mais respemsab lidaderte esta envestid o também ter

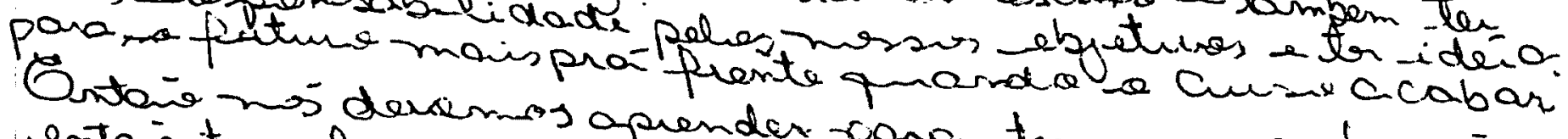

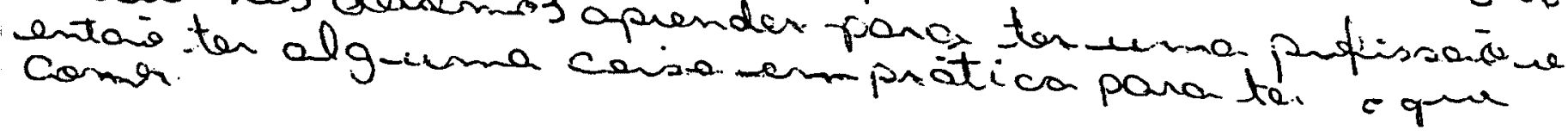


168

Depais de obril mudon o mintuo vide man poumeiro pogenero fipai une mararible

Comprei lifanterices Para vender, Compreimen uniform do panpicacéce $E$ vendi eastent graces adens

Depais comprai langeris, presilles, lifanterias a meics t vendi

Agora entrin no burdado a oprendi a border pazer vagonite $\sum$ estan amando:

mes polta muitas coises.

fo dui o entrode en unia máguima de castura panc operpiciacer

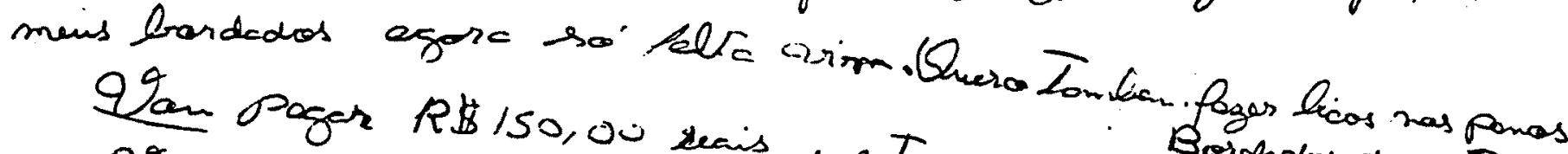

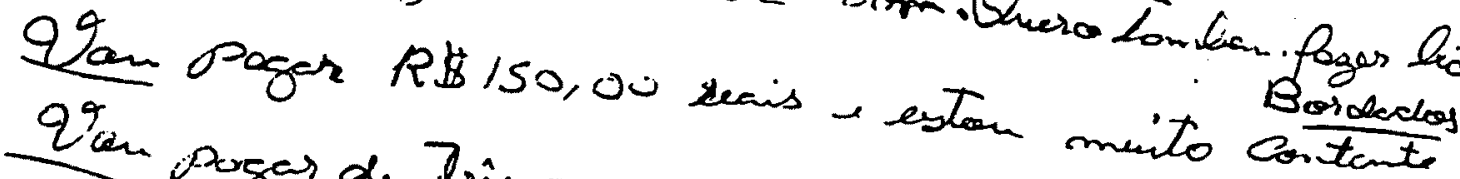

Q⿻ici purgar de tries axyes

Quera canpror mais linlas, mais panas de bardor conno

- Itamine a vogonite, cortcobar an lesouros mais linkas, mais

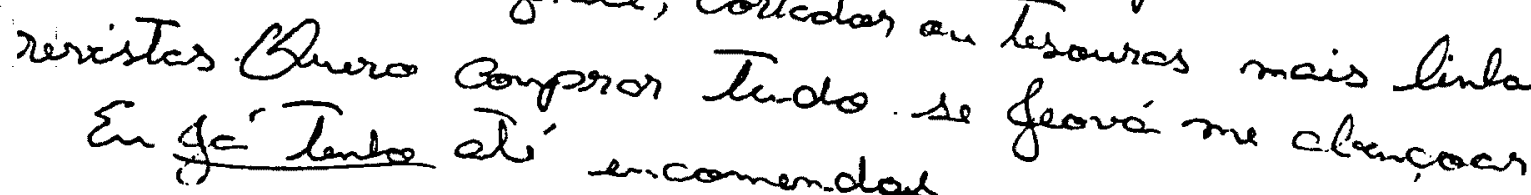
En gét tembe at'́ encomemdoss

Cperndi algunes caisas coma fazer poo balos etc.

mais o que amei fai as lordcolos. 
169

Banr antes que en entran Neste profeto an Traballhavio. en Cusa de farmía

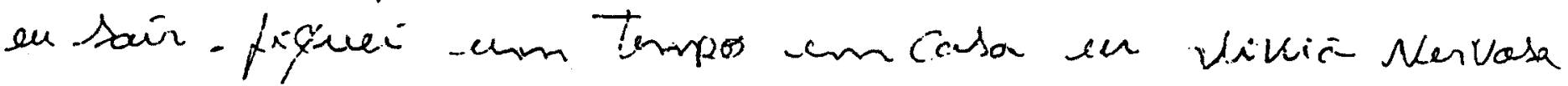

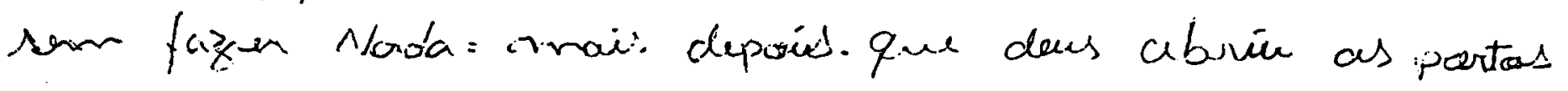

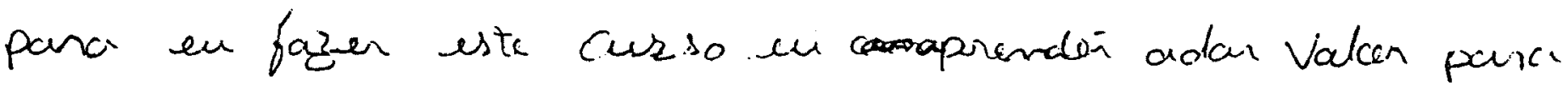

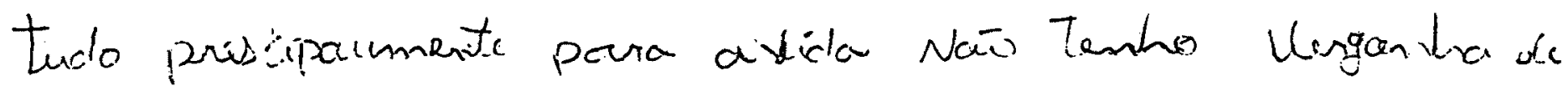
sair vendere Tudo que en apuendei en yecto de tilender o leite Condensado pana Verder.

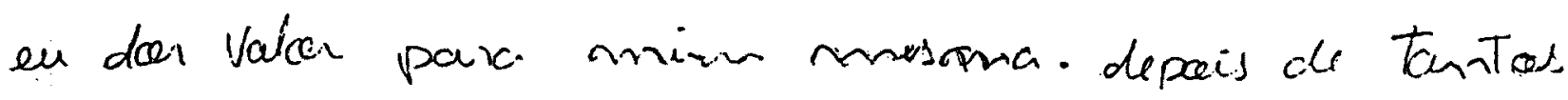

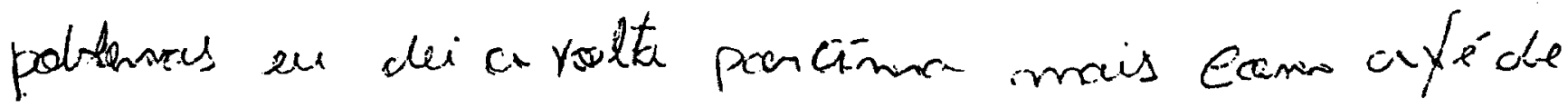
deur en vou dan avalta par eirna pan que en kutro

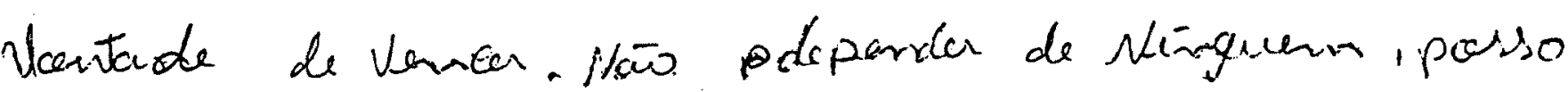

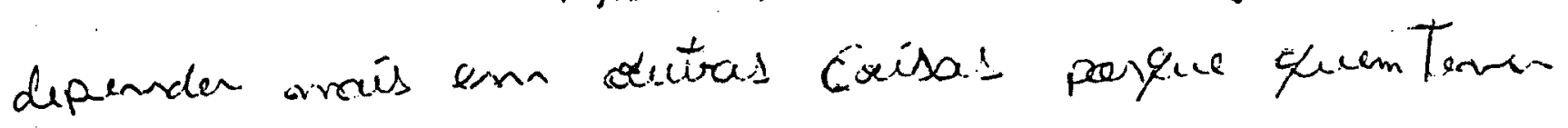
fillo depende de todo mundo mais aste cicso tex

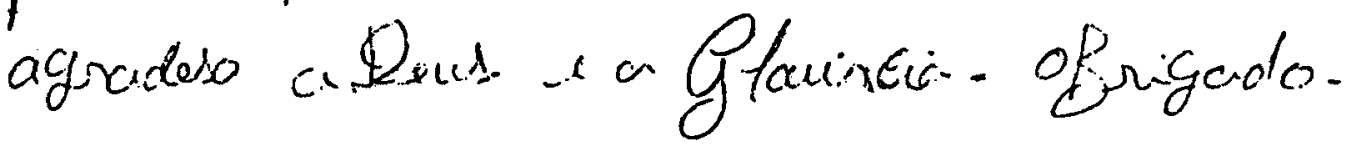


De novo, não se trata de interpretar psicologicamente nem tampouco perfazer uma análise de discurso em busca desta ou daquela representação. Interessa somente colorir um pouco e emprestar realidade ao meu próprio discurso intelectual, proposição que, antes de continuarmos, permite alinhavar algumas das reflexōes metodológicas desenvolvidas ao longo do trabalho, tarefa importante pois nos aproxima daquela "outra cena" como dizia Freud, que por sua vez tem proximidade com a verdade. Desde Bacon R. que postulava a existência de

"dois modos para adquirir o conhecimento, um através do raciocínio e outro através da experiência. O raciocinio atinge uma conclusão e nos obriga a concedê-la, mas não provoca certeza nem elimina dúvidas, de maneira a permitir à mente repousar na verdade, o que somente pode ser proporcionado pela experiência". (id ibid)

Passando por Merleau-Ponty M. ao distinguir a síntese perceptiva da sintese intelectual referindo-se ao "simbolismo de nossa atividade intelectual corrente sustentada pelos signos que anunciam as coisas, mas que se contentam em anunciá-los" (op cit, p. 26)

Levando em conta também a compreensão de Eco U., manifestada através de seu personagem franciscano, acerca da prevalência da coisa aludida por sobre o signo que a anunciava que o leva a propor o que chama de intuição do Singular como sendo o conhecimento pleno,

"De modo que eu, há uma hora atrás, estava pronto a esperar qualquer cavalo, e não pela vastidão do meu intelecto, porém pela exigüidade da minha intuição." (id ibid)

Terminando com a refinada percepção de Pessoa ao assumir que "entre mim e ver há um grande sono",

"Uma névoa de outono o ar raro vela,/Cores de meia-cor pairam no céu./O que indistintamente se revela,/Árvores, casas, montes, nada é meu. 
Sim, vejo-o, e pela vista sou seu dono,/Sim sinto-o eu pelo coração, o como./Mas entre mim e ver há um grande sono./De sentir é só a janela que eu assomo.

Amanhã, se estiver um dia igual,/Mas se for outro, porque é amanhã,/Terei outra verdade, universal,/E será como esta." (Pessoa F. op cit, p.561)

Voltando a nossas considerações em torno das manifestações das mães que fazem parte do programa de estruturação familiar e geração de renda do Reino da Garotada, queremos contrastá-las com: 1) algumas de suas motivações - vontade de vencer/não fracassar, ter comida na mesa para os filhos, contato com o grupo/novas amizades, engeção de ânimo com o curso, 'agora não tenho tempo para tristeza', 'todo o tempo que eu estou aqui é como se fosse uma terapia' ; 2) seu "princípio de realidade" - 'não quero depender de ninguém, posso depender mais em outras coisas porque quem tem filho depende de todo mundo', 'paguei 6 parcelas de imposto atrasadas de 95, 96, 97, com juros', 'esse dinheiro do curso é um meio da gente crescer na vida,..., e também ter mais responsabilidade pelos nossos objetivos e ter idéia para no futuro mais pra frente quando o curso acabar; 3) alguns de seus projetos - 'espero que ao final deste projeto minha vida esteja totalmente solucionada pois aprendi que a vida é feita de muito esforço, luta, perseverança e garra', 'queria abrir um bar mas não deu certo agora quero investir em outra coisa', 'estou revendendo meus salgados, comprei um freezer, uma barraca de pastel, não que eu esteja ganhando rios de dinheiro, mas o suficiente para sobreviver eu e meus quatro filhos'; e 4) quase nenhum desespero - 'antes de entrar no projeto eu me sentia muito vazia, de certa forma preencheu um vazio que havia em mim', 'quando comecei o curso estava em uma situação muito dificil, sem nenhuma renda,..., perdi muita coisa, carro, casa tudo o que eu tinha,..., mas graças a Deus estou conquistando tudo de novo. Com o meu esforço e o do meu 
marido...', já pensei sim em desistir pois as coisas estavam muito dificeis. Ai eu pensei se as coisas estão melhorando, porquê parar de tentar, pois tudo na vida é com luta, então não posso parar, pois meus filhos dependem exclusivamente de mim para tudo', 'consegui parcelar minha luz que já estava cortada há três anos', 'com o meu primeiro pagamento(do programa) comprei um cavalo e uma carroça, tudo estava indo ótimo, nós estávamos pagando o cavalo quando roubaram o meu cavalo. Fiquei desesperada, mas não desisti, terminei de pagar o dono do cavalo e devolvi a carroça. Fiquei muito revoltada porque era o meu ganha pão, que sustentava a casa, e no mês de maio comprei uma geladeira...; 'fora os meus problemas, até que eu acho que estou progredindo'...

São muitas as histórias, cadenciadas por obstáculos não raro inexplicáveis de um ponto de vista humano rasteiro, tanto que podemos nos sentir tentados a permanecer num sentido, mas entre duas poéticas:

"Dorme que a vida é nada!/Dorme que tudo é vãol/ Se alguém achou a estrada,/Achou-a em confusão,/Com a alma enganada.

Não há lugar nem dia/Para quem quer achar,Nem paz nem alegria/Para quem, por amar, $/ E m$ quem ama confia.

Melhor entre onde os ramos/Tecem dosséis sem ser/Ficar como ficamos,/Sem pensar nem querer, Dando o que nunca damos."

("FERNANDO PESSOA / OBRA POÉTICA (10-10-1933))

ou então:

"Todos os meus próprios momentos passados pode ser que existam algures, $/ \mathrm{Na}$ ilusão do espaço e do tempo, $\mathrm{Na}$ falsidade do decorrer.

Mas o que eu não fui, o que eu não fiz, o que nem sequer sonhei;/O que só agora vejo que deveria ter feito,/O que só agora claramente vejo que deveria ter sido - Isso é que é morto para além de todos os Deuses, / Isso - e foi afinal o melhor de mim é que nem os Deuses fazem viver. .. 
Se em certa altura/Tivesse voltado para a esquerda em vez de para a direita;/Se em certo momento/Tivesse dito sim em vez de não, ou não em vez de sim;/Se em certa conversa/Tivesse tido as frases que só agora, no meio-sono, elaboro -/Se tudo isso tivesse sido assim./Seria outro hoje, e talvez o universo inteiro/Seria insensivelmente levado a ser outro também.

Mas não virei para o lado irreparavelmente perdido,/Não virei nem pensei em virar, e só agora o percebo;/Mas não disse não ou não disse sim, e só agora vejo o que não disse;/Mas as frases que faltou dizer nesse momento surgem-me todas,/Claras, inevitáveis, naturais, /A conversa fechada concludentemente,/A matéria toda resolvida.../Mas só agora o que nunca foi, nem será para trás, me dói."

("FERNANDO PESSOA / OBRA POÉTICA (10-10-1983))

Há uma reconciliação possivel, porém, desses dois momentos do ser, configurando como que o resultado de um encaminhamento dialético. Encontramo-la no 'Julian and Maddalo' de Shelley:

\section{“Observa}

Esta adorável criança, contente, inocente e livre

Ela precisa de muito poucos cuidados

Para passar um tempo bem-aventurado

Enquanto nós, a tais pensamentos doentios,

Como os que vieram a ti na última noite, vivemos subjugados

É por nossa vontade que nos acorrentamos assim à doença [consentida -

Podemos ser diferentes - podemos ser tudo

O que sonhamos, felizes, elevados, majestosos.

Onde está o amor, a beleza e o amor que procuramos,

Senão em nossa mente? É se não fôssemos fracos,

Seriamos menores na atitude do que no desejo? ${ }^{216}$

${ }^{216}$ Citado por Sirdar I. Ali Shah, in Principios gerais do sufismo e outros textos, SP, Attar Editorial, 1999, p. $73 / 74$. 
Essas proposições, é certo, nos afastam do que pode ser chamado de homem médio, entendido como representante do lugar comum das condiçōes de vida e pensamento que o rodeiam, um mero títere do seu entorno, por nāo perceber a que ponto permanece sendo manipulado por outrem, por suas "próprias" idéias. Ao mesmo tempo, tudo o que foi postulado até aqui nos aproxima, nós outros promotores da saúde, desse mesmo ser humano mediano, na medida em que ele faça prova de um devotamento e de uma disciplina acima da média vis-à-vis sua intenção de progresso em seu caminho na vida, apoiando-se em seu crescente julgamento interior a que aludimos antes, fruto do trabalho sobre si mesmo, este originado por uma escolha realizada não na clareza de uma consciência nua, mas entremeada pelas coisas do mundo, de tal modo que se verifique mais uma vez a indicação contida no ditado que afirma que "o homem deve estar no mundo, mas não ser do mundo". 


\section{CONCLUSÕES}

Dadas as caracteristicas próprias à adolescência, que implicam antes de tudo aceitar que não é fácil ser adolescente; dada a situação de vulnerabilidade social, e existencial, que se acrescenta a essa condição, conferindo-Ihe um enquadramento especificamente difícil que acomete grande parte dos adolescentes brasileiros. Dadas as possibilidades sempre presentes para cada adolescente de eleger certa substância psicoativa como alavanca maior para vir a situar-se no mundo - quando na verdade ela não passaria de muleta. Dadas as difíceis condições concretas nas quais se desenvolvem os programas de saúde pública no Brasil destinados a esse público, onde convivem boas idéias e intençōes juntamente com orçamentos pífios administrados por estruturas lentas vis-à-vis o desafio que tem pela frente. Dada a penetração cada vez mais facilitada das drogas junto aos adolescentes e suas familias, tendencialmente cada vez mais cedo e em faixas cada vez mais amplas, como o demonstram as estatisticas. Dada a condição de miséria econômica, social, cultural e, em certa medida, da dignidade pessoal mesmo, a que largos estratos da população continuam se submetendo e sendo submetidos - que acarreta direta ou indiretamente a constituição de familias que retransmitem, muitas vezes sem qualquer polimento, essa condição aos filhos, ao observarem seus sonhos, por vezes legitimamente alicerçados, por vezes embalados mediaticamente, alcançarem pouco mais do que o estágio da fundação. Dado o grau de desagregação individual, familiar e social, causado pelo consumo abusivo ou de dependência em relação às substâncias psicoativas, legais e ilegais.

Mas também, dada a percepção de que, contrariamente a certos préjulgamentos, muitos adolescentes, a despeito de sua condição social e econômica, quando sentem poder exercer a confiança, não tem, como se 
poderia dizer, o diabo no corpo. São pacientes, amorosos, românticos e passiveis, até, de praticar a prudência. Aliás, é bom lembrar que:

"Confiança, como diz Guimaräes Rosa, o senhor sabe, não depende de feitos perfeitos: ela é o quentinho que rodeia a pessoa".. ${ }^{217}$

Por todas essas razões, não há como postular para as intervenções junto a adolescentes e suas famílias, qualquer coisa menos do que a educação para a saúde tendo como referência constante sua formação a um nivel profundo, sua Paidéia como tratamos desde o início desta tese. Há tanta coisa em jogo que não há como nos permitirmos nos confundir entre o que são meios e o que devem ser os fins reais a serem perseguidos, em cada adolescente, durante uma intervenção visando a promoção de sua saúde - sua conexão consigo mesmo, a percepção da "ciência da unidade" como chamava Sócrates, seu "ser essencial" como chamamos antes. Única fonte segura para que se propicie a edificação de uma certeza constante, em cada indivíduo inserido que está em sua comunidade de referência, quanto ao desenvolvimento possível das capacidades que lhes são próprias situação comumente chamada de auto-estima.

O fundamento dessa atitude tem que ser encontrado numa perspectiva de liberdade que se faz real em primeiro lugar por compreender que o mais comum dos sujeitos "estende-se muito além daquilo que o indivíduo sente 'subjetivamente', em termos exatos essa extensão depende da verdade que ele pode alcançar ${ }^{n 218}$. Em segundo lugar, por não abandonar nunca, sem elidir os enormes obstáculos a serem transpostos, a direção escolhida, sua intenção.

\footnotetext{
${ }^{217}$ Citado por Lidia Rosenberg Aratangy, in DESAFIOS DA CONVIVÊNCIA,Ed. Gente, São Paulo, 1996, que acrescenta: "Confiança não depende de decisão racional, mas da sensação interna de acolhimento que o outro nos provoca."

${ }^{218}$ Lacan, J. - Écrits, "Fonction et champ de la parole et du langage", Paris, Seuil, 1966, p. 265
} 
O nome dessa atitude é amor, sempre na perspectiva socrática de sinceridade ao tecer suas considerações a respeito do Amor, desgarrado da posicionamento elogioso e idílico, mas também insincero, daqueles que o precederam n'O Banquete, pois que não encontram suporte na realidade.

Realidade essa que nos distancia do sentido romântico de realização amorosa fundada no imaginário autonomizado, como aludiam Dolto $F$. e Castoriadis C., cada um a seu modo, de um sujeito alienado a esse tipo de discurso, de um sujeito que tenderá a permanecer alienado.

Realidade essa que nos aproxima de um amor perfeito entendido "não como um fruto da natureza mas sim da graça, quer dizer (fruto) de um acordo intersubjetivo que impõe sua harmonia por sobre a natureza destruida que lhe dá suporte. ${ }^{\text {219 }}$ 


\section{BIBLIOGRAFIA}

ADORNO RCF. Capacitação solidária: um olhar sobre os jovens e sua vulnerabilidade social. São Paulo: AAPCS, 2001.

AL-GHAZZALI. La alquimia de la felicidad. Madrid: Sufi, 1993.

ARATANGY LR. Doces venenos. São Paulo: Olho d'Água, 1991.

ARISTÓTELES: Poética. São Paulo: Ars Poética, 1993.

ARISTÓTELES. Metafísica. São Paulo: Edições Loyola, 2001.

ASTI V. Metodologia da pesquisa cientifica. São Paulo: Globo, 1979.

BACON R. Opus Maius. On experimental science (1268), Medieval Sourcebook, www.fordham.edu/halsall/source/bacon2.html.

BASSIT AZ. Prevenção ao uso de drogas. In: GUERRA A. (ORG.), BASSIT AZ. Manual: avaliação de programas de prevenção de drogas. São Paulo: Artcolor, 1995.

BETTELHEIM B. Uma vida para seu filho. Rio de Janeiro: Campus, 1988.

BETTELHEIM B. A Psicanálise dos contos de fada. Rio de Janeiro: Paz e Terra, 1995. responsáveis. 
BINSWANGER L. De la phenomenologie. Introduction à l'analyse existencielle, Paris: Minuit, 1971

BÓGUS CM, WESTPHAL MF. A formação politica e o fortalecimento da participação popular em saúde: o caso dos Cursos de Formação Política de Conselheiros de Saúde do Movimento de Saúde da Zona Leste de São Paulo. São Paulo, 1997. [Tese de Doutorado - Faculdade de Saúde Pública da USP] Parte III (pp. 67-196).

BOVERO M. Contra o govemo dos piores: uma gramática da democracia. Rio de Janeiro: Ed. Campus, 2002.

BRASIL. Carta de Ottawa. Ministério da Saúde: Projeto Promoção de Saúde. Brasilia, 2001.

BRASIL. Declaração de Jacarta. Ministério da Saúde: Projeto Promoção de Saúde. Brasilia, 2001.

BUCHER R. Drogas e drogadição no Brasil. Porto Alegre: Artes Médicas, 1992.

BUKSTEIN OG. Adolescent substance abuse - Assessment, prevention and treatment. New York: Wiley-Interscience Publication, 1995.

CARLINI-COTRIM BH. O Consumo de solventes e outras drogas em crianças e adolescentes de baixa renda na Grande São Paulo. Parte II: meninos de rua e menores internados. Revista ABP-APAL 1976; 9(2):69-77.

CARLINI-COTRIM BH. Dados sobre o consumo de drogas por adolescentes no Brasil. Revista ABP-APAL 1987; 9(3):99-102. 
CARLINI-COTRIM BH, CARLINI EA. O Consumo de solventes e outras drogas em crianças e adolescentes de baixa renda na cidade de São Paulo. Parte I: estudantes de primeiro e segundo graus da rede estadual. Revista ABP-APAL 1987; 9(2):49-58.

CASTORIADIS C. L'Instituition Imaginaire de la Societé. Paris: Seuil, 1975.

COSTA JF. Psicanálise da sociedade contemporânea. Rio de Janeiro: Zahar, 1979.

DIAS SMF. Avaliação dos projetos de educação ambiental voltados para o gerencialmente dos resíduos sólidos urbanos. São Paulo, Tese de Doutorado, FSP/USP, 2003.

DOLTO F. A Causa dos Adolescentes. Rio de Janeiro: Nova Fronteira, 1990.

ECO U. O nome da rosa. Rio de Janeiro: Nova Fronteira, 1983.

ENTRALGO PL. La relación médico-enfermo. Madrid: Alianza Editorial, 1983.

FÉRRÉOL G. Les contextes d'usages du cannabis dans les cités. In Adolescence et Toxicomanie. Paris: Armand Colin, 1999.

FREUD S. Dinâmica da transferência (1912). Rio de Janeiro: Imago, 1969.

FREUD S. Esquema del psicoanálisis. Madrid: Alianza Editorial, 1981.

FREUD S. Malaise dans la Civilisation. Tradução: Jean Hyppolite. Paris: PUF, 1979.

FREUD S. Metapsychologie. Paris: Gallimard, 1978. 
FREUD S. Notas psicanaliticas sobre um relato autobiográfico de um caso de paranóia (1911). Rio de Janeiro: Imago, Vol. 12, 1969.

FREUD S. Novas recomendações sobre a técnica da psicanálise III (1915). Rio de Janeiro: Imago, Vol. 12, 1969.

FREUD S. La Cuestón Del Análisis Profano: Madrid: Alianza Editorial, 1981.

FREUD S. Recomendações aos médicos que exercem a psicanálise (1912). Rio de Janeiro: Imago, 1969.

FROMM E. O Medo à liberdade. Rio de Janeiro: Zahar, 1965.

GALDUROZZ JC. I Levantamento Domiciliar Nacional sobre o Uso de Drogas, UNIFESP, CEBRID, 1999.

GALDURÓZ JC., Noto A \& Carlini E. IV Levantamento sobre o Uso de Drogas entre Estudantes de $1^{\circ} \mathrm{e} 2^{\circ}$ Graus em 10 Capitais Brasileiras 1997 , SP, UNIFESP, EPM/CEBRID.

HABERMAS J. La Technique et la Science comme "Idéologie". Paris: Gallimard, 1996.

HABERMAS J. A nova intransparência: a crise do estado de bem estar social e o esgotamento das energias utópicas. São Paulo, Novos Estudos CEBRAP, (18): 103-114,1987.

HEGEL GWF. La phenomenologie de l'esprit. Tradução: Jean Hyppolite. Paris: Aubier, 1975.

HEMPEL, C.G A filosofia da ciência. Rio de Janeiro: Zahar, 1974. 
HORKHEIMER M. Eclipse de la raison. Paris: Payot, 1974.

HUSSERL E. La philosophie comme science rigoureuse. In: SCHÉRER, R. Husserl, la philosophie et ses développements. (La Philosophie, $3^{\circ}$ tomo) Paris: Hachette, 1979.

HUSSERL E. Meditações cartesianas. Tradução: Maria Gorete Lopes e Souza,'Porto, RES Editora. 1980.

HUXLEY A. A Filosofia Perene. Rio de Janeiro, Civilização Brasileira, 1971.

JAEGER W. Paidéia: A formação do homem grego. São Paulo: Martins Fontes, 1989.

JAMOULLE P. Strategies d'intervention et space relationnel: exemple du Haimaut Belge. In: FERRÉOL $G$ et al. Adolescence et toxicomanie. Paris: Armand Colin, 1999.

KANDEL DB, YAMAGUCHI K, CHEN K. Stages of progression in drug involvement from adolescence to adulthood: further evidence for the gateway theory. Joumal of Studies on Alcohol, 1992; (53): 447-457.

KANDEL DB, YAMAGUCHI K. From beer to crack: developmental patterns of drug involvement. American Joumal of Public Health, 1993; 83(6): 851-5.

KANT E. Crltica da razão pura. Rio de Janeiro, Tecnoprint, 1965.

KHUSRU A. O jardim e a primavera. São Paulo: Attar Editorial, 1993.

LACAN J. L'instance de la lettre dans l'inconscient. Écrits, Paris: Seuil, 1966. 
LACAN J. Fonction et champ de la parole et du langage. Écrits, Paris: Seuil, 1966.

LACAN J. Remarque sur le rapport de Daniel Lagache. Écrits, Paris: Seuil, 1966.

LACAN J. Situation de la psychanalyse en 56'. Écrits, Paris: Seuil, 1966.

LAING RD, ESTERSON A. L'equilibre mental, la folie et la famille. Paris: Maspero, 1975.

LAING RD. O óbvio. in Dialética da Libertação, Rio de Janeiro: Zahar, 1985.

LAING RD. Self and others. Londres: Pelikan Books, 1986.

LEFEVRE F. O processo de constituição do sujeito, da sua Saúde e de sua Doença. São Paulo; 1995. [Tese de Livre-Docência - Faculdade de Saúde Pública da USP].

LEFORT R. Os mestres de Gurdjieff. Rio de Janeiro: Dervish, 1983.

LEVINAS E. En découvrant l'existence avec Husserl et Heidegger. Paris: J. Vrin, 1974.

LUKÁCS G. Existencialisme ou marxisme. Paris: Nagel, 1961.

LYOTARD JF. La phénomenologie. Paris: PUF, 1932.

MAFFRE J-J. A vida na Grécia Clássica. Rio de Janeiro: Zahar, 1989.

MARCUSE H. Razão e revolução. Rio de Janeiro: Paz e Terra, 1975. 
MARCUSE H. Eros e civilização. São Paulo: Zahar, 1982.

MARX K. L'idéologie allemande. Paris: Éditions Sociales, 1953.

MERLEAU-PONTY M. Phenomenologie de la perception. Paris: Gallimard, 1945.

MERLEAU-PONTY M. Le visible et l'Invisible. Paris: Gallimard, 1993.

MONOD J. Le hasard et la necessité: essai sur la philosophie naturelle de biologie moderne. Paris: Points, 1970.

MORIN E. Pour sortir du vingtième siècle. Paris: Fernand Nathan, 1981.

NASR S.H. O homem e a natureza. São Pauto: Zahar, 1977.

OLIVENSTEIN C. A vida do toxicômano. Rio de Janeiro: Zahar, 1983.

OLIVENSTEIN C. Destino do toxicômano. São Paulo: Almed, 1985.

OLIVENSTEIN C. Aspects psychodynamiques du développement et du devenir d'un toxicomane. Confrontations psychiatriques 1987; 20(21):93-101.

PESSOA F. Obra poética. Rio de Janeiro: Nova Aguilar, 1997.

PLATÃO. Obras completas. Madrid: Aguilar, 1993.

POPPER KR. O conhecimento objetivo. São Paulo: EDUSP, 1975.

REICH W. A aplicação da Psicanálise à investigação social. Psicanálise, Fatores sócio-politicos, Porto: RES, 1965. 
REICH W. Psicologia de massas do fascismo. Porto: Escorpião, 1974.

SARTRE JP. L'être et le néant. Paris, Gallimard, 1947.

SARTRE JP. Une idée fondamentale de la phénoménologie de Hussert: L'Intentionalité, Critiques Littéraires (Situations, I), Paris: Gallimard 1947

SARTRE JP. Saint Genet comedien et martyr. Paris: Gallimard, 1947.

SARTRE JP. Critica de la razón dialéctica. Buenos Aires: Losada, 1963.

SCIVOLETO S. Manual de medicina da adolescência. Belo Horizonte: Health, 1997.

SECA J-M. L'emprise rituelle des fêtes rave. In: FERRÉOL G. et al. Adolescence et toxicomanie. Paris: Armand Colin, 1999.

SHAH SIA. Islamic Sufism. Nevada/USA, Tractus Books, 2000.

SHAH I. Chercheur de verité. Paris: Albin Michel, 1984.

SHAH I. Os sufis. São Paulo: Pensamento, 1987.

SHAH I. Caravana dos sonhos. Le Courrier du Livre, Paris, 1978

SHAH, Omar A. Un Apprentissage du soufisme. Guy Trédaniel Éditeur: Paris, 2001.

SHÉRER R. Husserl, la philosophie et ses développements. Paris: Hachette, 1979. 
SÓFOCLES. Édipo Rei. Petrópolis: Vozes, 1974.

TIBA I. Puberdade e adolescência. Desenvolvimento biopsicossocial. São Paulo: Ática, 1985.

TIBA I. Anjos caídos. São Paulo: Gente, 1999.

VALLEUR M. ,Debourg, A., Matysiak, J.C.. Vous, vos enfants et la drogue. Paris, Calman Levy, 1990.

VEYNE P. O Império Romano. História da Vida Privada I (organizador), São Paulo: Companhia das Letras, 1990.

DE WAELHENS A. Une phylosophie de l'ambiguité. Paris, 1977.

WESTPHAL MF. - Participação popular e políticas municipais de saúde: o caso de Cotia e Vargem Grande Paulista. [Tese de Livre Docência Faculdade de Saúde Pública da USP] pp. 25-52, 1992.

WESTPHAL MF. O modelo de atenção na perspectiva da saúde integral: a promoção de saúde e a estratégia de "Municipios Saudáveis" - Sanare Rev sobralense políticas públicas; 2(3): 4-9, out/dez 2000. 


\section{ANEXOS}

\section{A instituição "Reino da Garotada"}

\section{Histórico da Entidade}

O "Reino da Garotada" de Poá foi fundado em 30/01/1944, pelo padre holandês Simon Switzar, com o objetivo de atender crianças órfãs elou abandonadas, no sistema de internato. Ao longo dos anos passou por transformaçōes, acompanhando assim as necessidades da comunidade e a evolução na área do trabalho social. Em 1968 a entidade fundou a Aldeia SOS de Poá e o atendimento das crianças passou a ser mais individualizado, em casas-lares e não mais no antigo estilo de orfanato. A partir de 1983 começou a funcionar a Creche, recebendo crianças da comunidade no regime de semi-internato. Em seguida vieram o Centro de Juventude, centrado na área de complementação escolar para a faixa etária de 7 a 13 anos e as Oficinas-Escola, para adolescentes de 14 a 18 anos. $O$ internato deixou de fazer parte do atendimento em 1993, data em que o "Reino" passou a priorizar o trabalho sócio-educativo para crianças e adolescentes de famílias de baixa renda nas três áreas: Creche, Complementação Escolar e Capacitação Profissional.

2. Finalidade

É uma associação civil, sem fins lucrativos, que tem como finalidade prestar assistência, educação e capacitação profissional para crianças, 
adolescentes, jovens e famílias de baixa renda, em situação de risco ou exclusão social, incluindo a formação moral e religiosa.

\section{Quadro de Atendimento}

\begin{tabular}{|l|l|c|}
\hline Setores & Atividades & $\begin{array}{l}\text { No. De Crianças } \\
\text { Previsão p/ 2001 }\end{array}$ \\
\hline $\begin{array}{l}\text { Creche (integral) } \\
\text { (0 a } 6 \text { anos) }\end{array}$ & Berçário, Matemal, Jardim e Pré-Escola. & 300 \\
\hline $\begin{array}{l}\text { Centro de Juventude (1/2 } \\
\text { período) } \\
\text { (7 a 13 anos) } \\
\text { (Complementação Escolar) }\end{array}$ & $\begin{array}{l}\text { Orientação de Estudos, Recreação, } \\
\text { Esportes e Lazer, Música, Dança, Artes } \\
\text { Cênicas, Informática, Expressão Plástica, } \\
\text { Literatura. }\end{array}$ & 250 \\
\hline $\begin{array}{l}\text { Oficina Escola (1/2 periodo) } \\
\text { (14 anos a adultos) } \\
\text { (capacitação profissional e } \\
\text { complementação escolar) }\end{array}$ & $\begin{array}{l}\text { Ajustagem Mecânica, Corte e Costura, } \\
\text { Marcenaria, Instalaçōes Elétricas, }\end{array}$ & 260 \\
\hline TOTAL & Móveis. & $\mathbf{8 0 0}$ \\
\hline
\end{tabular}

Outros Projetos (Adultos)

\begin{tabular}{|l|l|c|}
\hline Projeto & Carga Horária & Previsão de Atendimento p/ 2003 \\
\hline $\begin{array}{l}\text { Projeto Estruturação Familiar e } \\
\text { Geração de Renda }\end{array}$ & 8 horas/semana & 60 \\
\hline Total & & (2 grupos em 2 semestres) \\
\hline
\end{tabular}

3. Representante Legal

Nome: José Massa (Presidente)

Telefone:(11) 4638- $2466 / 3444$

4. Técnico Responsável e Coordenadora Pedagógica 
Nome: Rosely Lopes Lordello

Telefone: (11) 4638-2466 / 3444

Formação Profissional: Psicologia

\section{Gestão e Implementacão}

(Programa de trabalho realizado em Poá com a descrição de seus conteúdos)

\subsection{Preparação do trabalho}

São realizadas reuniōes preparatórias com a equipe de professores + a coordenadora do "Reino" onde se discute tanto as idéias para a implementação do PAP e do trabalho com familias em termos de conteúdo, forma e em acordo com nossa intenção de ajudar a comunidade local, jovens e adultos: 1) no trato das situações referentes ao uso e abuso de substâncias psicoativas pelos individuos que a compōe; 2) no trabalho com as próprias familias, via suporte às relaçōes familiares, oficinas profissionalizantes oferecidas pelo "Reino", incentivo à geração de renda.

Foram estabelecidos os critérios de seleção dos alunos que participam do PAP, respeitando, em primeiro lugar, o julgamento dos professores e coordenação quanto às necessidades locais, tal como eles as percebiam: são escolhidos, a cada vez, 30 adolescentes; cada professor sugere certos alunos obedecendo 2 critérios básicos: os mais necessitados desse tipo de trabalho (por sua proximidade com o mundo das drogas, seu uso experimental ou ocasional, seja porque há um histórico familiar - uso de álcool ou outras substâncias por seus pais, ou seus irmãos já participam do circuito das drogas...); e os que mais poderiam aproveita-lo segundo seu julgamento. 
No caso das famílias, o critério básico, além de terem seus filhos na instituição, é o seu grau de dificuldade econômica.

\subsection{Desenho básico das oficinas com familias e adolescentes}

- Certas oficinas são iniciadas com um "quebra gelo" (exercício de respiração/andar pela sala, mexer o corpo/dançar, cantar...)

- Em seguida pede-se que as pessoas lembrem da "intenção" que temos em estar ali - aplicadores e as pessoas do grupo em questão (adolescentes/pais/professores). Declaramos então essa intenção da forma mais clara possivel nas primeiras reuniōes e nas posteriores pedimos que cada um recorde-se de sua intenção.

- Descrição do tema a ser tratado naquela oficina

- Toda oficina traz um conto de ensinamento escolhido em função do tema, do momento e das pessoas.

Além disso, toda oficina é precedida de um planejamento onde se decidem o conteúdo e instrumentos a serem utilizados sendo que um Relatório sucede cada oficina realizada tentando dar conta do que ocorreu, pontos fortes e pontos fracos a serem revisados.

2.3 - Descrição de cada oficina do PAP com adolescentes

1 - Apresentação do trabalho:

- Objetivos e metas, cronograma de atividades, e menção de alguns recursos usados nas atividades.

- Estabelecimento de um "inventário oral" das coisas que eles gostam: músicas, letras das músicas (listar duas ou três delas) filmes, tipo de programas,

1.1 - Identidade do Adolescente:

- Buscar um reconhecimento da fase de desenvolvimento em que se situa o adolescente, impulsos, desejos, influência do grupo de 
amigos, busca de novidades

2/3 - Amor e Sexualidade:

- Da irrupção de um impulso natural muito forte, diferenças entre sua manifestação nos homens e nas mulheres, o papel da cultura, relação entre banalização do sexo/do corpo, sua proibição, e a fruição desse impulso em harmonia com certos valores que o jovem pode adotar por si mesmo/para si mesmo.

- DSTs/AIDS - informação e formas de prevenção.

4/5 - Súbstâncias Psicoativas:

- Fornecer informação precisa e atualizada sobre drogas/principais substâncias utilizadas, características, efeitos, conseqüências. Aqui, atençāo especial é dada à discussão em torno do álcool e da maconha, esta em sua apresentação atual com seu princípio ativo aumentado (as duas, algumas vezes, percebidas pelos adolescentes como substâncias sem maiores conseqüências, em relação às quais mantém-se o controle sem problemas...). O "ecstasy" também merece atenção por sua popularização crescente conjugada com sua aparente inocuidade.

6 - Projeto de Vida Profissional - Levantamento sobre os recursos pessoais/talentos/competências existentes e/ou a serem desenvolvidas; projeto para o futuro (levando em conta e, ao mesmo tempo, a despeito das dificuldades atuais)

7 - Inventário das condições necessárias à realização do projeto de cada um; conciliação entre sonho e realidade; importância do 'foco; desdobramentos possiveis dessa realização em termos individuais, familiares, sociais.

8 - Avaliação Final. 


\section{Intervenções realizadas no colégio Lycée Pasteur}

Este constitui um pequeno histórico das açōes, ainda que esparsas, desenvolvidas no Lycée, em 2001 e 2002, com as sugestōes para a sua seqüência. Iniciamos explicando a filosofia de trabalho que norteia nossa ação nesse tipo de realidade e sintetizamos a seguir seus principais pontos:

1. O PAP define-se como um programa de trabalho voltado para a prevenção ao uso de substâncias lícitas e ilícitas pelos adolescentes, programa esse que deveria ser assumido por toda a comunidade escolar. O PAP constitui-se de um conjunto de ações planejadas em acordo com as características específicas da instituição onde será implantado.

2. Considerando-se a escola como um lugar privilegiado no tratamento dessa questão, a estratégia de operação do PAP prevê o envolvimento de alunos, pais e professores/direção, de modo a conseguir uma "unidade de ação" em torno da delicada situação de prevenção.

3. Construção de vinculos de respeito e confiança com os adolescentes uma atividade preventiva envolvendo grupos adolescentes, que pretende atingir certo grau de eficácia, exige clareza e firmeza de propósitos associados a um grande cuidado com a forma de aproximação escolhida - postura, linguagem, aspectos lúdicos, etc..

4. Esses vínculos de respeito e confiança são construídos pouco a pouco, ao longo de um conjunto de intervenções, através de um relacionamento mútuo sincero e, portanto, desprovido de preconceitos;

5. Importa ouvir o adolescente e reconhecer seu estatuto de pessoa que tem algo a expressar sobre o assunto, com os recursos próprios à sua idade, com maior ou menor grau de elaboração, independentemente de sua posição em relação às drogas lícitas e ilícitas - de não usuário, usuário recreativo, uso regular ou mesmo abuso;

6. Induzir à reflexāo e ao auto-questionamento sobre os temas propostos, e dai propiciar escolhas mais e mais conscientes e próximas de uma vida sadia - em lugar de tentar impingir aos adolescentes, pelo medo ou ameaças, o que eles devem e o que não devem fazer... 
Açōes de prevenção ao uso e abuso de drogas no Colégio Lycée Pasteur de São Paulo (detalhamento e sugestões para o futuro)

Em acordo com as decisōes tomadas pela Comissão de trabalho sobre o tema, foram realizadas algumas reuniōes de responsabilidade do Lycée, orientadas por nós. As primeiras envolvendo professores do primário (8 deles, ao final, mostrando-se interessados em desenvolver um trabalho especifico com as crianças); e as seguintes com os "pais delegados" (21 pessoas presentes). Outras reuniões aconteceram entre os membros da

Comissão e os professores do secundário (quando 12 entre eles mostraram-se com interesse em "fazer algo" com os alunos*).

Em sintese, em cada uma das reuniōes foram abordados alguns temas como segue:

1. referentes aos diferentes tipos de drogas licitas e ilicitas

2. sobre os efeitos nocivos mas também sobre o prazer encontrado (ponto que não deve passar em silêncio)

3. de pesquisas realizadas no Brasil e na França acerca da opinião dos adolescentes sobre o tema

4. sobre a distinçāo entre uso, abuso e dependência e os modelos de prevenção

Foi enfatizada a relação existente entre, experimentação elou uso e abuso de substâncias por adolescentes, e a situação do "clima familiar", a "pressão dos pares", etc,. Além disso, foram tratados os aspectos naturalmente presentes na adolescência, como a necessidade da constituição de uma "identidade própria", a irrupção da "sexualidade", a relação muitas vezes conflituosa com a autoridade e com a Lei... 
Através de dinâmicas de grupo, junto aos professores do primário foi usado um exercício de "contraponto", descrito no cap. Therapeuem, para o exame do papel dos pré conceitos, que impregnam o tema drogas (que implica posturas do tipo "o mal são os outros"/"se existem problemas eles tem a ver com os filhos dos outros").

No grupo dos pais delegados solicitou-se uma reflexão em subgrupos a partir da questão: "o que leva um adolescente a se aproximar das drogas e continuar a usá-las?" Vale a pena listar os principais pontos de vista elaborados pois eles acabaram tocando nas situações que realmente merecem atenção:

Grupo 1) Desconhecimento dos efeitos - Curiosidade - Proibição/Repressão em relação às droga facilita a curiosidade/vontade de aproximação - A familia considerada como fator importante na influência positiva e/ou negativa : rejeição e falta de apoio se o adolescente chega a experimentar.

Grupo 2) Curiosidade + prazer - Procura de prazer - Identificação com o grupo de pares - Imagem negativa / Imagem positiva de si mesmo Problemas familiares

Grupo 3) Pressão do grupo de pares $\rightarrow$ fenômeno social - Prazer inicial

Grupo 4) Caráter e personalidade mais ou menos indefinidos - silêncio sobre o tema no convivio familiar e/ou institucional escolar (Obs.: os temas que se repetiram nos grupos subsequentes ao primeiro não foram novamente registrados.)

(PS- Palavras de mães delegadas: 1). Mexendo nesse assunto de drogas estaremos trabalhando a estrutura da escola, beneficiando o consenso de linguagem, de objetivos, prioridades, meios e diálogo sobre os temas necessários e de interesse à prevenção do uso de drogas... 
2) Até uma certa idade, alguns professores são considerados como autoridade inquestionável e amedrontadora, e depois são desconsiderados, deixados de lado pelos alunos, 'Como um professor pode assim estabelecer diálogo, reflexão e vínculo afetivo com seus alunos, servindo de modelo de identificação - na medida que Ihe cabe - na formação do adolescente ?')

Ao final, apesar dos participantes desses encontros terem integrado uma série de informações e novos modos de refletir sobre a situação da prevenção às drogas no Lycée, houve uma demanda clara acerca dos passos a seguir no futuro próximo. Nas palavras de um dos professores: "e agora o que faremos?"

\section{Conclusōes derivadas do trabalho até aqui realizado no Lycée}

1) tendo em conta a urgência da situação de prevenção às drogas junto aos adolescentes em geral, (que tem apresentado crescentes indices de experimentação/uso e abuso, em idades cada vez menores nos últimos anos)

2) considerando, como diz o pesquisador I. Tiba, que não se pode saber, a priori, quais entre os adolescentes que "só" chegarão a experimentar uma ou outra droga tornar-se-ão dependentes (por menor que seja essa possibilidade);

3) sabendo que o jovem dependente, em maior ou menor grau, como indica a psicanalista francesa Françoise Dolto, mesmo quando consegue curarse carregará uma ou outra seqüela, em termos de seu "funcionamento" em sociedade, para o resto da vida;

4) em acordo com as indicações da OMS (Organização Mundial da Saúde), que propōe o uso dos espaços educacionais, além de outros contextos sociais além daquele propriamente familiar, no esforço preventivo;

5) integrando o debate filosófico/educacional, presente no Lycée, sobre os papeis relativos da escola/professor na formação dos alunos, e aquele cabivel aos pais; 
Levando em conta tudo isso, haveria uma necessidade urgente de estabelecimento de canais de diálogo específicos sobre os assuntos relacionados às drogas, entre os diferentes subsistemas do Lycée Diretoria, Docentes, Pais e Alunos. Tratariamos assim, não somente de fazer alguma coisa, mas de introduzir uma verdadeira filosofia de trabalho sobre o tema, que seria gerida de modo eficaz por pais, alunos e professores/Diretoria.

Até aqui, tem havido um esforço especial da direção em discutir o assunto mas fato é que as açōes tem acontecido de modo aleatório mesmo pensando nas intervençōes externas - sem seguir uma política de ação orientada. Isso tem produzido atitudes isoladas, sem conexão entre si, na base de campanhas contra o cigarro, por exemplo, cujas mensagens em cartazes encontram pouca ressonância entre os alunos; ou através de intervençōes de professores de SVT/Biologia, por exemplo, que introduzem o tema em aula e realizam um bom trabalho cujos resultados, infelizmente, acabam ficando restritos às salas trabalhadas.

É forçoso concluir dos comentários acima que é fundamental instaurar um "programa de ação" em torno da situação de prevenção às drogas numa escola, planificado a longo prazo. Pouco a pouco, com paciência, mas ao mesmo tempo com firmeza de propósito.

\section{E como pode ser esse programa?}

Reportando-nos, mais uma vez, às considerações do grupo técnico da OMS em torno do assunto, e à experiència de implantação de programas semelhantes em outras instituições, a sugestão mais adequada parece residir na formação dos chamados "multiplicadores". 
Por um lado, trata-se de preparar o quadro docente para que os professores possam sentir-se minimamente em condiçōes de tratar do tema junto aos seus alunos, das mais variadas maneiras, nas diversas matérias. A título de exemplo: em Matemática, lidando com estatísticas das pesquisas existentes; em História tratando da função ritual associada ao uso de drogas em povos primitivos e comparando tal situação com a mercantilização das substâncias psicoativas no mundo contemporâneo, em SVT/Biologia abordando os efeitos das drogas no cérebro ou lidando com temas associados; em Espanhol ou Inglês lendo textos que tratam do tema ou examinando o modo de tratamento dessas questões nesses paises; etc..

Há muitas possibilidades a serem exploradas, que dependem de disponibilidade de tempo, é certo, mas também de certa dose de engajamento - da instituição, pais e professores - numa mesma linha de trabalho.

Por outro lado, a mesma "formação" pode ser estendida aos pais de maneira a tornar-lhes acessivel um conjunto de informações que os ajudem a "melhor ajudar seus filhos" nesse campo especifico.

\section{E o que seria essa "formação"?}

Óbvio que não se trata de formar especialistas, mas sim possibilitar que as pessoas, munidas de um conjunto de informaçōes e de técnicas para sua passagem, sintam-se mais à vontade para entrar no tema, discuti-lo, perceber situações que mereçam um maior cuidado, saber encaminhá-las, etc..

Na seqüência dessas oficinas se trata de elaborar estratégias especificas para o tratamento da questão das drogas em cada faixa etária, levando em conta a particularidade de cada matéria e um mapeamento da 
situação existente no Lycée que, durante o trabalho das oficinas, pode ser estabelecido.

Estas idéias pretendem contribuir para a discussão de uma situação que, na verdade, já está acontecendo, às vezes implicitamente, como se vê a respeito do rumor acerca do consumo de maconha na escola - fala-se! daí a ser verdade, só mesmo tornando explícita a discussão, integrando nela os alunos, principais interessados, de modo harmonioso, num esforço contínuo que deixe claro, para toda a comunidade escolar, a importância atribuída ao tema do uso e abuso de substâncias lícitas e ilicitas.

A partir desse ponto, a atuação de um dos membros do Girassol foi incorporada à "Comissão de Saúde e Cidadania" da escola que se reúne periodicamente para estudar as formas de intervenção mais apropriadas. $O$ balanço, entretanto, dessas ações permanece negativo, por assim dizer, na medida em que não houve o estabelecimento de uma continuidade nos trabalhos que propicie uma conexão mais forte com alunos/pais e professores/direção.

*Alguns dentre eles, na última reunião com professores do primário e secundário, manifestaram o desejo de obterem uma orientação mais clara sobre 0 assunto, pois tem dificuldade em tratar o tema drogas ou por desconhecê-lo totalmente, ou por sentirem pouca receptividade dos alunos (ültimo-anistas).

Anexo - Contos de Ensinamento 
"Era uma vez um homem que se achava muito sem sorte. Parece que tudo o que fazia dava errado. Muitas coisas ruins aconteciam a ele sem que ele soubesse o porquê. Sempre que se encontrava com alguém, aproveitava para falar de sua falta de sorte. Com o tempo as pessoas começaram a não querer se encontrar com ele,para não ter que ouvir aquelas histórias de como as coisas não davam certo, e isso fez com que se sentisse muito só.

Um dia , sentindo-se triste e sozinho, disse para si mesmo: "Tenho que fazer alguma coisa". E teve uma idéia:

"Já sei o que fazer! Vou me encontrar com Deus! Se Deus me fez assim, sem sorte, Ele pode mudar a minha vida e me tomar um homem de sorte".

Preparou as suas coisas e, numa manhã, partiu em viagem.Andou por dias e meses e, finalmente, chegou a uma gigantesca floresta. "Esse deve ser o lugar onde vive Deus", disse o homem muito sério para si mesmo.

De repente ouviu um grito:"Socorro! Ajude-me!" Ficou muito assustado, olhou a sua volta e viu que à sua frente havia um lobo.Mas esse não parecia um lobo comum, estava todo sem pelos e parecia muito doente.

"O que você quer?",perguntou o homem.

"Meu Deus, estou tão doente. Não tenho me sentido bem por meses e meses. Por favor, me ajude".

"Você precisa de ajuda? Eu é que preciso de ajuda .Tenho estado sem sorte toda a minha vida. Estou indo me encontrar com Deus ao invés de ficar sentado me lamentando.

"Ah! Isso é muito corajoso. Mas eu não posso caminhar. Por favor, se você encontrar com Deus,poderia perguntar-Lhe o que posso fazer para melhorar a minha situação?"

O homem concordou com indiferença e foi embora pela floresta. De repente ouviu um gemido: "Ahhhh!" E viu uma árvore que estava toda quebrada, muito feia, com as folhas ressecadas. "Socorro!" gritava a árvore.

"Estou farto dessas pessoas que vivem pedindo ajuda. E você agora, o que quer?" disse o homem.

"Estou me sentindo doente por muitas semanas. Por favor me ajude". "Por que eu deveria te ajudar? O que você fez por mim? Ao invés de 
se lamentar, faça como eu. Vou me encontrar com Deus". A árvore fraca disse: "Eu não posso me mover. Por favor, peça ao Criador para me ajudar".

O homem disse que iria pensar a respeito e foi embora depressa. Chegou então num lindo campo de flores onde havia uma linda casinha. "Ah! Aquela deve ser a casa do Criador" pensou o homem e correu até ela.

Quando lá chegou, viu uma linda moça sentada na varanda. Ela the deu as boas vindas e the ofereceu chá e bolo. E foi tão bondosa que ele ficou ali falando com ela por um longo tempo. Pela primeira vez na vida teve a oportunidade de contar todos os seus problemas a alguém e nem reparou que a noite havia passado. Quando resolveu seguir o seu caminho, a moça the disse: "Olha, eu tenho uma vida boa aqui mas, às vezes, me sinto um pouco sozinha.

Talvez você possa perguntar a Deus se Ele tem algum conselho para me dar". O homem concordou.

Ele andou mais depressa do que antes até que chegou ao fim do mundo. Lá não havia nada, até as cores da paisagem haviam desaparecido. Neste momento, o homem se sentiu inseguro pois não sabia como falar com Deus. E se sentou para pensar sobre isso. De repente ele escutou uma voz que the disse: "Bem vindo". O homem ficou surpreso e disse: "Você é o Criador?" A voz disse: "As pessoas me chamam por muitos nomes, mas estou certo que não foi por isso que você veio me ver". O homem então começou a sentir que seu coração se abria e que podia dizer e sentir o que quisesse que aquela voz o ajudaria. Ele ficou por muito tempo falando com aquela voz até que percebeu o que ele tinha que fazer. E foi embora $e$ correu tão rápido quanto pôde, direto para a casa da moça.

"Você falou com Deus?" perguntou a mocinha. "Sim", disse o homem. "E ele disse que eu deveria procurar a minha sorte porque ela está bem à minha frente e que eu deveria ir a seu encontro. É isso que eu vou fazer, encontrar a minha sorte. E Ele falou que você está sofrendo porque está sozinha, que você deve buscar uma companhia. E se encontrar alguém, vai viver feliz por muito tempo". 
A moça envergonhada olhou para o homem e disse: "Você gostaria de ficar aqui comigo?" E o homem respondeu: "Eu? Ficar com você? Eu estou procurando a minha sorte, não posso ficar aqui comendo e conversando com você. Você deve procurar outra pessoa. Tchau!"

O homem partiu correndo, olhando para todos os lados procurando a sua sorte até que chegou perto da árvore, que perguntou: "Ah! É você! Você encontrou o Criador? "O homem respondeu impaciente: "Sim, Ele falou que você tem alguma coisa presa nas suas raizes. É uma caixa cheia de ouro, envenénando as suas raizes. O que você deve fazer é encontrar alguém que tire essa caixa daí e você ficará boa de novo". A árvore falou: "Por favor, você poderia tirar essa caixa para mim? Eu não quero tesouro, você pode ficar com ele". O homem respondeu: "Eu não posso. Por que você é tão egoísta? Você quer fazer perder o meu tempo? Já dei a mensagem, agora trate de encontrar alguém para fazer isso".

Foi embora e deixou a árvore. Sempre olhava em todas as direções, procurando a sua sorte. $E$ ia correndo tão depressa que tropeçou no lobo e viu que este estava mais doente do que nunca. Com um grande esforço, $o$ lobo olhou para o homem dizendo : "Oh, espero que você tenha encontrado Deus, porque eu não tenho mais muito tempo de vida. Ele falou alguma coisa sobre mim?" O homem disse que sim:"O Criador disse que o seu problema é fome. Disse que você deve esperar aqui até que a criatura mais boba e distraida cruze o seu caminho e então você a come e mata a sua fome".

O lobo olhou para ele com o último sinal de vida em seus olhos, reuniu suas últimas forças, pulou sobre o homem e o comeu.

Este foi o fim do homem sem sorte. Poderia ter sido bem diferente, você não acha?"

\section{A Viagem de Minai}


Mohsin Minai não estava contente com sua sorte, com a vida banal que levava em sua cidade natal como aprendiz de ourives. Um dia ele decidiu partir em busca de fortuna.

Dirigiu-se com um passo tranqüilo em direção ao grande portal da cidade, bastante decidido a não deixar passar sua chance. Estava saindo da cidade, quando um homem que ele mal conhecia chamou-o:

"Mohsin, se você quiser um emprego de ourives, eu conheço alguém que procura por um profissional competente.

- Não, muito obrigado, disse Mohsin: eu abandonei essa vida; aspiro a um destino melhor!"

O que Mohsin não sabia é que, se não tivesse declinado dessa oferta, ele teria se tornado rapidamente um célebre ourives, e um artista reverenciado, pois tal seria a consequeencia da situação que the propunham, cujo passo inicial ele se recusara a aceitar.

Na realidade, esse encontro havia servido para atiçar ainda mais o desejo de seguir seu destino. "Se não tivesse empreendido essa viagem, disse a si mesmo, se tivesse permanecido na pequena loja do ourives, no bazar, eu não teria tido esta possibilidade de tomar-me um mestre ourives antes que se passassem muitos anos. $\dot{E}$ verdade, a sorte sorri aos viajantes!"

Ele seguiu seu caminho. Estava andando já há alguns dias, quando um desconhecido o abordou:

"Qual é tua profissão?

Sou um mestre ourives", respondeu Mohsin, ao mesmo tempo em que imaginava: "De qualquer modo, se eu tivesse permanecido em minha cidade natal, é certo que teria já me tornado um mestre ourives. Por que deveria apresentar-me então como um simples aprendiz?"

O desconhecido disse-lhe:

"Minha irmã vai se casar e eu gostaria de oferecer-lhe uma jóia, uma peça única. Você aceitaria esse encargo? Eu te forneceria todos os materiais e instrumentos necessários.

Sem dúvida!" disse Mohsin. 
Ele se dirigiu para a cidade mais próxima e criou para a irmã do desconhecido um magnifico bracelete esmaltado.

Depois de terminado o trabalho, disse a si mesmo:

"Enfim, tomei-me um homem importante: ganho dinheiro, meu talento é reconhecido, tenho uma boa imagem aos olhos das pessoas, e isso é só o começo."

Com o dinheiro do bracelete, sua primeira obra por encomenda enquanto artista independente, ele comprou uma loja pois estava decidido a permanecer por algum tempo naquele lugar.

Pouco tempo depois, alguém entrou em sua loja e lhe disse:

"Sou um ourives, procuro um lugar propicio para me instalar e gostaria de comprar tua loja."

Ofereceu então a Mohsin Minai uma quantidade de dinheiro tão grande por sua loja e sua boa vontade, que a transação foi rapidamente concluída. E Minai pôs-se a caminho novamente.

Fazia já um dia ou dois que estava andando, quando bandidos o atacaram, roubaram sua fortuna e o abandonaram na beira da estrada depois de tê-lo espancado.

O que Minai não podia saber, é que se tivesse permanecido na cidade ele se encontraria numa situação muito pior: com efeito, nesse mesmo dia a loja que havia vendido tinha sido engolida por um terremoto, e seu sucessor estava morto.

E ele permaneceu ali na beira da estrada, prostrado, lamentando-se por sua sorte, deplorando sua inaptidão em perseverar, arrependendo-se por ter vendido sua loja por cupidez.

Um homem caridoso que por ali passava percebeu o ourives azarado, e dele se acercou.

"Venha até minha casa, disse ele, eu o ajudarei."

Minai instalou-se na casa de seu novo amigo, esperando que suas feridas sarassem.

"Tenho um pequeno trabalho para você, no jardim", disse-lhe um dia seu hospedeiro. Minai aceitou, e três anos se passaram desse modo, pois agora 
tinha medo de viagens, temia que o azar o perseguisse, que a infelicidade o tomasse. Ao mesmo tempo, felicitava a si mesmo por sua humildade (afinal, não tinha ele sido capaz de por um freio em suas ambições?) e por sua aptidão em assumir esse modesto trabalho de jardineiro, ele, um mestre artesão. Considerava-se como particularmente virtuoso: estava pagando sua divida para com seu salvador, servindo-o, em retomo da imediata compaixão que este havia demonstrado a um vagabundo sem nenhum dinheiro.

O que Minai não sabia, é que se tivesse permanecido ali, na beira da estrada, algo completamente diferente teria acontecido.

Os ladrões, com efeito, não tardaram a brigar entre si, depois de perceber que o azar os havia tomado muitas vezes depois do roubo de Mohsin. Ao final, o chefe teminou sendo morto pelo segundo homem do bando, e este resolveu devolver todo o dinheiro roubado de Mohsin, e mais ainda. Foi então colocar o ouro roubado no lugar onde ele e seus cúmplices tinham deixado Mohsim semi morto, com o objetivo de afastar a "maldição".

Quando havia completado mil dias de trabalho no jardim de seu protetor, Mohsin Minai pediu-lhe permissão para partir dirigindo-se para a cidade mais próxima. Encontrou nesse lugar um emprego na loja de um ourives, como aprendiz. Depois disso, foi trabalhar com um joalheiro, como simples artesão, e terminou como ourives chefe.

"Agora, disse a si mesmo, eu reencontrei meu caminho, ocupo a posição na qual deveria estar se não tivesse tido essas idéias de grandeza $e$ tivesse tomado a decisão de viajar."

Mas, o que ele não sabia, é que suas produções imaginárias a respeito de sua humildade, e a crença vã que os eventos de sua vida formavam um todo coerente, constituiam um grande obstáculo a seu progresso real.

Quando, depois de uma situação confusa, ele foi preso e julgado culpado por desvio de fundos, Mohsin começou a pensar de uma outra maneira: 
"Se ao menos eu tivesse ficado lá onde vivia, as coisas teriam corrido melhor para mim! Mas os infortunios que nos assaltam não passam de provas. É preciso que eu seja paciente no infortúnio."

O que ele não percebia, o que ele não chegou jamais a compreender, é que os diversos eventos de uma vida fazem parte de encadeamentos de causas e efeitos distintos. Qualquer pessoa que tenta agrupar todas as cadeias de eventos num só fluxo, que tenta fazer de todas as histórias que compõem uma vida uma só e única e longa história; qualquer pessoa que se vangloria ao erigir como principio estar cumprindo um destino único, deverá defrontar-se, como conseqüência dessas atitudes, com situações que não serão o "teste" de sua humildade e de sua paciência, mas o pagamento por sua estupidez. Aqueles que acreditam estar sempre submetidos a um teste quando recebem o salário derivado de seus atos, sofrem da doença do orgulho. Esse orgulho os impede até mesmo de imaginar que eles possam colher, num momento ou outro de sua vida, exatamente o que semearam.

Pão, ratos e...

Não permita que os ratos se aproximem do pão,

Não permita que os eruditos se aproximem do trabalho sufi.

Ditado

(Idries Shah - Contes Initiatiques des Soufis) 